
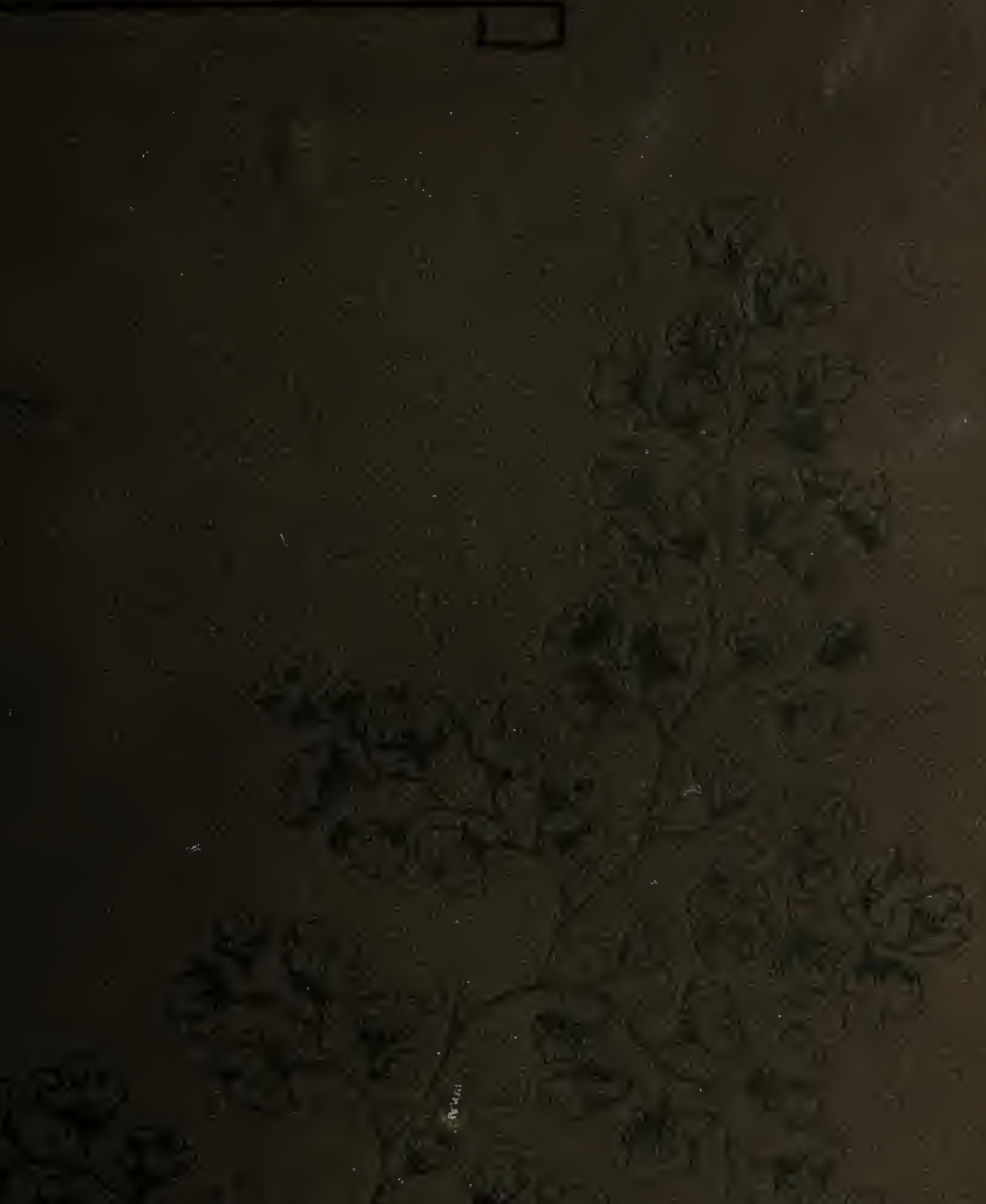

$x^{2} x^{2}=$

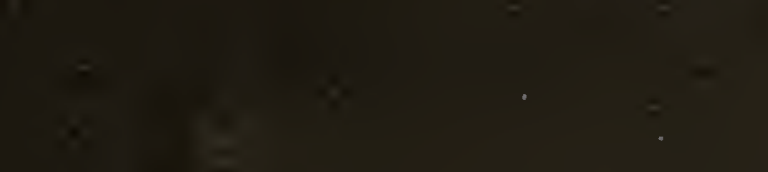




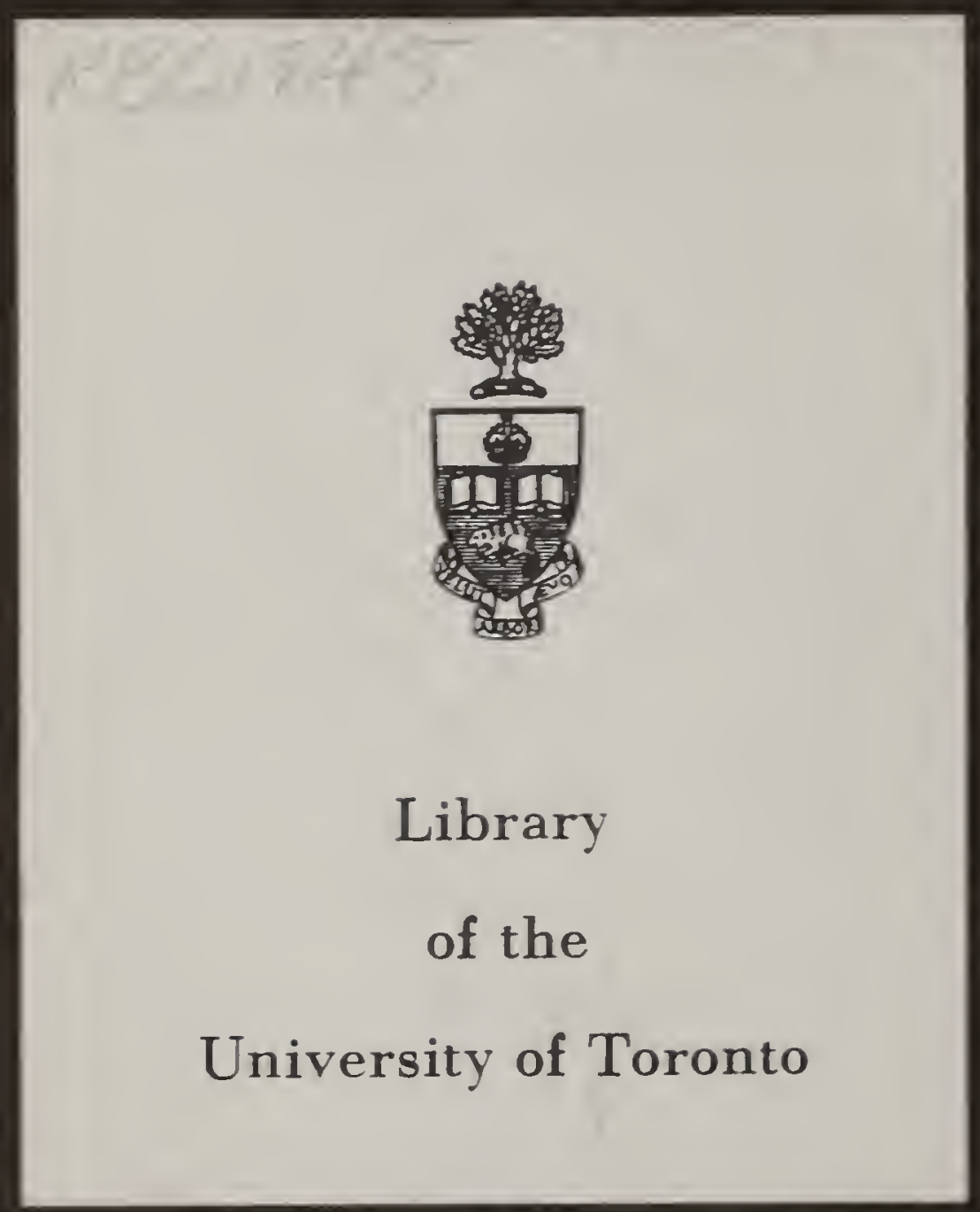


<smiles>CC(C)C(C)C</smiles>

tolst the litit

$3+\therefore 1874$

the car, atcer te : 1848 . 



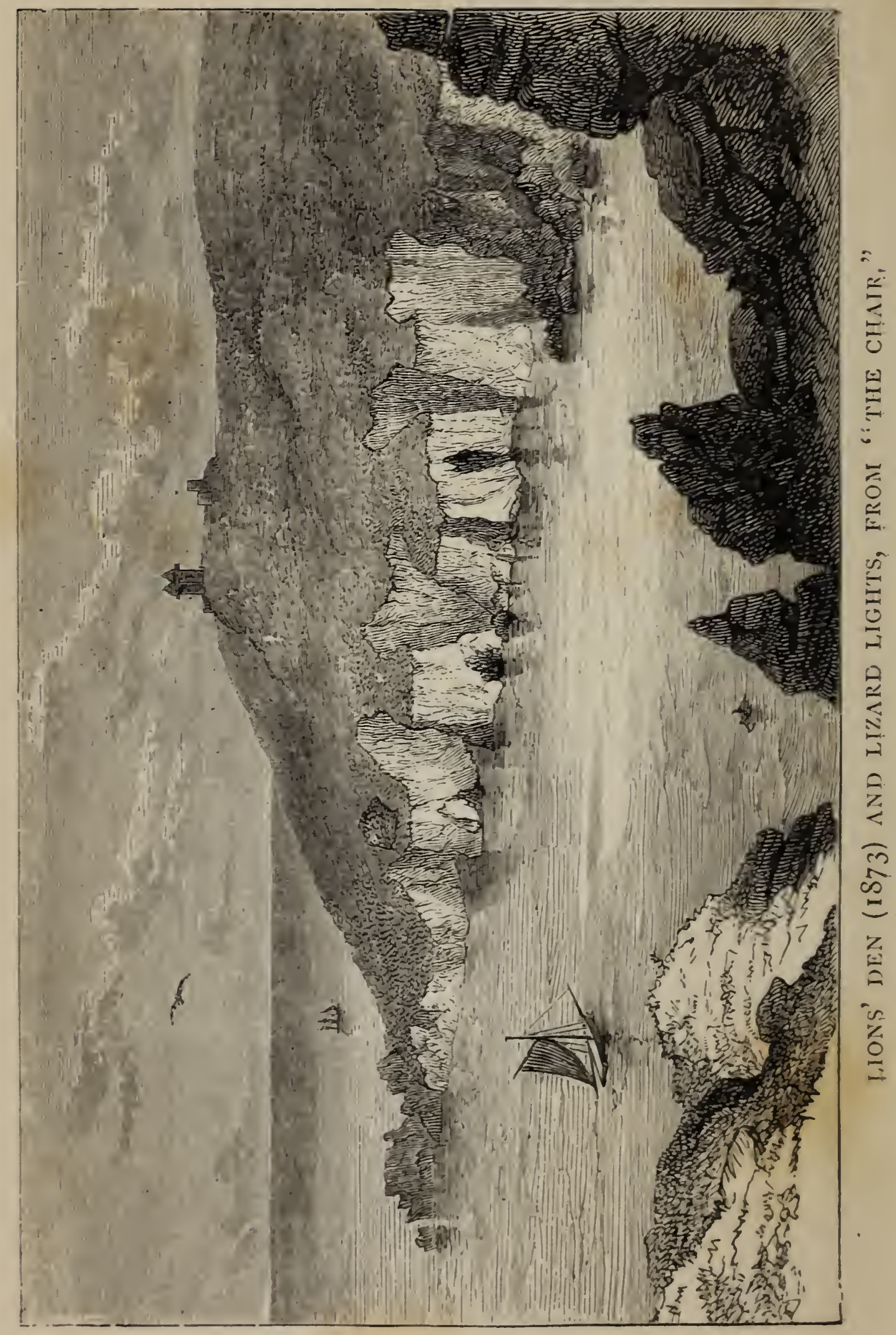




\title{
A WEEK AT THE LIZARD.
}

\author{
BY THE \\ Rev. C. A. JOHNS, B.A., F.L.S.
}

AUTHOR OF

"Botanical Rambles," "Flowers of the Field," "British Birds in their Haunts," \&c.

PUBLISHED UNDER THE DIRECTION OF

THE COMMITTEE OF GENERAL LITERATURE AND EDUCATION, APPOINTED BY THE SOCIETY FOR PROMOTIYG CHRISTIAN KNOWLEDGE.

\section{LONDON :}

SOCIETY FOR PROMOTING CHRISTIAN KNOWLEDGE, NORTHUMBERLAND AVENUE, CHARING CROSS, W.C.;

43, QUEEN VICTORIA STREET, E.C. ; 48, picCAdILly, W.;

AND 135 , NORTH STREET, BRIGHTON.

NEW York : E. \& T. B. YouxG \& Co.

[1881?] 



\section{CONTENTS,}

INTRODUCTION.

Routes to the Lizard-Omnibuses-Postal arrangementsHotels and Lodgings-Guides-Excursions _... page ix

\section{CHAPTER I.}

Character of the District-Fertility of Hornblende Rock-Lizard Lights-Bumble-Fishing with Fly-Lions' Den - Househole Bay-Fishing for Launces-Pen OlverBelidden Cove-Bilbao Electric Cable-Beast PointSignal Station - Hot Point - Lizard Cove - Pilchard Fishery-Landewednack Church and Cross-Peculiar Customs

\section{CHAPTER II.}

Most southerly point in England-Wreck on the CrenvalPolpeer Cove and Caves-Pistol Meadow-Lizard Head - Caerthillian - Kynance Cove - The Kitchen - The Bellows-Asparagus Island-Caves-Variable appear-

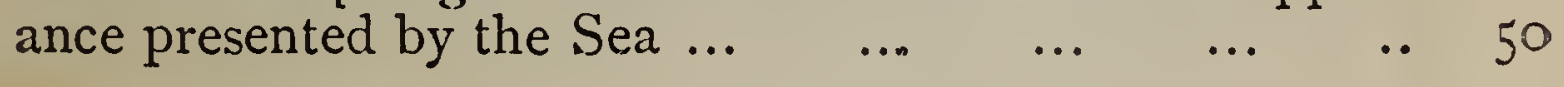

\section{CHAPTER III.}

Effect of Air on Serpentine Rock-Calm near the verge of the Cliff in stormy weather-Sheep-stealers' Cave-The Rill-The Apron-string - Botanical Scramble - The Horse and Horse-pond-Climbing for Gulls' EggsPigeon Hugo-Gue Graze-A Sea-mist-Soap RockSheep-stealers-Botanical Adventure-Steamer running ashore at Gue Graze
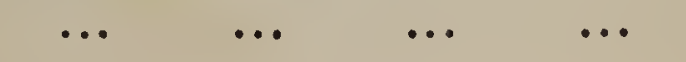


\section{CHAPTER IV.}

The Bali-Ravens' Hugo-Dolor Hugo-The Frying Pan -Cadgwith-Saint Rumon-Conflict between a Man and a Conger-Sunfish-Ynys Head-Poltesco-Kennack Cove-Ground Seine-Sting-fish, Red Mullet, Turbot-The Blackhead ... $\quad \ldots \quad \ldots \quad \ldots$ page Ios

\section{CHAPTER V.}

Pradanack Head-Gull Rock-Mullion Island-Mullion Cove - Copper Mine-Mullion Church-SmugglingPolurrian-Shipwrecks-Gunwalloe Cove and ChurchDollar Mine-Halzaphron Cliffs-Loe Pool-PenroseHelston-Maine Amber Rock-Furry Day

\section{CHAPTER VI.}

A Day at Sea-Fishing for Wrasse-Bream-Pleasures of Sea-fishing-Bathing in Deep Water-Pipe-fish-Minutefish-Swimming Crabs-Gurnards-Pollack-Cuttle-fish -Dog-fish - Daintiness of Crabs - Trammel-net Spillers and Boulters-Sea-sickness-Crabs, Lobsters, and Craw-fish-Loss of Crab-pots-Unexpected prizeBarter with becalmed Vessels-American and French Barks...

\section{APPENDIX I.}

Geological features of the Coast-Granite-Killas-Greenstone-Serpentine-Mica Slate-Diallage Rock-Botany of the District - Loe Pool - Gunwalloe-MullionKynance-Caerthillian-Cadgwith-Poltesco-Kennack 203

\section{APPENDIX II.}

Catalogue of Birds observed in the Lizard District

\section{APPENDIX III.}




\section{LIST .OF ILLUSTRATIONS,}

Lions' Den (I873) and Lizard

Lights from "The Chair."

Frontispiece

The Bumble Rock .. .. II

Lions' Den.. . . . . . . 14

Daws' Hugo-Entrance to Lions'

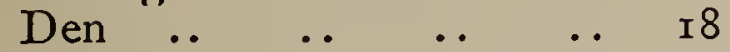

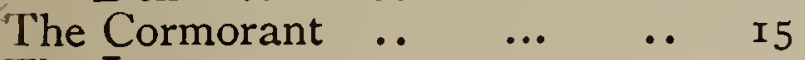

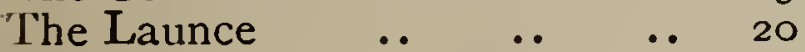

Pen Olver .. $\quad$. $\quad \ldots . \quad \ldots \quad 22$

View of Lizard Lights and Lions'

Den from above Househole 24

Belidden.-Storm at Sea .. 26

Kilkobben Cove .. $\quad$.. $\quad$.. 30

Pilchard $\quad . . \quad \ldots . \quad \ldots \quad$.. 32

View of Landewednack Church and Church-town $\quad . . \quad \ldots \quad 42$

Doorway in Landewednack Church .. $\quad . . \quad$.. ..

Font in Landewednack Church $\ddot{~} \quad 44$

Cave at Polpeer .. $\quad$.. $\quad$.. 54

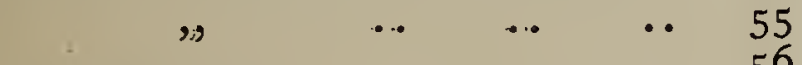

$\begin{array}{lllll}\text { The Kitchen } & \ldots & \ldots & \ldots & 56 \\ & \text {.. } & \text {.. } & \text {. } & 64\end{array}$

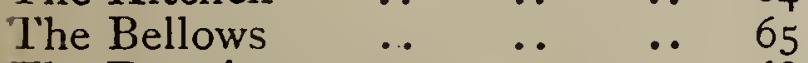

The Drawing-room $\quad$.. $\quad$.. 68

Kynance-from the Rill.. $\quad$.. 86

$\begin{array}{lllll}\text { The Horse .. } & \text {. } & \text {. } & \text {. } & 87\end{array}$

Pigeon Hugo-from the Sea ..

Gue Graze $\quad$. $\quad$. $\quad$.. $\quad$. 92

A Botanical Adventure .. .. IOI

Stranding of the "John McIntire" I05

Dolor Hugo ... .. .. II2

Entrance to the Frying-panseen from within $\quad . . \quad \ldots \quad$ II 3

St. Ruan's Well .. $\quad$.. $\quad$..

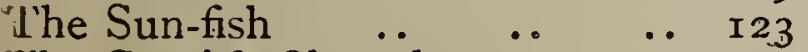

The Cornish Chough .. $\quad$..

'The Lesser Weever .. $\quad$... 128

Pradanack Head .. $\quad$.. $\quad$.. $\quad$ i3 33

Bishop Rock _.. . . $\quad$..

Mullion Gull-rock $\quad$. $\quad$.. $\quad$ I36

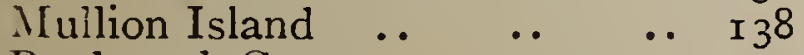

$\begin{array}{llll}\text { Pradanack Cross .. } & \text {.. } & \text {.. } & \text { I. } 13\end{array}$

Gunwalloe Church $\quad$. $\quad$.. $\quad$ I60

Loe Pool-from Degibna Wood 168

Maine-Amber Rock . . . $\quad$ I76

Snake Pipe-fish . . $\quad$.. $\quad . . \quad 185$

Hind Legs of Walking and Swimming-crab
Crab-pots $\quad \ldots$ PAGE

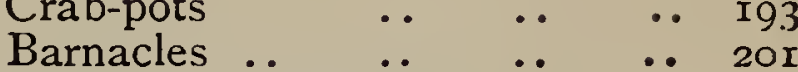

Stunted Ox-eye Daisy $\quad \ldots \quad$. $\quad$. 2 2I 2

Cuscuta Epithymum (Lesser Dodder) $\quad . \quad \ldots \quad \ldots \quad 2 \mathrm{r} 3$

Corrigiola littoralis (Strapwort)

Littorella liscustris (Plaintain Shoreweed) .. $\quad$.. . . 216

Pyrus torminalis (Wild Servicetree) $\quad . \quad$.. $\quad$.. $\quad . .218$

Scilla verna (Vemal Squill) $\quad . . \quad 2$ 219

Convolvulus Soldanella (Sea Bindrueed) .. .. . 22I

Eryngium maritimum ( $\ddot{\text { Sea Holly) }} 222$

Ruppia maritima (Sea Ruppia). 223

Elatina hexandra (Water-zort) 224

Sibthorpia Europæa (Cornish Moneyzuort) .. .. .. 225

Pinguicula lusitanica (Pale Bütterwort) $\quad . \quad \ldots \quad \ldots 226$

Centunculus minimus "(Smäl Chaffreed) .. $\quad . . \quad \ldots 227$

Radiola millegrana (Flax $\ddot{x}$-seed). 227

Genista tinctoria (Dyer's Greenreeed) ... $\quad$.. $\quad \ldots \quad \ldots \quad 229$

Lithospermum officinale (Grey Millet) $\quad . \quad \ldots \quad \quad . \quad 232$

Hioscyamus niger $($ Hen $\ddot{b} a n e) \quad \ldots \quad 233$

Statice binervosa (Sea Lavender), and S. Armeria (SecThrift) .. .. . $\quad 235$

Comarum palustre (Marsh Cinquefoil) $\quad \ldots \quad \ldots \ldots \ldots 236$

Erica tetralix, E. ciliaris, E. vagans, and E. cinerea $\quad . .238$

Lavatera arborea (Tree Mallozw) 240

Anthyllis vulneraria (Lady's -jingers) .. $\quad$.. $\quad$.. $\quad$.. 24 II

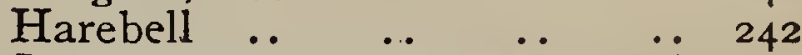

Juncus pygmæus (Pigmy Rush) 244

Exacum filiform (Least Gentianella) ... $\quad . . \quad \ldots \quad$. 245

Sanguisorba officinalis (Burnët) 246

Trefoils $\quad . . \quad \quad \ldots \quad$.. $\quad . .248$

Ruscus aculeatus (B̈itcher's Broom) .. $\quad$.. $\quad$.. 252

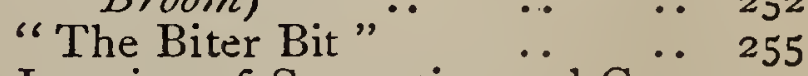

Junction of Serpentine and Granitic Rock .. .. $\quad . . \quad 265$

StoneImplements found at Bochym 267 



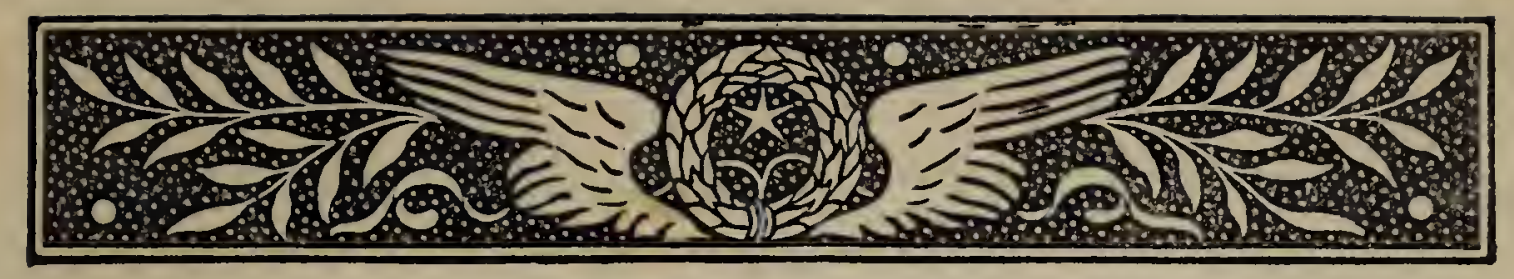

INTRODUCTION,

WHEN this little volume first saw the light, now nearly thirty years ago, the author had little idea that a second edition would ever be called for. That it has survived a second and is again demanded is owing, he well knows, not to its merits, scientific or literary, but to the simple fact that it is a honest and faithful description of little known, and therefore unappreciated, scenery, equalling in beauty any of its kind in England, unique in geological features, and offering to the botanist a greater variety of productions than any district of the same extent in Great Britain.

Published originally as a description of a little-known district, it opened a new scene of exploration to the tourist, and became a "guidebook," and has been quoted again and again as an authority. The introduction of railways, and consequent facilities of locomotion, brought visitors, who required no "New Guide to the Lizard," because time works little change either on rocks or the vegetation of sea-cliffs, and the world are wont to prefer an original production 
-the work, I mean, of an author who describes nothing but what he has seen-to a compilation. The body of the present volume is nearly identical with the first edition. For the additional information the author is indebted to Lord Falmouth, the Rev. P. Vyvyan Robinson, the Rev. E. G. Harvey, Mr. Richard Davey, Mr. F. V. Hill, Mr. G. A. Howitt, Mr. H. Fox, Mr. J. H. Cox, Mr. Cunnack, and to the suggestive remarks of two friends, the Rev. E. L. Berthon and Mr. Cornwall Simeon, who accompanied the author and his son in a ramble round the coast in August, 1873 .

Time, though it takes little effect on rock or cliff, is by no means inactive on modes of transit and hotel accommodations. For the convenience of tourists, therefore, the author has included in the few following pages such information as they may reasonably expect to find in a guide-book, inserted, not to be read but to be referred to as occasion may require.

The cheapest, and in fine weather the pleasantest, mode of reaching Falmouth from the east is by one of the Irish steamers, which leave London on days advertised in the Times, and touch at Southampton and Plymouth, remaining a few hours at each place.

The quickest is by railway.

The transit from Penryn or Falmouth to Helston, which takes about an hour and a half, may be made either by omnibus or a private carriage.

On reaching Helston, travellers will find excellent accommodation at either of the two principal 
hotels, the "Angel " and the "Star." If lodgings have been bespoken at Lizard Town, and the day is not too far spent, they may proceed at once in hired carriages and reach their destination in about two hours.

Every morning, Sundays excepted, from the beginning of May to the end of October, an omnibus, awaiting the arrival of that from Penzance and that from Penryn, leaves Helston at Io A.M., and returns in the afternoon, leaving the Lizard at 4.20 P.M., and meeting at Helston the Penzance and Falmouth omnibus for Penryn Station, in time for the train, which goes as far as Plymouth the same evening.

Throughout the year an omnibus leaves the Lizard for Helston on Wednesday and Saturday at IO A.M., and returns at 5 P.M. There is also, during the season, another omnibus daily, backwards and forwards between the "Angel" hotel, Helston, and Hill's Hotel, Lizard.

The hours of Divine Service at Landewednack Church on Sunday are at I I A.M.. and 6.30 P.M., twice in the day; and on each alternate Sunday once, namely, at 3 P.M. Seats free; the church always open; an offertory at every service. Incumbent, the Rev. Philip Vyvyan Robinson, M.A., who will be found at all times ready to give information or advice to nis temporary parishioners.

The general post comes in at I I A.M., and goes out at I.3O P.M. A messenger calls at the Post Office for telegrams four times a day.

There are two inns, one kept by Mr. James Hill, who has recently provided increased accom- 
modation for visitors, of whom many have come to the Lizard with the intention of spending some time, and have been obliged to return to Helston the same day. Strangers, therefore, are recoinmended to telegraph for rooms, when they will be sure of civility; comfortable lodgings, and a good table, beer and wine included. ${ }^{1}$ A smaller inn is kept by Mr. Lugg.

Besides these inns, there are several houses in which comfortable lodgings are provided, some of which overlook the sea. These are-Mrs. Rowe, Park Braws; Mrs. J. Richards, Lizard Town; Miss Lyne, junior, Beacon House; Mrs. Jeffery, Mr. W. Jose, Mrs. Beer, Mrs. Hooper, Beacon Terrace.

At Kynance Cove, close to the most beautiful scenery, homely but clean and comfortable lodgings, and such refreshments as bread, butter, cheese, tea, and ginger-beer, are provided by Mrs. Thomas and Mrs. Oliver. At Mullion there are two comfortable inns-the "Old" (Miss Mundy), and the "New" (Mrs. Williams). At Cadgwith "The Hotel" is a very comfortable house.

The guides, all perfectly trustworthy, are Benjamin Williams, Francis Jose (who knows the localities of all the rare plants), Richard Roberts, and Joseph Roberts. Boats for rowing, sailing, or fishing are to be had on application to Thomas Stirling, John Johns, Sampson Hill, and James Stevens. I was pleased, in August, IS73, to shake hands with Samson Hill and

1 Carriages for long excursions may be hired here. 
Samuel Stevens, the only two survivors of the "Cornish Giants" who formed my crew on the occasion of my "Day at Sea" in I847, to be described hereafter.

Mr. Cunnack, bookseller, Helston, is thoroughly well acquainted with the botany of the district, and is ready to give information to any naturalist consulting him.

There are in the village several shops for the sale of useful and ornamental objects in polished serpentine and steatite. These are made in the village and sold at moderate prices. Purchasers may rely on the honesty of the vendors, and need have no doubt that any specimens they may choose to take away with them will be carefully packed for carriage.

As the tourist will certainly wish to make some excursions, the feasibility of which depends more or less on the state of the tide, he will do well to recollect that on the day of new and full moon it is high water at the Lizard about 4.45 A.M., getting three-quarters of an hour later every day; also that between low water and high water (flood tide) the current sets for about six hours towards the east, and between high and low water (ebb tide) the same time towards the west.

Fish, under which term I include crabs and lobsters, are rarely to be had without bespeaking them.

In order that the contents of this little volume may justify its title, "A Week at the Lizard," I have divided it into six chapters, and have suggested an excursion for each day in the week. 
But for the convenience of tourists who may not care to bind themselves down to my programme, I will here add hints for the making of various trips which will enable them to take the whole coast in detail.

From Helston, through Penrose, to the Bar returning by way of Carminowe Creek and Degibna-on foot, in any state of the tide.

From Helston to Gunwalloe and back-on foot or by carriage.

From Helston to Gunwalloe, on foot or by carriage; thence proceeding on foot round the coast, by way of Halaphron and Poljew, to Mullion, whither a carriage may be ordered to proceed and meet them, or where they may obtain refreshment and comfortable lodgingsany state of the tide.

Mullion to Mullion Cove, on foot, at low water, in order that the cave may be visited.

Lizard Town to the Lighthouses, inspecting Mr. Hart's studio ; thence proceeding eastward to the Bumble, Lions' Den, Household Cove, and back to Lizard Town-any tide; high water perhaps preferable.

Lizard Town to Pen Olver, Belidden, Beast Point, Hot Point, Lizard Cove, back to Lizard Town through Landewednack - any tide.

Lizard Town to Lizard Cove, thence by boat, examining the caves between that place and the "Frying-pan ;" then land and walk to Cadgwith : there get refreshments at the hotel, and either walk home or return by boat. This excursion may be reversed, but the sea part of the trip should be taken at low water. 
Lizard Town to Polpeer-low water; thence westward to the Lizard Head, Caerthillian, Yellow Cairn, and back to Lizard Town.

Lizard Town to Kynance Cove-low water.

Lizard Town to the Rill Head, and thence along the cliffs to the Horse, Gue Graze, Vellar Head, Pradnack Head, and back to the Lizard across the downs-any tide.

Lizard Town to Mullion Cove; low water about the second or third day afier new or full moon, starting about ten o'clock, or an hour later every day.

This may be done in several ways. Ist. By making at once for the Rill, and following the cliff to Mullion Cove, then proceeding to the Church Town, and walking home across Pradanack Down. 2ndly. By ordering a carriage at Lizard Town to be waiting at Mullion Town till called for, and to proceed on foot round the coast as above. 3rdly. By reversing the route. 4thly. By taking a carriage to Mullion Town, visiting the Cove on foot, and returning by carriage. 5thly. By taking a carriage at Lizard Town and going all the way through Mullion Town to the Cove, and returning by carriage by the same route.

In any case the excursion must be so arranged that Mullion Cove may be visited not less than an hour before low water, or the tourist will miss one of the finest caves on the coast. A large portion of the down between Landewednack and Mullion being flat and destitute of conspicuous land-marks, the tourist will find it useful to notice particularly the position of the 


\section{xvi}

A WEEK AT THE LIZARD.

"Old Windmill," set down in the map. Should he find himself uncertain about his way, he may take his bearings from this, and, by the help of a pocket-compass, make straight for any point of the coast. In the last century this mill was occupied by a miller called Hosking. In a recently published narrative, entitled "A Drive to the Land's End," its ruins are thus described: - "In the distance stood the tower of a ruined church, venerable with age, which alone broke the monotony of the surrounding barrenness." The archæologist is recommended not to waste his time in looking for this. 



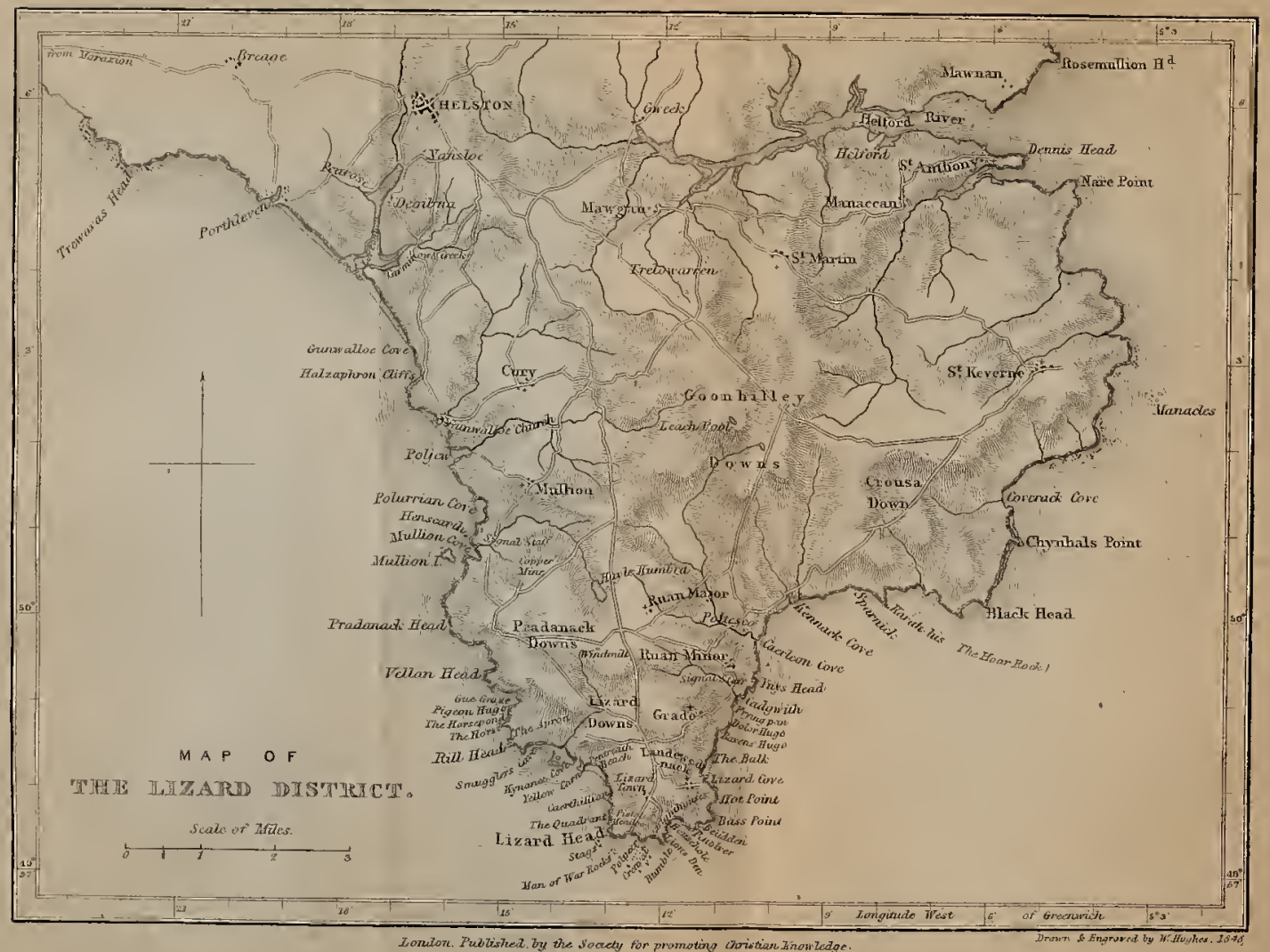




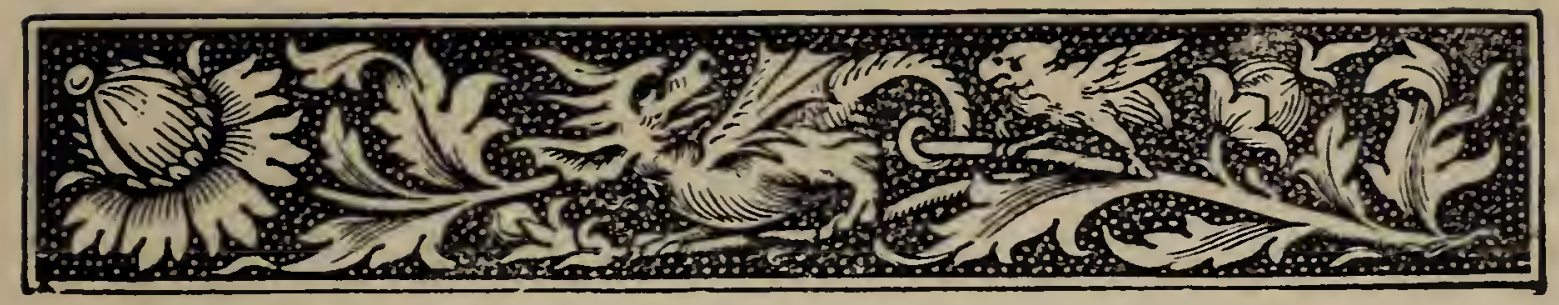

\section{A WEEK AT THE LIZARD.}

\section{CHAPTER I}

Character of the District-Fertility of Hornblende Rock-Lizard Lights-Bumble-Fishing with Fly-Lions' Den-Househole Bay-Fishing for Launces-Pen Olver-Belidden CoveBilbao Electric Cable-Beast Point-Signal Station-Hot Point-Lizard Cove - Pilchard Fishery - Landewednack Church and Cross-Peculiar Customs.

A DESERVEDLY famous writer on the picturesque, who towards the close of the last century made a tour of the West of England in pursuit of his favourite study, after making a few remarks on the first town in Cornwall which he visited, Launceston, completes his pictorial survey of the county with the following comprehensive paragraph : "From Launceston we travelled as far into Cornwall as Bodmin, through a coarse, naked country, and in all respects as uninteresting as can well be conceived. Of wood, in every shape, it was entirely destitute. Having heard that the country beyond Bodmin was exactly like what we had already passed, we resolved to travel no further in Cornwall, and instead of 
visiting the Land's End, as we had intended, we took the road to Lescard (Liskeard), proposing to visit Plymouth in our return." There is no doubt that the author of "Forest Scenery" was right in the estimate which he formed of what he saw, for the whole of the country which he traversed, like many other parts of the county, is undeniably coarse and naked, and, to a pictorial eye, most uninteresting. Long barren moors, scantily clothed with rushes, cotton-grass and stunted heath-heaps of rubbish from deserted mines, interspersed with pools of stagnant water -here and there a mine at work, but wanting, in those days, even the interest now afforded by the steam-engine-low stone walls, wearing no vegetation but gray lichens and distorted furze-bushes - such objects offer no attraction to the eye, nor occupation for the pencil of the painter; so that if Gilpin was too much pressed for time to be able to spend "A Week at the Lizard," he was quite right to alter his route.

In the present day, tourists who visit Cornwall in search of the picturesque usually travel by the railway from Plymouth to Penryn or Falmouth. The first part of the route lies through a succession of valleys, which being sheltered from the sea-breezes, are well wooded, and, owing to the dampness of the climate, abound in various kinds of ferns, \&c., of most luxuriant growth. On arriving at Truro, it would be well worth the traveller's while to explore the woods at Tregothnan, the seat of Lord Falmouth, situated on an arm of the sea, which being navigable as high up as the neat little town of Truro, expands at 
its mouth into the beautiful and commodious harbour of Falmouth; but we will suppose these and many other interesting places in the neighbourhood passed by for the present, and that the traveller has proceeded, either by the omnibus which awaits the arrival of the train or by a private carriage to Helston. This clean, and, on market days, busy little town, is situated at the root of the promontory which terminates in the Lizard, and on the west is distant from the sea a little more than two miles, being on the east three miles from an arm of the sea, which terminates at a village called Gweek. A road from Falmouth passes through Gweek to the Lizard without touching Helston, and there is a yet shorter road, by crossing the river at Helford Ferry. ${ }^{1}$ Whichever way the Lizard be approached, the road, for the last few miles at least, is very much as Gilpin describes it, "coarse and naked." A tamarisk hedge here and there, and Cornish Heath $^{2}$ everywhere, a few apple-trees shaggy with lichens and struggling to be an orchard, will be novelties which will arrest the eye of the botanist, however rapid may be his progress; while the geologist will turn aside to examine the quarries of dark, veined stone which he occasionally encounters, or, where the road is newly

I The whole district south of Helston is called Meneage, a name which those antiquarians who maintain the Oriental origin of many of the Cornish names, derive from a Persian word for "a low plant (heath) of which brooms are made." Others affirm that it means "deaf-stone," that is, non-metalliferous stone; but the Rev. Derwent Coleridge supposes that the term is identical with the Welsh " maenawg," stony.

2 Erica vagans. 
laid, he will stop to pick up specimens such as: he has never seen before except in the museums: of the curious ; but the lover of the picturesque will in all likelihood be sorely disappointed; he will have before him, for the greater part of his way, a long, weary road, skirted by commons or lined by treeless hedges, and on either side a flat, tame country, with but rarely a distant peep at the sea, and no indication of a bold coast. A companion acquainted with the country would tell him a barbarous tale connected with the tree of the district, called by way of distinction "Cury great tree," and from one point in the road would point out to him, in the remote distance, the famed St. Michael's Mount ; but these are scenes of but passing interest-there has been one long continuous ascent for many miles, and he is not aware that the ground which he is traversing is, in reality, considerably elevated above the sea, and that its termination is on every side sudden, and abruptly grand.

Tourists and visitors from the neighbouring towns generally confine their attention to two. points of interest on the coast, Kynance Cove. and the Lizard Lights, making their arrangements so as to be at the former place when the tide is lowest, and for the most part traversing the distance between by a road across a flat and singularly unattractive down. Kynance Cove undoubtedly combines more objects of interest than any other part of the coast, and the lighthouse is. an object of curiosity; as being the most southerly structure in England; so that the two will, I. dare say, continue to attract visitors who have: 
dittle time at their command, to the exclusion of many scarcely less remarkable spots; but even these visitors would do well to deviate from the usual course of going from one to the other by the road, if such it may be called, and to perform the distance (about two miles) on foot, keeping as near as possible to the edge of the cliff. The ascents and descents are neither numerous nor difficult, and the views, in whichever direction the tourist may be going, are perpetually changing, but always beautiful.

Certainly, no less time than a week should be devoted to exploring all that is worthy of being seen in the neighbourhood. The reader must, therefore, suppose himself to have taken up his quarters either at the inn, or at one of the lodging or boarding-houses in the "Lizard-town," prepared to sally forth every day on a fresh voyage of discovery.

Being so near the lighthouses - the beacon which so many of his countrymen have either bid farewell to, or greeted, with that depth of feeling which those who are doomed to be exiled for years from their native land can alone experience-he will naturally be anxious to pay them an early visit. They are visible from the village, and are within a short distance of it, being approached either by a rude carriage-road or by a path running along on the tops of the hedges or banks by which the fields are separated. Except in very stormy weather, the latter route is preferable for foot-passengers, the path being quite wide enough to allow persons to walk with safety, and, from its exposure to the sun and wind, it is 
generally dry. For the latter reason no trees grow here, and even shrubs are so rare, that one of these hedges, which has a few yards of its top fringed by stunted thorns, is called, contemptuously, Lizard Wooe. The soil consists of decomposed hornblende rock, which is so fertile, that some land which was enclosed some years since was cropped with wheat and barley for several successive years, and bore abundantly without being manured. The productiveness, no doubt, is to be attributed in a measure to the mildness of a climate, where a few days' frost constitutes a severe winter, and snow is scarcely ever seen to lie on the ground; but that it is not entirely so is evident from the fact that the serpentine formation which abounds is equally barren. The decomposed rock is called marle, and being in many places of great depth, is carted away as manure for other less-favoured districts. In some fields this process has been continued for many years, and, where this has been the case, one may walk on a hedge, which is on one side twenty or thirty feet high, on the other eight or ten. Nor is it uncommon to see one part of a field with a level many feet lower than the rest, but both bearing a fine crop of wheat or barley. When the wind is high, the walking on these double hedges is attended with some danger, for whether it blows from the south, the east, or the west, it falls with that impetuosity which is rarely found to exist except when the wind has traversed an extensive plain; and here the boundless sea is before, on the right and on the left.

The lighthouses consist of two lantern-headed 
towers connected by a long range of apartments and offices, with a continuous passage so constructed that the light-keeper who is on duty may pass from one to the other without going from under cover. The whole building is externally coated with whitewash, to insure distinctness as a landmark by day, and kept scrupulously clean both within and without. Each tower is ascended internally by a commodious staircase, and terminates in a lantern, the glass around which is so formed as to render all the rays proceeding from it horizontal. In the centre is the electric light, which superseded the old oil lamps in 1878 . The distance at which the light may be seen at night varies with the state of the atmosphere; but as the ground on which the houses stand is at a considerable elevation above the sea, it must give ample warning of danger at hand, except when the weather is unusually foggy, when a fog-horn, lately introduced, is kept constantly going. It is not unusual for birds of passage to be attracted by the brilliancy of the light, and to dash with all their force against the glass, sometimes with such impetuosity as to be stunned or even killed by the blow. Outside the lantern runs a railed gallery, from which may be obtained a splendid view of the surrounding cliffs and sea. No one is allowed to remain here or on the inside after the lighting up, a regulation which, with great propriety, is strictly enforced, for even a temporary obscuration of the light might be fraught with dangerous consequences to any vessel in the offing. 
Prior to the use of oil lamps, large fires were kept constantly burning. It is stated that during the French war, through the negligence of the light-keeper, whose turn it was to be on duty, the fire had, on one occasion, been allowed to sink so low as to be barely visible. It happened that, at the time, a packet in the employ of Government was sailing by, the captain of which roused the sleepy watchman by firing a cannonball at the dim light. No mischief was done, but the slumberer was effectually reminded of his duty.

The reader will be surprised to hear that no alteration has been made in the mode of lighting the houses for seventy years. Great alterations are, however, in contemplation; and, among other things, it has been resolved to place under the cliff, near the lighthouse, a steam-gun, to be fired every five minutes during the prevalence of a fog. This, it is hoped, will prove an effectual warning to vessels that they should keep clear of the dangerous "Stags."

Calm weather, accompanied by fog, is to be dreaded off the Lizard scarcely less than a storm; for a seaworthy ship skilfully handled, finding herself dangerously near shore, may either by day or night, if the weather be clear, in most cases beat out into a place of safety, and hold her own in deep water until the storm has abated; but during the prevalence of a sea-fog, common enough in summer in this part of the Channel, a becalmed vessel may drift quietly with the tide, and strike on a sunken rock before any one on board has caught a glimpse of land. 
A remarkable instance of this, related to me by the Rector of Landewednack, Mr. Vyvyan Robinson, occurred in I872. The "Marianna" and "Rafflino," two barks belonging to Genoa, sailed on the same day from a port in the East Indies, similarly laden with rice. They soon lost sight of each other, and did not meet again till they were about eleven days' sail from England, when the captains agreed that they would keep each other in sight till they reached Falmouth, whither they were bound for orders. On the afternoon of September I4 a very thick fog came on, and during the night they both, unknown to each other, ran on to the Stag rocks, below the lighthouse. The sea being calm the crew landed in safety. Efforts were made to get them off after the rice had been partly taken out, but without success. Rough weather came on, and they went to pieces.

Below the lighthouses, the ground suddenly slopes away and terminates in an abrupt though not lofty promontory. The turf here, as is the case in many other of the more exposed parts of the cliff, is remarkable stunted and short, though comprising several plants which, in favourable stations, attain a considerable size. In summer it is soon dried up and becomes very slippery. The points of the rock which rise above the surface in this neighbourhood are either micaslate, distinguished by being composed of scales or spangles arranged in layers, or of hornblende, a greenish-black lustrous mineral of crystalline structure, mixed with felspar. The natural appearance of the rock is, for the most part, 
concealed by a luxuriant growth of orange and yellow lichen, but in the interstices the mineral is found to be singularly unaffected by atmospheric influences, in most instances presenting as fresh an appearance on the surface as on the newly-broken rock. This point, though it seems to jut out beyond any of the others, is not in reality the extreme southerly rock, which is situated a few hundred yards to the west, and will be noticed in its proper place. The little promontory of which I am now speaking terminates abruptly in a steep cliff, the base of which is continued into the sea in the form of rugged black rocks, which, from the constant exposure to a strong tide and the lashing of the waves, are almost entirely free from sea-weeds. At their extremity rises a lofty columnar rock called the Bumble, of which the artist has given an accurate portrait in the accompanying woodcut. At low water it is accessible from the land, but on the outside is never deserted by the sea. Some years since, a gentleman who was walking round the coast attempted to climb to the top of it. When about half-way up he became terrified, and lost all power either of proceeding or retreating, and would undoubtedly have fallen, had not his perilous position been descried by a person on the cliff, who summoned to his aid from the lighthouse a young man who chanced to be working there. He, being a fearless climber, immediately ran to the spot, and by the help of ropes brought the adventurer down in safety from his perilous position, though not without 
risking his own life in the enterprise. The gentleman gratefully rewarded his deliverer by taking him into his service.

Looking to the east from the Bumble point, the tourist has before him an exceedingly beau-

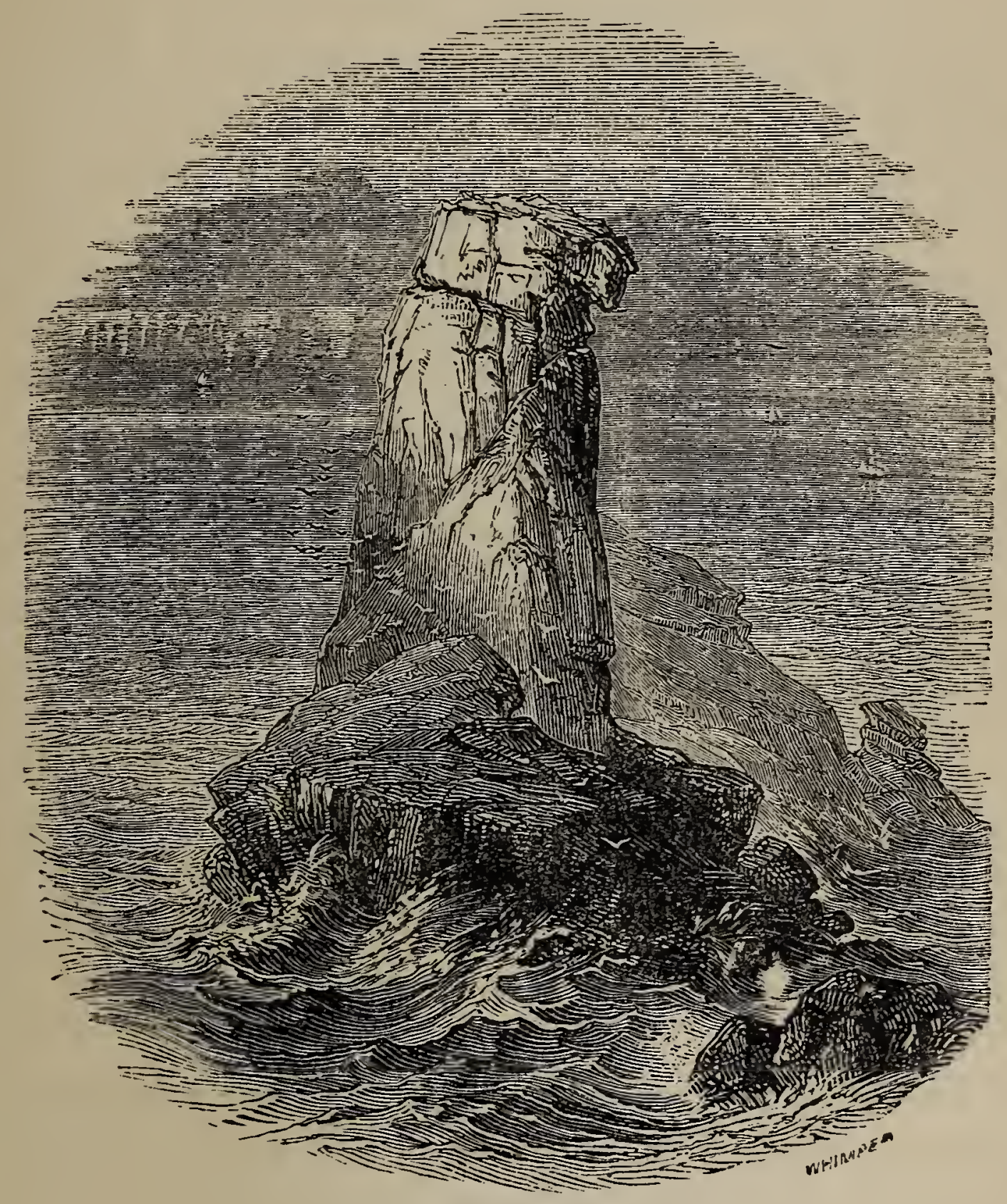

THE BUMBLE ROCK.

tiful little bay, about half a mile across, bounded on the opposite side by a rock-crowned headland called Pen Olver. At certain times of the 
tide the current sweeps round this bay; and passes the base of the Bumble with extraordinary rapidity; and here may often be seen in summer and autumn a lonely fisherman exercising that weary vocation requiring strength as well as skill. His implements consist of a long stout pole, and a few yards of strong cord attached to it. His line is furnished with a single hook, to which is attached a tuft of hair from a goat's beard, and which he is pleased to call a fly. Seen out of the water it resembles nothing in nature or art, and one might well apply the epithet "silly" to fish for allowing themselves to be caught by so rude a device. On being immersed, however, the hairs separate, and as the fisher always keeps his fly in motion by drawing it quickly along near the surface of the water, it bears a close resemblance, in shape, colour, and movement, to the little fish called a launce, which is abundant on the sandy parts of the coast. Large basse and pollack, weighing as much as twelve pounds, are unwise enough to be tempted by this mockery of a meal, and are a welcome prize to a man who fishes for a maintenance and not for sport.

Turning to the left and proceeding in a southeasterly direction, we must, after a few minutes, advance warily, for we here fall in with a singular geological phenomenon, which is well worthy of inspection, but dangerous if approached without caution. The ground east of the lighthouses slopes downwards to the edge of a cliff, about seventy or eighty feet high. Here, in 
the night of the I9th of February, I847, a portion of turf of an irregularly elliptical shape subsided, without giving any previous warning, to a depth of forty feet, forming a pit of the same depth with precipitous sides having their upper edge lined by ragged turf. It does not appear that any noise accompanied the fall of this mass, for the light-keeper was entirely unconscious of what had occurred until the next morning, when he discovered the new formation, and observed that the sea was discoloured to the distance of nearly a mile. The floor of the pit was then level, and composed of loose stones and earth, and in this state it continued for some months. Its diameter was about fifty feet in the broadest part, and the outer edge twenty feet from the brink of the cliff. It had long been known that immediately underneath this spot a cave extended from the base of the cliff in the direction of the new landslip, and it was inferred that the roof of this cave (the Daws' Hugo ${ }^{1}$, as it is called) had given way, owing perhaps to the decomposition of the rock. of which it was composed, and that the earth above had followed it. The sea entering the. cave at high water had washed away the earth and loose stones, and hence proceeded the discoloration of the water. When I first visited the spot in June, I847, the occurrence was scarcely known except in the immediate neighbourhood, and then only so far noticed that someone had cut away the overhanging turf

- Hugo is Cornish for a cave. 
to prevent accidents and had carved in large ietters on the sward:-

$$
\text { "THIS IS LIONS" DEN." }
$$

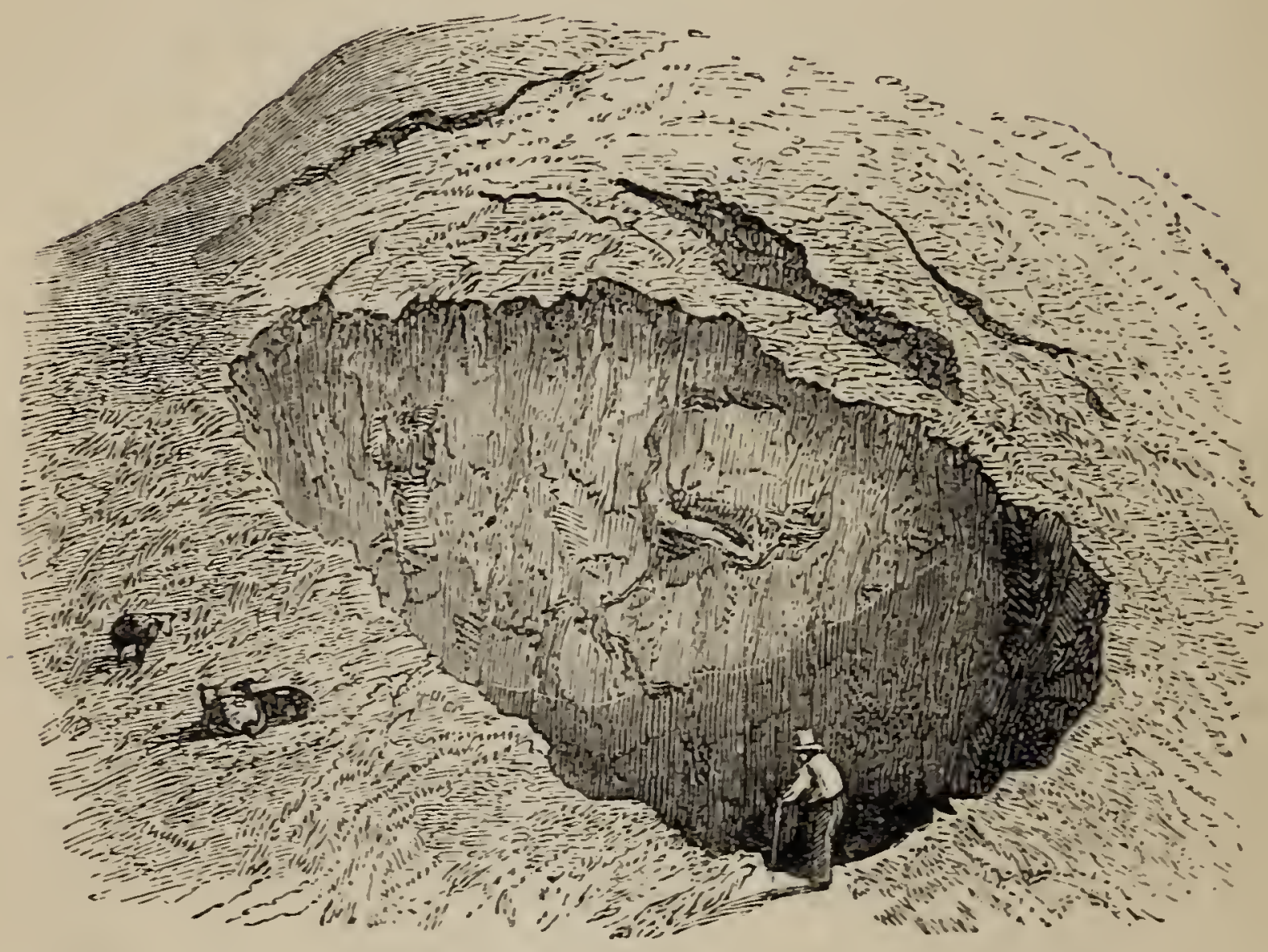

No change had taken place except that the ground on the higher side was opening in cracks, showing that it was inclined to extend landwards. After the spring tides in the beginning of July I visited it again for the purpose of ascertaining its depth, which, I found, had increased, and the floor was no longer level, but shelved towards the sea. On letting down a plummet-line, I found that the weight would not rest at a depth of sixty fect, and suspecting what had taken place, I descended the face of the cliff with the object of exploring the Daws' Hugo. The entrance to this cave, which can 
only be reached at low water, is about eight feet wide, and I should suppose about thirty feet high, divided halfway up by a horizontal layer of rocks. As I approached I saw light streaming in from the extremity of the cave, which could only proceed from the bottom of

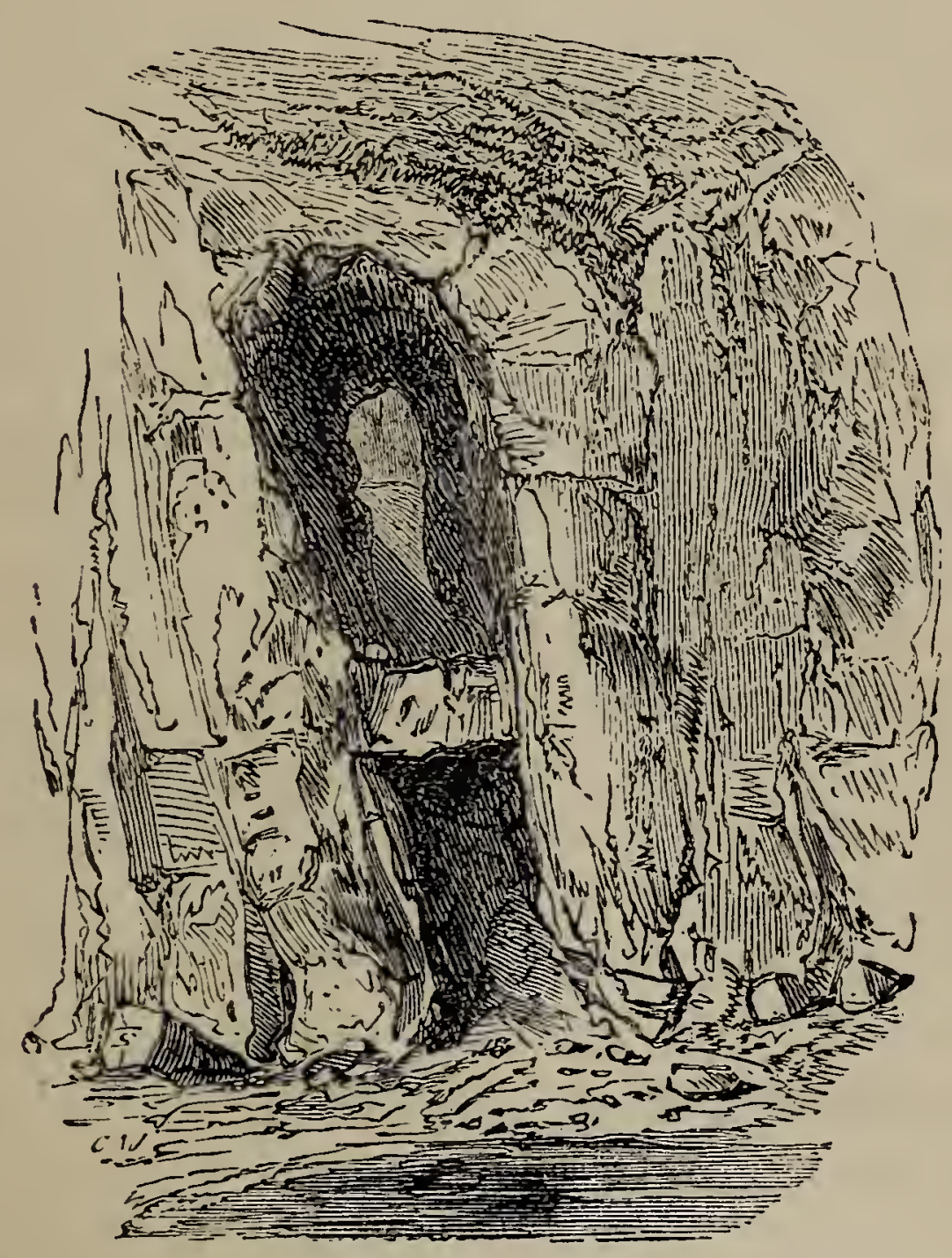

DAWs' HUGO. - Entrance to Lions' Den.

the pit; a large quantity of rubbish was still left, but it was evident that this would in time be washed away, and that eventually the sea will enter the pit through the cave at high water, where in stormy weather it will bear no fanciful resemblance to a huge boiling cauldron. If in 
course of time, as is very probable, the perpendicular walls shelve away, it will become funnelshaped, and account for the formation of another singular cavity at Cadgwith, which will be described hereafter. ${ }^{1}$

The rocks of the Lizard district are liable to be traversed by irregular veins, or lodes, as they are called, of a mineral softer than themselves; the serpentine by lodes of steatite, and the hornblende by decomposed veins of itself. When these crop out on the face of the cliff and are washed by the sea, the continued action of the water wastes away the softer particles, so that in time a cavity is formed at the base of the cliff, which increases in depth and height until either the bare surface of the hard rock is exposed, or, if the roof be of the same substance, in process of time the whole crumbles away and the sea encroaches on the land. In the case of the Daws' Hugo it would seem that a vein of soft rock extended inwards from the foot of the cliff, overarched by a layer of harder rock. Farther in, the softer stone enlarged upwards, and, not being of a compact structure, when its support was removed it fell in and formed the chasm described above, the archway of the stronger material remaining unaltered. It is not often that changes in the geological features of a district can thus be

1 The appearance at p. 14 will scarcely now (1874) be recognised. The sides of the chasm have greatly fallen in, the aperture has increased in size and has assumed a quadrilateral form, and the sea has worked its way into the bottom through Daws Hugo. The description in the text was written in 1847 . 
caught in the act of taking place; hence the Lion's Den is an object of greater interest than if it had never been observed in any other state than it is at present, and if nothing were known about its formation. A very few years, probably, will produce a great alteration in its appearance; the walls will lose their perpendicular character, at least on the land side, but how far the chasm will eventually extend must depend on the nature of the ground.

East of the Lions' Den the path winds round a much loftier cliff, ${ }^{1}$ and soon descends abruptly into a deep ravine, which runs down into a romantic little cove called Househole. The tourist may here either proceed a little inland and pass round the head of the valley, or descend by a scrambling path into the cove. The ravine itself appears to have been formed in great measure by a little stream which runs through it, having in the course of ages carried down the softer particles of soil. That it now extends farther inland than it did only a few years ago is evident from the fact that the old pathway which crossed it has lately become almost impassable, and a new one has been worn higher up. Househole Cove gives name to the little bay of which it is the extremity. It is shut in on either side by picturesque rocks, the eastern boundary of the bay, Pen Olver, being a particularly striking object. The sand

1 There is a story current in the neighbourhood that many years ago a woman either fell or threw herself from this cliff and reached the beach unhurt, her clothes having acted as a parachute. 
of which the beach consists stretches out to a considerable distance, hence the water is in fine weather of a bright green hue, which, in combination with the black rocks around, contrasts

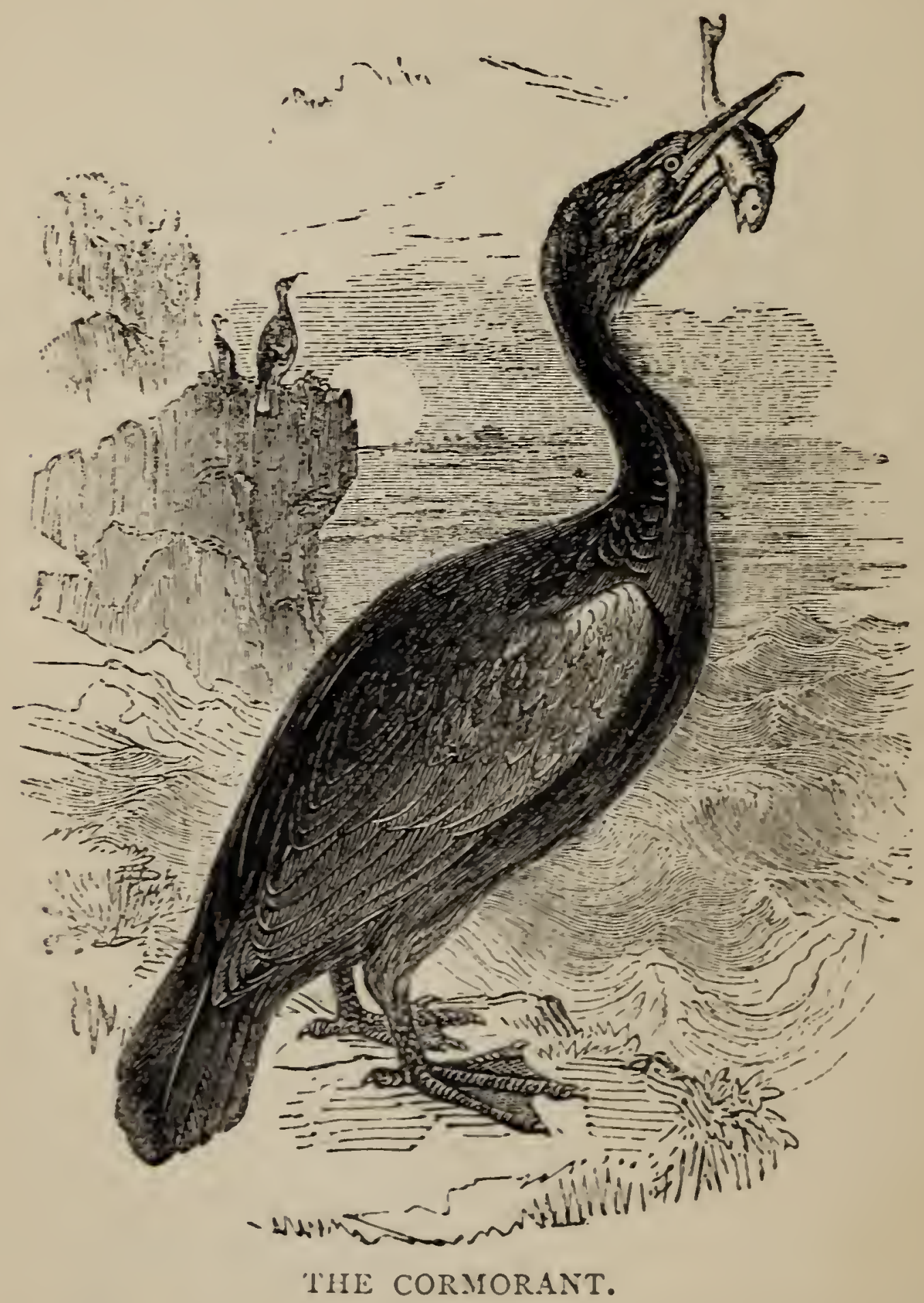

delightfully with the circling waves which roll in here with peculiar grace, and lights up the spray with a more than usually dazzling whiteness. In the sunniest weather one may always 
find a shady corner. Every vessel that passes the Lizard is visible from hence and gives animation to the distant prospect, and as most of the fish which resort to the sandy parts of the coast are here abundant, the cormorant is an unfailing visitor. One low rock in particular, near Pen Olver, generally has on it a conclave of twelve or more birds, solemnly digesting their last meal, or expanding their wings to the sun; while, in the water, a solitary head at intervals shoots up, jerks itself from side to side, and immediately disappears. It is a charming place to idle away an hour. In the moonlight summer nights the beach is often enlivened by a party of men and women fishing for launces.

The launce, or sand-eel, is a small cylindrical fish from six to twelve inches long, which by day swims about in shoals on the sandy coast, and by night burrows in the sand, keeping near the water-line. It is used by fishermen as bait for larger fish, and by others is eaten either fresh or salted. The method of catching it is quite peculiar. As it begins to grow dark the fisherman, armed with a crooked iron instrument, which with its handle is about a foot in length, buries its point a few inches in the sand which has just been left by a receding wave, and draws it towards him with a quick motion, holding his left hand ready to catch whatever he may scrape up. When he feels any impediment he lifts his hook with a jerk, bringing up a lively fish, which, if it be not immediately secured, by a few contortions of its body penetrates the sand and disappears; or, if it happen that the sand be C 2 
covered by ever so shallow a coating of water, instantly turns its head towards the sea and shoots down to meet the coming wave with such rapidity as to resemble a waving line of silver. Sometimes a Newfoundland dog accompanies the party, who with his paws fishes on his own account, never failing to seize his prize and to

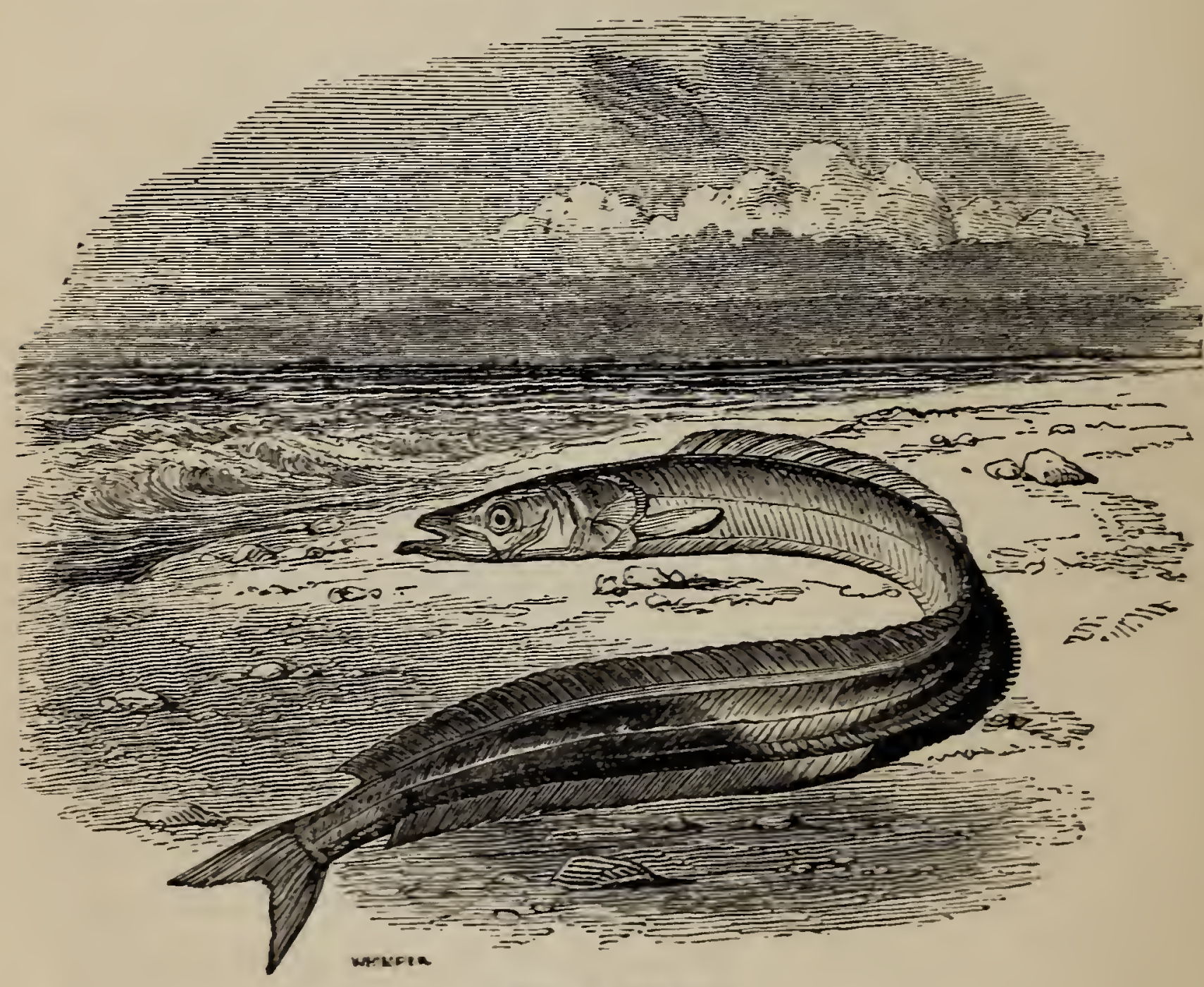

THE LAUNCE.

run off with it for security to a dry part of the beach. Moonlight nights are chosen for this occupation, as the fish are then betrayed by their silvery scales; they are also most abundant at the lowest tides, which fall at a convenient time of the night, a few days after full-moon. Much amusement is occasioned when a novice 
tries his hand, for simple though the operation is, it is much more laborious than it looks, and he either plies his hook with such force as to cut the fish in two, or suffers it to burrow again in the sand before he can secure it. A notion prevails among the fishermen that no launces will be caught if a single hook be thrust into the sand before actual low water.

Returning up the ravine and following the path on the right, we soon arrive at Pen Olver, decidedly the finest headland on the eastern side of the Lizard. Its extremity is tipped by a pile of castellated rocks, to which a covering of shaggy grey lichen imparts an air of remote antiquity, the mass of stones so closely resembling an artificial structure, that the mind naturally refers to the venerable covering as a test of the ancient date of its erection. It commands on the right a beautiful view of Househole Bay and the Lizard Lights, with the boundless ocean beyond; and on the left looks down on an almost inaccessible cove, called Belidden, which runs up to the root of the headland, and is terminated by a precipitous cliff. At Househole is landed the shore end of the Direct Spanish Electric Cable communicating with Bilbao, which passes up the cliff, under ground, to the telegraph office on the Beast Point. The neighbourhood of Bilbao is very rich in iron ore, and when matters are settled in Spain it is expected that English enterprise will be directed very largely to the opening up of these mines.

While I was walking with a companion round this part of the coast, on a very sultry day in 


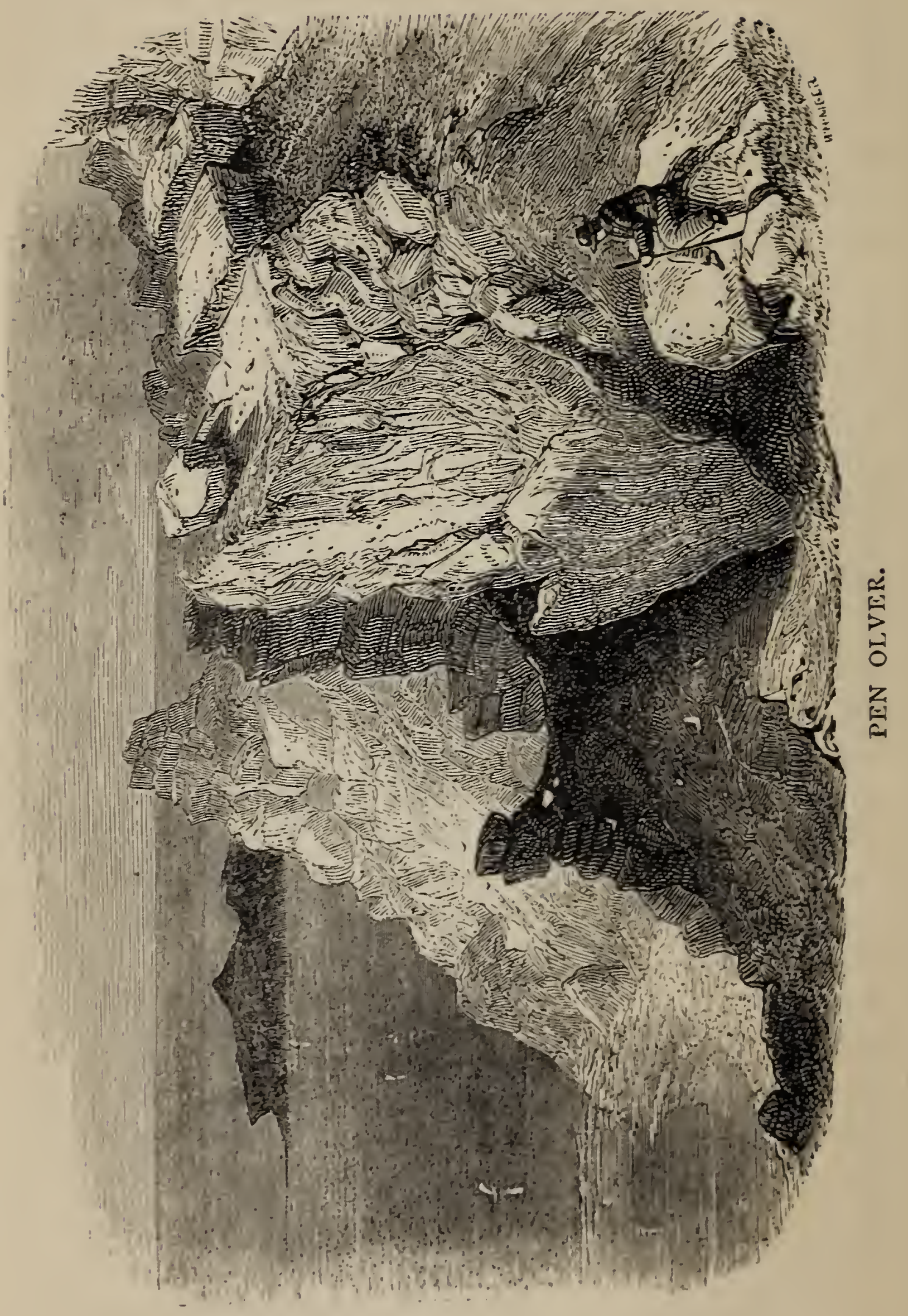


June, our attention was arrested by an intensely black cloud, many miles away, from which the rain was seen pouring literally in torrents, for no ordinary shower could have been visible at such a distance. So striking was the contrast between the deep gloom which it cast in its own neighbourhood and the dazzling brightness of the sea in the opposite direction, that my companion's sketch-book was soon put in requisition. Exposed though we were to a scorching sun, and unfanned by the lightest breath of air, we felt convinced that we should hear of some other place being visited by a terrific storm; and so it turned out, for in a few days the newspapers gave a melancholy account of a heavy flood in the eastern part of the county, so sudden and so violent in its effects, that in the course of but a few minutes the rivers had swollen above their banks, broken down bridges, rendered roads impassable, carried away cattle, haystacks, \&c., and in a few hours returned to their. wonted channels.

A short distance beyond Belidden the ground becomes rougher, being scattered with large wea.ther-beaten rocks. One group in particular, called "The Chair," is worthy of being sought out; it is composed of a flat slab, raised a little from the ground, and supporting a natural seat, with side pillars and a roof all of stone. As it is turned towards the south, it affords no shelter from the rays of the sun, but offers a convenient retreat from a shower cr boisterous wind. From this point Pen Olver has a particularly grand appearance, and the ground above is equally 


\section{A WEEK AT THE LIZARD.}

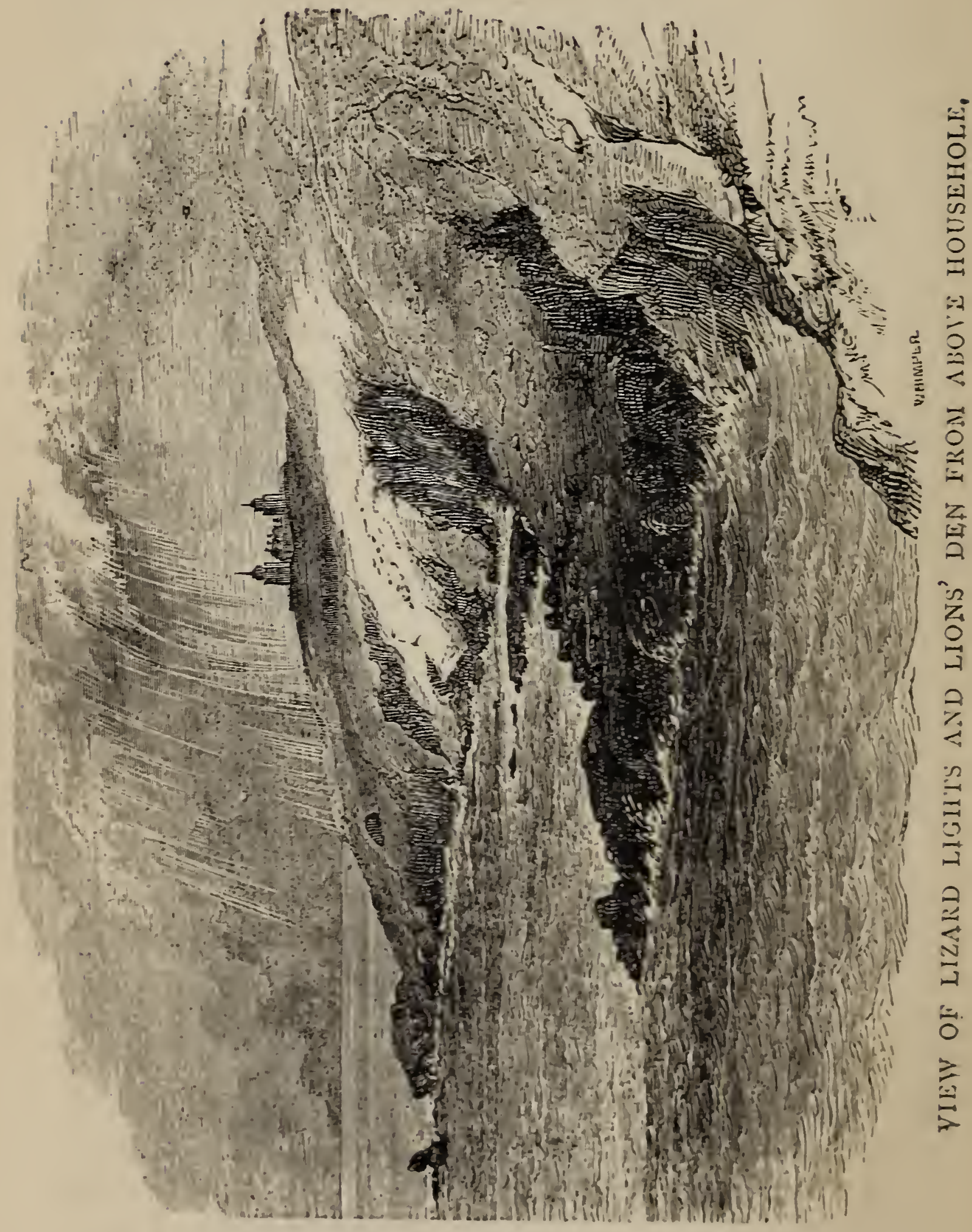


eligible for bidding farewell to Househole Bay, the Lions' Den, and the Bumble.

All along this part of the coast the rocks. assume more of the character of the trappean ${ }^{1}$ formation than is apparent elsewhere, especially if they are beheld from the sea. They do not. readily decompose from exposure to the air, nor has the sea worn away the base, consequently they present neither a slanting nor perpendicular continuous surface, but consist of huge weatherbeaten blocks and slabs, piled together in wild grandeur. The next point is usually marked in the maps "the Beast Point;" the fishermen call it "the Base," a corruption perhaps of Basse, from the fish of that name, which abounds here.

The Lizard Signal Station on Beast Point was erected and opened on April 2, 1872, by Messrs. Fox of Falmouth, who have constructed a public road to it through Tregominion Farm. Owing to their representations, the district has. been placed in telegraphic communication with the rest of the world - a want which had long. been felt. The station is situated on the highest: point of the immediate coast, and is the first land-object sighted by vessels approaching from the south. It has a flat roof, from which the signalling operations are carried on, and includes the postal telegraph office for the district.

The system of signalling is carried on by flags

Trap-rock ; a name of German origin, given to volcanic: rocks which have the tendency of rising one above another like steps. 
of different shapes and colours, by means of which commercial vessels of all nations can correspond and make their wants known by certain arbitrary signs having a universal signification. The International or Commercial Code is the one generally adopted, consisting of one

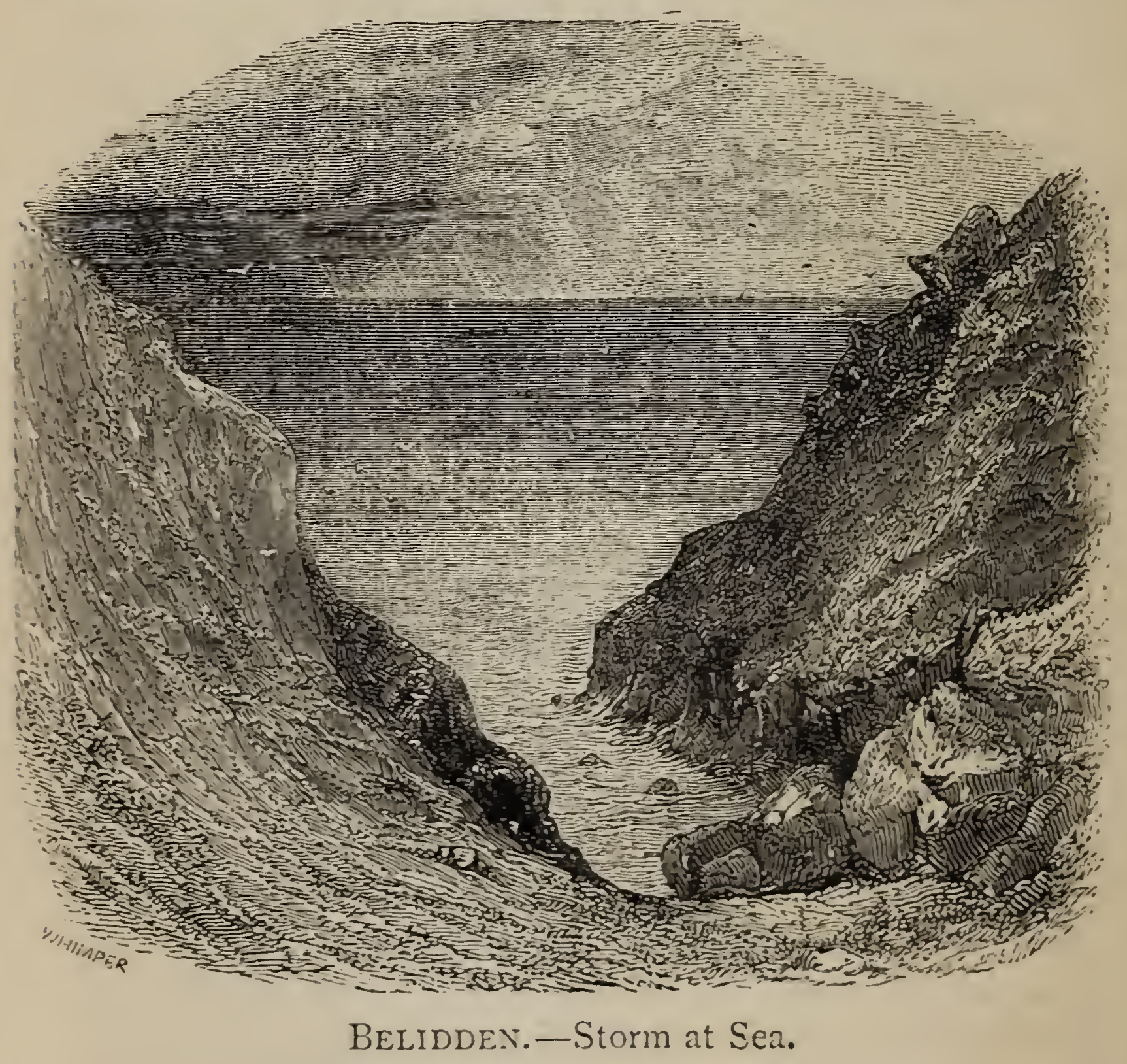

burgee (a red swallow-tailcd flag), four pennants, and thirteen rectangular flags, in addition to a code signal or answering pennant. By the transposition of these flags in hoists of two, three, or four flags, 78,642 distinct signals can be made. Every vessel has four flags or signal- 
letters allotted to it by its Government, and when these are hoisted with its national ensign, the signalmen at the station can determine each particular vessel, so that the owners of the vessel or cargo or the friends of passengers on board can be immediately communicated with by telegraph.

Each combination of flags represents a set of letters, which in their turn stand for a number; and in the International "Code-Book" are arranged numerically all the messages and replies likely to be required.

For example: a ship of any nation approaching the Lizard descries the signal ashore J D, which two letters, according to the Code-Book, stand for No. I4, and opposite I4 in the numerical arrangement of signals is the announcement, in the language of the nation to which the ship belongs, "You are running into danger." The vessel. in reply perhaps hoists flags indicating No. 4 ; and in the Code-Book No. 4 stands for "Damaged rudder. Cannot steer." Thus two signalmen may converse with each other, though neither of them understands the other's language.

By using a special preconcerted arrangement of the flags, messages not in the Code-Book may be spelt.

When the signal-flags hoisted by any vessel are discerned by the signalmen on duty, the answering pennant is " dipped " (lowered to halfmast) at the station, and the captain of the vessel understands thereby that his signal has been read; and he may then proceed to hoist fresh signals, to indicate his port of loading or 
destination, and hold any further conversation he desires.

This station is now in possession of Government.

Beyond Pen Olver is the Hot Point. By dint of a little scrambling one may here descend to the water's edge and attain a favourite fishing spot, where the tide sweeps by the feet like a rapid river. Following the safer course, the path brings us to a shed, on the brow of the cliff, used by fishermen when on the look-out for pilchards. Here an exceedingly beautiful prospect suddenly opens on the view : a noble bay about five miles across, formed by picturesque cliffs, broken into an undulating line by a succession of picturesque valleys. A flag-staff on one of the highest of these, and two or three white cottages peeping out from between the headlands, point out the locality of the fishing village and coast-guard station, Cadgwith.

Some way beyond this the land sinks; and here a narrow yellow line indicates a sandy beach, known by the name of Kennack Sands. The opposite boundary of the bay is formed by a bold, bluff headland, the Blackhead, a most appropriate name, for the whole face of the cliff, with the exception of one narrow perpendicular strip called Sparnick, is of a remarkably dingy hue. In the distance, the Deadman Point is distinctly visible, with a vessel or two entering or quitting Falmouth Harbour, which lies between; and if the weather be very clear, the Rame Head, the most easterly headland in the county, may be descried stretching out a long way on the 
horizon, as unsubstantial in appearance as a fogbank. One or two lobster-catchers are creeping along under the cliffs in their tiny vessels, and a few fishing-boats of a larger size are making for the offing, there to set their drift-nets as soon as night sets in ; just beneath us, on a projecting ledge of rock, lie the whitening bones of a lamb, killed and devoured by ravens before it was strong enough to seek safety by flight; and the deep croak of the same bird, or the shrill note of the jackdaw, divides with the dashing of the sea below us and its murmuring roll beyond the whole empire of sound.

Glorious as this scene is by day, it becomes sublime under the influence of a summer or autumn moonlight. The single broad path of glory emblazoned by a cloudless moon on the sea, at all times one of the most striking objects in nature, is here infinitely finer, and more calcu-. lated to produce a spirit of devotion, than I have ever seen it elsewhere. It is, I think, impossible for the eye to rest on that bright path, terminating as it does in a circle of mild brilliancy, without exciting the mind, the devotional mind at least, to meditate on the bright way which leads from the dark boundaries of this world to the Centre of all Light and Goodness.

After leaving the Hot Point, the path traverses a sloping piece of turf, which, being more protected from the south and west winds than the coast previously travelled over, is not so scantily furnished with vegetation; patches of fern and heath appear, and near the edge of the cliff even a honeysuckle defies the sea-breeze, and flowers 
freely. An indentation of the coast forms, a little further on, the cove of Kilkobben, which may be descended by an easy path. There are here traces of mining having been attempted at some very remote period, an excavation running in from the base of the cliff, Half-way down, two circular areas also point out where formerly

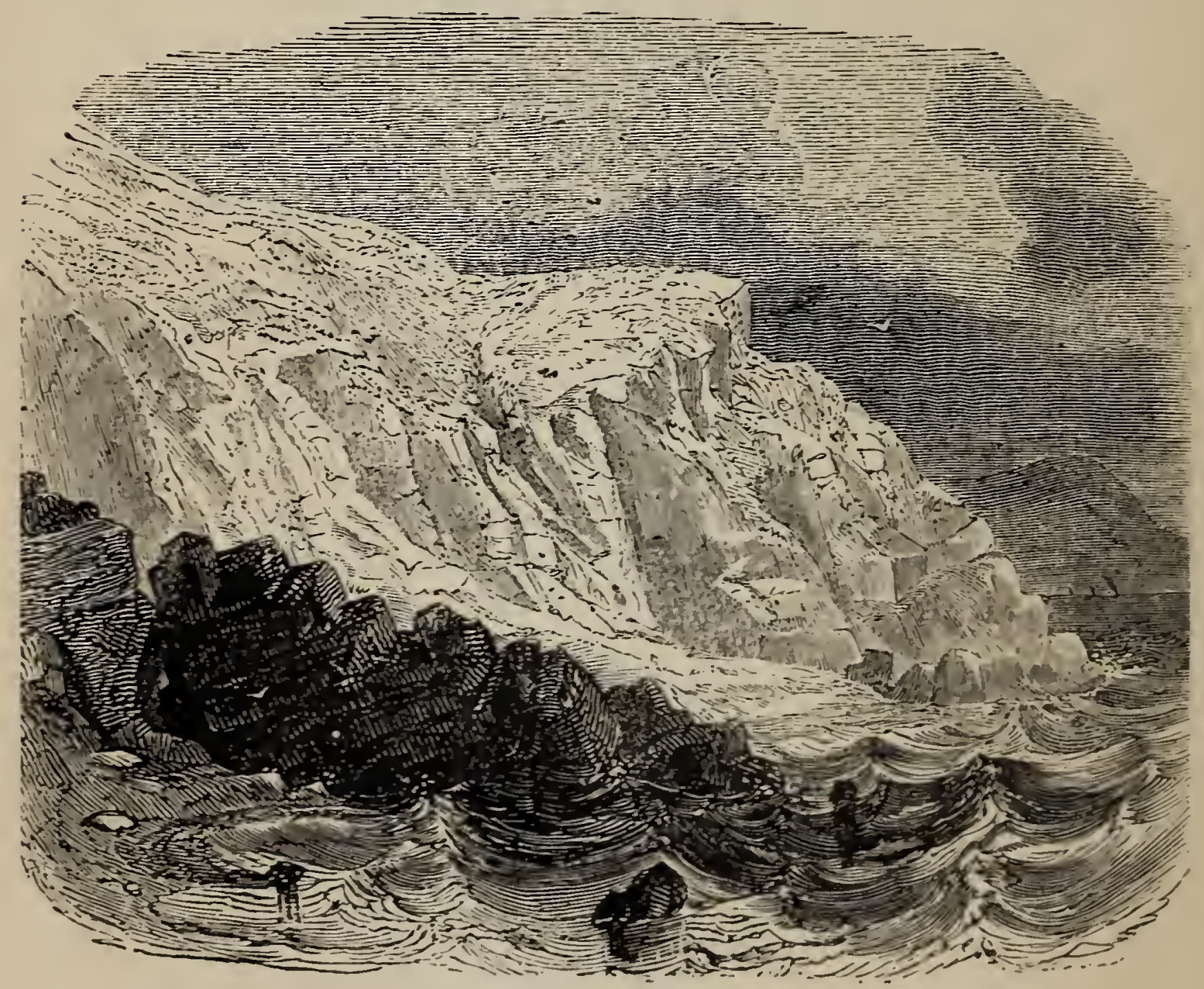

KILKOBBEN COVE.

stood two windlasses, which were employed in drawing up a seine-boat on the rock which occupies the middle of the cove. It is now entirely deserted both by miners and fishermen, the study of geology having proved the improbability of finding metallic ores in such a locality, 
and experience having shown the superiority of another cove as a fishing-station. It is now only frequented as a bathing-place, for which its pebbly beach, clearness from sea-weed, and exemption from strong currents, peculiarly adapt it.

A short distance further on, an abrupt descent brings us into Penvoose, or Lizard Cove, as it is called by way of distinction. This is the seaport of the parish; not that a large number of vessels resort hither at any time, but that a collier occasionally lands her cargo here in fine weather, running ashore when the tide is convenient, and taking care to keep out at sea if there is any prospect of a heavy landward wind. Here, too, the fishermen embark and haul up their boats when the wind is from the west or south-west. On the other side of the Lizard Point is another cove (Polpeer), which is used for the same purpose when the wind is from the east; for, generally speaking, the wind which raises a heavy sea in one of these coves has little or no effect in the other, there being a high, sheltering promontory between them. These fishermen had need to be shrewd calculators of the probability of a change of wind, or they might chance to find their boat suddenly imprisoned in a cove, from which there was no possibility of setting sail, with a calm sea on the other side, but no boat to put to sea in. Here is a fish-cellar, by which is meant, in Cornwall, a place for salting, keeping, and storing away pilchards, whenever they are caught in sufficient quantities for exportation.

It may be as well if I here say a few words 
on the subject of the pilchard fishery, that fish being not only a source of great profit to the persons engaged it its capture but supplying a staple article of food to the poor throughout the county. Pilchards are gregarious migratory fish, rather less in size than herrings, which they resemble in shape, the principal difference being that they are covered with larger scales. The greater part of the year they spend either

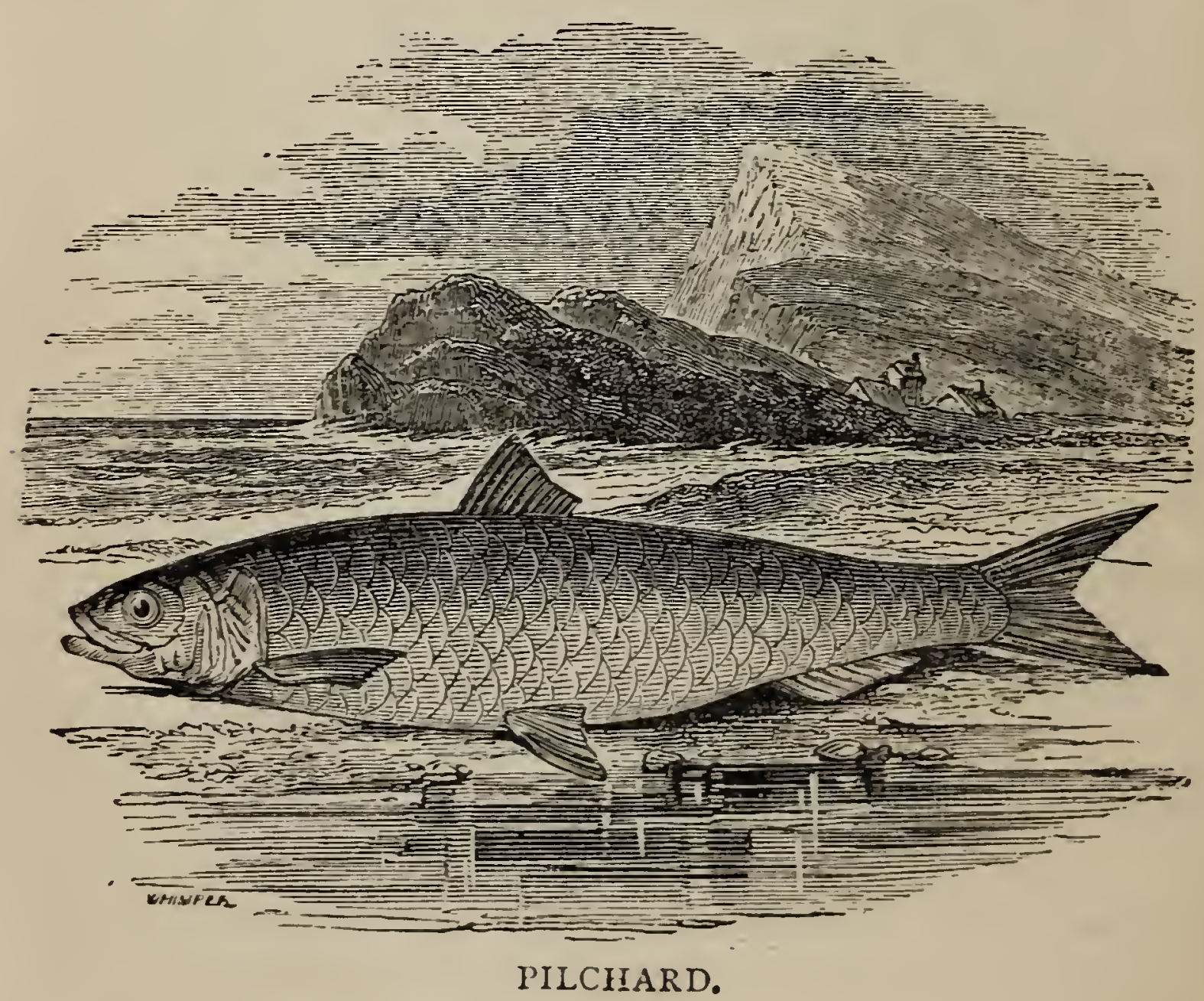

in the depths of the ocean or on the shores of some northern region; the former opinion is, I believe, the more generally received one. The fishing-season commences in the latter end of June or the beginning of July; but they are then so far from the shore that the boats employed go out to the distance of twenty miles before they 
commence operations. Each boat carries a crew of from three to six men and a boy, and a very long net about two fathoms wide, furnished at one edge with a series of corks, and at the other sinking so far as to remain vertical in the water, the corks floating on the surface.

It is a most interesting sight to watch a fleet of twenty or thirty of these boats on a fine summer afternoon issuing from behind one of the headlands of Mount's Bay, each rigged with two dark square sails, all standing on the same tack, and making for the spot which, by common consent, is considered the one where fish are most likely to abound. At nightfall the nets are set either across or parallel to the tide and suffered to drift with it, hence they are called "drift nets," and the boats "driving boats."

About midnight the nets are hauled, and the fish, which have attempted to force their way through, but have been entangled by their gills, are taken into the boats, and the nets set again. The fish, it should be observed, are not enclosed, but the nets are constructed with a mesh of such a size that the pilchard can readily insert its head, but finding the opening too small to allow a passage for its body, attempts to draw back, but is prevented by the gills, which act like the barbs of an arrow. It is only during the night, when the net is invisible or indistinctly seen, that fish are caught in this way; bright moonlight is on that account unfavourable; and when the sea abounds with phosphorescent particles, which are most conspicuous when in contact with an extraneous 
subject, or when the water is agitated, little success is expected. When the water is very foul, to use the term usually employed, the fishermen can see their nets to their full depth like a brilliant lacework of fire. In either of these latter cases the fish, as they approach the net, discover that all is not right, and turn to the right or left, not attempting to continue their course until they have passed the extremities of the obstruction. The schules (a provincial pronunciation of shoals) of pilchards are accompanied by large numbers of voracious fish, such as cod, hake, pollack, \&c., which come in for a full share of the spoil. They even attack the pilchards when suspended in the nets, so that when the latter are taken up they generally contain many half-eaten fish. Lines baited with the favourite food are thrown over by the fishermen, and generally with good success when pilchards are around the boat.

In the morning the boats return to harbour, and it is not a little interesting to watch the bustle and mercantile spirit which, for a short period, are excited in the usually quiet village. A string of a score of carts or more is drawn up at a short distance from the landing-place, each carrying three or four huge panniers, or mannds, as they are termed: the horses most contentedly munching very uninviting hay, or tugging at yet more unsavoury straw in the cart before them: the drivers in an alarming state of excitement clambering out, whip in hand, on the projecting rocks or pier, as the case may be, vociferating at the top of their very 
high voices the price per hundred they are willing to give for the fish : the wives of the fishermen with their smaller baskets more calmly waiting the arrival of their husbands' boats, climbing into them with most unfeminine agility, and returning with their two or three hundred for home-consumption, or to be sold in their neighbourhood: here and there a mother screaming to her young son to know how many hakes or congers came to his hook: fishermen, who have resolved not to take less than a certain sum, turning a deaf ear to all offers and remonstrances, abstractedly picking out from their nets the fish caught in the last haul: the fortunate purchasers, who have concluded a bargain, starting off at full speed into the interior of the country: every one talking a great deal, very loud, and with a singing intonation, which makes two-thirds of what is said unintelligible to a stranger, yet all with perfect good-humour. Such a scene is repeated every morning, until the last boat has arrived, or the last cart departed; and then the village relapses into its ordinary state of apathy, and nothing remains to bear testimony of what has been passing but a very strong smell of fish. The boats are moored and the fishermen gone home to breakfast and bed, their occupation at sea seeming to reverse the order observed by landsmen: the women are cleaning and salting their purchases: the jowsters, or hawkers, are miles away, making a good profit on their perishable commodity, and the poor making a savoury addition to their usual fare of potatoes and salt. During this season the 
fishermen have little time for rest; their boats or nets need repairs occasionally, and the latter must be spread on the cliff or an adjoining field to dry, for if heaped together in their wet state they would soon become rotten.

As the season advances the fish come nearer the shore:

When the corn is in the shock,

The fish are at the rock.

This is one of the popular rhymes which, however uncouth, always conveys a practical truth. A fleet of boats may then be seen lying-to, not more than a mile from shore, and an exceedingly pleasing appearance they present. At nightfall, as soon as the nets are set, the men light their fires and make tea, the position of the boats being pointed out by the blaze from their little stoves rising and falling with the motion of the water. If a steam-packet or other vessel is descried coming in the direction of their nets, a signal to keep off is made by kindling a wisp of straw. While the fishing is going on, the sails are taken down, and the boats are consequently unable to move out of the way; besides which, the floating corks are liable to be caught in the keels of passing vessels and carried off bodily, thus depriving the men not only of their fish but of their implements.

Now, too, another kind of fishing, and that by far the most important, is practised, which is fishing with a seine. Pilchards, I have said, always swim in shoals, and near the surface of the water. It is not unusual for a boat to be suddenly surrounded, at any time of the day, by 
myriads of fish rising to the top of the water and leaping from it, the sea itself being, as it were, in a state of effervescence. In a few minutes they are all out of sight. From the land, however, if it be elevated much above the sea, the position of the shoal is evident for a long while and to a great distance. Experienced hands can detect a shoal many miles from the shore, by the difference of colour produced in the water, as well as by unusual flights of seabirds. The excitement now becomes very great ; labourers are summoned from the harvest-fields; women finish off their household work in haste, and all are in eager anticipation of a catch on a grand scale. The seine-boats are hauled down, manned, and loaded with their nets in all haste, and proceed to the particular spot where experience has taught the fishermen they will stand the best chance of "shooting the seine" with advantage. The seine is a large net of a smaller mesh than the drift-net, but much deeper, and is furnished with corks at one edge and with leads at the other. The boat is impelled by oars, and the object of the crew is to drop the net overboard, so as to encircle a shoal of fish in shallow water. If this be done adroitly, the fish have no chance of escape, provided that the bottom be clear of rocks and no stormy weather ensue, for the leads sink one edge of the net to the bottom, the corks buoy up the other to the surface, and the ends are brought together, leaving no outlet. The difficulty is to perform this manœuvre in a place clear of rocks and not too deep for the nets, and to complete it before the rapidly-moving 
shoal has passed beyond their reach. It being impossible for a shoal at any consicierable distance to be descried from the boat, each "concern" has attached to it an experienced person, called a "hewer," who takes his stand on some high spot of ground on the nearest shore, and by preconcerted signals directs the crew towards the fish; and much of course depends on his skill and the combined intelligence, activity, and promptness of his partners. After all, the employment is one of much uncertainty; it often happens that the boats go out for many days in succession, and have no chance of trying their skill; sometimes a shoal is enclosed, but the lower part of the seine gets entangled in a rock, and being thus lifted from the bottom, every fish escapes; sometimes a shoal is surrounded, but the fish turn out to be sprats, or to be so small as to be unfit for the market; often the seine is shot, but the fish have been found to be more on the alert than the fishermen; often the fish have all disappeared before the boats have had time to put to sea; and not unfrequently a storm comes on after the fish are enclosed, which compels the fishermen to take in their nets with all speed, and return to port disappointed of their booty, but glad to have saved their boats and implements against another season. Supposing all circumstances to be favourable, the fish to be enclosed in a convenient spot, and the weather to be fine, the first thing to be done is to guess the extent of the prize, a work which requires no little experience, varying as it does from five hogsheads to $I, 500$ or 
more; opinions on this point are compared, and the prevailing one generally found to be accurate to an extraordinary degree. The seine is then moored, and, at low water, measures are adopted for taking the booty out of the water. This is effected by the help of a smaller boat, which passes within the circle of floating corks and lets down a small net, called a tuck-net, which, when filled, is drawn to the surface, and the fish are dipped up in baskets constructed for the purpose. As soon as a boat is loaded with as many as it can carry, it discharges its cargo as near as possible to the fish-cellar, and returns for another, unless the tide should in the meanwhile have risen so high as to prevent the tucking-net from being used with effect. Immediately on the arrival of the first boat, business begins on shore ; the men are employed in carrying the fish in "gurries" (hand-barrows) to the cellar, where they are deposited in heaps. And now begins a very important part of the process, the curing, which is entrusted principally to women, a large number of whom are kept at work day and night, until all are secured. The floor of the cellar is swept clean, and covered, to the distance of five or six feet from the wall, with a layer of coarse salt, on this is laid a row of fish with their tails touching the wall, outside these is laid another row with their tails touching the heads of the first, and so on, until what is considered a sufficient space is paved with fish. On this foundation-layer is placed another, each fish, however, being surrounded with salt; and this process is continued until the pile is several 
feet high, or the supply exhausted. The fish are now said to be "in bulk," in which state they are suffered to remain for some weeks, during which they are subjected to heavy pressure. The floor of the cellar slopes from the walls towards the centre, where a small channel receives the salt and water, which leaks away, and afterwards the oil which is pressed out, which last is collected and clarified. The process of salting completed, the fish are pressed into barrels, containing about 3,000 each, and are now ready for the market. Very few of these are consumed in the country, the poor having bought their own winter's stock, and salted them for themselves. The price when fresh varies from sixpence to two shillings for $\mathrm{I} 2 \mathrm{O}$ fish, according as the season is productive or otherwise. The greater part of the cellared fish are exported to the shores of the Mediterranean, where, in Roman Catholic districts at least, they are an important article of food during Lent. Naples is the principal mart; and here, if the market be overstocked, the surplus is stored away until the next year. The Italians call them fumados, ${ }^{1}$ under the impression that they have been smoked previously to being stored away; from a corruption of this word they are universally called, in Cornwall, "fair-maids," an appellation than which a less appropriate one can scarcely be conceived. The price per hogs-

1 Norden, who made his survey of Cornwall about the year ${ }_{13} 84$, says, that in his time the fish were preserved "by fuminge and drying;" and again, "The dried ware they carrye into Spayne, Italie, Venice, and divers places within the Straytes, where they are very vendible; and in those partes tooke name Fumados, for that they are dryed in the smoake:" 
head varies from thirty to fifty shillings, about a half of which latter sum is said to be clear gain to the proprietors. ${ }^{1}$

The pilchard, when fresh, is very nice broiled, either whole or split, peppered and salted. It is also very valuable to fishermen as bait for other kinds of fish. Salted, it is tough and rancid, but nevertheless highly esteemed by the poor. The usual way of dressing the cured fish is to boil them in the same saucepan with potatoes, to which they are thought to impart an agreeable flavour. The refuse fish, and the salt which has been employed in the curing, form excellent manure.

After July or August the pilchards leave the coast, and do not reappear until the end of October or beginning of November. They are then anxiously watched for in the Bristol Channel. They do not loiter about the coast, but enter St. Ives Bay on the north coast in innumerable shoals, make the circuit of the bay, and proceed towards the Land's End. They then take an easterly direction, following the windings. of the coast, and disappear until the next summer. It often happens that the sea is suddenlyobserved

1 The quantity of pilchards exported during the year 1847 , from St. Ives, Penzance, Mevagissey, Falmouth, and Newquay, was 40,883 hogsheads, being the largest quantity for the previous twenty years. There were exported to Genoa, 3,396 ; Leghorn, 7,992 ; Civita Vecchia, I, 986 ; Naples, 16,742 ; Ancona, Venice, and Trieste, I0,767. Supposing each hogshead to contain 2,500. fish, the whole number exported will amount to $102,207,500$. The average length of a fish is nine inches; and if the above. number were formed into a single line, it would extend to the distance of 145,200 miles, or form a band, six deep, round the world. Of late years the quantity annually taken has much. diminished. 


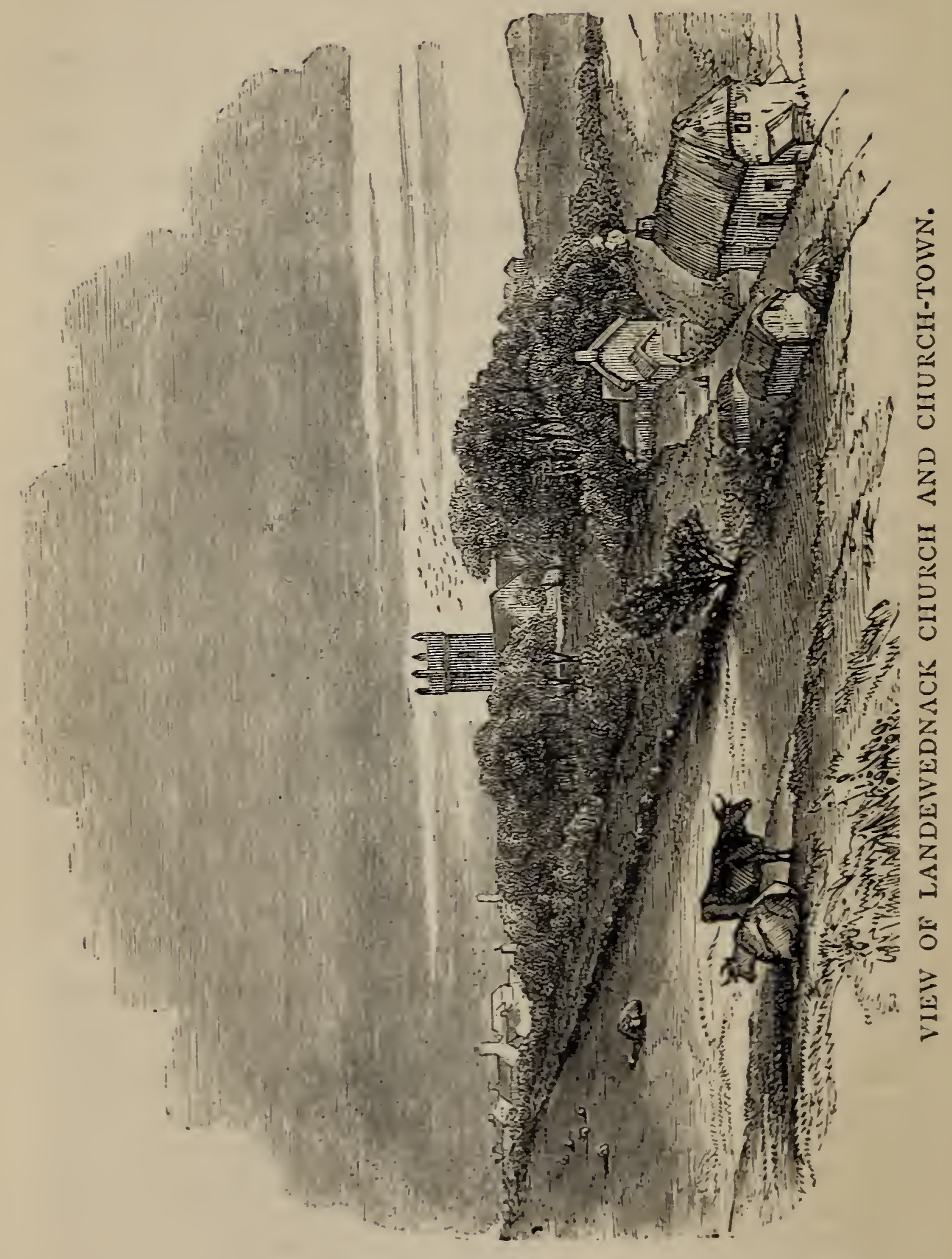


to be swarming with fish on one day, and on the next not a vestige remains. At St. Ives, where the fishery is conducted with great spirit, the progress of many of the shoals is generally arrested, and when this is the case, the air, to the distance of several miles, is impregnated with their odour for five or six weeks after. So numerous were the captures in the year I 847 , that some of the many seines which were shot on the Ist of November remained in the water until the I 5 th, owing to a deficiency of persons to take up and cure the fish, although the town was thronged by unemployed labourers of all occupations from all places within twenty miles.

From the Lizard Cove, a steep road leads up a valley about half a mile long, to the "Churchtown," such being the designation given in Cornwall to the buildings, whether many or few, which are situated in the neighbourhood of the church. The church itself, which was recently restored by the Rev. P. Vyvyan Robinson, is an unpretending but pleasing structure, surrounded by trees, which, being sheltered by rising ground in nearly all directions, here attain a greater size than anywhere else in the parish. The doorway and font are remarkable as specimens of the Norman style, and the former, from having been, until recently, coated with numerous layers of whitewash, is in a good state of preservation. A part of the churchyard, which was formerly railed off and planted, contains the graves of persons who died of the plague, and for a century has never been opened, for fear of the reappearance of that dreadful disease. A hedge adjoining the glebe has 
on its top some ancient and very large tamarisktrees, which in the flowering season are particularly beautiful. This tree is said to have been originally brought hither from St. Michael's Mount by a carter, who, having lost his whip, gathered a rod

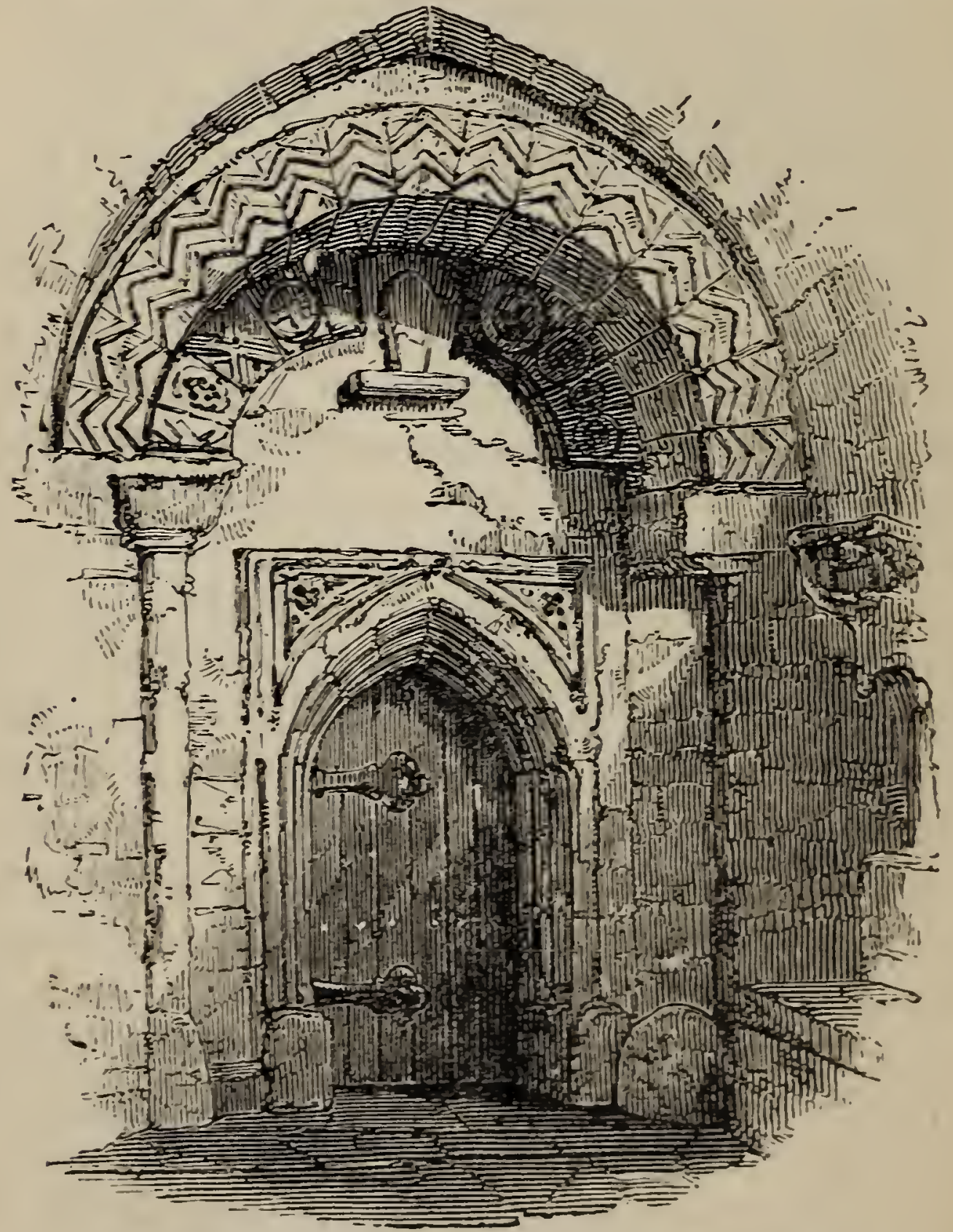

DOORWAY IN LANDEWEDNACK CHURCH.

at that place, and when arrived at the end of his journey stuck it into the ground, where it took root, and became the progenitor of all the trees of the same kind in the district. As it readily grows from cuttings planted early in spring, this 
story is not improbable. Nowhere in Cornwall is it decidedly wild, and therefore its new name of English Tamarisk $^{1}$ is inappropriate, unless there be strong evidence of its being indigenous at Hastings, where it is also abundant.

About midway between the church and Lizardtown stands a round-headed granite cross, which,

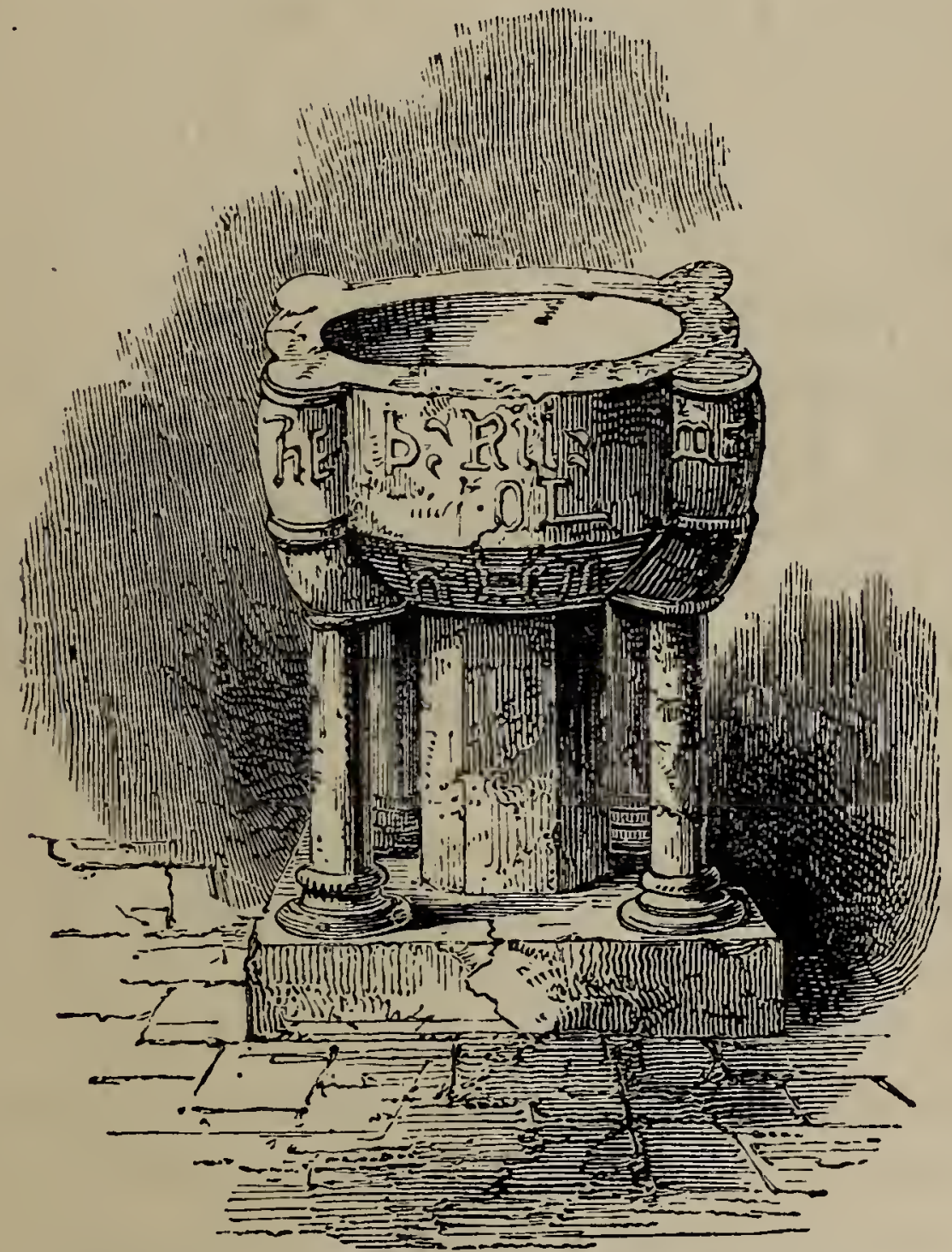

FONT IN LANDEWEDNACK CHURCH.

if we may judge from the rudeness of the sculpture, may be referred to a very ancient period. These incitements to pious thoughts in the mind of the wayfaring man are very numerous in Corn-

1 Tamarix Anglica. 
wall, but are often sadly desecrated. They may not unfrequently be seen forming the steppingstone of a stile, indifference to the purport of their erection having robbed them of all interest, whether as symbols of our faith or merely as antiquities, and a mistaken dread of being thought superstitious having prevented them from being restored to a place of security. Yet more frequently may a broken shaft be observed, applied to the same ignoble purpose. The commonest form is a flattened pillar, dilated at the top into a circular disk. The cross itself is either raised on the surface of this, or formed by sunken lines, the base being not unfrequently supported by a triangle, the emblem of the Trinity. The height varies from two to six feet.

The collection of cottages which is dignified with the name of Lizard-town contains little worthy of note. The inhabitants are in general quiet, industrious, and orderly, gaining their livelihood by fishing, or working as day-labourers in the fields. The Cornish language is now extinct as a spoken language. As might be expected, it lingered longest in the remote districts through which there was no thoroughfare, and where the inhabitants had little communication with more civilized society. "After the restoration," says Borlase, "we find the Cornish language surviving only in the more western parts, where the Rev. Mr. F. Robinson, Rector of Landewednack, is the last that I have met with who, not long before the year 1678 , preached a sermon in the Cornish language only."

Landewednack was visited by the plague in 
I645, in which year the minister, Mr. Robert Sampson, died. It is said that about a century afterwards, the part of the churchyard in which the persons were buried who had died of the pestilence was opened to receive the bodies of a number of shipwrecked mariners, upon which the plague reappeared, though in a mitigated form. In consequence of this, that part of the churchyard was fenced off and planted, and has never been reopened since.

The Rector of Ruan-minor, by ancient usage and prescription, claims a right of sending a horse into a certain field in the parish of Landewednack whenever it is cropped with corn, and taking away as many sheaves as the horse can carry on his back. A custom also existed a few years since, in this and several adjacent parishes, of paying out of the church-rates for the destruction of certain animals. Among the churchwardens' accounts, for instance, we find the following items :-

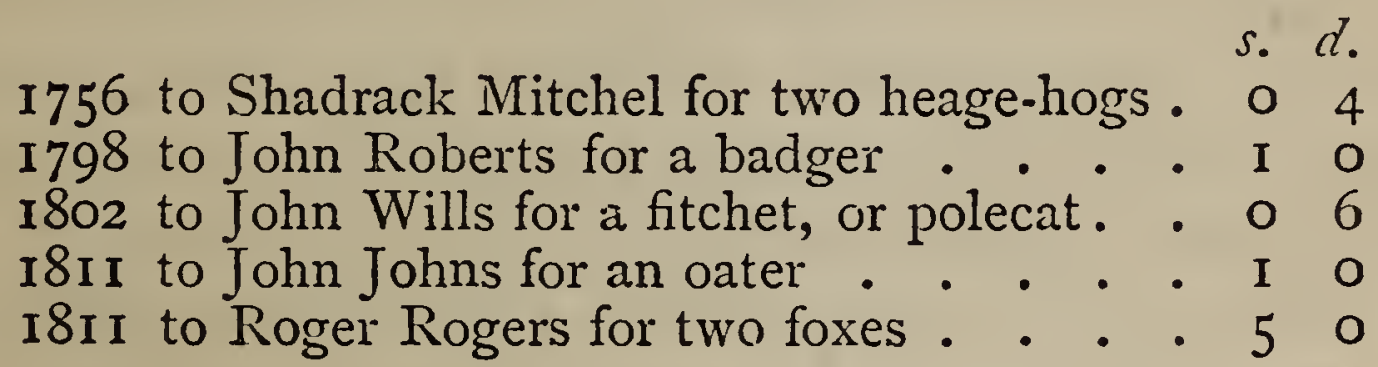

The climate of the Lizard district is salubrious, the inhabitants often attaining a great age. The Rev. Thomas Cole, minister of Landewednack, who died and was buried there in 1683 , is said in the register to have been above 120 years of age. The sexton of the same parish, Michael George, died in the same year, aged 
upwards of 100 years. Dr. Borlase speaks also of an old man upwards of 100, of the name of Collins, whom he saw on a tour to the Lizard; this man was buried in I754, aged 104 years.

A singular custom exists in the parish of Landewednack, which seems to have reference to a time when the fast of Lent was more rigidly observed than it is at present. On Shrove Tuesday, the poor children, from the ages of six to twelve, perambulate the parish begging for Colperra, probably an old Cornish word; but whatever be its meaning, they expect to receive eatables or halfpence. As few refuse to give, they collect during the day a tolerable booty in the shape of money, eggs, buns, apples, \&c. The custom has existed from time immemorial; but none of the inhabitants are acquainted with its origin. Tradition asserts that the Lizard was at some very remote period colonized by Spanish emigrants. There is still something very Spanish about the features and complexion of many of the inhabitants, and there are one or two names which indicate the same extraction. Possibly the custom alluded to above may have been introduced from the Continent.

Since writing the above, I have been told that in the parishes of Marystowe and Lamerton, in Devonshire, the children assemble in large parties on the same day, and go from door to door singing:-

"Pancake, pancake!-a penny for my labour;

I see by the string there's a good dame within,

I see by the latch I shall have a good catch;

Give me a penny, and awav I be go." 
The railway has of late years brought an increased number of visitors to the district; in consequence of which the Inn has been enlarged, respectable lodgings can be obtained, and a regular omnibus communication has been established with Helston. But the village would be made far more attractive to strangers, as well as more healthy to the inhabitants, if an improved system of drainage were established. 


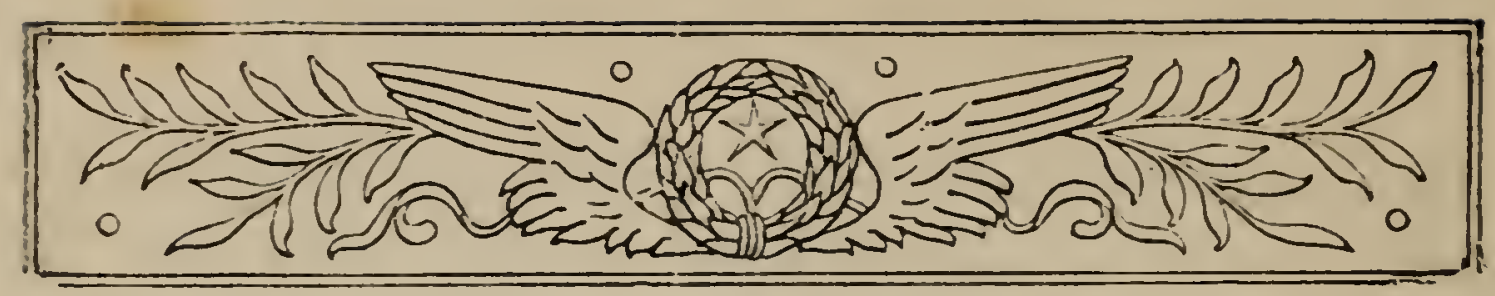

CHAPTER II.

3lost southerly point in England-Wreck on the CrenvalPolpeer Cove and Caves-Pistol Meadow-Lizard HeadCaerthillian-Kynance Cove-The Kitchen-The Bellows Asparagus Island-Caves-Variable appearance presented by the Sea.

THE uninterrupted view from the cliff in the neighbourhood of the Lizard Lights is at all times so exceedingly fine, that the tourist will scarcely object to make this his point of departure a second time, when he sets out to survey the coast towards Kynance Cove. And here he must make up his mind to a scrambling, and, if he be not tolerably active, fatiguing wali.

A narrow winding path, which follows the edge of the cliff, brings us in a few minutes to the extreme southerly rock in England, a mass of Mica slate. I am not aware of any particular mark by which it may be distinguished; one would not indeed suppose that it stretched further south than several other rocks on either side of it. But as the conductors of the Ordance Survey decided that it was the extreme 
point, the popular opinion, which was formerly in favour of other heads, is giving way. It is known in the neighbourhood by the name of the Batha. The reef of rocks which stretches out from the Lizard to a great distance, and which renders the doubling of the promontory dangerous except with a good offing, is called by the general name of the Stags, but many of the individual rocks have names of their own. A massive insulated rock, for instance, off the Batha, which is left dry every ebb-tide, is called the Island, or Crenval. It may be readily distinguished by having its summit covered with grass, and by being perforated by a natural archway. Some years since, a Quebec vessel, bound for Hull, was wrecked on the Stags in the night, and went to pieces. The crew had barely time to launch their boat, and were immediately driven on the Crenval, to the summit of which they clambered, and discovered, by the grass which grew there, that they were beyond the reach of the waves. In the morning they gained the mainland, some bringing a portion of their clothes, one man a nine-gallon cask of rum, and another a live pig, which he had brought from America as a present for his brother in England. On arriving at the village they were, to their great astonishment, greeted by their own cat, who, when the vessel went to pieces, swam ashore with the loss of her tail, which was supposed to have been pinched off between two pieces of timber. The pig was sold to a farmer in the village, and puss quartered herself at the public-house, where her E 2 
tailless condition, for many years afterwards, originated a repetition of the history of the wreck on the Crenval.

Not much further on, a tolerably good road, cut out of the solid rock, leads down to Polpeer, one of the two coves in the parish from which fishing-boats put to sea. This is a pleasant sandy recess, formed, on one side, by a reef of rocks. running out into the sea, and by a steep cliff, worn into numerous caves, on the other. One lofty-arched cavern is beautifully tapestried by marine ferns, the floor is of fine yellow sand, and all about are numerous little pools, in which the brightest coloured sea-weeds abound. Among the rocks a great variety of shells may be picked. up, though they must be hunted after with caution, for the tide comes in here very rapidly, and is liable to cut off one's retreat. I was one day wandering about on the reef at low-water, searching for shells and sea-weeds, when I suddenly observed the water rising among the loose stones, and made haste to regain the shore; and lucky it was that I discovered the turn of tide so soon, for, as it was, I had to wade through two feet of water before I reached terra firma.

But we must not leave Polpeer without noticing the fact that on no part of the English coast are home-bound vessels so liable to be wrecked as in the immediate vicinity of the Lizard. Plenty of sea-room during a protracted voyage has perhaps made the commanders of vessels careless; accidents of various kinds, such as miscalculated lee-way or set of currents, may have occasioned an error in the reckoning; but whatever may 
have been the cause, the result too frequently is that vessels steer through a mist or are driven by a tempest on the Stags or some other outlying rocks before they are conscious of being within reach of danger. Vessels of all nations are, as a rule, insufficiently provided with lifeboats, and indeed were they ever so well furnished, the best boats would be comparatively useless in such an emergency, on account of the inhospitable character of the coast. The coves into which boats can be steered are very few, and so difficult of access, as to be actually nonexistent except for persons intimately acquainted with their position and surroundings. It is therefore absolutely necessary that every boat landing in the neighbourhood of the Lizard should have on board, besides a good crew of rowers, some one competent to direct her course. Hence the necessity for life-boats-large, artistically constructed boats-manned by strong and skilled hands, prepared to sacrifice their own lives in the effort to save the lives of others, who, though strangers and perhaps foreigners, are still their fellow-creatures, and, as such, fit objects for selfdevotion. No mere mercenary motive can possibly afford an inducement to the brave fellows who volunteer into a life-boat to run the risks which they cheerfully incur; for the remuneration awarded them is, sad to say, paltry. There are reasons for everything, and I daresay there may be good ones why the whole system of lifeboats is not in the hands of Government at the national expense. But such is not the case. The Polpeer life-boat is supported by voluntary 
contributions; and visitors are earnestly recommended, after having visited and examined the contents of the boat-house, to discover the Donation-box, and to deposit in it any sum not

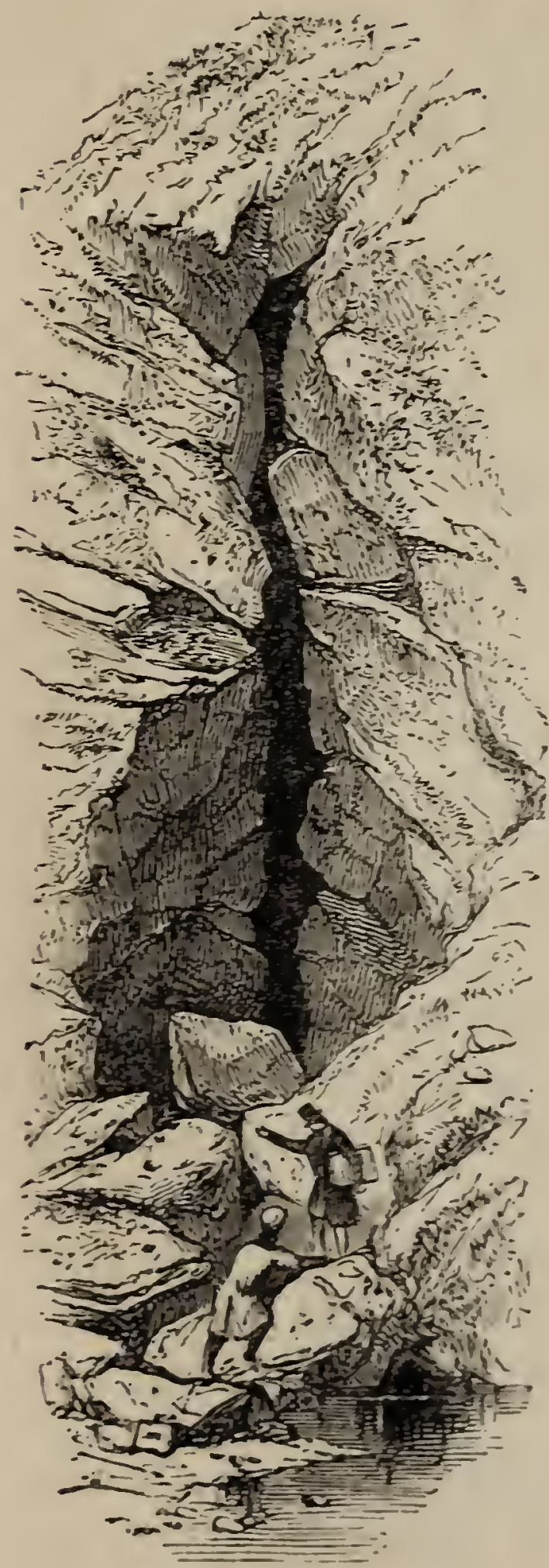

CAVE AT POLPEER. exceeding a sovereign. Larger donations and the names of annual subscribers may safely be left with the Rector, himself a volunteer. The Polpeer boat was established in I860, and has saved seventeen lives, and assisted in rescuing from destruction two valuable vessels. There are other life-boats at Cadgwith, Mullion, Porthoustock, and Porthleven.

We can with some little difficulty proceed about a hundred yards close to the base of a cliff, until we reach a ledge of rock which is impassable. At this point, facing round to the land, we observe a ragged perpendicular chink in the cliff, the lower part of which is blocked up by a huge mass of rock. ${ }^{1}$ If we

' For the convenience of the numerous tourists who now visit this cave, the guides have recently made the entrance easier. 
either crawl under or climb over this, we find ourselves in a deep and lofty cavern extending a considerable distance inwards, and lighted from the south by the aperture alreadydescribed, and, a little further in, by a similar cleft that looks towards the west. An exit is easily effected through the latter passage, but at the expense of a wet foot, for a pool of water occupies the entrance, and the rocks are too steep to admit of being as cended. This cave, though littleknown, is one of the most striking on the coast, being remarkable not only for the bold outline of its orifices, but from presenting two entirely different views, owing to its being situated exactly at the point where the line of

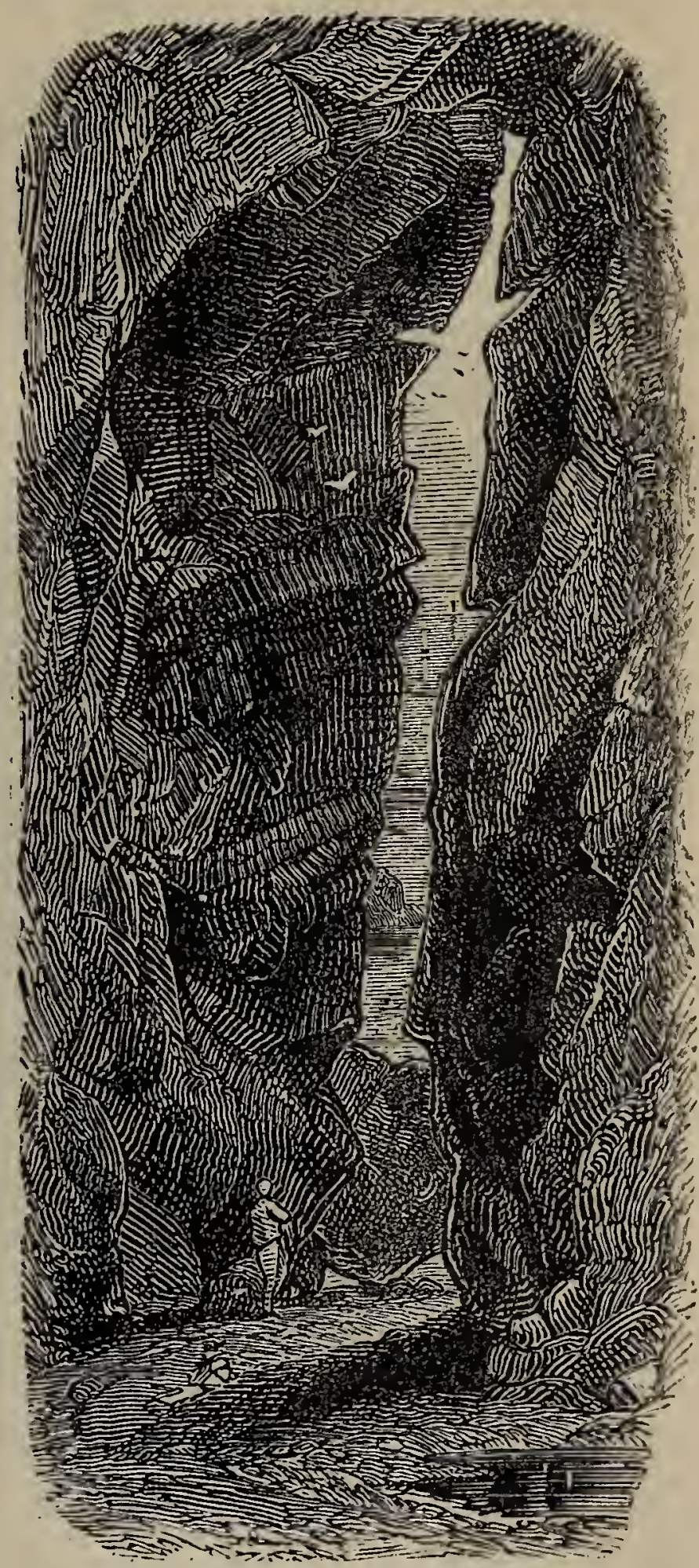

CAVE AT POLPEER.

coast takes a new direction. The walls of the cave are thickly covered with a dense conferva-like vegetable, and appear as if lined with ricln 
purple velvet. For some distance beyond this, the rocks are curiously eaten out or perforated, but care must be taken that they be visited before low water, for to be caught there by the

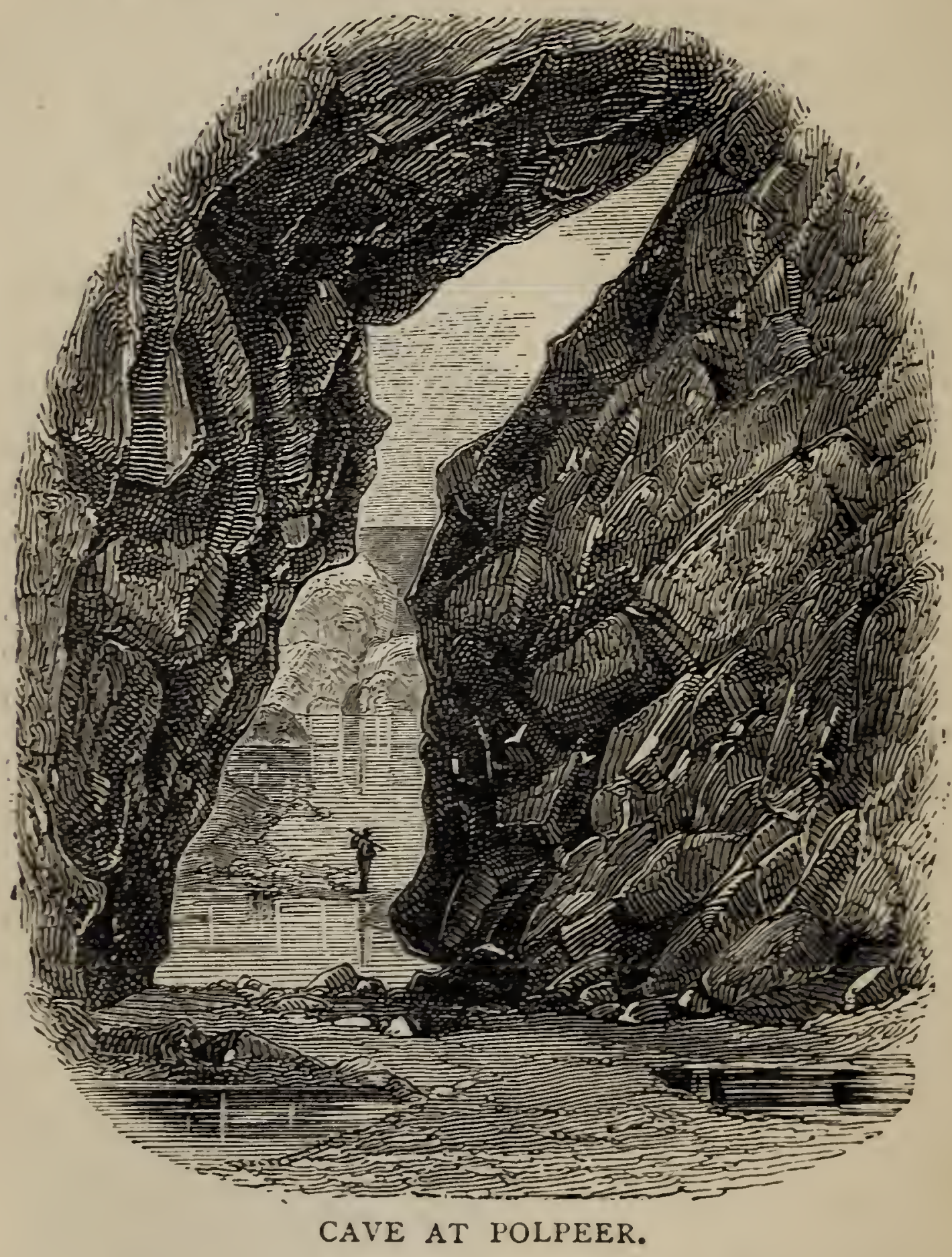

rising tide would be perilous in the extreme. After a scramble of about half a mile in length, we reach another slight turn in the coast, where deep water meets the base of the cliff, and as there is here no friendly double-mouthed cave to 
help us over the difficulty, our only alternative is to ascend to the summit of the cliff.

Pursuing our way in the same direction, we descend into a meadow, several mounds in which indicate that it is the burying-place of more than one shipwrecked mariner. Of all the tales of shipwreck told at the Lizard, the story connected with Pistol Meadow ${ }^{1}$ is the saddest and most frequently repeated. Its date I could not ascertain, but it must, I concluded, have taken place more than a century ago. A transport, having on board the governor of some distant colony, with his suite and 700 men, was driven on a group of rocks, still called from the incident the Man-of-war Rocks, and dashed to pieces. Two only of the whole company reached the shore alive, and these two, it is said, being well acquainted with the coast, had ventured to remonstrate with the captain for steering his course so near the dangerous headland. They were rewarded by being put in irons, and in irons they were washed ashore, to bear testimony to their captain's obstinacy. Two hundred dead bodies were subsequently washed on shore, and buried in pits, containing from twenty to thirty each, in this meadow. Thirty years ago the fishermen said that they could even then descry, with the help of their water-glasses, pieces of cannon lying at the bottom where the ship went to pieces; and they also averred that dogs of all kinds were held in great detestation in the

1 The word "Pistol" is supposed to be a corruption of the ancient British Pistyll, a spout or cataract from the stream which flows through the meadow and falls down the cliff. 
parish, because a great number of these animals. assembled from all parts of the country to devour the dead bodies which were then washed ashore. ${ }^{1}$ Many persons in the parish are still afraid to pass through Pistol Meadow after dark.

Seen from the sea, a little to the eastward, the Lizard Head presents a striking resemblance to the mutilated head and face of a sphinx. The land view, as seen by a spectator standing on the path to Kynance, presents a massive bust of the late Lord Brougham.

From the bold headland beyond this gloomy spot a new scene suddenly opens on the tourist, and by far the grandest and most picturesque that he has yet met with. The promontory on which he stands terminates in three masses of lofty piled rocks, of which the most easterly is called the Little Lizard, the westerly and the largest the Old Lizard Head. A short way off

1 Many years ago I heard, in a fishing village a few miles east of the Lizard, an anecdote which would seem to show that the fishermen of this coast formerly entertained a superstitious dislike of all quadrupeds. It was then considered highly improper to mention the name of any four-footed beast after the boat had put out to sea; so far did this feeling extend, that if any one of the crew, either accidentally or intentionally, mentioned the name of one, it was considered the greatest foolhardiness to persevere in the expedition. It had happened that a quarrel had taken place between two fishermen belonging to different boats, and the one who considered himself aggrieved adopted the following strange method of revenge. After dark he boarded his enemy's boat, secretly nailed to the bow the foot of a fox, and went home. Next morning, when the boats were on the point of starting for their respective destinations, the trick was dis. covered, when the party on whom the trick had been played immediately lowered their sails, returned to shore, and did not venture out again for the remainder of the day. 
from the shore is a black rock called the Quad. rant. The headland which forms the opposite extremity of the little bay to the west is called the Rill: Kynance Cove is strongly marked by its group of towering rocks about the middle of the sweep; and in front of Kynance an isolated mass of lofty rock called Innis Vean, or, the Lion-rock, appears to have been cut off from the mainland by some instantaneous convulsion of nature. Higher than any of these towers is a pile of craggy rocks looking down on Kynance, called the Tar Box, a corruption, it has been suggested, of Tor Balk.

An easy walk of about twenty minutes brings us to Caerthillian, a ravine through which runs a stream of water. Stepping over this, we ascend by a series of steps cut in the steep turf to a pile of rocks, not remarkable for height or grandeur, but commanding a beautiful view on one side of Kynance and the Rill, and on the other, of the ground which we have just traversed. If the sky be clear, and the hour of sunset not far distant, it will be well worth while to sit here and watch the sun going down behind the Rill. As we look toward the west, the rugged projections of the cliffs melt away into an uniform purple as rich as the boldest landscape-painter will dare to transfer to his canvas, while the headland to the left has its very least inequalities of surface brought prominently forward with broad red light, or thrown back into positive shadow with a distinctness not to be observed at any other period of the day.

If the tourist be here overtaken by sunset, he 
had better defer his first visit to Kynance until the morrow; for he has yet a good way to go, and too many objects of interest remain, that he should content himself with a mere hasty twilight inspection of them. In this case, he may either retrace his steps and be ready to watch the rising of the moon from the Lizard Point, or proceed direct by a pathway across the fields to the village. But if he have plenty of time before him, he may press on, and will speedily reach Holestrow. This remarkable spot apparently owes its formation to the sudden falling away of an immense mass of the cliff, the perpendicular side of which is turned towards the sea, but separated from it by a depressed platform of turf and loose stones, which latter have fallen from the rocks above. The base of the false cliff, if it may be so termed, is concealed by masses of rock, which, from their fresh colour, appear to have recently fallen, and the whole place resembles a huge quarry. Here may be found some of the most curious varieties of veined sepentine, broken into pieces of a convenient size for the collector to carry away. They are often worked into candlesticks, inkstands, letterpresses, \&c., and take a good polish, but are for the most part so liable to fracture, that they are rarely formed into larger articles.

Just beyond this, great care must be taken in approaching the edge, for owing to a peculiar rise of the ground, the tourist may, in a certain spot, be standing within a few feet of the brink of a terrific precipice without being at all aware of it. This is the Yellow Cairn, an abrupt promontory 
200 feet high, and so perpendicular, that a plummet might be dropped from the summit into the sea, or at least among the rocks beneath. It is separated from an immense insulated rock called Innis Vean by a channel, which is constantly being widened by the falling away of new portions of the mainland. A gentleman informed me that he was standing on a rock hard by, a few years since, when a mass of loose stone forming a large portion of the face of this cliff fell with terrific noise into the sea. Innis Vean, from its inaccessible nature, is a favourite resort of sea-birds.

We have now to descend for a short distance, cross the bed of a stream, the course of which is marked by great stones and aquatic plants, and, after mounting the acclivity on the opposite side, soon arrive at the Tor Balk, from the top of which the view represented in the frontispiece suddenly bursts on the sight, a view much easier to be remembered than described.

The celebrated antiquarian, Charles Littleton, Dean of Exeter, subsequently Bishop of Carlisle, made a tour through Cornwall with the historian of Cornwall, Dr. Borlase, and thus describes his impression of the Lizard, and, more particularly, Kynance Cove :-

"The next morning Mr. Borlase and myself set out after Breakfast for the Lizard Point. Our Way lay through the Goonhelly Downs, which are no other than boggy, naked, barren moors, with not a Tree or even a Shrub to be seen for 8 or 9 miles riding. At the end of these Downs, you come to a miserable Village, and a mile further another rotten moor brings you to a Glyn or 
narrow Valley, the sides of which are sow'd as it were with vast masses of Rag-Stone. At the top of this Glyn we left our horses, and descended into the Valley on foot. When we arrived at the extremity of it, a natural Arched Entrance through a vast Red Rock led us into the finest piece of Scenery that sportive Nature ever produced: on the right hand you see the boldest Rocky shore glistening with spars and mundicks, and enamelled with a thousand different hues. Under these Rocks the Sea has formed Cavities large enough to admit of twenty People commodiously in each Cove; from one you see a little arm of the Sea, which at Low Water comes within less than twenty Yards of you, dashing its waves against a vast Rock that stands entirely detach'd from any other. From another Cove you have a sight of the Ocean, but agreeably interrupted on the right hand by an immense high broken Rock, detached, like the former, from the Rocks which join the main Land; and this Rock, as well as all the others, is alike enamell'd with the most beautiful Colours, and decorated with Samphire and other Sea Plants which hang down from several parts of it. It is impossible, without your Poetical Genius, to do justice to this singular scene, for there are a Thousand Beautys still to be described, which a dull narration will give you no Idea of. The excessive shining whiteness of the Sand, and several small Basons full of Limpid Sea Water, which the tide leaves behind when the Sea is out, the various Windings and Turnings which the different Groups of Rocks oblige you to make in traversing this splendid Court of 
Neptune, ought all to be taken into the Description, but the task is too great for me, and therefore I must refer you to Mr. Borlase's Drawing for the general Idea of the Place, and for the singular beauty of the stones which these rocks consist of, to a small specimen, which I shall bring with me to HAGLEY.

"N.B. The name of the place is Kinance, very near the famous Soapy Rock at the Lizard Point, which you know is the most Southerly Point in Great Britain. Miller will find it in the Map near Landewenock Parish. On my return from hence to Trelowarren, I call'd at the Lizard Village upon an old man, who was reported to be I I I years of age, but on talking with him, I think he is not so old by six years; however, he is old enough to remember very well a dispute between a Blacksmith and Tanner in his own Parish, the one a Royalist the other a Parliamentarian, concerning Charles 2nd right to the crown, just before the Restoration, which did not end till they had thrashed each other stoutly, but the honest Cavalier had the better of his Antagonist, who was at last willing (as the old man told me) to let the King come quietly home and enjoy his own. This ancient Cornu-Britain has all his senses perfect, except his Hearing, which he has not quite lost, never was blooded in his Life, and seldom took Physick, nor ever had the Small Pox."

It is necessary, however, that we should describe the most interesting features of this romantic spot more in detail ; and in order that we may do this, we must request the reader once more to turn to 
the frontispiece. Descending the deep ravine between the spectator and the scene before us, by a rough winding road on the right, we pass by the mill, and a cottage where refreshments and polished specimens of serpentine are sold, and step at once on the firm white sand with which, during the summer months, the cove is filled.

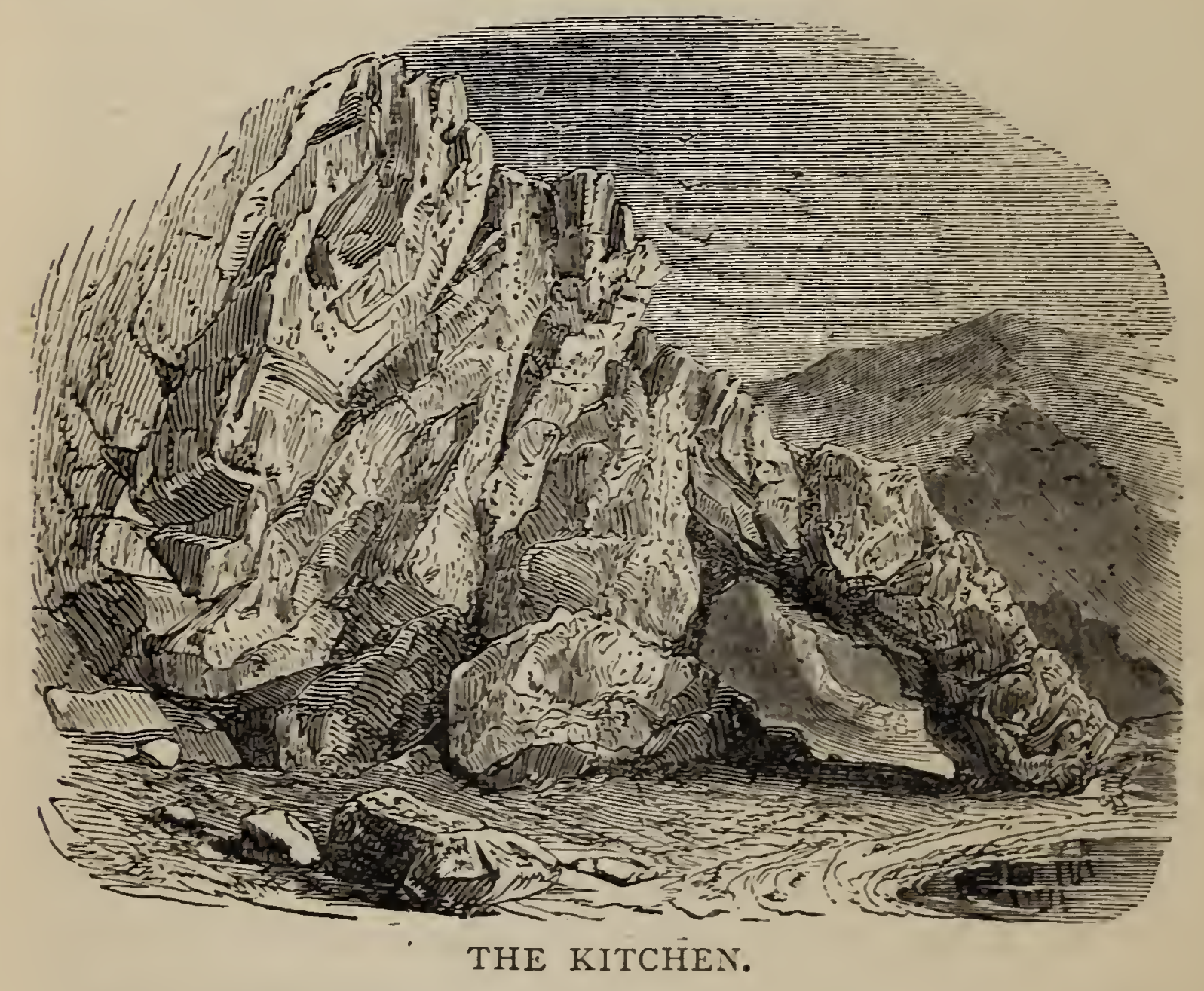

Turning to the right, we may pass through either of the natural archways represented in the frontispiece, ${ }^{1}$ and, if the tide be in, must here wait, in a recess called the Kitchen, until the water has receded from the point which it now just washes. Having passed this, we come out

1 These archways have, since the sketch was taken, been washed away by the sea. 
on a platform of sand raised above the level of the rest of the beach by the washing of the sea round the isolated rocks which occupy the middle of the cove. The central island, in the shape of a depressed cone, is covered with herbage, and is called from the plant,' which grows on it in considerable quantities, Asparagus Island. It may readily be ascended on the western or right side;

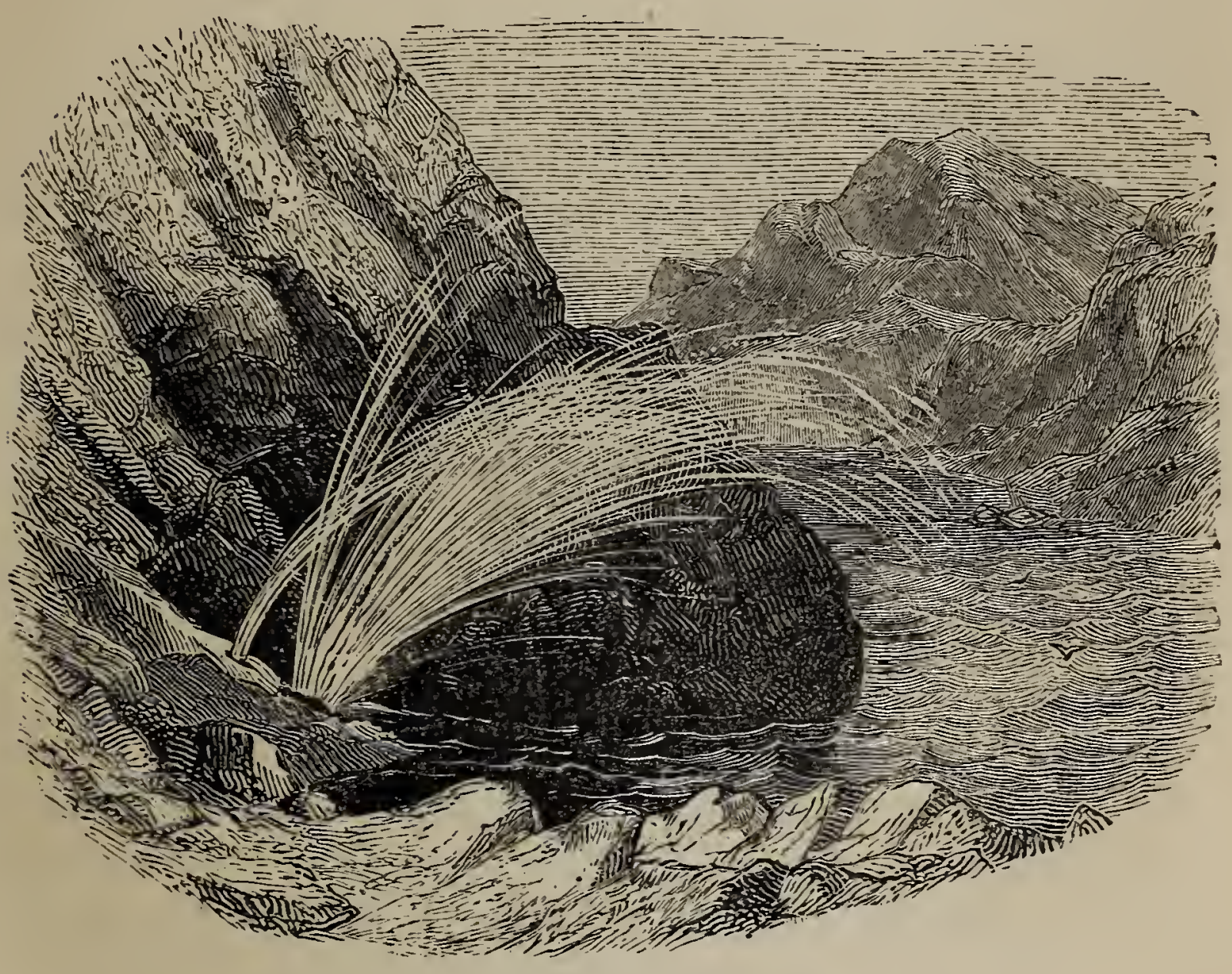

THE BELLOWS.

but before we have proceeded far, the attention is arrested by a loud roaring noise which issues from two holes in the rock, followed by a jet of water, which, if the sea be stormy, is driven out with such force as to envelope us in a cloud of mist. The lower of these holes is not inaptly called the

1 Asparagus officinalis. 
Bellows; the upper is known by the name of the Post Office, because, if a sheet of paper be held near the orifice, it is violently torn from the hand by the inward current of air, and carried in with a loud noise. Asparagus Island is evidently traversed by a subterranean tunnel, formed probably by the decomposition of a lode of soft rock. One extremity is on the sea-side of the island, and, as the tide rises, is periodically filled with water, which, rushing in through the opening every time that a wave beats against it, forcibly expels air and water through the Bellows and Post Office. As the wave recedes through the seaward orifice, the air rushes in through the openings on the land side, and this process is repeated as long as both extremities are exposed to the rising and falling of the waves, being more or less violent according as the sea is rough or smooth. At lowwater, when the waves do not rise to the external opening, and at high water, when the tunnel is filled, no effect is produced. Great caution must be used in approaching the Bellows, for the water often rises instantaneously after some minutes of perfect rest, and would sweep one away with irresistible force. I was once standing here, waiting to see the Bellows work, when a gentleman of the party imprudently ventured to peep into the Post Office. He had scarcely brought his eye to the orifice, when, without the least warning, out burst a jet of water which knocked off his hat into the sea, drenched the upper part of his person, and terrified him and his companions not a little, though he escaped with the loss of his hat.

The remainder of the ascent is not difficult. 
Once arrived at the summit, a stretch on the long soft grass, and a quiet gaze on the enchanting scenery all around, make ample amends for whatever fatigue may have been incurred.

Asparagus Island is separated from the pinnacled rock beyond it by a deep narrow channel, which is at all times filled with water. Some adventurous climbers spring across this and ascend to the very top of the Gull Rock; but the risk is great, and there can be but little to reward them for their pains beyond a bird's-eye view of the cove, scarcely more commanding than that from the island.

Descending by the eastern side of the island, by a difficult and somewhat dangerous path, if path it can be called, we encounter a huge cavernous hole, at the bottom of which the sea boils with terrific fury. Once arrived at the mouth, there is no difficulty in descending into it far enough to see the light shining through from the opposite side of the island, and to discover the channel by which the waves gained admission into the roaring caldron. The contrast here exhibited between the snow-white foam and the black polished rocks is very fine, but unless the tourist has good nerve and a steady foot, he is recommended not to attempt it ; the rocks are slippery, and the footing otherwise insecure.

The descent from Asparagus Island is most easily effected on the side nearest the shore, and here the assistance of the guides, who are usually found hovering about Kynance, is very useful. They lend a steady hand, and give directions, in the more difficult places, as to where the foot can 


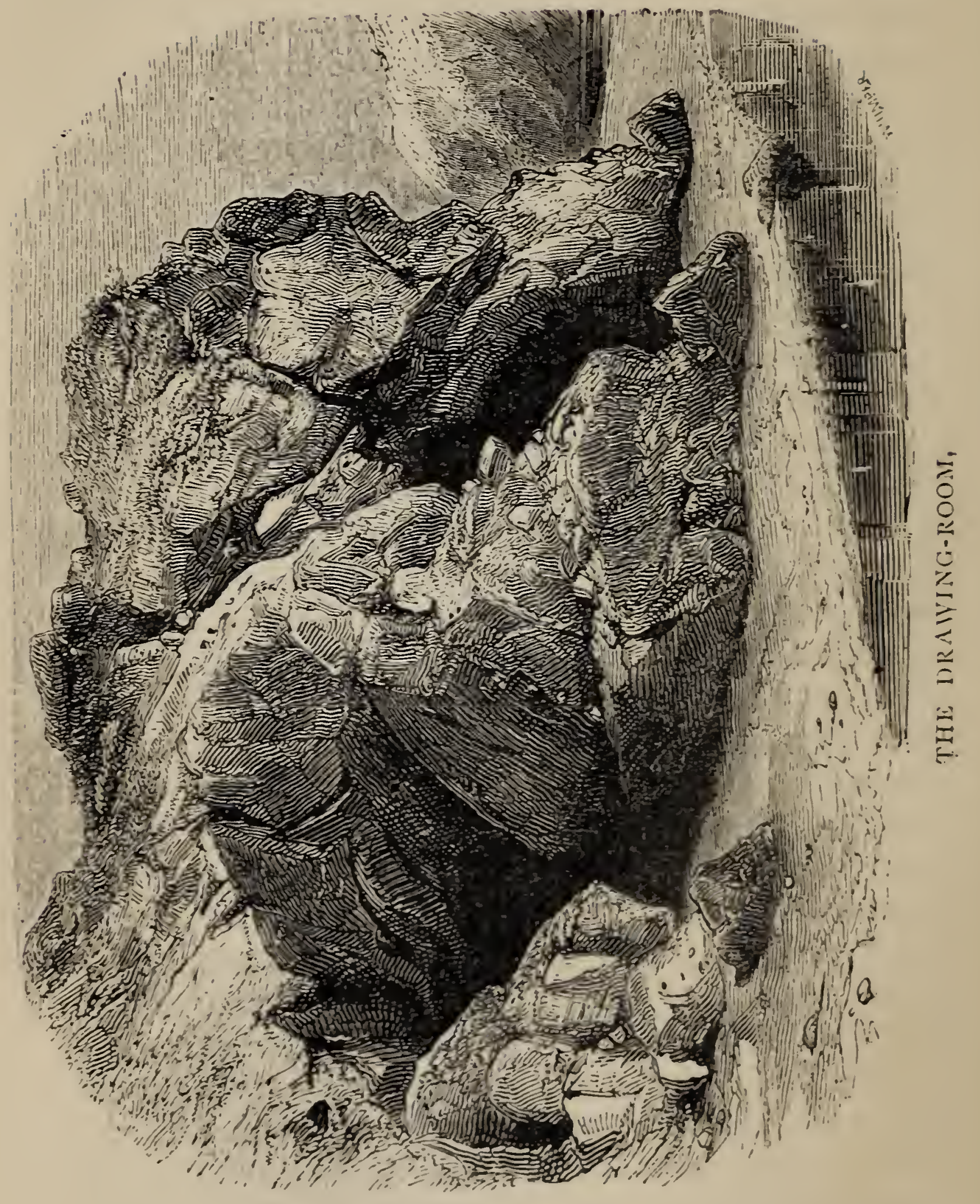


be placed with safety. A tolerably good climber, however, can make the descent with ease.

Our next step is to explore the caves which face Asparagus Island; they are remarkable not only for their size and picturesque carving, but for the beautiful colour of the rocks of which they are composed: black, white, green, yellow, and red, all polished by the action of the sea, and intermixed in endless variety, sufficiently account for the name of Serpentine being given to the formation. There are several mouths to the caves, but they all communicate internally, and as the floor is composed, in summer, of smooth sand, they may be explored without risk. The cave immediately fronting Asparagus Island is called the Parlour; that a little to the west, looking towards the Rill, is called the Drawingroom; but these names are sometimes interchanged.

The tourist must take great care that he be not here caught by the tide, for there is always a large area of sand here uncovered by the water, long after his return is cut off by the archway at the entrance of the cave, and he will find some difficulty in ascending the face of the cliff without the direction and assistance of a guide. In winter the whole of the sand is washed away, and the beach is then composed of huge polished stones; the archway is of course then much more elevated, and the caves are infinitely grander, though not so easy of access.

In the year I 846 Prince Albert ard the Royal children landed at Kynance, and by their kind condescension won for themselves golden 
opinions among the few of Her Majesty's loving Cornish subjects who chanced to be on the spot. The rock on which the Royal party landed will long continue to be pointed out as particularly interesting.

A person from an inland district visiting the sea for the first time, in moderately fine weather, could not fail, at the first glance, to be deeply impressed by the idea of boundlessness which it conveys; but he could scarcely imagine that the measureless plain before him was liable to as many changes in appearance as are frequently presented even during so short a period as a week. He might form in his own mind an idea, however imperfect, of the lashing roar of the waves when roused into fury by a landward tempest; but the possibility would never occur to him that the breakers could become so violent as to dash over the highest rocks at the Lizard, and, scaling the loftiest cliffs, to fall back exhausted, but undaunted, upon the succeeding billows. Yet I have stood on the cliff opposite Asparagus Island at Kynance, during a storm, and seen the waves from the right and left clash together between me and the island, forming a terrific mass of shattered water, so high and so dense, that I have for a time lost sight both of the island itself and the towering Gull-rock behind. To say that the foam was dashed into vapour, or that, in the intervals between the clashings of the waves, the sea beneath me was like a boiling caldron, are expressions which convey an utterly inadequate notion of the reality. At such times the very eyes of the spectator are overpowered; they 
cannot comprehend what they are called upon to behold, while the ears are filled with the unceasing roar of the battling elements. To make oneself audible to a companion standing at one's elbow, the voice must be raised to the highest pitch, and but few words occur to the mind as being meet for utterance. When the voice of the Lord is thus heard in its terror, the least presumptuous course for man to pursue is to listen in silence. Through the haze formed by the spray the distant headlands are dimly visible, white from their base to the summit, and huge balls of foam, worked into a compact froth, fly like living things up the face of the cliff, and scud away before the gale, sometimes dashed upon the ground and continuing their race in fragments, or soaring aloft and not alighting until they have traversed a distance of a mile or more, and sometimes wheeling in eddies into a ravine, which they fill up like drifted snow to the depth of many feet. This is a winter's scene, and consequently not often witnessed by the tourist. Its effects are most terrible at high spring-tides, and when the gloom of evening is approaching.

The other extreme is the dead calm of a cloudless summer's day, which only occurs after a continuance of fine weather both in the immediate neighbourhood and for very many leagues round. Not unfrequently it happens that a heavy surge is running at the Lizard, though the air has been still for many days before. This difference of condition between the two elements is to be attributed to the fact of a storm having taken place 
in a distant part of the ocean, and is thus accounted for:- When the sea is disturbed by the wind, the motion of the water does not extend to a great depth downwards, but is communicated laterally to an extraordinary distance. Thus, if we throw but a small stone into a smooth pond, it displaces a very small quantity of water, and sinks to the bottom without making any considerable disturbance of the water beneath; as we may infer from the very small quantity of mud which it raises: but the lateral disturbance is quite disproportionate to the size of the stone ; for a series of circles is formed on the surface of the water, which enlarge until they reach the sides of the pond in the form of little waves. Now the disturbance occasioned in the middle of a wide ocean by a violent tempest is on a large scale what the fall of a stone is in a pond. Huge circles of heaving billows continually proceed from a common centre, and agitate the sea over an amazing distance; they are not perceptible on a remote shore at the exact time that the storm begins, as they take some time to traverse a wide expanse of water; but, on the other hand, they continue to roll on long after the storm has ceased or has whirled away to some more remote tract of ocean; for even when the last circle has been sent forth from its centre, there are various exciting causes which keep the sea in an agitated state, such as opposing tides and currents, and the reaction of the wave from the shore. Besides, it has been ascertained that the wind during storms has a twofold motion, one circular, that is to say, in one spot blowing to- 
wards the nortn, then bending round towards the east, then to the south, and then to the west, until finally it returns nearly to the same spot from which it first began to move onwards; so that whatever part of the circle we take, the wind is there blowing from a point of the compass different from that in any other part of the circle. It does not, however, return exactly to the same point; for, meanwhile, the circle itself has been progressing bodily in a certain direction, leaving a calm where it had been most violent, and introducing tumult where its distant effects only had hitherto been felt. Thus, we often hear of a tempest having occurred in a certain district, the wind being from the north-east; and at another place a hundred miles off, it raged at the same time with the wind from the south-west. These two places we should therefore infer were at opposite points in the circumference of the same great circle. In intermediate places, probably, we should hear that the weather was scarcely stormy and the wind varying; or that a hurricane had visited them some time before or after, but blowing from a quarter different from either. ' A phenomenon analogous to this, but on a minute scale, we may frequently observe where an irregularcurrent of wind is produced by hedges or rows of houses. Dust and bits of straw are suddenly raised from the ground and whirled onwards in a circle, and presently all is still again. To a colony of minute insects the little whirlwind traversing the road is much the same as a tempest is to us.

Thus, on the shore of a wide open sea, where 
no land stretches out to check an impulse once given to the surface of the water, it frequently happens that while the air is still, the sea heaves in enormous surges and dashes with great fury on the rocks. Observed from a distance, it does not appear to be in motion, for the surface is not ruffled, nor are there any breakers, except when it encounters rocks, or an opposing tide; but vessels, though becalmed, labour heavily, rising and falling with a motion which to landsmen who happen to be on board is far more unpleasant than the tossing occasioned by a stiff breeze.

Experienced fishermen on this coast often discover, from certain appearances attendant on the swell in fine weather, indications of an approaching storm, many hours, and sometimes even a day or two before it arrives, and even prophesy from what quarter of the heavens the wind will blow. Sometimes the sea, as far as the eye can reach, is as smooth as a sheet of glass, just glistening sufficiently to show that its waters are subject to the motion of the tides. At such times, one may discern from the cliffs what is the nature of the bottom, sand appearing of a bright green, rock of a dark olive, and both colours mingling in the distance into a blue or grey which accords with the tint of the sky. From the cliffs, large fish may then be seen idling about the rocks; or, a little way out, shoals of mackerel or pilchards gambol about on the surface; if seen from a distance, detected by the rough appearance which they occasion in the water; but if near the shore, actually visible as they simultaneously rise and fling themselves. 
into the air, then suddenly sinking, and shortly reappearing, where perhaps one would least expect them. These shoals are frequently accompanied by flocks of gulls, which, unable though they are to dive, nevertheless have a quick eye and a never-failing clutch, so that while these fish are on the coast they enjoy many a rich banquet. In the latter part of the season gannets also follow the shoals. Their mode of fishing is different from that of the gulls. They soar aloft until they are exactly over the shoals, and suddenly fall, piercing the water with a splash, and disappearing until they have secured their prize.

Sometimes the shoals are pursued by enemies, natives of their own element. A troop of porpoises pursues them, rising now and then to the surface with a short asthmatic snort, rolling over their unwieldy bodies and again disappearing. More rarely, a company of huge grampuses comes into the bay, to the alarm not only of the fish, but of the fishermen, with whose nets they make sad havoc.

The shag, or lesser cormorant, an indefatigable fisherman, may be seen on the coast at most times. He carries on his employment in a way different from both that of the gull and the gannet. He is an cxcellent diver, stays below a long time, and when he rises to the surface, recovers his breath in a few seconds. The quantity of fish that he consumes is very great; when satisfied, he betakes himself (generally skimming with outstretched neck close to the water) to some sunny rock, where he spreads his wings to 
be dried in the sun, and remains perfectly still, until, having digested his last meal, he is ready to go in quest of another. If disturbed by any one within what he thinks a dangerous distance, he drops instantaneously from his perch, and disappears under the water: but if the intruder be at a distance which his experience has taught him to be safe, he takes no notice of shouting or clapping of hands, but sits still in supreme indifference. $\mathrm{He}$ is often seen fishing close to the rocks, and may, when the sea is still, be descried making his way under water.

Persons unused to coast scenery must not suppose that even during fine weather the sea always presents the same appearance. Far from this, every variation of wind, and every new arrangement of clouds, produce what artists term a different effect. The mere sinking of the sun a few degrees creates a change in the tint of the sea, greater distinctness of one cliff and dimness of another.

At one time, what little air is moving blows in the same direction with the tide; in this case the sea is smooth, and the set of the current is marked by lines like the tracks of carriagewheels : an hour or two after, the tide is running in an opposite direction, when the surface of the water is ruffled, presenting a different colour, and the tide streams off from the headlands in graceful lines of foam. If the wind freshens into a breeze, the sky remaining clcar, the sea assumes a deep blue colour, and every wave has a white crest, or, as mariners say, the sea is covered with "white horses." 
The places where there are sunken rocks are marked by sheets of foam, and over the insulated rocks which are slightly elevated out of the water, every billow breaks covering them with a canopy of spray, and immediately disclosing them decorated with miniature cascades. Wherever there is a sandy beach, long curling waves roll on in unbroken succession, sweeping. high upon the sand, and not retiring without an effort to collect what force yet remains unspent for a fresh attack on the shore. About one in every nine is more boisterous and sweeps higher than the rest: this the fishermen call "the death wave," a name which suggests the idea of some poor mariner escaping from a shipwreck, and carried back to a watery grave at a time when his struggles had placed him almost beyond the reach of his enemy.

The roaring of the sea on such occasions is continuous, but nevertheless partaking the character of the element from which it proceeds, falling upon the ear in waves of sound always loud, but nevertheless deepened at short and quick intervals, now and then almost overpowered by the sharp clash of a monstrous billow rising before it breaks against a projecting eminence, or emitting a deep sound like the roar of thunder as it bursts into, and is driven back from, some one of the numerous cavities in which the coast abounds.

In calmer weather the roar subsides into a gentle murmur, interrupted at long intervals by a sound resembling the explosion of a distant cannon, occasioned by the violent expulsion of air and foam through a narrow orifice from a 
cave suddenly filled by water which has risen through another entrance. So peculiar is this noise that I scarcely ever heard it without involuntarily raising my eyes to see whether there were not a vessel in the offing firing a signal-gun.

The hue of the sea on this coast depends principally on two combined causes, the state of the sky, whether clear or otherwise, and the state of the water, whether rough or calm. To these must be added the situation of the sun, whether before or behind the spectator; for one may stand on a headland with the sea on the right grey, but brilliantly reflecting the sun's rays, while that on the left reflects no light, but is coloured of the deepest blue.

Endless changes are produced by the passing of clouds, the shadows cast by which vary as much in tint as they do in shape. In the course of a few hours all the appearances which have been mentioned may present themselves, or there may be a mass of grey in front, with bright blue in the distance, or the reverse; the sky becomes overcast, and the sea inky; a troop of clouds passes over the middle distance, and the sea is apparently bounded by a dark line resembling an horizon; and if the line of separation between sea and sky be indistinctly marked, owing to the hazy state of the atmosphere, the vessels sailing in the sunshine beyond seem to be elevated into the sky. In sultry weather a mist frequently sets in from the sea and shrouds in an impenetrable veil everything but the dark cliffs in the immediate neighbourhood and the white line of foam at their base. 


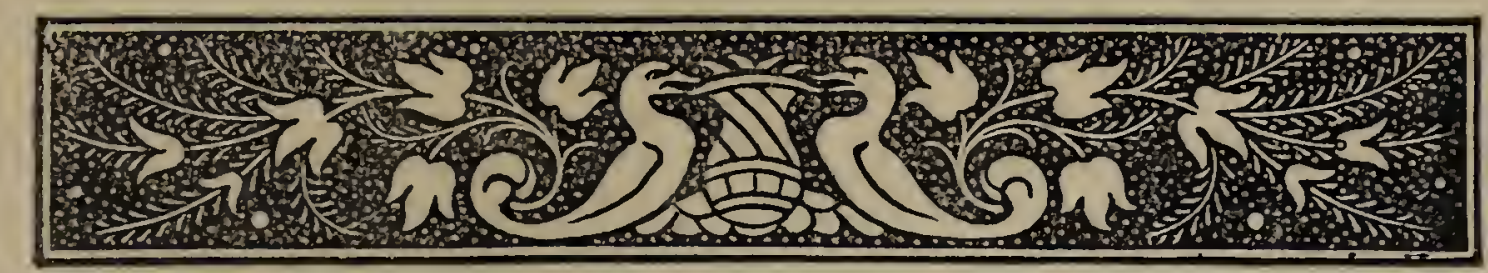

\section{CHAPTER III.}

Effect of air on Serpentine-rock-Calm near the verge of the Cliff in stormy weather-Sheep-stealers' Cave-The RillThe Apron-string-Botanical Scramble-The Horse and Horse-pond-Climbing for Gulls' Eggs-Pigeon HugoGue Graze-A Sea-mist-Soap Rock - Sheep-stealers Botanical Adventure-Steamer running ashore at Gue Graze.

THE ascent from Kynance proceeding westward is steep, but not difficult, and when we have reached the summit we shall do well to keep close to the edge of the cliff, for, though there is no pathway, the ground is unusually level and presents few impediments. It has been remarked that wherever the serpentine-rock is washed by the sea, as in the cove beneath, it presents a beautifully polished appearance; here, however, the masses of rock which protrude through the turf are remarkably rough, and of a brownish-red hue, almost resembling old, rustyiron. It is customary to speak of the Lizard district as consisting entirely of serpentine. But this is not the case. The Lizard Head, near Polpeer Cove, is mica slate ; and, generally, hornblende overlies the serpentine. Both rocks are much intersected with veins of granite, diallage, steatite, greenstone, \&c. In these intersections are to be found rare minerals, such as marmolite, retinolite, asbestos, noble 
serpentine, and jasper, \&c. In the granitic dykes nephrite occurs, formerly supposed to be found in Siberia and the Alps only. The geological hammer is necessary before we can discover the true structure of the stone. By chipping the rock, however, we detect the same admixture of colours in the newly-exposed parts, and conclude that the rusty hue of the exterior is occasioned by the decomposition effected by the oxygen of the atmosphere, and we may infer that the altered parts of the rock below the water-mark are successively worn away by the lashing of the waves. ${ }^{1}$

This being a very exposed part of the walk, if it should happen that a strong wind is blowing against the face of the cliff, it will add much to our comfort to be acquainted with the following fact:- Whenever a high wind blows directly against the face of a precipitous cliff, the obstruction which it encounters compels it, without exhausting its force, to take a new direction, and this is invariably upwards, for the simple reason that it is prevented by the sea or the rocks from proceeding downwards. Thus there is always, under these circumstances, a strong wind blowing up the face of the cliff. When this current reaches the verge of the cliff, it encounters another, which is pursuing a horizontal course from the sea. The two forces combine after an apparent struggle, and the practical benefit to the pedestrian is, that within a few feet of the verge of the precipice, the wind

1 For a fuller account of the geological structure of the dis. trict, see Appendix III. 
makes an archway over his head, under which he may walk in a comparative calm. If he thrusts his head beyond the edge he will feel a strong upward current, or if he throw over any light substance he will see it blown back and carried away over his head; if, on the other hand, he step a few paces backwards, he will encounter a current either beating downwards, or travelling on in its original direction. The distance of this covered way, from the verge of the cliff, varies according to the height of the cliff, its departure from the perpendicular, and the violence of the wind; but if the ground be such that he can choose his way, he will have little difficulty in securing for himself a sheltered course. But if a high wind be blowing either on his back or in his face, he must bear the whole brunt, and moreover proceed with great caution.

Somewhat about half-way between Kynance and the Rill is an almost inaccessible cave, which was formerly frequented by a desperate gang of sheep-stealers. It became generally known in the following way:-The lieutenant of the coastguard stationed at Cadgwith received a letter from head-quarters directing him to proceed with a party of his men and examine a certain cave, the exact position of which was described, information having been received that in it was secreted a large quantity of smuggled goods. After much search the mouth of the cave was discovered, almost concealed by a mass of fallen rock. Here the officer produced his letter, and having read it to his men, asked who would volunteer to enter first. No one replied. The 
entrance to this robbers' den was about two feet in diameter, and it was evident that if there were but one resolute fellow within, he might, armed only with a pen-knife, keep at bay a whole army. The officer, a man of dauntless courage, accordingly led the way himself, as indeed he had all the while intended to do, and was followed by his men. The cave, however, was unoccupied, and nothing was found but a sheep-skin and some scraps of leather, proving that it had been inhabited by a sheep-stealer, and by some one who chose to exercise here the business of a shoemaker.

The same gentleman afterwards related to me this account of his unsuccessful search, and another narrative connected with the spot, which I shall repeat by-and-by. He one day also took me to the place. We were obliged to scramble down the face of the cliff, which was composed principally of large loose stones, affording a very insecure footing, and when arrived at the bottom, he led me a short distance over the same kind of ground, until suddenly stopping, he said, "You are now within six feet of the mouth of the cave." $\mathrm{He}$ then pointed it out to me behind a mass of rock, and as I felt no inclination to accept his polite offer of going first, he lay down flat, with his hands above his head, and wriggled himself in. This uncomfortable posture I found, when I proceeded to follow him, was quite necessary, the aperture being too narrow to allow the arms to remain by the sides, and too low to admit of a kneeling posture. After a few feet of this serpent-like progress, I was enabled to stand upright, 
and found myself, to my great astonishment, in a lofty and extensive cavern, perfectly well-lighted by the rays of the sun, which were streaming in through a narrow fissure extending for many feet along the roof of the cave. We found no relics of former inhabitants, and I, having heard of the desperate character of its late tenants, did not care to explore the recesses. When we had seen enough we withdrew, assuming the same ignoble posture as when we entered, and I felt not at all sorry that it was now my turn to go first. Since the above visit I have often searched for the "Sheep-stealers' cave," but I could never discover it, nor, strange to say, have I ever since fallen in with any one who either could or would direct me to it. I have been informed, however, by a more successful tourist than myself, that the roof of the cave is now much lower than it formerly was, and that the fissure has been filled up. It cannot now be reached from land.

The bold headland, the Rill, which, while we were at Kynance, interrupted our view towards thewest, commands a glorious view of the Mount's Bay, of which, in its widest acceptation, it may be called the eastern extremity, the western limit being the promontory of Tol-pedn-penwith, near the famous Logan Rock, and Land's End. St. Michael's Mount, situated in a deep recess of the bay to which it gives its name, is distinctly visible if the weather be clear; and behind it, lines of white houses mark the positions of Penzance and of the fishing-town of Newlyn, the last place in the county in which the Cornish language was spoken. 
On the highest part of the Rill is a heap of loose, uncut stones, called the Apron-string, to which the following legend is attached. An evil spirit wishing to build a bridge across the channel to France, in order that smugglers might be enabled to bring over their goods without subjecting themselves to the risk of a sea-voyage, came hither with an apron-full of stones to commence the arduous undertaking. Unfortunately, however, he miscalculated the strength of his apron-strings, one of which broke under the weight; consequently the stones were all thrown out, and the architect in despair abandoned the enterprise. No doubt the stones were placed here by somebody, and a little examination will show that the lower ones are fixed in the ground in the form of a circle. Similar piles may be observed at Trewavas Head and near the Flagstaff at Cadgwith, and are perhaps remains of fire-beacons, or some other structures erected at a remote period for the purpose of communicating intelligence by signals.

Among the rocks under the Rill is one of the stations for the wild asparagus, which here grows large and ripens its seeds, as also for the finest specimens of the purple garlic ${ }^{1}$, a rare and beautiful species. In order to reach the spot where they grow it is necessary to pass by the pile of rocks in which the headland terminates, then to descend a short way, and to climb along under their base. On the last occasion of my collecting specimens here, after I had gathered as many as 
I required, I fancied that, instead of returning by the same way that I had come, the quicker and easier course would be to ascend the face of the rocks, which did not appear very difficult. Accordingly, with a good bundle of specimens in one hand, a stick in the other, and a fishingbasket containing geological and botanical apparatus slung at my back, I began to mount, choosing for my path a narrow strip of vegetation, with a wall of rock on either side. Arrived within a few feet of the summit, I found that I could not swing myself to the top of the last ledge without laying down my plants and freeing myself from the awkward protuberance at my back. This, therefore, I lifted up and deposited on the summit, and proceeded by the help of myarms to swing myself after. I effected my object without difficulty, but, alas! I unfortunately touched my basket, which was barely poised on the topmost stone, and away it spun, leaping from point to point, and making its way for the sea, at a rate that fishing-basket never achieved before. Luckily, however, before it reached the water its course was arrested by a projecting rock, and I, somewhat more deliberately, set out after it. Scarcely had I regained possession of it when I recollected that my carefully-selected specimens were unconsciously lying at the top of the cliff, and as I could not think of giving them up after the pains they had cost me, my only plan was to deposit my basket at the base of the steep pile of rocks, again mount within a yard of the summit, descend and return by the way I had come, my companion all the while waiting for me, 
and wondering at my insatiable appetite for asparagus and garlic.

Before we leave this point we must not fail to take a last look at Kynance Cove and the Lizard Head, for the view from this point does not yield to any on the coast. All visitors at Kynance should make a great effort to reach the Rill, however pressed they may be for time, and enjoy,

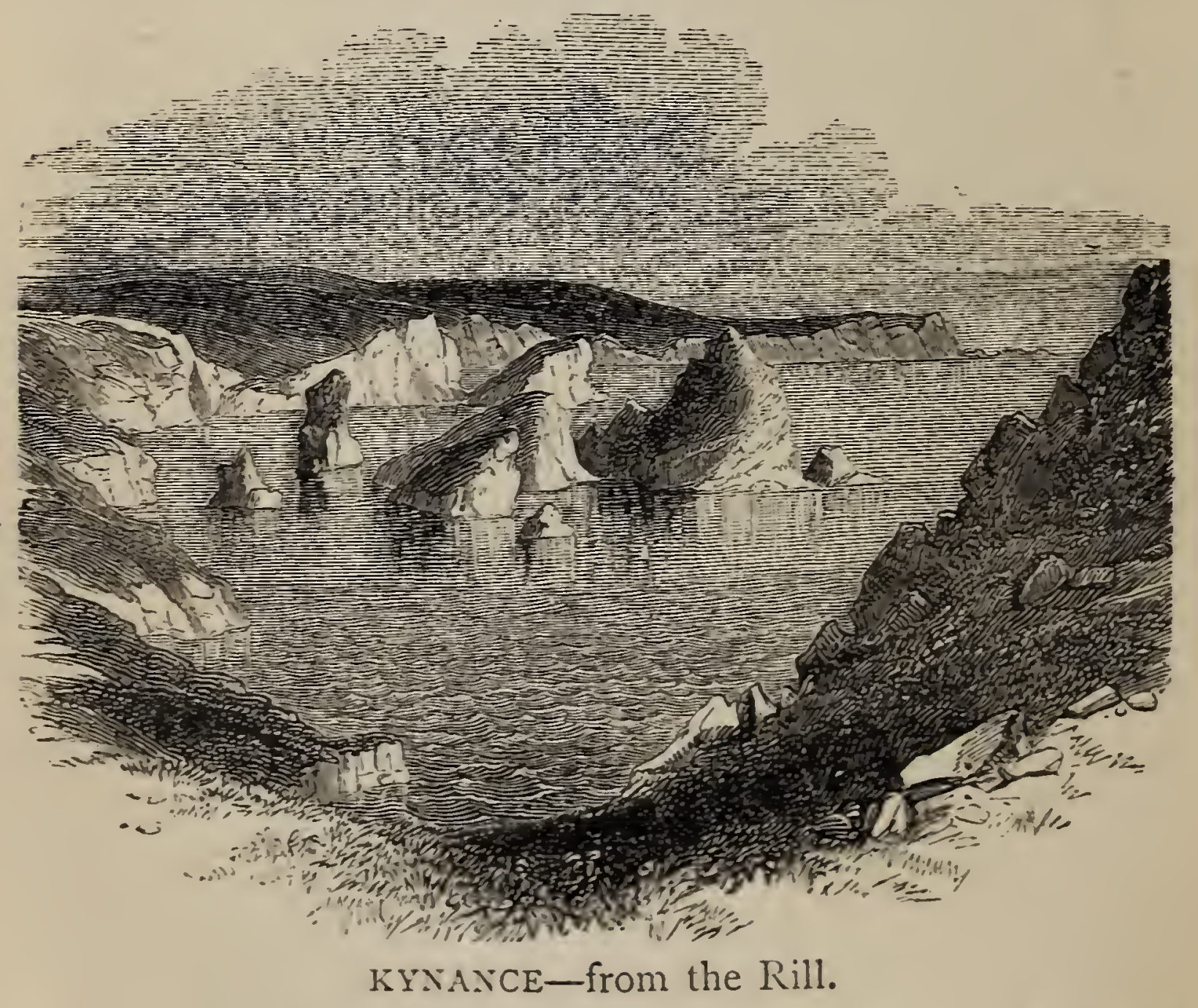

if even for a few minutes only, the splendid prospects which it commands both eastward and westward. The Soap Rock is, however, generally considered the great point of attraction in this direction, in their eagerness to visit which tourists frequently neglect the intervening coast; but if they follow the edge of the cliff the whole of the 
way they will be richly repaid for their trouble, and that without making any great sacrifice of time.

About half a mile beyond the Rill, a ridge of rocks runs out into the sea from the verge of the cliff, shaped like a saddle and terminating in an elevated peak. This is called the Horse. Though broad at the base, it tapers to so sharp an edge that to all appearance one might sit astride on it. It is far too dangerous to be attempted; for a single slip of the foot would be followed by cer-

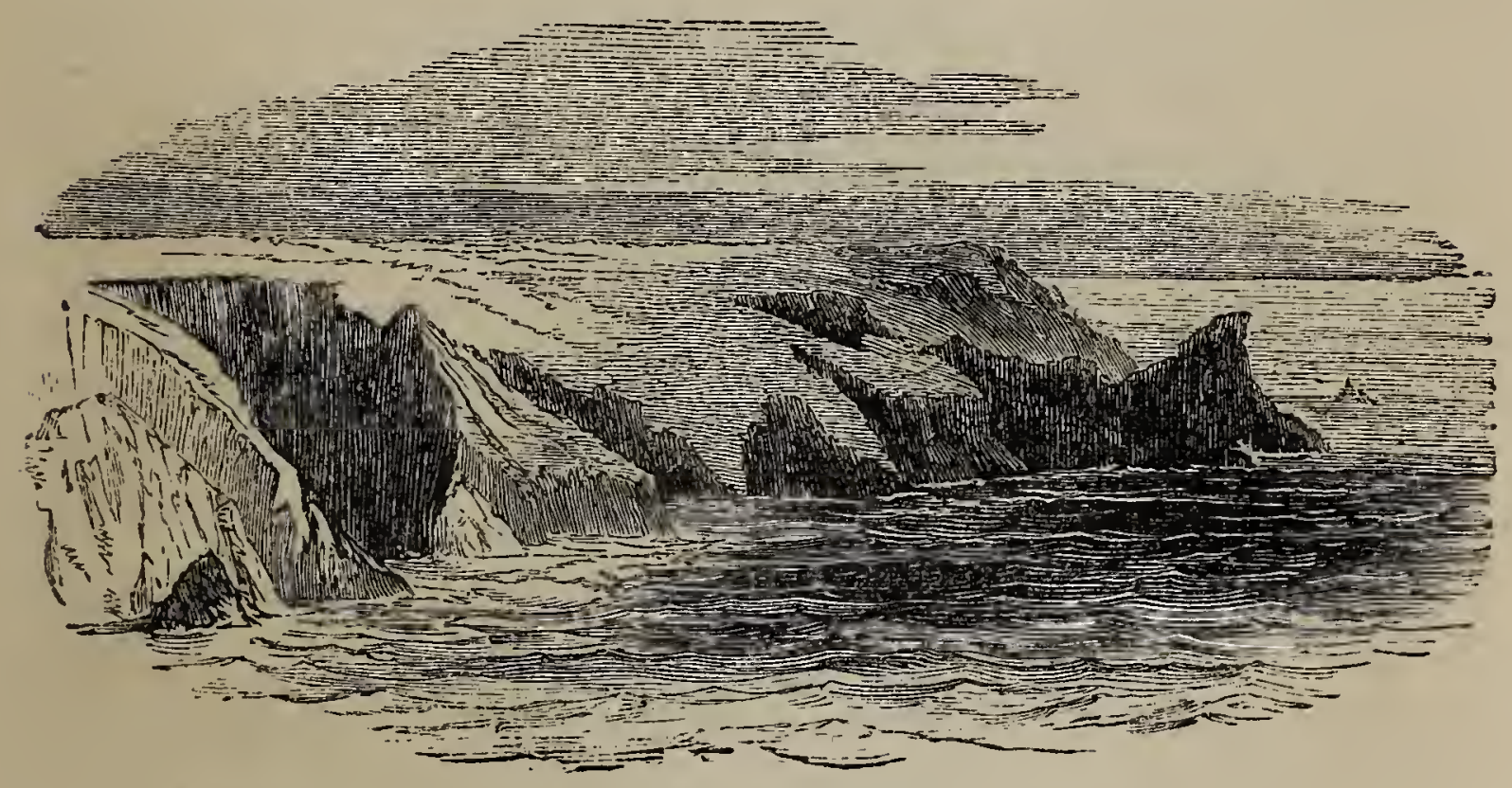

THE HORSE.

tain destruction. I was told that a gentleman out of mere recklessness had once attempted to reach the extremity, but before he had got halfway found that he could neither proceed nor return, and was consequently obliged to sit astride the rook until he was observed and rescued by some better climber than himself. A pilot from the Isle of Wight lost his life here a few years since while searching for gulls' eggs. Some of the people residing on the coast, who in the 
season partly gain their livelihood by searching for the nests of sea-birds, possess extraordinary skill and daring in this pursuit. The guides at Kynance will ascend the Gull Rock with ease, nay, rapidity, and for a trifling remuneration bring back eggs or young birds for any one who will employ them. If the following anecdote be, as I am assured it is, true, one scarcely knows whether the imprudence or presence of mind of these men is most to be wondered at.

A gentleman wished to have in his possession a living specimen of the chough, or Cornish crow, a bird which is now becoming rare, and which always builds in the precipitous sides of the cliffs. Two brothers engaged to furnish him with young birds from the nest. They accordingly provided themselves with a rope, and proceeded to a place which they knew to be frequented by these birds. One of them tied an end of the rope round his waist, and his brother lowered him over the edge of the cliff, holding the rope in his hand. When he had arrived opposite the nests, he found that they were built under an overhanging rock, so as to be beyond his reach. Nothing daunted, he set the rope a-swinging until he was carried into the hollow, when he held fast by the rock; but finding the rope too short to allow him to gain the nest, he untied it from his waist, climbed into the cavity, and secured his prize, which he stored away in his bosom. Meanwhile the rope had swung back to the perpendicular, and was resting motionless. Without hesitation he called out to his brother above, "Stand by the rope! I'm going to leap to it !" He did so; but the rope, as might 
have been expected, slipped through his hands, and he fell into the sea. The brother felt the jerk, and looking out over the edge of the cliff, saw him neither dashed in pieces nor drowned, but rubbing the water from his face, and exclaiming, "Carry my shoes round to the cove, brother John; I'll be round as soon as thee!" And so he was, and moreover bringing his birds safe with him. This perilous adventure is said to have happened in the parish of Breage.

The Horse stretches obliquely into the sea, and makes, with the mainland on the south, a semicircular basin, called the Horse-pond, the water in which has a remarkable inky hue, owing to the abundance of sea-weed which here finds a shelter in the projecting ridge. This used to be a favourite spot with the lobster-catchers, who rarely failed to secure a booty here, however unsuccessful they might be elsewhere. Of late years, however, it has lost its ancient notoriety. In the Horse is a cave which may be entered by a boat in calm weather.

Leaving the Horse we soon arrive at perhaps the most striking of all the minor features of the coast. The face of the cliff has been for some distance more or less rugged and shelving; but all at once this character is altered: the turf above suddenly terminates at the edge of the cliff, and by lying down and looking over we find that we are at the top of a perpendicular precipice about 250 feet high, the rock composing which is perfectly black, and the base washed at all times of tide by the sea. It is of small extent, and in shape nearlv a half-circle. 
One might imagine that a vast cylinder had descended and scooped out a piece of the cliff. A black rock beneath is generally frequented by a group of cormorants; and gulls and jackdaws innumerable find a safe retreat in its inaccessible walls. One may fling over a stone, and before

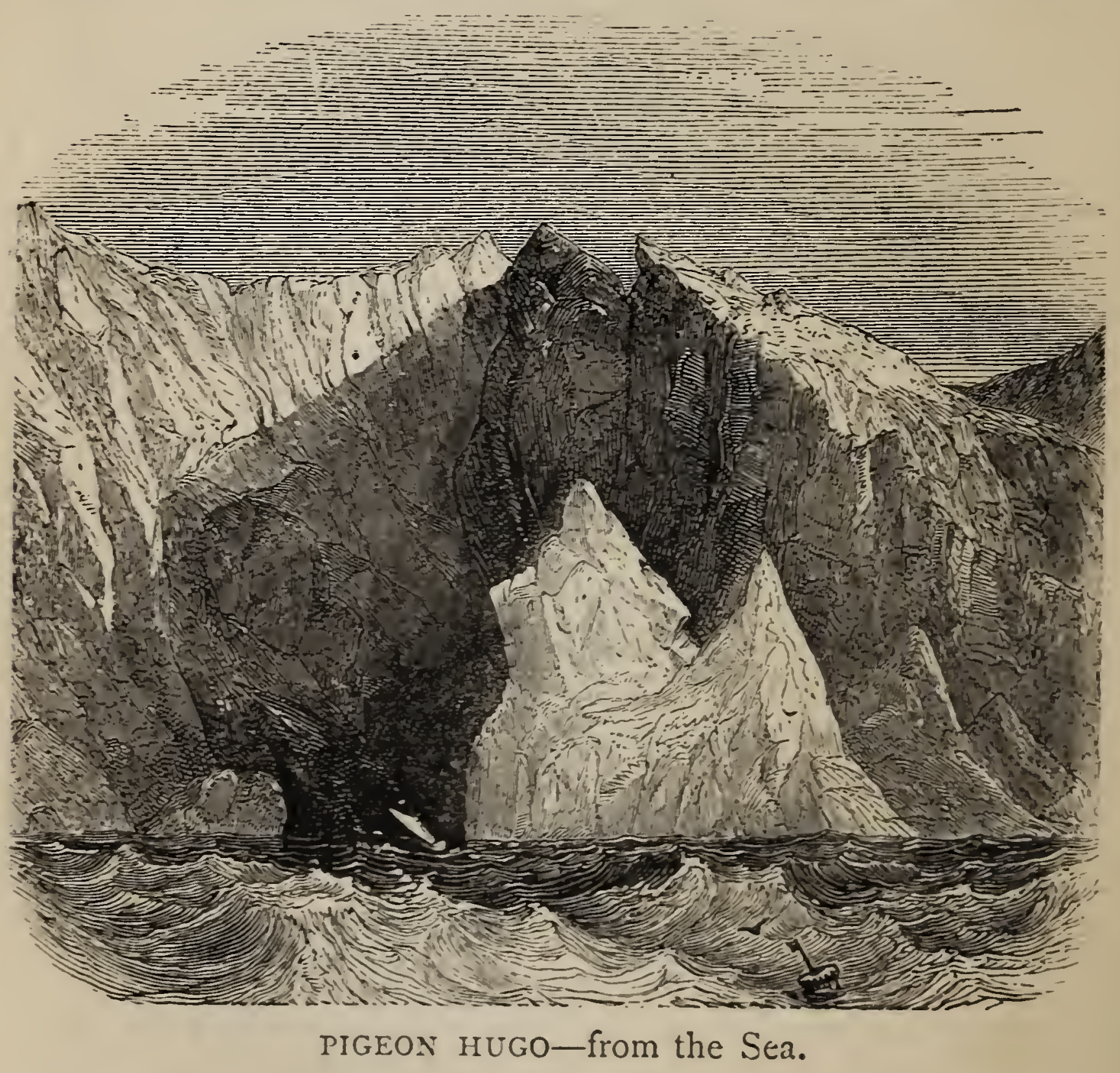

it reaches the bottom have plenty of time to lie down and see where it falls, and watch how the whole party of sober cormorants drop off into the sea like bullets and disappcar. Underneath there is a fine cave, Pigcon Hugo, said to be one 
of the most remarkable on the coast. Until within the last few years it was accessible from the land by a sort of pathway, which wound round the cliff some little way off; this has, however, fallen away, and it can now be reached only by a boat. I have many times contemplated a visit, but the landing is very dangerous, and only to be effected in the stillest weather, with the wind from the east, a combination of circumstances which has never fallen in my way.

A few steps further on we gain a view of the very remarkable cove, Gue Graze, as it is marked in the maps, or, as it is called by the people of the neighbourhood, Due Greze; in the ravine leading down to which is the Soap Rock. On one occasion of my visiting this spot the day was an exceedingly bright one in the beginning of July, the sun intensely hot, and scarcely a breath of air stirring. A long bank of fog had been for some hours stretching away in the extreme distance, but seemingly making no attempt to approach us. By the time, however, that we had reached the spot from which the annexed view is taken, the fog had lost its roll-of-lead character, and seemed endowed with a fantastic life : the part nearest to us appeared broken, and portions floated lazily along the bosom of the deep. Now, the whole sea was so far hid from our sight by a misty veil, that an occasional irregular dash of sparkling water alone betrayed what lay beneath; then, we might have fancied ourselves elevated miles into the air, and looking down from our airy post on the fleecy summer clouds. Now, portions of the mist would suddenly and 
unexpectedly melt, and we could see the clear blue water at our feet-a little way beyond, a wreath of thin vapour; then another strip of glittering sea, revealing for a few seconds a tiny fishing-boat-beyond, a dense bank of fog-yet further, a thin line of sparkling water, brilliant as a sun-beam, and beyond all, the grey Land's End cliffs, barred with narrow strips of shifting

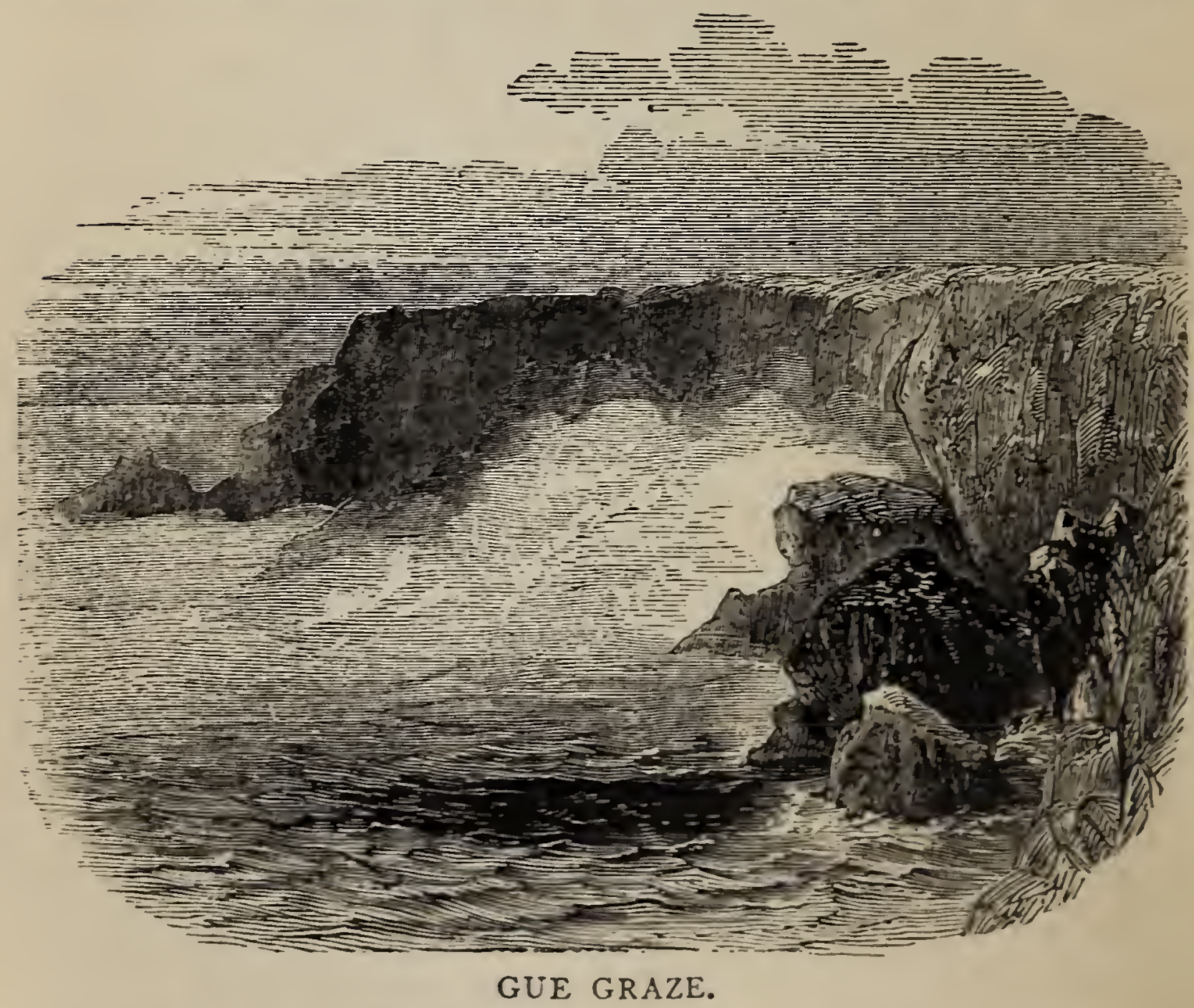

mist, like the lines of cloud which we sometimes see across the face of the setting sun. No vapour ascended to the spot on which we stood, nor were the crags on the opposite side of the cove at any time obscured. Only a light cloud of mist occasionally rolled in to the base, hiding the sea from view as well as the lower parts of the insulated 
rocks, the peaks of the latter emerging through it with remarkable distinctness. But what was most singular was this: that although the mist was constantly rolling up the cliff, it never reached the top; for when it was a little more than halfway up, it grew more and more transparent, until it disappeared; the reason evidently being, that the heat radiated from the sun-burnt rocks had raised the temperature of the air in their vicinity so much above that of the air which lay on the water, that the moisture which was condensed in the latter was rarified and became invisible the instant that it reached the warmer medium. The reverse of this is observed when a clear atmosphere is borne against the cold summit of a lofty mountain; in this latter case, the earth being colder than the air around causes a sudden condensation of the vapour which it contains, and produces the appearance of a fixed cloud, though a high wind may be blowing all the while.

The Soap Rock is situated in a deep ravine which runs down to this cove; it was formerly quarried, and large quantities of steatite, or soapstone, were carried away and employed in the manufacture of the finer kinds of porcelain. Of late years a material equally well adapted for the purpose has been obtained from the decomposed felspar, which is found in great abundance near St. Austle, and as this can be procured at a much less expense, the use of soap-stone has been discontinued. The only economical purpose to which the minerals of the district are applied is to the manufacture of Epsom Salts, for which a cargo is occasionally exported. There 
are some remarkable caves, called the Boulder Caverns, at Gue Graze, which will well repay a visit.

Gue Graze is connected in a melancholy way with the last deed of daring perpetrated by the robbers who formerly frequented the Sheepstealers' Cave near Kynance, described above. A shoemaker residing at the Lizard-town had lost a quantity of leather, which he supposed to have been stolen, though he could discover no clue to the offenders. About the same time a sheep was stolen from a farmer living at Helston ; and constables being set upon the track, traced the two men, brothers, who were supposed to have stolen it, to the Lizard-town, where they took up their quarters. Whether any private hint was conveyed to them, or whether they were led by their own sagacity to form the conjecture, they suspected that the thieves were secreted in the neighbourhood and supplied with provisions by their friends. This turned out to be the case; but by increased watchfulness they defeated this plan, and intercepted the provisions, until the men were compelled by hunger to appear near the village. The constables who were on the watch gave them chase, and cut them off from their retreat. Being hotly pursued across the Lizard Downs, they made for Gue Graze, where no doubt they hoped to secrete themselves, but were so closely pressed, that they could only dash into the water and swim for their lives, in the forlorn hope, it is supposed, of gaining their old haunt. Their pursuers had nothing to do but to stand still and 
watch them, and that task was not a protracted one. They soon saw one of the fugitives, who was still swimming outwards, sink; the other then turned, and attempted to swim back, but he had become so exhausted that he too sank before he had returned many yards. The circumstances connected with this sad affair are well known in the neighbourhood, and as it happened less than fifty years ago, there are perhaps persons yet alive who were acquainted with the parties concerned in it. The cave was of course well known to the rest of the gang before this event; but it was not until afterwards that people generally were aware of its existence. Some fishermen, it is said, who were passing by in their boat saw a fox disappear in a mysterious manner, and had the curiosity to land and see what had become of it. Discovering the narrow entrance to the cave, they went in and found parings of the leather stolen from the village, some sheep-skins, and a quantity of mutton bones, which gave conclusive evidence of the character of its late occupants.

Two men supposed to be connected with the same gang, some years previously to this, lived in a rude cabin near the Dry Tree on Goonhilly Downs. They happened to hear that a certain farmer would return from Helston one marketday having on his person a considerable sum of money. They waylaid him in a lonely part of the road leading to Mullion. Just at the time that they expected their victim, some one passed by on horseback, at whom they fired, but missed their mark. Shortly afterwards the real victim 
rode up; one of them fired again, the shot took effect, but it was not without some resistance that he was dragged from his horse. The villains made off, secure, as they thought, from detection. The wounded man, however, was found soon after and conveyed to a neighbouring house, where he expired the same night, but not before he had made deposition, that he did not know the persons of his murderers, but that his horse had stepped on the foot of one of them in the struggle. This simple circumstance led to their discovery; they were apprehended, and forfeited their lives on the scaffold. But a truce to these tales of horror, or my readers will be afraid to stay out the week with me; so I will change my subject at once, and relate a story of an entirely different kind, namely, my first botanical adventure in Cornwall.

On the 24th August, I83 I, I happened to be residing in Helston, and having heard a great deal of the beauty of the scenery of Kynance Cove, and of the rare plants which grew on the rock there, I determined to see for myself whether the accounts which I had heard were true. Accordingly, without companion or guide, I started at eight o'clock in the morning on what proved to be my perilous expedition. The weather was unpropitious; there was a good deal of wind stirring, and rain seemed to be impending. The rare occurrence of a holiday, however, and the hope of gathering with my own hands, from their native haunts, a number of plants which I had only heard of, or seen in the herbariums of the curious, encouraged me to proceed in spite 
of all adverse circumstances. My equipment consisted of a walking-stick, a folio book for drying specimens, which was slung over my back, a packet of sandwiches, and a small flask of brandy. Why I am thus particular in my inventory will appear by-and-by. After loitering by the way to collect and examine specimens of several plants then new to me, I found myself about mid-day drawing near the coast. The first point that I arrived at was the head of a valley, which appeared to answer the description I had received of Kynance, and making my way down with what speed I could, I soon found myself in that cove, as I imagined, though, as I afterwards found, I was mistaken as to the locality. The tide was out, as I expected; I accordingly began at once to explore for Asparagus Island, which, with the imperfect description I had received, I had no difficulty in recognising in a high detached rock to the right of the cove, the top of which was covered with vegetation. I soon climbed to the summit in search of asparagus, but failed, for the simple reason that it does not grow there. I was, however, well pleased to discover the tree-mallow, which I had never before seen growing wild. A few specimens of this I secured and laid out in my book to dry. All this nccupied some time, and on my descent I found that the tide had begun to flow, and that my retreat to the cove was cut off, unless I chose to wade through the water to the depth of a foot. I quietly took a survey of the cliff, and seeing that it was (as I imagined) easy of ascent, I thought I need not be in a hurry, but might as well rest 
myself after my eleven miles' walk, and discuss my sandwiches. This done I began to mount the cliff, and at first made a rapid progress, there being plenty of grass as a holdfast for my hands, and of loose stones among which to insert my feet. But when I had ascended some sixty feet, I found myself stopped by a slanting sheet of polished serpentine, on which I could gain no footing, though I made several attempts. I accordingly descended with the intention of making a trial somewhere $\in$ lse, and proceeded yet further to the right. But here I found myself entirely at fault, the sea having come into the very base of the rocks, which were perpendicular. My only alternative was to turn back and regain the cove by wading through the water. I found, however, that I had spent so much time in my ineffectual effort to scale the cliff, that the tide had risen considerably, and I could not now attempt to ford a passage without incurring great danger, and reluctantly came to the conclusion that I was in an awkward predicament. The tide had still four hours to flow, so that I should of course be detained ten or eleven hours. To add to my discomfort, it seemed to be on the point of raining; and recollecting with what difficulty I had found my way out by daylight, I could not lose sight of the fact that it would be yet more difficult to find my way home by night. Yet I had nothing to do but to sit still and wait, a task which I tried very hard to perform, and took from my pocket Johnson's "Rasselas," in the hope of whiling away the time. I soon found that the "History of a Search after Happiness" 
was little suited to the frame of mind to which I was then subjected, and quickly shut my book. As for sitting idle, it was quite out of the question; so I again climbed the island to explore, but discovered nothing to justify the hope of improving my condition. The only point where there appeared the least probability of the ascent being made by a human being was that which I had tried and found impracticable. I again descended, scrambled over the rocks to the right and left as far as the tide would allow me, sat down, and endeavoured to compose my mind. Danger there was none, the island being large enough to afford refuge to a hundred men, and I knew very well, from the character of the vegetation on the summit of the rock, that it was never swept by the sea, even in the stormiest weather. An hour and a half I spent in this way, and at last, in spite of all my efforts, had worked myself up to such a pitch of excitement, by picturing to myself the misery of sitting ten or eleven hours in the rain, climbing over the rocks in the dark, and finally groping my way over an unknown country, with whatever vigour of body and mind that I had possessed exhausted, that I resolved to make a fresh attempt where I had before been unsuccessful. I recollected, that when I made the first trial, I thought there were many other ways of ascending, and that I might therefore have been deterred by difficulties which in my present emcrgency would not seem so formidable. I accordingly bcgan the ascent a second time, and in a bolder spirit. When I reached the shelving mass of rock mentioned 
above, I stopped to take breath, and to meditate once-more whether the Fersonal inconvenience of spending the night on the spot, and the anxious suspense which my absence would occasion my friends, were sufficient to weigh against the risk I might incur in persisting in my attempt. I had all but decided on returning, when I observed a small stone in a crack of the rock, which appeared to be loose; this I removed, and thus obtained one footstep, but not being satisfied with my precarious footing, resolved on desisting at once. To my utter horror I found this to be impracticable. The book which I had slung across my back so impeded my movements, that when I attempted to turn, the corner pressed against the cliff and forced me outwards, and had I persisted, would inevitably have precipitated me to the bottom. I could not retain my posture for any length of time, resting as I was on one foot, and being obliged to hold fast with one hand in order to do even that; my only alternative was to proceed, but whither, I knew not. By occasionally making use of my stick to loosen some stones, and to try the strength of others, which frequently peeled off from the rock with a very slight pressure, I contrived to approach within eight or nine feet of the top. Here, however, I found myself in a situation in which few I believe have ever been placed, except in the most terrific dreams. I had gradually quitted that part of the rock which hung over the sloping grass; I had inserted the end of my stick in a crevice, and, being obliged to use both hands in clinging to the rock, I could not draw it out, and if my foot had slipped I should 
have glided over a few feet of smooth stone, and then fallen seventy or eighty feet, whether into the sea, or on the shore, I could not turn my head to examine. To add to my distress I found my book much in my way; I was supported almost entirely by the muscular strength of my fingers, and a mass of apparently loose stores projected over my head. These I must surmount; but

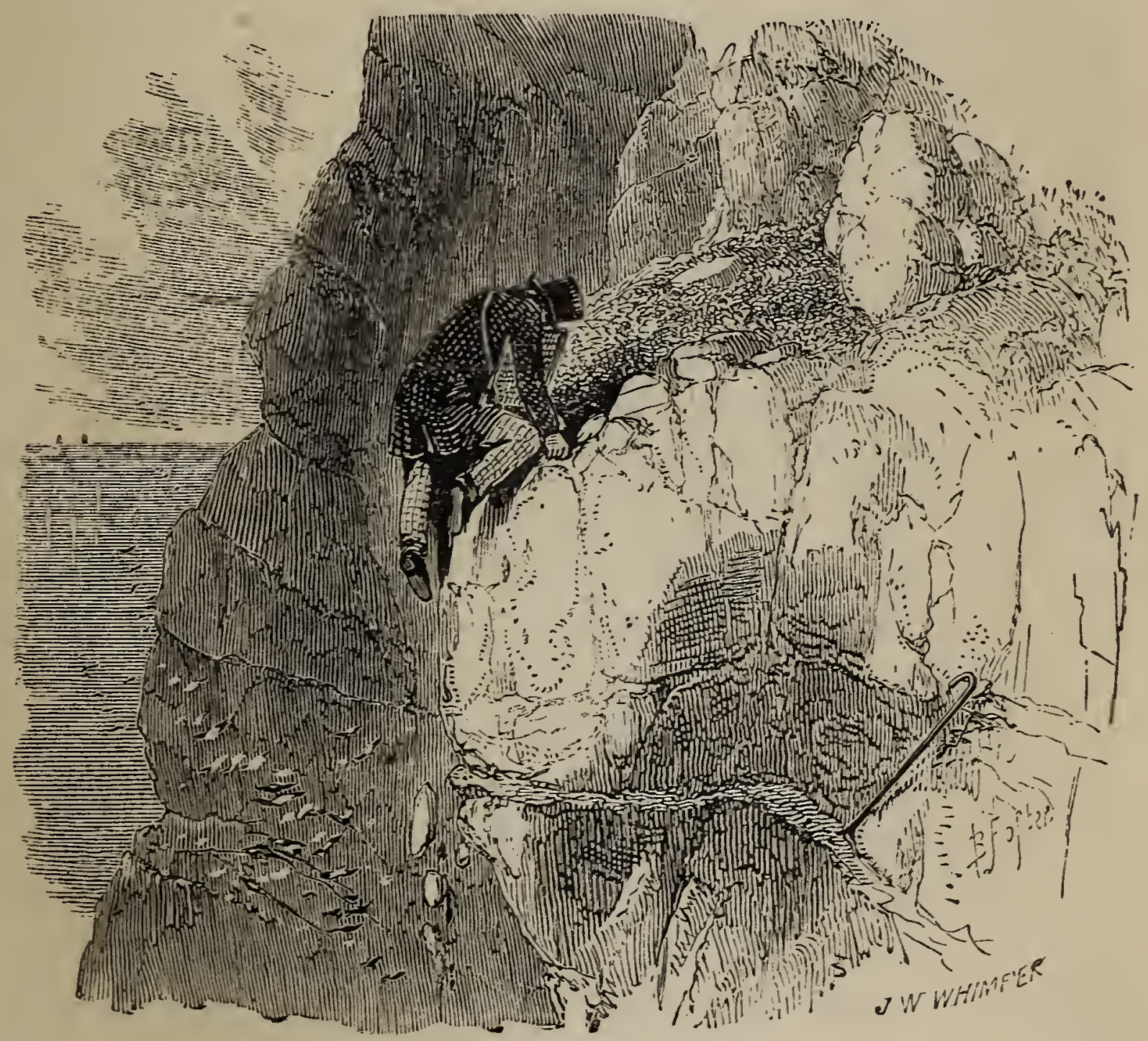

how? The only possible support for my feet was six feet below the summit of the rock, and not more than half an inch wide. I managed with great difficulty to set my foot on this, snatched at, and caught hold of, the top of the rock with the ends of my fingers, and was suspended as it were between heaven and earth directly over the precipice, when-the ledge 
under my feet gave way, or my foot slipped (terror prevented me from observing which)with strength more than natural I clung by my hands alone-I feit a shudder pass through my frame-my blood seemed to stagnate-and a spontaneous agitation of all the nerves in my body commenced, so violent, that this new horror now took possession of me, that the involuntary motion of my hands might loosen my hold. During what appeared to me a long time, but what I dare say was, in reality, less time than my readers take in following my description, was I in this state, dangling my feet on every side in search of a resting-place, and dreading lest the stones to which I clung with my fingers should give way. Feeling that I could hold no longer by my fingers, I made a violent effort, and planted my knee, I know not how, just be-. low my hands. Still I was not safe-I was now balanced on my hands and one knee on the edge of a cliff-one leg was still hanging over, idleand my book, which I had not had the means of getting rid of, had slipped round in front, and inserted itself between my body and the rock. By dint of another effort, however, I contrived to throw myself forward, and was safe! But, alas! I had not yet reached the top, I was scarcely half-way up; but I was resting at full length on a plot of green turf-the scene of as earnest thanksgiving as had ever been poured forth from my heart-and though I was for some time in such a state of nervous excitement that I dared not look down, much less venture to move, yet the consciousness of imminent danger was gone, and with it all anxicty. Still 
my limbs were in a trembling state, my tongue was glued to my palate, and though I tried to swallow a little brandy, my throat refused to perform its office; all that I could do was to rinse out my mouth, and to long, as earnestly as a traveller in the desert, for a draught of water that I might do so effectually. I had not even yet accomplished all my task; a large portion of cliff still remained to be surmounted, scarcely, if at all, less precipitous than that which I had traversed. I was resolved, however, to run no more risk, and sat down calculating the probabilities of my being seen and rescued on the next day by a large party, who I knew were coming hither for a day's enjoyment from Helston. After resting a little while, though I had not yet mustered sufficient nerve to look dowr, I began to explore my position, and saw behind me a low but steep rock, which not being very difficult I ascended, and to my infinite joy discovered just before me a pathway worn by human feet, leading by a circuitous route from some part of the coast now covered by the sea to the summit of the cliff. It may readily be supposed that I was not long in reaching this. I ran, as well as the nature of the ground would permit, and soon reached the top; and now that I once more had the power of walking on level ground, all that I had before experienced seemed a dream; but the roaring of the waves beneath me, which I dared not, even then, look down upon, the quivering of my limbs, and, above all, the tears of grateful emotion which involuntariiy rose to my eyes, soon convinced me of the reality of my situation, and of my perilous expedition. 
A short time after I had left the coast it began to rain, and continued till I reached home, between six and seven o'clock, drenched to the skin.

The above narrative I committed to writing the day after my adventure, and I believe it to be the reverse of an exaggerated account. I have, since, several times tried to discover the precise spot, but have never been able; not because I do not, even now, retain a distinct recollection of the scene, but because, on all parts of this coast where the structure of the rock is not unusually compact, a continual change is going on by the wearing away of the surface, and by the fall of large masses; and, to tell the truth, I am so little desirous of a repetition of the feat, that I have been very careful not to tarry long enough in the vicinity to make a full examination, lest I should find my retreat again cut off. ${ }^{1}$

A word of advice to climbers. It is much more difficult to descend than to ascend the face of a precipitous cliff, and, therefore, less dangerous; and again, it is much easier to ascend a place of the same character than to descend, and, therefore, more dangerous. This will appear to be a paradox, and on that account it will, I hope, be remembered; but nevertheless, experience will prove that the maxim is a sound one. A climber, in descending, instinctively strinks from climbing down any places where his body would be likely to be thrown off its balance, unless he can secure a firm footing and

1 On the 8th of August, I873, forty-two years after this adventure, while sauntering round the coast, I unexpectedly lighted on the exact spot where I made my perilous ascent between Kynance and the Rill. 


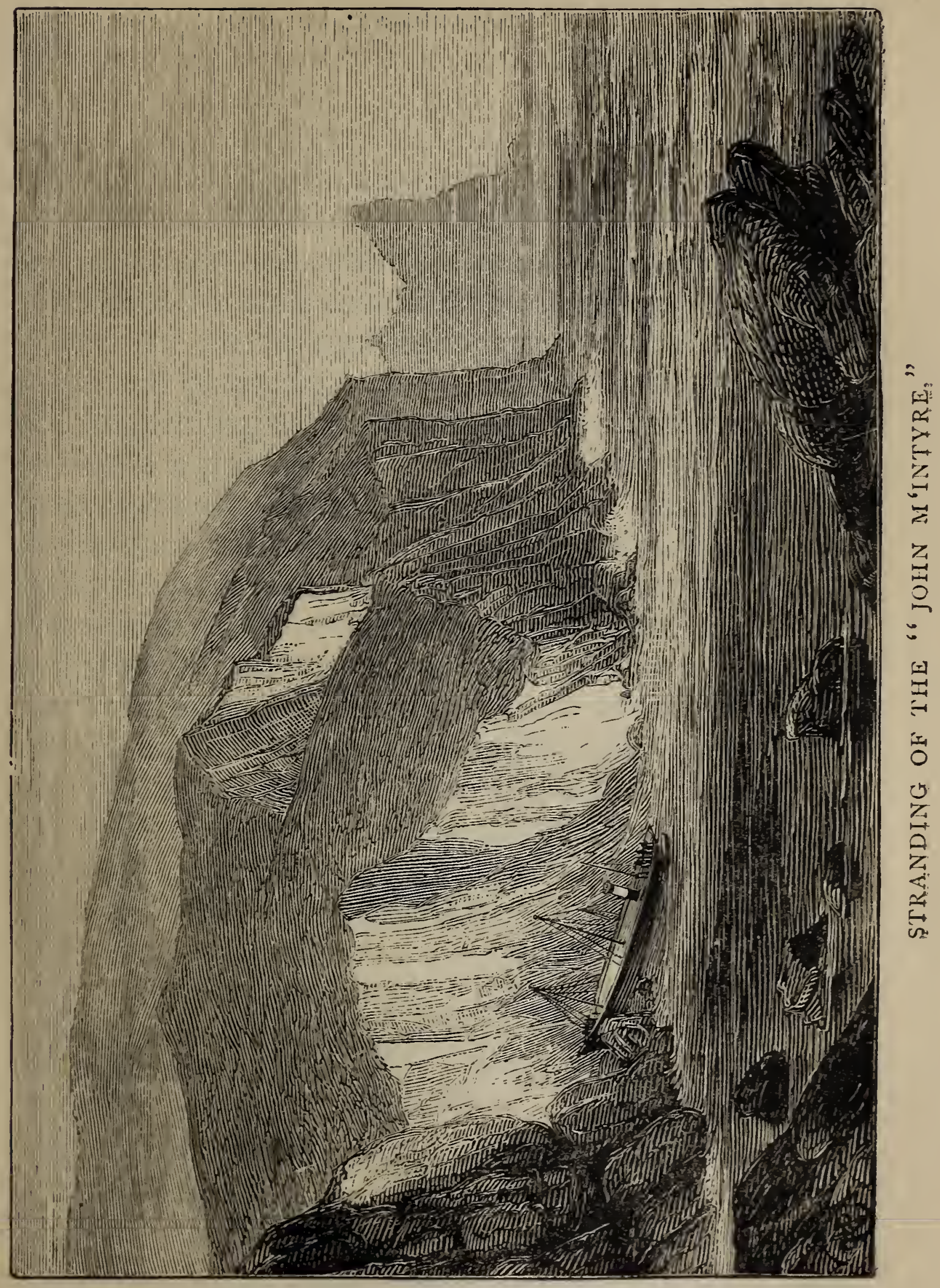


a good holdfast for his hands; and if he reaches a spot which is impracticable, he can make sure of being able to return by the way he came. On the other hand, in ascending, his body is thrown forward, he can see the nature of the rock which he is climbing, and has a far greater command over his hands and feet; in addition to which he is not likely to become giddy, for there is no necessity for him to look down. But if he arrives, after some laborious climbing, at an impracticable spot, and wishes to return, he may be called on to traverse a dangerous piece of ground, which he scarcely noticed during his ascent, a sloping, smooth rock for instance, or of slippery turf, where, if he loses his balance, or his foot slips, the result must be most perilous. As a deduction from this, let him also bear in mind, that when a descent has been made with much difficulty, he had better return by the same route rather than attempt another which only appears to be easier. He may be tolerably certain that where he got down, he can get up; but if he tries the new route, he may be brought up by some difficulty which he could not descry from beneath, and be compelled to return by a more perilous way than the first, and, after all, expend his labour in vain.

On the I7th of April, I865, there occurred at Gue Graze an incident unparalleled perhaps in seafaring annals. The Joln McIntyre, a large iron steamer in ballast, proceeding from London to Wales for a cargo of coals, suspecting no danger and fearing no calamity, received a sudden shock off the Lizard. She had touched a sunken rock, but was soon got off and pursued her course. No damage was visible, but it was 
soon apparent that she was taking in water rapidly. The captain, losing no time in idle examinations, wisely forged ahead, and being well acquainted with the coast, determined to make for Mullion Cove, and run his vessel aground. He passed the Rill-passed the Horse ; water was rushing in too fast for the pumps to produce any sensible effect. In twenty minutes Mullion Cove would be reached; but in ten minutes the John M'Intyre would cease to float. "Keep her at full speed. Hard a port! Steady!" And the still obedient ship charged straight at the beetling cliffs. The helmsman knew not where he was going, but he had faith in his commander, and, watching the movements of his extended hand, turned the vessel sharp round into Gue Graze. Still at full speed, the ship struck a rock ahead, which, from the combined effects of her weight and velocity, split as if it had been wood, and she lay high and dry on the beach. The officers and crew landed in safety, and secured all their valuable effects. The owners and Lloyd's agents, informed of the catastrophe, lost no time in sending down competent workmen. The weather continued fine, and the spring tides were ten days off. During this interval, at the suggestion of a villager, Dionysius Williams (to whom I am indebted for this narrative), the hole in the ship's bottom was stopped with bags partially filled with clay brought from Kynance, the water was pumped out of her, and she was hauled off and taken in safety into Penzance. 


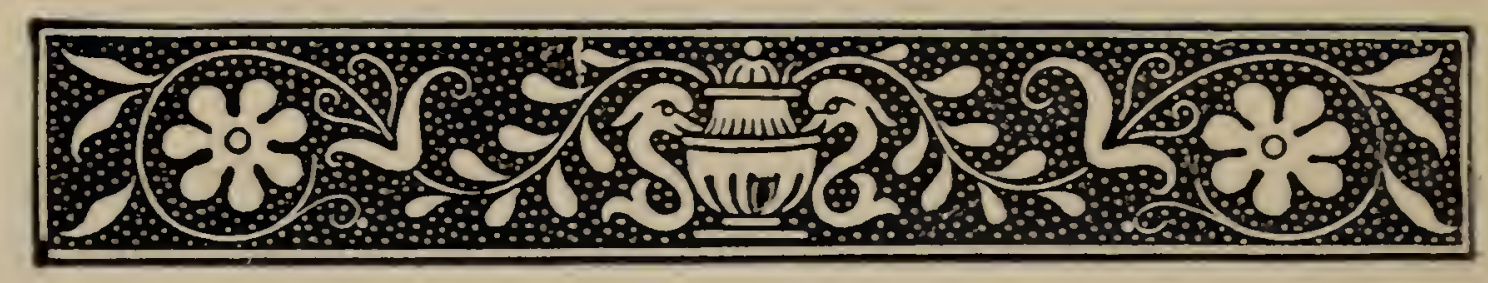

\section{CHAPTER IV.}

The Balk-Ravens' Hugo-Dolor Hugo-The Frying-panCadgwith-Saint Rumon-Conflict between a Man and a Conger-Sunfish - Ynys-head - Poltesco-Kennack CoveGround Stine-Sting-fish, Red Mullet, Turbot-The Blackhead.

RESUMING our survey of the coast at Penvoose, it becomes necessary that we should take boat, in order to explore the most interesting objects. which here present themselves. The expedition is attended with no danger, provided that the sea be quite calnı: otherwise it is so perilous as to be impracticable. The fishermen, indeed, proceed to sea when the weather is very stormy, but their occupation takes them to a distance from the shore, whereas our track lies along the base of the cliff; and in order to see to advantage the natural curiosities of this portion of the coast, we must approach to within a few feet of the rocks, or even land on them.

Proceeding in a south-easterly direction, we pass under the Balk, a lofty cliff which terminates in a peaked mass of rock, and the face of which is precipitous from the falling away of the loose stone. A winding path on either side leads 
down to a sandy cove, and here may be found some of the most beautiful varieties of serpentine spotted with bright red and spangles of diallage. Stone of the same character runs inland to a considerable distance, and frequently crops out to the surface. Masses have been taken from hence, and made into pillars, chimney-pieces, \&c., for which purposes it is well adapted, from its not being so liable to crack as some of the other varieties. But to the geologist no spot on the coast will be more interesting than Polbero Cove, where serpentine, hornblende, and diallage are associated in a small cavern, which can be approached at low-water only. This was the place where the ill-fated Brest was wrecked in I879.

One cannot go more than a few yards in this direction without opening on a fresh view, so indented are the cliffs, and so fantastic the rocks. Under Carn-barrow, a projecting rock makes a natural archway, through which a boat may be taken with safety if the sea be calm. A little further on is Ravens' Hugo, situated in a narrow recess. This is not an imposing cave, but is pointed out by the coast-guard men as worthy of note from the fact that a large number of kegs of contraband spirit were once discovered in it. The landing is difficult, and is effected on a rock, the substance of which closely resembles lava, and thus affords to the geologist strong indication of the volcanic origin of the district. The entrance into the cave is narrow, and is scarcely washed by the sea, as is evident from the luxuriant sea-ferns ${ }^{\text {? }}$ 
hanging like tapestry round the orifice. The boatman told us that a party were once landing here, when a fine young man, a sailor, slipped from the rock, and though his companions used the greatest efforts to rescue him, he was drowned almost, one may say, within their hands. At a considerable height above the mouth of the cave is a niche in the rock, such as are employed in architecture to receive images. Here from time immemorial a pair of ravens have annually built their nest and reared their young ; from this circumstance the hugo or cave takes its name.

At no great distance beyond the Ravens' Hugo is Choughs' Hugo, under a point named Penballo. Still further on is another cave, the lower part of which is entered by the sea at all times of tide; it is therefore only accessible by a boat, and not even thus, except when the water is quite still. The usual method is to back the boat, the men sitting at their oars, and prepared to pull out again with all speed in case a wave should suddenly roll in. It is marked in the maps Dolor Hugo; but the name is pronounced Dollah Hugo. Of all the caves that I have ever inspected, this wears the most perfect air of mysteriousness and solemnity. At the entrance it is large enough to admit a six-oared boat, but soon contracts to so small a size that a swimmer alone could explore it, although no one, so far as I have heard, ever ventured to perform the feat. Its termination is lost in gloom, but as far as the eye can discriminate, the water is unceasingly rising and falling with a deep murmuring sound, which is reverberated from a great distance, and 
falls on the ear with a most imposing effect. The colouring of the rocks at the entrance is magnificent. The base is of a deep rose-pink; the sides rich dark-brown, with blotches of bright green and rose colour; the roof purple and brown. The water is very deep and of a fine olive-green, and, being remarkably clear, the light stones lying at the bottom are distinctly visible, among which, on one of my visits, we could descrygreat fishes, probably basse, pursuing shoals of launces. The accompanying sketch, hastily taken on the spot, gives a far better idea of the cave than I could have supposed possible without the aid of colouring. When tourists venture in hither, which is not very often the case, a favourite practical joke of the boatmen is, to secrete a loaded pistol, and without giving previous intimation, to fire it off. The effect is terrific; the noise seeming to come from the inmost recesses of the cave, from its sides and roof ali at once, and exaggerated a thousand-fold by the reverberation. Any one, thus taken by surprise, could scarcely account for the sudden and protracted roar on any other supposition than that the whole line of cliff was visited by some momentous convulsion of nature, and was tumbling into ruins. To a person forewarned, the uproar resembles a terrific thunderclap bursting about his head.

Proceeding yet a short way further towards. the north-west, our useful little boat is abruptly turned towards the cliff, and we pass under a natural archway of parti-coloured rock, and quietly land on the nost singular beach existing on this, or perhaps any other coast. From the 


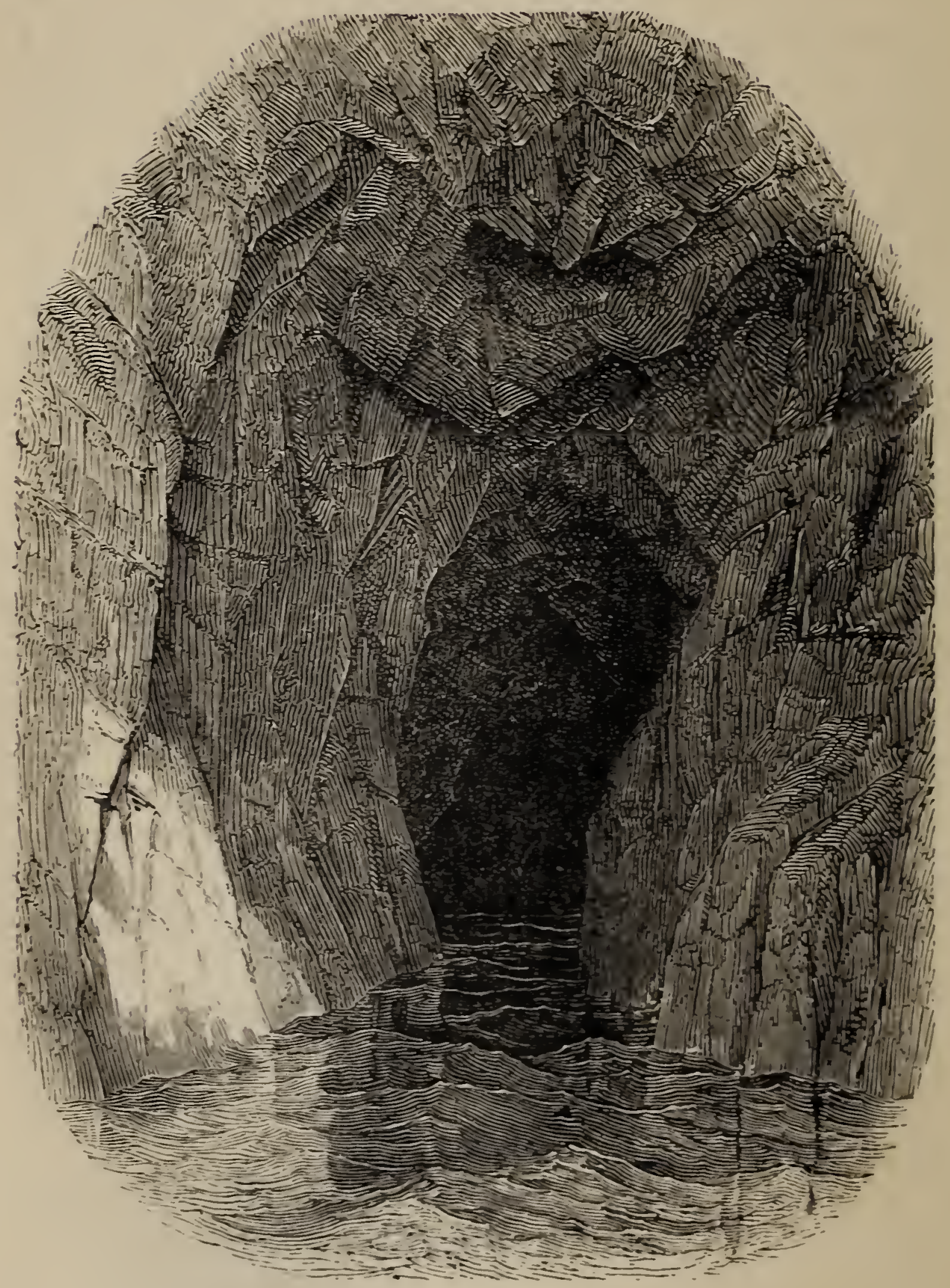

DOLOR HUGO. 


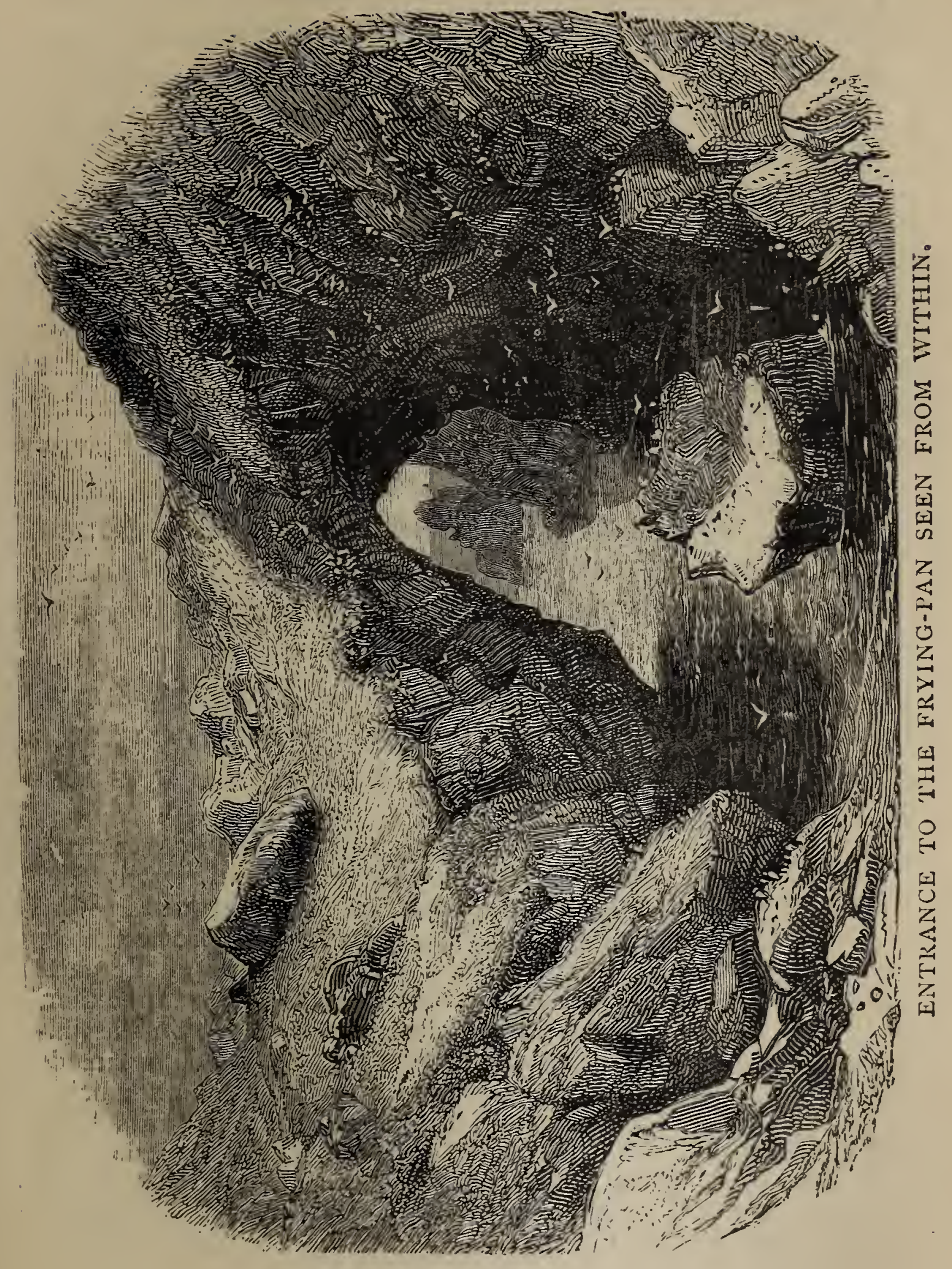


circumference of a circular bed of shingle and pebbles rises a shelving funnel-shaped cliff, naked below, but clothed above with a luxuriant vegetation. Its depth is two hundred feet, and the area of the rim of the cavity nearly two acres; the diameter of the beach at the bottom being at its widest part 126 feet. Seen either from above or below, it is a most remarkable object. The predominant hue of the shelving rocks near the base is bluish pink, and here may be collected very fine specimens of asbestos. ${ }^{1}$ The vegetation above comprises, among other plants, the sea-radish ${ }^{2}$ and yellow vetch; ${ }^{3}$ and about twothirds of the way up there is a portion of a hedge, which at some distant period slipped down bodily from above, bearing some tolerably fine specimens of tamarisk, a tree which flourishes on the adjoining estate.

This cavity is well known in the neighbourhood by the name of the Frying-pan, though its existence is scarcely known to tourists. Its for-

1 Asbestos : this mineral is distinguished by its fibrous structure; in some of the varieties the fibres are so delicately fine, and so flexible, as to resemble flax or silk; hence they were woven by the ancients into cloth, which, being incombustible, was sometimes made use of to enfold the bodies of the dead before they were placed on the funeral pile, and preserve their ashes. In the manufacture of this mineral into cloth, the filaments were mixed with those of flax, and formed into threads and woven. The cloth was rendered pure by fire, the flax being burned out. The name is of Greek origin, and signifies "incombustible." A fourth part of its substance is magnesia. In modern times it has been made into paper, but being rigid and fragile, the only superiority which it has over common paper is, that when thrown into the fire any writing on it disappears. In Russia gloves are still said to be made of it.

${ }^{2}$ Ráphamus maritimus.

3 Vicia lutea. 
mation may, I conceive, be well accounted for by reference to what has been remarked respecting the Lions' Den in a previous chapter. The archway represented in the cut was formerly the mouth of a cave, having, before that, been the extremity of a lode of soft rock, which in process of time crumbling away, gave admission to the sea and formed a cavern. The roof of the cavern, with the exception of the part just above the entrance, was composed of a soft, loose stone, and being unable to bear up the superincumbent weight, fell in, bringing with it the soil which it supported. The fallen mass at first perhaps filled up the mouth of the cave, but for no long period. The flowing and ebbing tide by degrees washed out the loose soil, and hastened the work of decomposition. In this stage of its existence it resembled what the Lions' Den was within the memory of living men, a deep hole with perpendicular walls. Every spring shower washed down a portion of soil which the preceding winter's frost had loosened; the detritus was forthwith washed away, and made room for a fresh accumulation; and this process was incessantly being repeatec, until the sides of the cavity exchanged the perpendicular for a sloping character, the base during the whole period having scarcely altered its dimensions. Geological speculations rest not unfrequently on a very unsubstantial foundation; but if this be not correct, I can form no other conjecture. It does not often happen, that even the most experienced geologists have the opportunity of referring to such evidence for the confirmation of their theories as is afforded 
by Lions' Den, caught, as it was, in the very act of formation, and watched during at least two steps of its progress.

The romantic fishing-village of Cadgwith is situated at the termination of an exceedingly pretty valley, which runs down from Ruan-minor "Church-town," and is sheltered on either side by steep hills. The descent on the south passes very near the edge of the Frying-pan, which nevertheless is so hidden by hedges of tamarisk that it requires to be searched for, as it cannot be seen from the road. Cadgwith belongs partly to the parish above named, and partly to Grade. Grade Church $^{1}$ is about half-way between Landewednack and Ruan-minor. Ruanmajor is more inland, and further to the north, being easily distinguished by its being surrounded by trees.

These four parishes were anciently included in one, and called Saint Rumon. This saint and bishop of Cornwall, who probably lived in the ninth or tenth century, appears to have been one of the many saints who came over from Ireland into Cornwall, in order to court, in our valleys and upon our shores, that heavenly contemplation to which they had solemnly devoted their lives, and from which they were apprehensive of being drawn away by the solicitations of their friends near them. St. Rumon chose his retreat in the Nemæan Wood in Cornwall, which was formerly very full of wild beasts, and there made

I The body of this church has been recently rebuilt, and decorated internally with great taste, through the exertions of the Rector, the Rev. F. C. Jaclison. 
himself an oratory. The precise situation of the Nemæan Wood is not given by his biographer, but being stated to be near Falmouth, it is supposed, by Whitaker, to have occupied the peninsulated ground which terminates in the Lizard. Near the church of St. Grade is an estate which is known from tradition to have been the particular residence of Saint Rumon, and is therefore denominated St. Ruan at present; both the Ruans, Major and Minor, are also, in the "Valor of Pope Nicholas," denominated expressly " the Church of St. Rumon." Here then, though all traces of the name have now vanished, was the Nemæan Wood of Cornwall, spreading all over the broad back of the peninsula, ${ }^{1}$ defying by its combined powers all the blasts that now sweep this region with so much violence, and affording warm shelter for beast or man in the interior of it. Here, therefore, was the oratory of St. Rumon,

1 The present desolate condition of Goonhilly Downs must not be considered conclusive evidence that they were at no time covered with wood nor frequented by wild animals. In other parts of the country, now equally unproductive of trees, appearances have been discovered indicative of a period when forest scenery was not unknown. In the year I 740, many large pieces of unknown timber were dug up near Hayle, in such a position that they must have grown near the place where they were discovered. A few years later, an oak tree, furnished with branches and leaves, was found at the depth of thirty feet beneath the surface in the parish of Sennen. Near the same spot were discovered many horns, teeth, \&c., of large deer. Yarts of the strand between Penzance and St. Michael's Mount present indications of a forest of oak, willow, and hazel, the stumps of which, firmly rooted in the soil, were only a few years since distinctly visible at low water; the ancient name of St. Michael's Mount was "Carick luze in Coos," or " the hoar rock in the wood." 
within the thickets of the Nemæan Wood. The thickets, however, had been cleared of the wild beasts when the biographer (Leland) wrote the life of the saint, and the site at present only partially retains any of its original wildness. This part is Leland's "wyld moore, cawled Gunhilly, i. e. Hilly Hethe ; wher ys brood of catyle." This is a tract of land near three miles across, chiefly consisting of a loamy soil, but bearing not even copse-wood at present; on which those little horses of Cornwall used formerly to be bred, the memory of whom is still preserved in the remembered appellation of Gunhillees, and close to which the church of St. Grade has a portion of its parish now. "There is a kinde of nagge," says Norden," bred upon a mountanous and spatious peece of grounde, called Goon-hillye, lyinge betweene the sea coaste and Helston; which are the hardeste naggs and beste of travaile for their bones within this kingdome, resembling in body for quantitie, and in goodnes of mettle, the Galloway naggs. ${ }^{1 "}$

"Here, near to the site of St. Grade's Church, at the village still denominated 'St. Ruan' from the fact, did St. Rumon live, having a cell for his habitation, and a chapel for his devotions, regardiess of the wild beasts around him, seeing them perhaps in his walks, hearing them perhaps in his prayers, yet beholding them probably to flee the face of this strange intruder on their

1 "A strong, punch, and spirited horse is, with us, generally" called a Goonhilly, from a wild downs of that name (stretching almost from Helston to the Lizherd Point), anciently famous for such little horses."-Borlase. 
privacies. About a quarter of a mile to the north-east of Grade Church is a noted well, from which is fetched all the water used in baptism at the church. ${ }^{1}$ It is walled up at the back and sides with dense black iron-stones (serpentine); but the front, and particularly the arched entrance, is composed of coarse granite. The

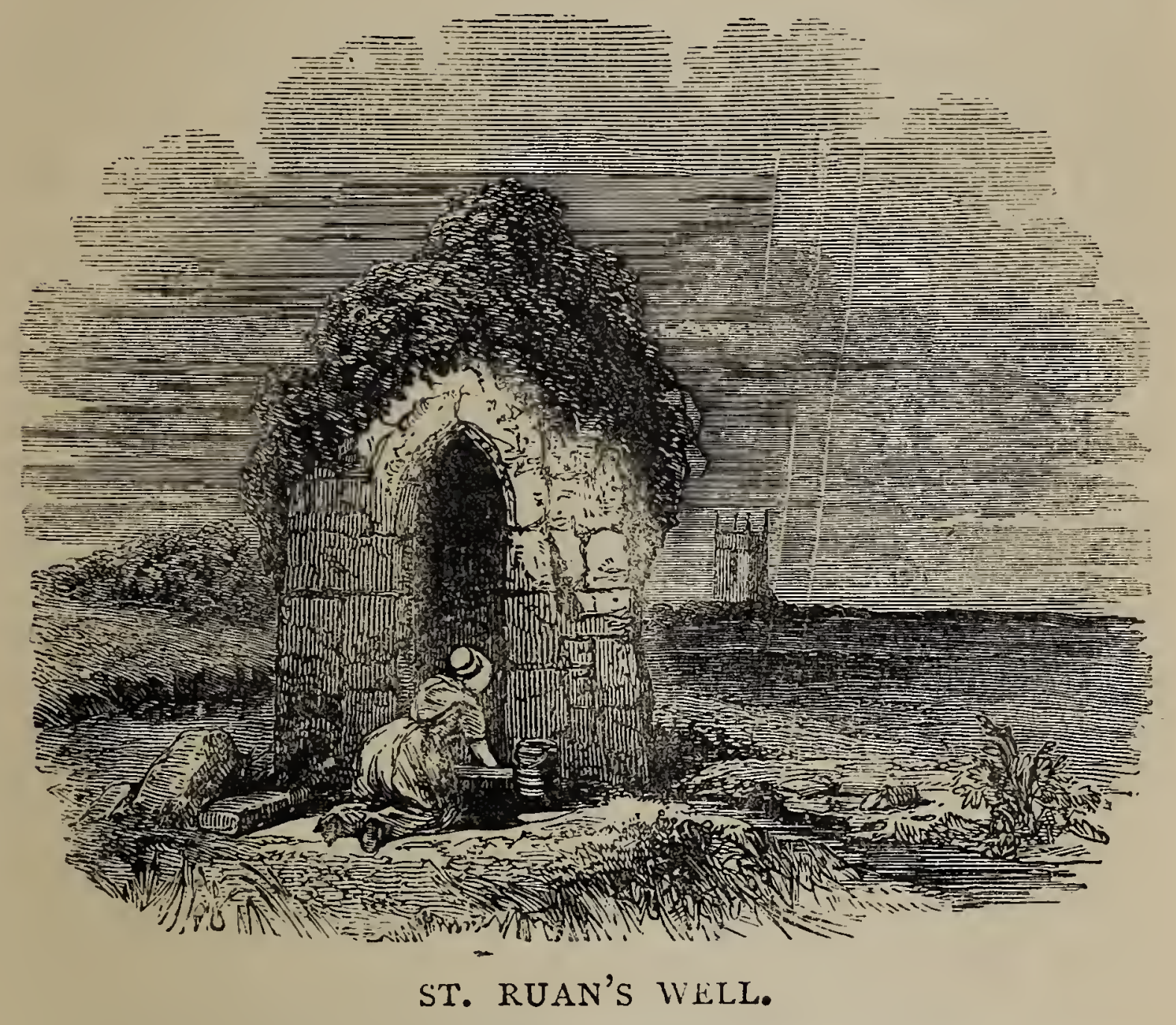

water, which is always up to the brim of the basin, is very fine and pellucid, and remarkably cold in summer. Hence St. Rumon must have been taken in order to be made a bishop; but he soon probably returned from his palace at St. German's,

1 The visitor must not be induced to imagine that St. Ruan's Well, in its present " restored " condition, bears any resemblance to the venerable and picturesque structure figured above, 
and resettled in his hermitage at St. Ruan. He certainly died at his cell, and was buried in his oratory, and then was made a saint by the reverence of the country adjoining. His oratory thus expanded into a church at some distance, his wood was formed into a parish, and the wild beasts were dislodged to make room for human habitations. Yet his relics were preserved with religious attention at his own hermitage-chapel, and his name was fixed with religious veneration to it. The place took the name of St. Ruan, as the parish church took the equal appellation of Ruan. But when Ordulph, Duke of Cornwall and Devonshire, under the Saxon sovereigns, in 96I, erected a monastery at Tavistock, he was so struck with their reverence for Rumon's name, Rumon's relics, and Rumon's memory, that he took up the bones of the saint and transferred them to his new monastery. There the saint was buried in pomp, with the ensigns of his episcopal dignity upon his monument, and with the tradition of his saintship attached to it. There, as William of Worcester additionally informs us, 'Saint Ramon, a bishop, an Irishman, lies in a shrine within the abbey church of Tavystoke, between the quire and St. Mary's Chapel.' And there also his life was written, from such memorials as then remained of him at St. Ruan, after a lapse of years so great that his biographer says his wood was formerly very full of wild beasts, and thus uses a language which throws us back two or three hundred years in time, even nearly to the commencement of our Cornish see. Thus should Rumon come in, one of the very first bishops of 
Cornwall, and long prior to any of the Saxon prelates." 1

In Ruan-major is the old manor-house of Erisey, formerly the property of a family of the same name now extinct. "One of these Eriseys, dancing with other gentlemen and ladies at Whitehall before King James I., through the violent motion and action of his body in the middle of the dance, had his cap slip from his head and fall to the ground; but he instantly with his foot tossed it on his head again, and proceeded without let or hindrance with his part in that dance, to the admiration of all who saw it, which gave occasion to King James to inquire who that active gentleman was, and being told that his name was Erisey, he forthwith replied ' I like the gentleman very well, but not his name of Heresy!'”

Little interest attaches to any of these churches, except Landewednack and Grade, beyond that which a country church ordinarily claims; therefore, as the inland country is for the most part flat and unvaried, we may return at once to the coast.

Cadgwith is a convenient resting-place for tourists fond of sea expeditions. It boasts of a comfortable hotel. The population is composed principally of fishermen, to whom may be added the greater part of the preventive-men belonging to the station. Many of these last spend a. considerable part of their leisure-time in polishing specimens of serpentine, and as in the dis-

'Whitaker's "Ancient Cathedral of Cornwall," chap. vi. §vi. 
charge of their duty they are obliged to perambulate the whole of the coast, they frequently fall in with the rarer and more beautiful varieties.

One is not likely to meet with much incident here worthy of being recorded, or to gain much information, except on subjects connected with the fisheries. An incident of the latter class, indeed, occurred some years since, which will well bear repetition. A man was fishing at anchor, and hooked a very large conger, which with some little difficulty he hauled into the boat. No sooner did the huge monster find himself fairly out of his element, than he seized the astonished fisherman by the throat with his sharp teeth, and wound himself, boa-constrictor-fashion, round his body. Fortunately the man did not lose his presence of mind; so, seizing his knife, he stuck it into the creature's spine just below the head, when it relaxed its hold and fell dead. We read sometimes of formidable conflicts between men and fish, when the latter have the advantage of being in their native element; but such encounters in the air are very uncommon. We cannot suppose in this instance that the fish was taught by any instinct to seize the throat of the man, but merely that it flung itself about in its struggles to escape, and fastened itself on the first object that it encountered.

About the same time, a boat returning from a night's fishing, fell in with a large sun-fish, which lay basking on the surface of the water, and the crew secured it with a boat-hook. Being too large to be lifted in, it was taken in tow, brought to shore, and cut up as bait for the crab-pots. It. 
weighed several hundred weight. After all the trouble, however, that was expended upon it, it proved to be of little value. The flesh resembled the fat of bacon in appearance, but was so hard that it required a very sharp knife to make any impression on it. Consequently the crabbers, finding it impossible to pierce it with the pointed

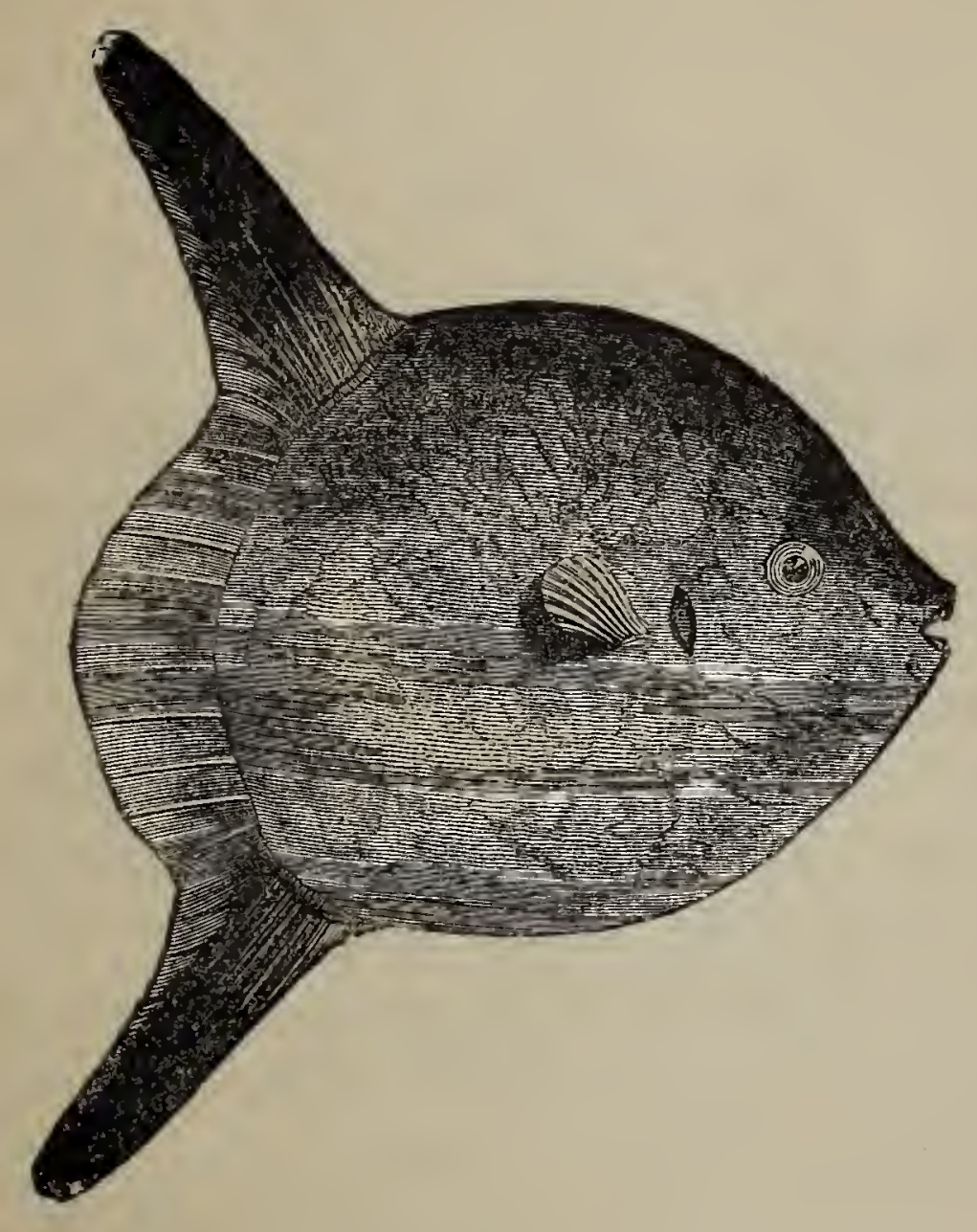

THE SUN-FISH.

sticks with which they fasten the bait to the pots, threw it away. All that I saw of the fish was a piece I found floating off the Lizard, which had been thrown over by the fishermen. I fancied at first that my prize was a piece of bacon, fallen overboard from some vessel; but the very rough shagreen-like skin soon told its history. 
North of Cadgwith a wide and very good pathway runs to some distance round the verge of the cliff, and brings us to Ynys Head. Here again the rocks are very grand. Several rare plants grow here, and among them asparagus in great profusion. In the month of July the foliage of this plant turns a brilliant golden yellow, and with its numerous scarlet berries gives a marked feature to the shelving cliffs. So abundant is it, and so luxuriantly does it grow, that it is often collected for the table; it is said to be much more bitter in its wild state than when cultivated.

On the hill beyond Ynys Head, and near the signal-station, are the remains of a stone structure resembling "the Apron" mentioned above. Beneath the signal-station occurs a mass of fine red serpentine, and here is a cave which is said to communicate with the old manor-house of Erisey, a mile or two inland. The rocks in this neighbourhood are still frequented by the chough, ${ }^{1}$ or red-legged crow (see next page), a pair of which may often be seen soaring about the inaccessible cliffs.

Caerleon Cove, yet further to the north, is the termination of a romantic valley called Poltesco, which is well worthy of being explored. It differs in character from every other valley on the coast, and being composed of massive rocks, through which a tolerably large stream battles its way, resembles a mountain ravine, rather than

${ }^{1}$ Here pronounced "chaw," in imitation no doult of the note of the bird. 
a seaside outlet. A painter coming hither to practise his art, should he grow weary of the sea, will here find some very pleasing combinations of rock and water, interspersed with picturesque cottages.

Kennack Cove is remarkable as containing the greatest extent of sandy shore in the district.

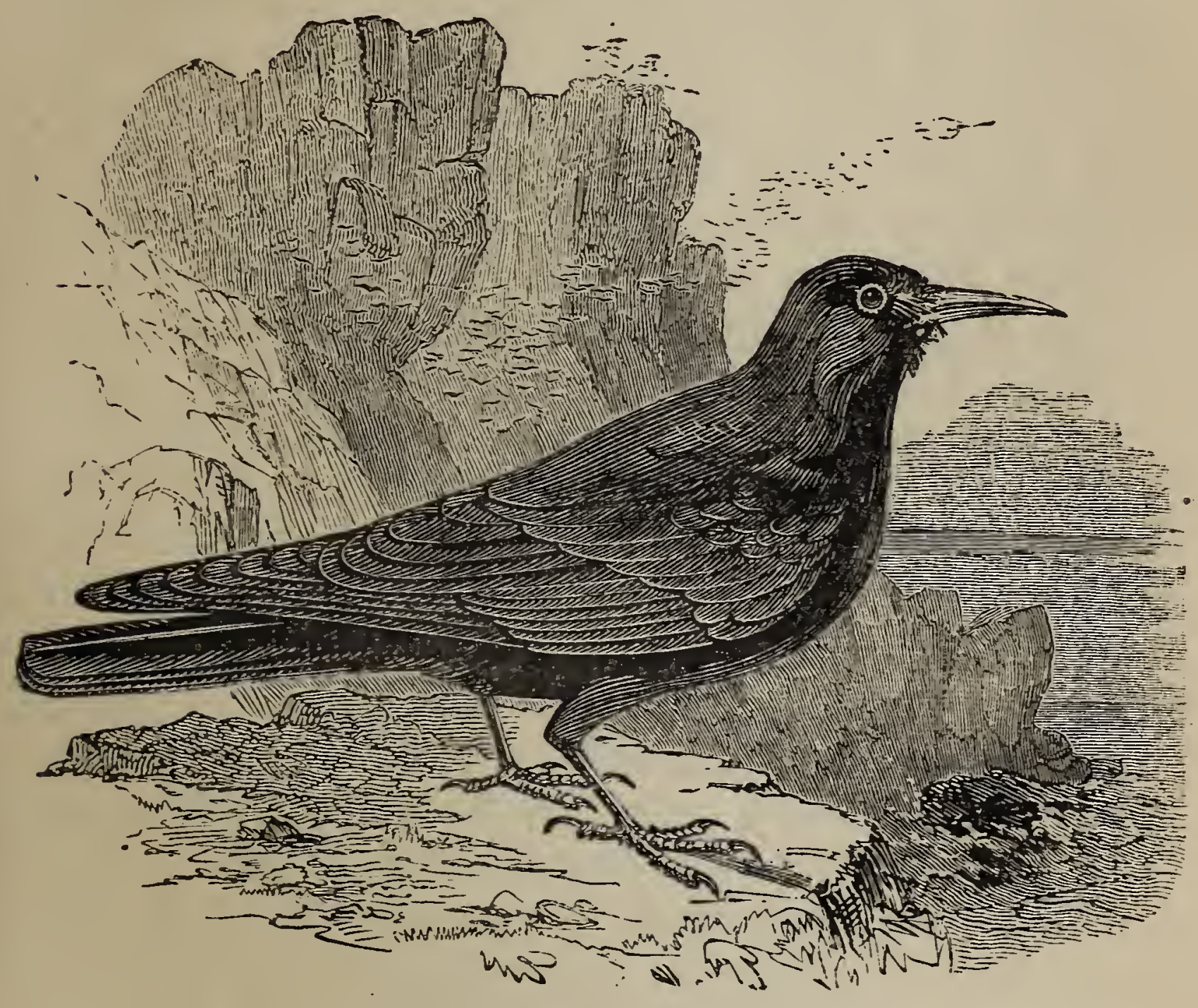

THE CORNISH CHOUGH.

It is divided into two little bays by a ridge of rocks, which run out to a great distance. The land is low, and is composed of a succession of sand-hills covered with numerous curious, and among them several rare plants. During the months of summer and autumn it is selected as. a most favourable spot for hauling the ground-- 
seine, for which the shallowness of the water admirably adapts it. I had the good fortune to be present on one occasion when, except that the season was not sufficiently advanced for the fish to have come near the shore in large quantities, all circumstances were favourable for this most interesting undertaking. The day had been sultry and cloudless; the wind was from the west (at least so said the fishermen, I could detect none at all), the sea calm, except when it played round an opposing rock or curled in narrow white lines along the shore; the sun had gone down an hour; the moon was up and at the full, and it was dead low-water and springtide. The boat which carried the net landed myself and the other spectators on the backs of the fishermen who were to act on shore, and who, having politely deposited us on the hard sand, returned for the end of the rope which was attached to the net. The net itself was, as well as I can recollect, upwards of a hundred fathoms long, and three fathoms deep, having a series of corks and leads attached to either edge. The boat then put out to sea until it had reached what was considered the proper distance from land, when the men commenced throwing over the net, simultaneously rowing with all their might across the mouth of the bay. When the net was fairly overboard, they directed their course with all speed towards land, carrying with them a rope attached to the other extremity of the net. This being landed, all hands proceeded to drag the net ashore, gradually bringing the two ropes nearer, until they had 
arrived at the net itself. All this while, the net, which had assumed a semicircular figure, had been sweeping the bottom with its lower edge, the upper part being buoyed up to the surface by the corks, so that whatever fish had been swimming about in the enclosed space had their retreat effectually cut off. The net was now gathered in on the sand and its contents placed in the boat, and preparations were made for another haul.

The scene, it may be well supposed, was sufficiently striking in itself: but the excitement was greatly heightened, as it grew late, by the appearance of a large body of men, women, and boys, furnished with launce-hooks and baskets, busily employed in fishing for launces. ${ }^{1}$ I was soon attracted by a little group who had gathered round a man belonging to this party, and found that he had raked up and seized hold of a small fish which he supposed to be a launce, but which was what he called a sting-fish. It had wounded him in the thumb, and so seriously, that he declared he was suffering intense pain all the way up to his shoulder, so that he had not the power of moving his arm. I observed afterwards that the seine fishers were very cautious not to touch any of the fish in the net until they had ascertained that it was not of the same kind. I could not get a sight of a specimen, but conclude that it was the Lesser Weever, ${ }^{2}$ a fish described by Yarrel as being "about five inches in length; active and subtle in its habits, burying itself in 
the loose soil at the bottom of the water, the head only being exposed. It thus waits for its prey-aquatic insects or minute crustaceous animals - which the ascending position of its mouth enables it to seize with certainty. If trod upon, or only touched, while thus on the watch, it strikes with force either upwards or sideways." In what consists the venomous character of the wounds which it inflicts is not known, but there can be no doubt that its sting is formidable, and exceedingly rapid in its effects.

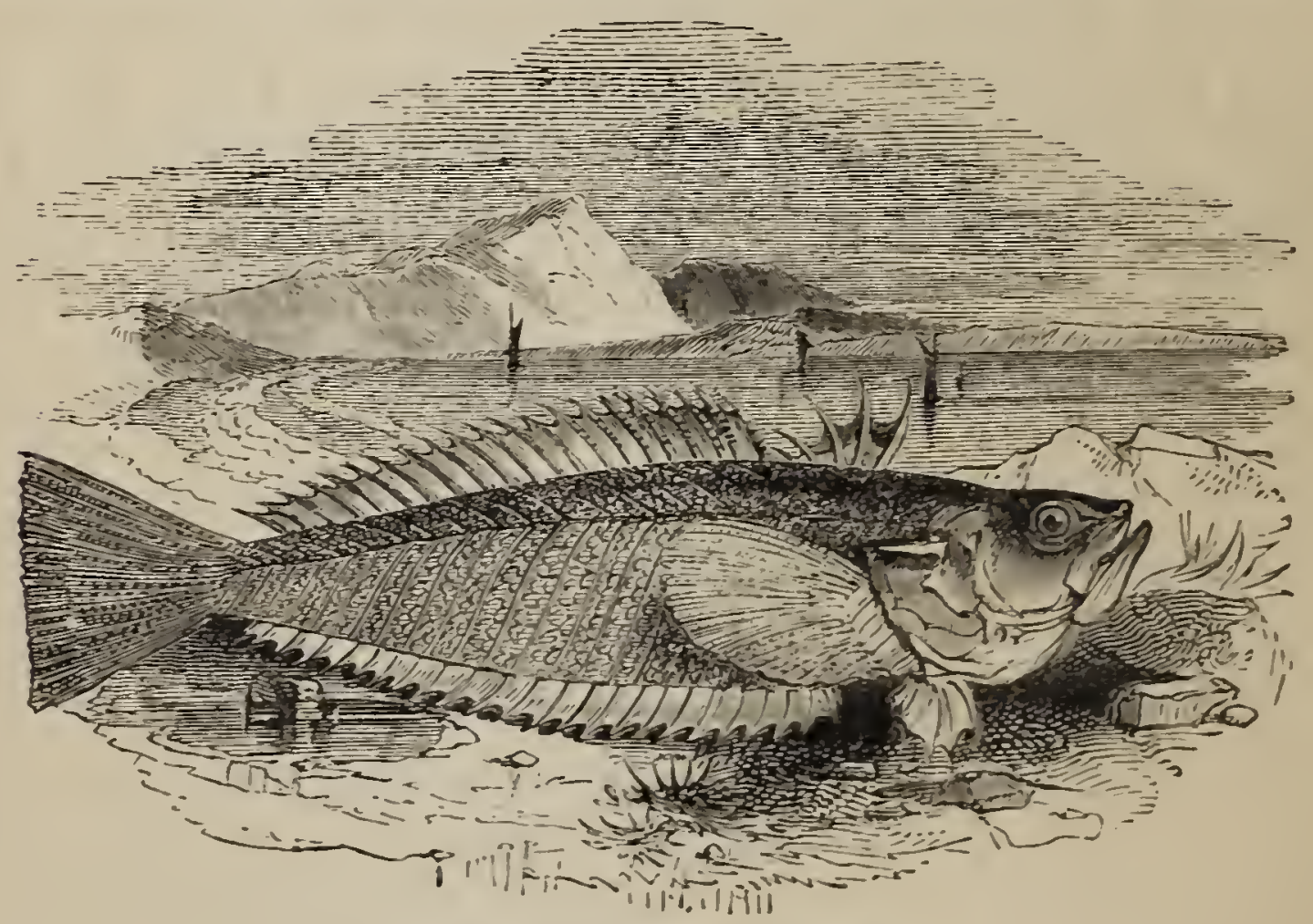

THE LESSER WEEYER.

The fish usually caught here in the groundseine are turbot, soles, and other flat-fish, grey and red mullet, basse, \&c. Of all these the red mullet is most highly prized for its fine flavour. The liver particularly is thought a great delicacy. It ought to be eaten very fresh, as the part which is most in request very soon dissolves, and is consequently lost. Ancient epicures were as 
sensible of the merits of this fish as the moderns. In the corrupt days of the Roman Empire "a mullet of six pounds weight is recorded to have produced a sum equal to $£ 48$; one still larger, $£ 64$; and even $£ 240$ were given for three of a very unusual size, procured on the same day, for a repast of more than usual magnificence." The red mullet caught on this coast are eagerly bought up for the London market.

Not unfrequently, in autumn, the labours of the seiners at Kennack are rewarded by a catch of mackerel, a fish invaluable to the poor both for present consumption and when salted, for winter use. The mackerel was formerly thought to be a migratory fish, coming to us in spring from some unknown sea, and leaving us again before winter; fishermen, however, and I believe most naturalists, are now of opinion that at the approach of winter mackerel simply retire to deep water, and remain there until the return of spring. If caught at all early in the year they were not prized, being formerly thought unwholesome until after the history of Balaam and Balak had been read in the churches. But now the winter fishery is the most profitable. Soon after the close of the herring fishery, in which many of the Cornish boats engage in the Irish Sea, they proceed eastward, and fish with driftnets for mackerel in the deep parts of the Channel off the coast, from Plymouth to Brighton, and supply the London markets, or sell the produce of their labours to French fishermen, who find it more profitable to purchase of the English than to catch for themselves. As the season 
advances they come into shallower water, and are caught in great numbers both with driftnets and seines. In autumn the shoals disperse, or, to use a provincial expression, "the schulls break up," and it is not until this has taken place that they are caught in any quantities with the hook. They are then very voracious, biting eagerly at any glittering or bright-coloured substance which is made to move quickly through the water. A bit of red and white leather, a piece of tobacco-pipe, a gaudy fly; any of these makes a tempting bait; but that which the Cornish fishermen prefer is what they call "a last," that is, a long and narrow piece of shining skin, cut from the tail of one of the mackerel or from that of the gurnard.

The bait being drawn swiftly through the water, the hook does not descend to a great depth, nor is a large quantity of line necessary; this facilitates the hauling in of the line; and if the fish be abundant, two men will take six or seven hundred in a day, and sometimes even more. This method of fishing is usually called whiffing. The sport is sometimes interfered with by a long, eel-shaped fish, the gur-fish, or longnose, which not knowing that the bait is intended for a worthier object, swallows it, hook and all, and it cannot be extricated without great trouble. It is greatly disliked by the fishermen, on account of its untimely interference with their occupation; and because its bones are, when boiled, of a bright grass-green hue, they refuse to eat it.

Kennack Cove is bounded on the north by a 
long precipitous headland, appropriately called the Blackhead. From various parts of this promontory are brought some of the most beautiful specimens of serpentine. One vein in particular, the position of which is kept secret (it is said to be exhausted), consists of pure white steatite, intermingled with fragments of green, red, and black serpentine, containing spangles of diallage. The vein itself is not more than two inches in thickness, but is well adapted for letter-weights and brooches, for which purposes few opaque stones can compete with it in beauty.

It would be well worth our while to continue our survey for many miles in this direction, but as our time is limited to a week, and as this part of the coast does not strictly belong to the Lizard district, we must return to our headquarters, prepared to sally forth on the morrow on a ramble round the coast between the Soaprock and Helston. 


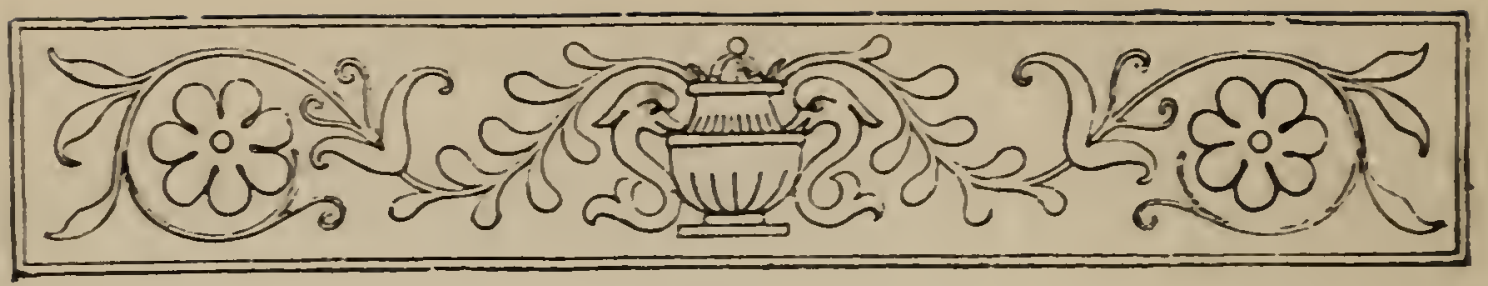

\section{CHAPTER V.}

Pradanack Head-Gull-rock-Mullion Island-Mullion CoveCopper-mine - Mullion Church - Smuggling - PolurrianShipwrecks-Gunwalloe Cove and Church-Dollar-mineHalzaphron Cliffs-Loe Pool-Penrose-Helston-MaineAmber Rock-Furry-day.

LEAving the Soap-Rock, and continuing our course northwards by Vellan Point, we arrive at Pradanack Head, the rocks in the neighbourhood of which are remarkably grand, assuming the character of those observed at Pen Olver ${ }^{1}$ and the Bass Points, but much loftier. Here we may in several places descend without difficulty, by the sloping turf, to within the distance of a few yards from the water's edge, ind if the weather be sunny and the time afternoon, watch the white waves sweeping into the gullies beneath, and displaying, as the spray is dashed back, the prismatic tints of the rainbow. The same phenomenon may of course be observed whenever 


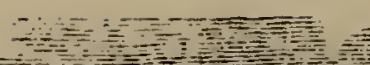

$+4$

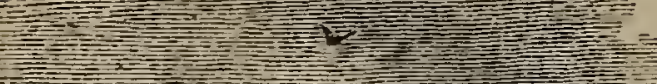

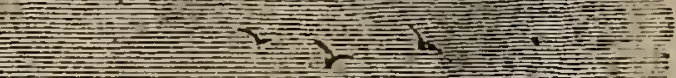

.

, (a)
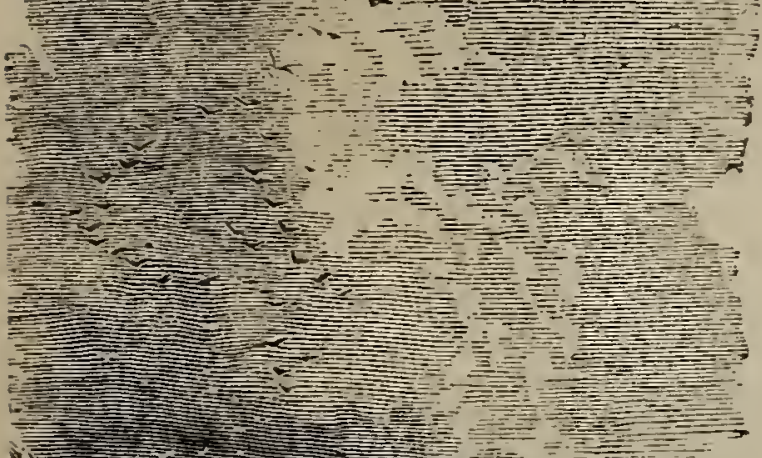

the rays of the sun shine on falling drops of water, provided that the spectator be standing at the right angle; but this is a difficult position to attain, except where the coast is much broken by rocks, and the descent practicable to the water's edge.

Passing on, still towards the north, a sudden turn

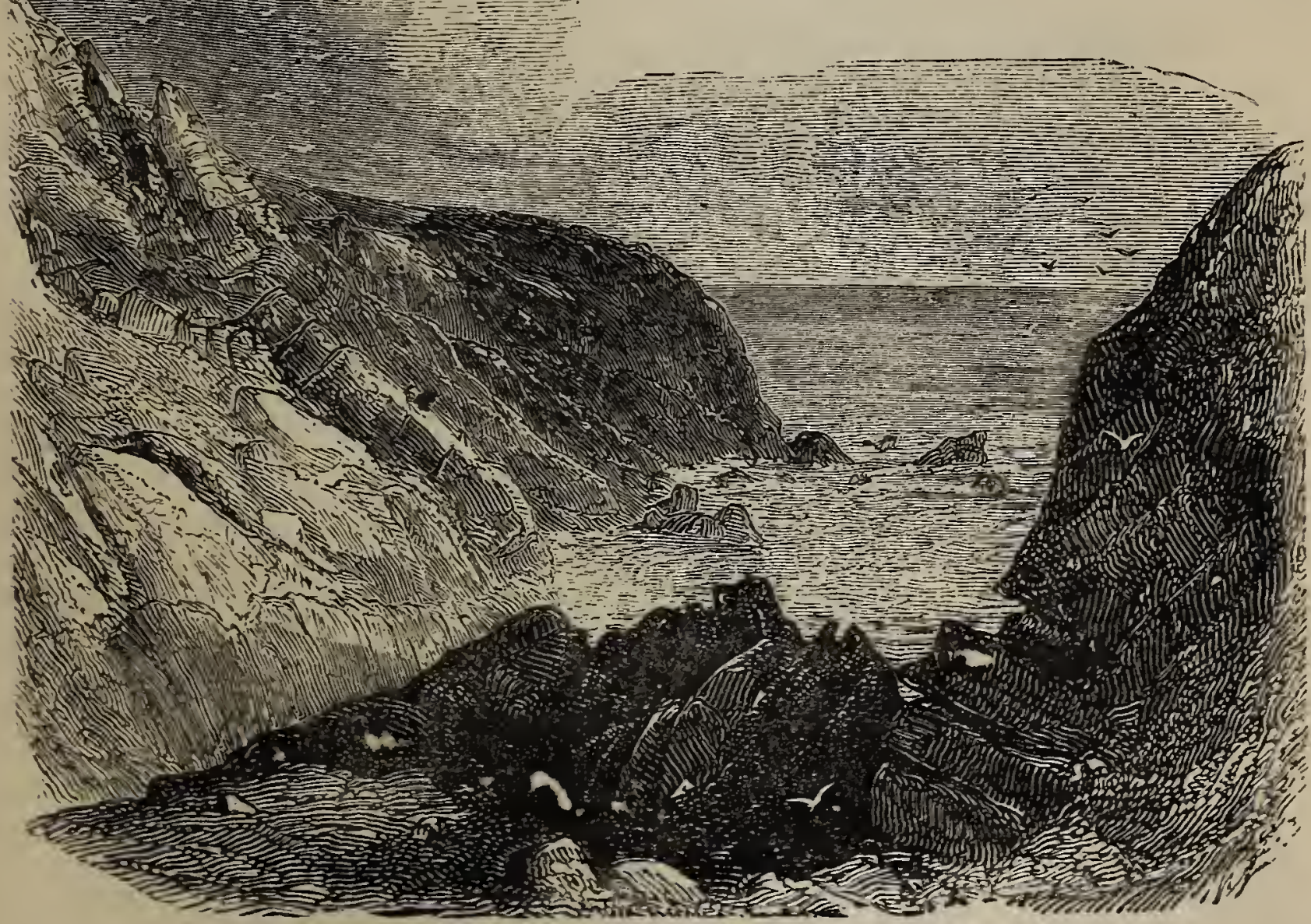

PRADANACK HEAD.

brings us in full view of the sweeping line of coast which forms Mount's Bay. In the extreme distance the high ground, which runs out and terminates in the Land's End, appears as if 
suspended between sea and air. The town of Penzance may be discovered at the very extremity of the bay, in front of which St. Michael's Mount rises, a castellated pyramid just opening behind Cudden Point, the headland nearest to it.

The next object of interest which catches the eye is Trewavas Head, a pile of granite rocks, among which may be distinguished the chimneys of a forsaken mine, which until recently was

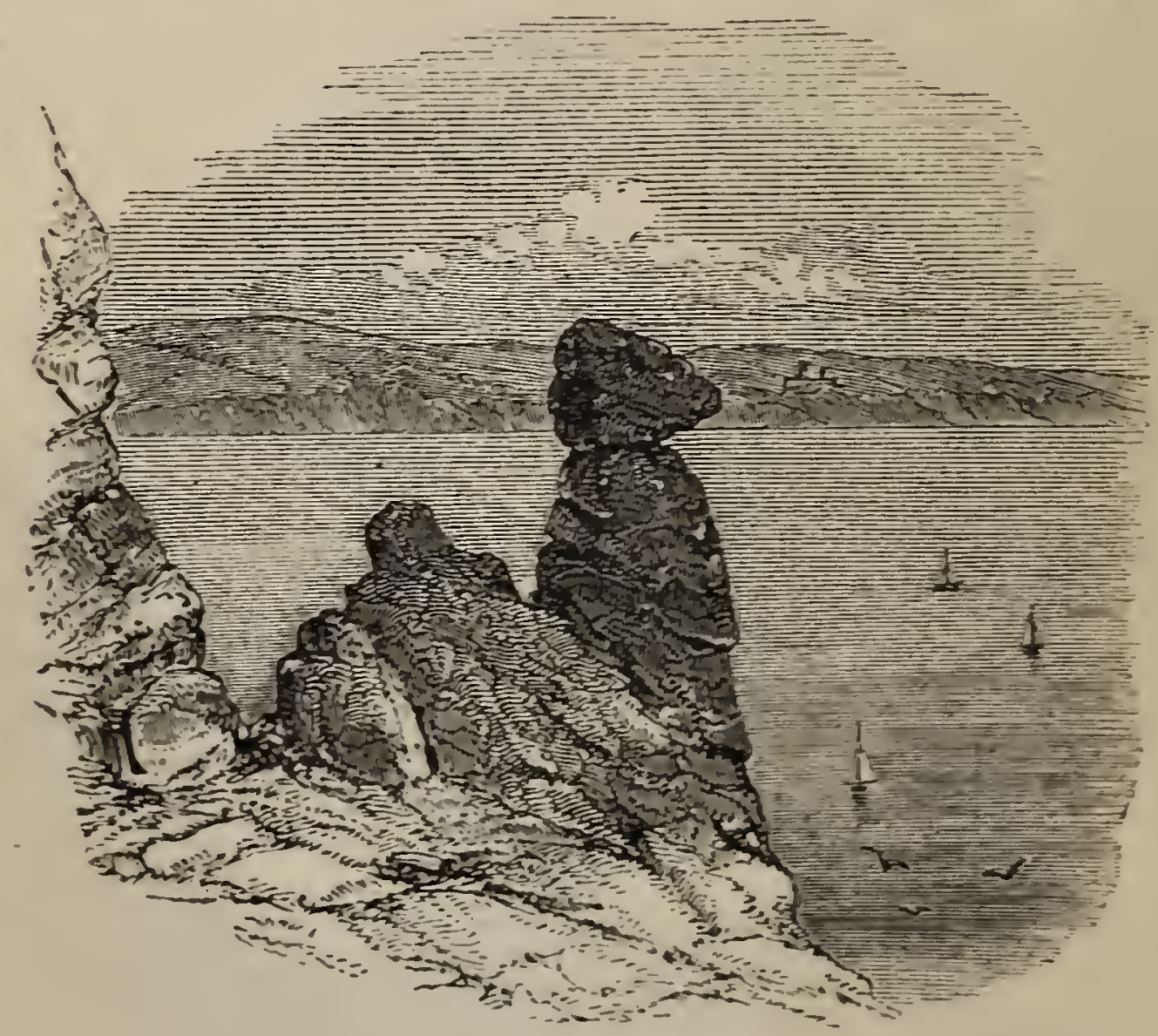

BISHOP-ROCK.

worked under the sea. A steady gaze by one who knows what to search for will detect among this group a single columnar rock, which, seen from a certain point, bears a striking resemblance to the human figure. The body, which is in a half-kneeling posture, leans against a table of stone, not unlike a reading-desk, for which reason, and because the head is furnished with an 
appendage which bears no unfanciful resemblance to a wig, it is known by the name of the "BishopRock." If seen at all from this distance, it is a mere pillar of stone.

Still running the eye along from more remote objects to nearer ones, it lights on Porthleven, a fishing-village furnished with a fine pier and a small but secure basin, which was constructed to be a harbour of refuge for embayed vessels in stormy weather. Within the last few years, Porthleven Harbour has been puichased by Messrs. Harvey, of Hayle, and much improved. A brisk trade has been the consequence.

Behind Porthleven rises Tregoning Hill, on the side of which stands Breage Church, interesting, since the publication of Evelyn's "Life of Mrs. Godolphin," as containing the remains of that inestimable lady. ${ }^{1}$ Godolphin House stands on the other side of the hill by which it is concealed. A long line of sand extends from Porthleven to a dark headland called Halzaphron, the central part constituting the Loe Bar, which will be described hereafter. Still nearer, Gunwalloe Cove is distinctly visible, with its church and churchyard, the walls of which are washed by the sea; and a. rapid glance brings the eye of the spectator along a picturesque line of cliffs and rocks to the objects which lie immediately at his feet.

1 The epitaph which is given at length in the Biography, is not now to be found; either it has been destroyed, or was inscribed on the coffin-plate. 
$\mathrm{He}$ is now standing on one of the eminences of a lofty precipice, and looks down on a craggy insulated rock, the summit of which is beyond the reach of the spray, except in very stormy weather, and is covered on its least exposed side by coarse grass, the other side being quite bare of vegetation. This is the Gull-rock, and well it deserves its name, for during
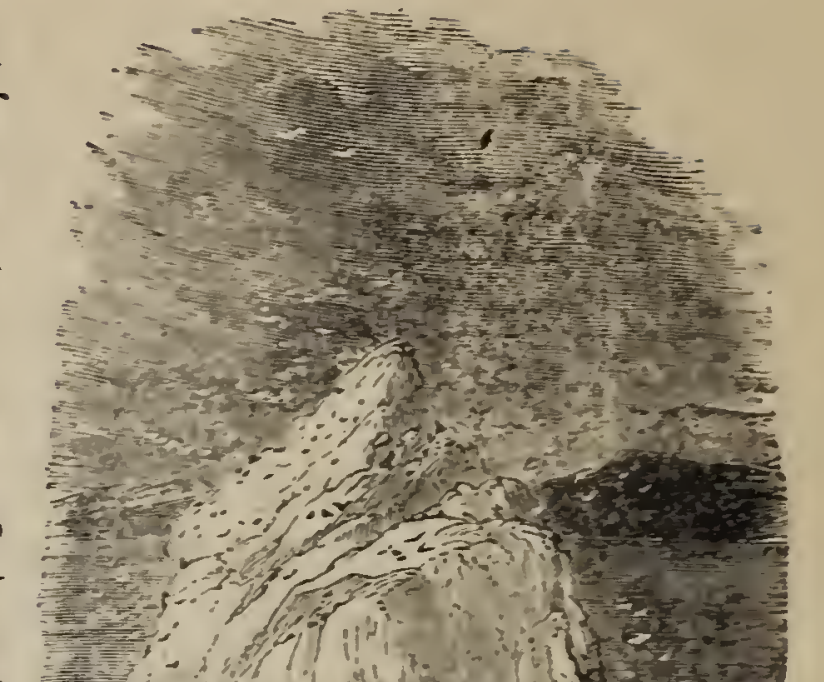

\section{䆜}


the same object, except that they and their progeny are more sedate and less noisy. Strange to say, though the extreme nests of each species are within a few feet of each other, the owners appear to hold no communication, nor in any way to mix with one another. Though tied by no treaties, and separated by no boundaries, either natural or artificial, each species retains its own habits, unmolesting and unmolested, and preserves a dignified indifference to its neighbours' doings, which some civilized nations of rational beings would do well to imitate. These neighbourly habits seem to have inspired them with supreme contempt of invasion by foreign enemies, for you may shout as loud as you please, or pelt them with stones until you are weary, without producing any sensation beyond what may be expressed by an increased clamour. At most, a few gulls will leave their perches and soar aloft over your head, uttering their note more distinctly, and almost giving to it a tone of defiance. On these occasions one of their cries is repeated several times at short intervals, and sounds more like a discordant laugh than the note of a bird. When the young are fully fledged, they swim about in happy parties round their stronghold, and soon after all disappear. In the autumn nothing remains to indicate where the colony was reared but the traces of their deserted nests.

About a quarter of a mile from the shore lies Mullion Island, a low rock, which, seen in certain points of view, bears something of the shape of a couching lion. Diminutive though it appears 


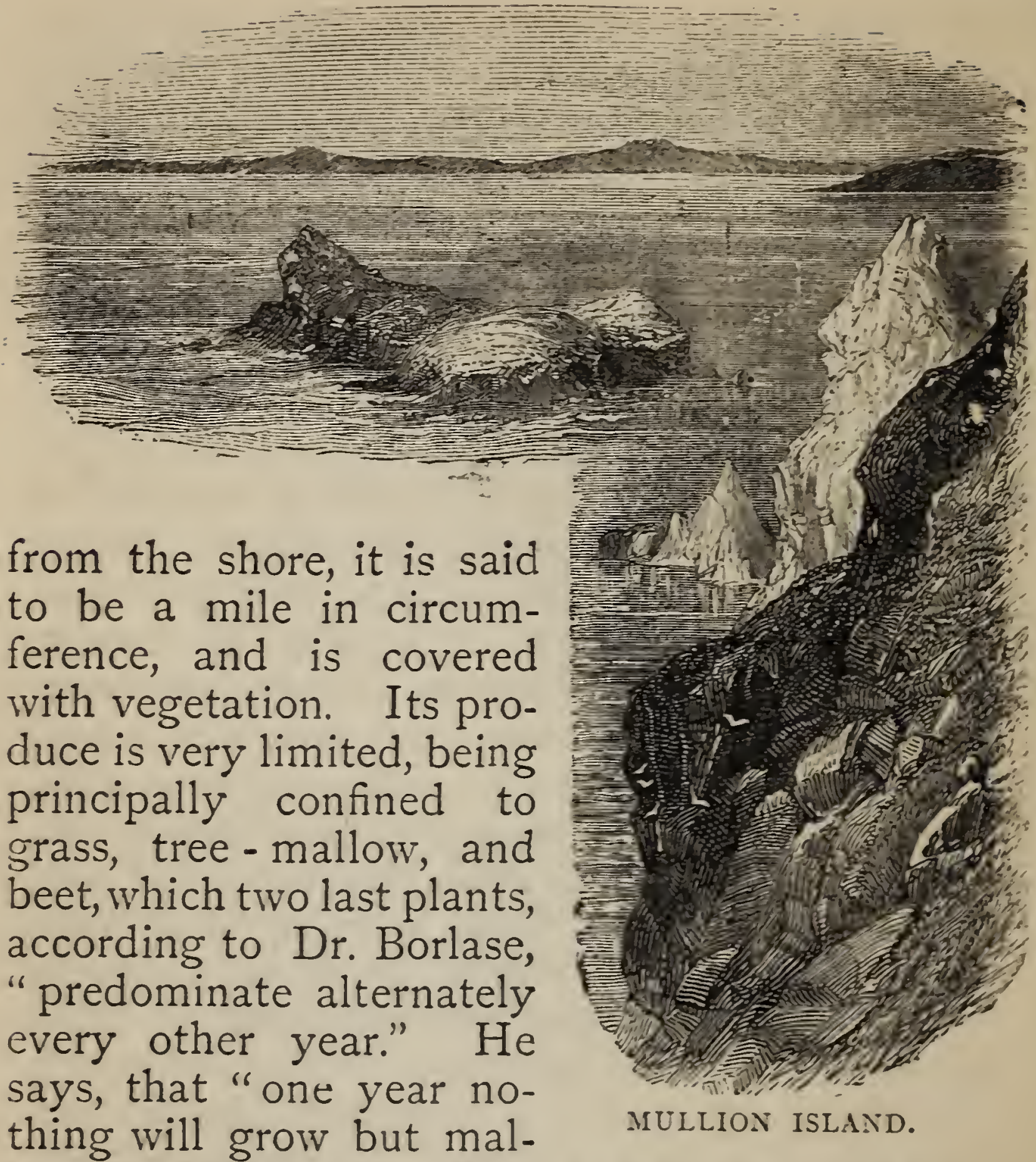
lows, and the next nothing but beets; so that in their respective turns they exclusively possess the island, and engross its scanty soil." I have had no opportunity of verifying this statement.

Mullion Island serves as a natural breakwater to Mullion Cove, into which we shortly descend by a steep declivity. If, as it has been conjectured with much plausibility, the names of places on this coast are of Phœnician origin, the name Mullion may well be derived from a word 
cognate with the Persian for "smooth;" for although it is too much to say that it is always a safe harbour, yet it often happens that the sea is in a very tempestuous state all around, except under the lee of the island; so that it is at least possible that some ancient mariner may have given the name to the only spot on the coast in which he could take refuge from a storm with any chance of security. The Pacific Ocean itself has no better title to its name.

Mullion Cove contains a mill (which is worked by a stream running down through the valley), some fish-cellars, and a few humble cottages, on which last, owing to the height of the risingground behind them, the sun, in the winter months, never shines. In one of these lives an old man who has been blind for many years, and who, though at all times contented and amiable, is glad indeed when the month of March is come, for he finds his solitary walk up and down the road in front of his cottage more cheerful when he feels the blessed sunshine falling on his sightless eyes.

Making our way to the beach between the seine-boats, hauled up beyond the reach of the surf, and in the fishing-season having all their stores on board ready for instant use, we find ourselves in one of the most romantic coves on the coast. Mullion Cove should be visited about midday on the second or third day after new or full moon. The tide is then low, and several interesting spots may be inspected which at other times are inaccessible. The rocks on both sides are very beautiful; that on the left is perforated 
by a natural archway many yards long, leading to an open part of the shore, which near the base of the cliff is covered with huge blocks of stone, and further out is composed of firm sand. No time should be lost in traversing this and rounding a projecting mass of serpentine, for on the other side of it lies the entrance to by far the most imposing of those caves on the coast which are accessible from the land. There can be no doubt that at some very distant period it was filled up by a lode of soft steatite, which has since been worn away by the action of the sea. It is now a huge chink between two sombre rocks, the entrance being partially blocked up by a smooth black pillar curved like the cutwater of a ship. It is a striking object when seen externally, yet the view from within is yet more so-impenetrable gloom above-brilliant light streaming in through the fissures, but revealing nothing behind-the smoothest of all possible sands-little pools of crystal water, so still that not even a sunbeam is seen to dance on them-richly dark rocks, so polished as to reflect the light with a splendour scarcely to be endured-the blue sea with its curled edging of snow - white lace - St. Michael's Mount, the fabled "tower in the sea," in the extreme distance; surely the poor blind man must, year by year, be endeavouring to recall his boyish memory of this scene, when the rays of the spring-tide sun for the first time light on his beaming face.

The first time that I explored this cavern was in company with a large party of holiday schoolboys, who can scarcely have forgotten how when 
we first discovered it, we regretted that we had not brought candles with us, and how one of the party volunteered to run to the village, a mile off, to procure some, and with what rapture he was descried with his bundle in his hand, and how eagerly every one crowded round for his share of the prize. But even the light of eighteen candles was insufficient to penetrate the gloom, or to give a distinct view of so much as the roof; though the ringing echo of the "three cheers for the boy that brought the candles" made up for the lack of adventure in the course of exploring. Another visit was in the November of I 844 , when the number of lights was reduced to two, hardly enough to save us from stumbling over the rocks. The floor was then strewed with apples sodden in water, which had been washed from a vessel that had recently been wrecked near the Land's End. As we approached the extremity of the cave we were compelled to retrace our steps as hastily as possible by the sudden rising of myriads of flies, which had probably taken up their winter quarters in. a spot inaccessible by the tide, but, disturbed by the sudden glare, swarmed around us and threatened to extinguish our candles and take refuge in our eyes and mouths.

My last visit was paid in August, 1873, in the company of three friends, two of whom were familiar with most of the picturesque scenery of Southern Europe. Though prepared by my description to see something exceedingly grand, they were lost in admiration, and urged on me the propriety of recommending all future tourists 
not to leave the neighbourhood without paying a visit to one of the most remarkable objects on the coast, the most picturesque cave in England. The cave on this occasion was illuminated by a faggot of furze, supplied by a fisherman who happened to be on the spot. It can be seen best two or three days after full or new moon, and in the early afternoon. Visitors who have their head-quarters at the Lizard will find at the "Church-town," distant about two miles, two inns, where they can obtain refreshments and comfortable lodgings.

The serpentine and diallage rocks are not generally productive of metals; it is only when they are traversed by lodes or veins of steatite that any mineral is found distinct from the usual constituents of the stone. About a mile inland from the mouth of this cave, and perhaps in a part of the same lode by the decomposition of which the cave itself was formed, a copper-mine was worked more than a hundred years ago. A piece of pure malleable copper was then found so large that it required the united efforts of four men to carry it. Other specimens of metal equally pure were found, but not in sufficient quantities to pay the expense of working. The mine then lay neglected for twenty years, when it was again worked for a short time. A fresh set of adventurers tried their fortune after the lapse of about thirty years; but though they discovered masses of valuable metal the speculation failed, and the works were discontinued. Recently, active operations have been recommenced, and the result has been the discovery of masses of rich ore, estimated at 
$£ 50$ a ton, and of malleable copper, worth $£ 90$ a ton. ${ }^{1}$ The metal wore the appearance of having been poured, in a melted state, into the crevices of the rock; it was, for the most part, flattened, and branched at the edges; it had the lustre of a new copper coin, and had here and there adhering to its side portions of steatite, stained of a beautiful grass-green.

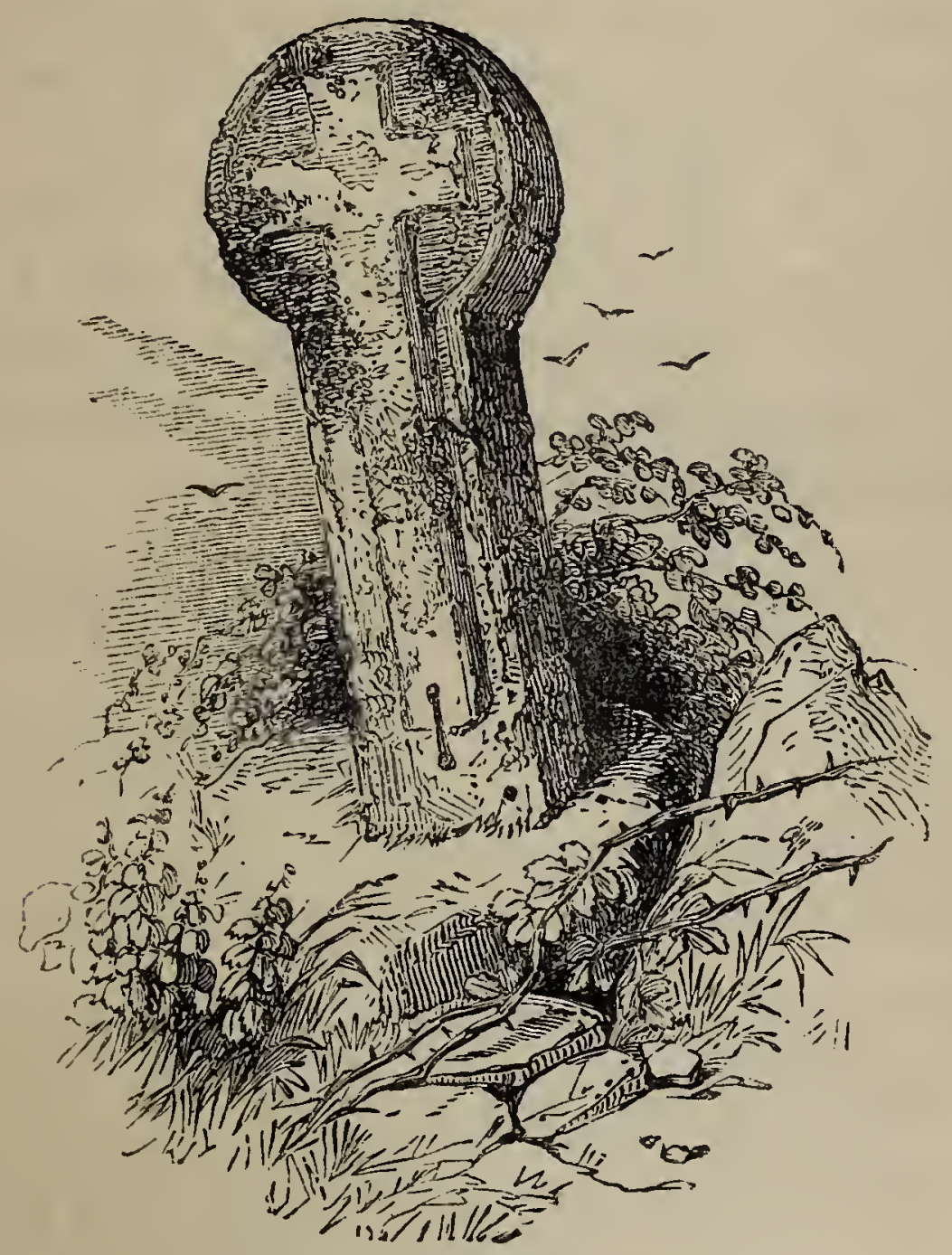

PRADANACIK CROSS.

In a field not very far from the mine stands an ancient stone cross, called, after the name of the estate on which it is situated, Pradanack

1 A specimen of native copper from this mine, weighing $15 \mathrm{cwt}$., was sent to the Great Exhibition of 1851 . The works of the mine have, however, been again abandoned. 
Cross. It is five feet and a half high, and the base is inserted in a stone slab. The sites of two ancient chapels are also pointed out in different parts of the parish, but all remains of the structures have long disappeared.

Mullion Church is distant about two miles and a half from the cove, and as it stands on high ground is a conspicuous object from all parts of the bay. Over the western door is carved a crucifix, with the Virgin Mary and the beloved disciple standing at the foot of the cross. Within, the church is partly fitted up with open seats of ancient carved oak, the figures on some of which represent the instruments of torture used at our Blessed Saviour's crucifixion. In the chancel is the following quaint inscription :-

\section{"Thom. Flavel, Vicar of Mullion, DIEI) I682.}

Earth, take thine Earth, my Sin let Satan havet. The World my goods, my Soul my God who gavet; For from these four, Earth, Satan, World, and God, My flesh, my sin, my goods, my soul, I had."

This Thomas Flavel, during his life, attained great celebrity for his skill in the questionable art of laying ghosts. His fame still lingers in the memories of the more superstitious of the inhabitants through the following ridiculous stories. On one occasion, when he had gone to church, his servant-girl opened a book in his study, whereupon a host of spirits sprang up all round her. Her master discovered this, though then occupied at church, closed his book and dismissed the congregation. On his return home, he took up the book with 
which his servant had been meddling, and read backwards the passage which she had been reading, at the same time laying about him lustily with his walking-cane; whereupon all the spirits took their departure, but not before they had pinched the servant-girl black and blue. His celebrity, it seems, was not confined to his own parish, for he was once called on to lay a very troublesome ghost in an adjoining parish. As he demanded the large fee of five guineas for his services, two of the persons interested resolved to assure themselves, by the evidence of their own eyes, that the ceremony was duly performed. They accordingly, without apprising one another of their intention, secreted themselves behind two graves in the churchyard, a short time before the hour named for the absurd rites. In due time the ghost-layer entered the churchyard with a book in one hand, a horsewhip in the other. On the first smack of the whip the watchers raised their heads simul. taneously, caught a glimpse of each other, and were both so terrified that they scampered off in opposite directions, leaving the operator to finish his business as he might. So popular are superstitions of this kind, and so long do they linger, that to the present day a spot is pointed out on the downs named "Hervan Gutter," where Thomas Flavel's own ghost was laid by a clergyman, of whom he had said before his death, "When he comes I must go."

The parish of Mullion is remarkable for the longevity of its inhabitants, it appearing from the register, that out of 75 persons buried within the twelve years previous to I 848 , no less than fifty- 
three exceeded the age of seventy, and of these, eighteen were upwards of eighty at their death, and seven upwards of ninety. The same familynames are found in the parish now as occurred two hundred years ago, and there has always predominated an unaccountable fondness for high-sounding classical and scriptural Christian names; such as Hannibal, Zenobia, Dionysius, Erasmus, Marina, Renatus, Joel, Jeremiah, Aserath, Theophilus, Demetrius, Thirza, Abraham. It is difficult to conjecture whence the former of these at least were derived.

Until recently, since the activity of the coastguard and preventive service have rendered the occupation precarious, smuggling was universally practised. Few families were not more or less engaged in it, either in the person of one of their members or by a pecuniary venture, and many of the houses had, and still have, though they are now disused, secret underground chambers, which can be entered only through the parlour cupboard, which is furnished with a false back. Old grey-headed adventurers still talk with evident pleasure of the exciting occupation of their younger days, and of their frequent hair-breadth escapes, and occasionally contrive to run a cargo, even in the existing state of things ${ }^{1}$; but in the times which they can recollect, as many as seven or eight vessels, laden with smuggled goods, have been off the cliffs at one time, wind-bound. One sturdy veteran in particular, who, since he has dropped his profession of smuggler, has on many

1 This was written in $18_{4} 8$. 
occasions risked his life in the effort to save the crews of shipwrecked vessels, can tell a tale of his being chased by a king's boat, of his having thrown himself overboard, of having swum for his life, of his having eluded, by diving, blows dealt by an oar or a cutlass, and of having escaped safe to land. The rowers who pursued may not have put forth their utmost strength, and the blows may have been aimed with purposed inaccuracy: for in those days there were many sailors in the navy who had served their apprenticeship to the sea while practising the same lawless pursuit, and such would willingly connive at the escape of a brother craftsman.

I can myself recollect having conversed, some forty years ago, with a coastguard-man who had formerly been a smuggler, and had with his comrades been captured by a revenue cutter. $\mathrm{He}$ and another were tried and convicted, and sentenced, as was then customary, to five years' service in the navy. While on board the vessel in which they were to proceed to a foreign station, anchored at Spithead, they escaped from confinement and threw themselves into the sea by night, with the intention of swimming ashore. They had not, however, gone far when they were descried by the sentinel on board, who gave the alarm, and they were fired at. My informant reached the shore in safety, hid himself for a short time, and being afraid to return to his own neighbourhood, entered into the preventive service, and was, at the very time that I saw him, after the lapse of some years, visiting his friends in his native village, and close to the scene of his 
early feats of daring. His comrade was not so fortunate; either he was struck by a bullet, or became exhausted before he reached the shore and was drowned. At all events, he was never seen again.

About the same period, too, I was, one fine summer evening, loitering about the beach, near a small fishing village, in a remote part of the county. It was about four o'clock, the sea was as smooth as glass, and the wind so light, that whatever vessels and boats were in sight were either stationary or sluggishly impelled by oars. One fishing-boat only, about a hundred yards from shore, had its sails hanging idly from the mast, but yet appeared to be creeping towards a quay which ran out between the beach, on which I was standing, and the houses in which the coast-guard resided. At the very instant that she had advanced so far that the pier was interposed between her hull and the houses, I observed a great splashing caused by something repeatedly thrown into the water from the boat, and a number of men rushed down from the houses, dashed into the water up to their middles, and scampered up the beach with a $\mathrm{keg}$ in each hand. In the scuffle the boat capsized, but as she was in shallow water, no mischief ensued, and in the course of a few minutes two or three peaceable orderly fishermen were quietly setting her to rights, and mooring her for the night. Some ten years afterwards, a fisherman of the same village was taking me on a cruise in his boat, when I asked him whether there was any smuggling now at-? His reply was singular 
enough: "The last cargo that was run was my venture, and with my boat, ten or twelve years ago ; we brought over I 50 kegs, and landed them on a fine summer's evening at four o'clock, close under the preventive-houses. They thought then that we always chose stormy weather and dark nights to land our goods, but we tricked them. The risk, however, was very great, and I believe that no one has ever ventured since."

For the following narrative I am indebted to the Rev. F. Gregory, who has also supplied me with a good deal of other information connected with this part of the coast. Many years ago, a Mount's Bay boat, commanded by a man nicknamed "Billy of Praow 1," ran ashore at Mullion Cove with a cargo of French brandy. The Hecate gun-brig, was then stationed in Mount's Bay, and suspecting what was going on, despatched a boat to take possession of the smuggler. The crew of the latter being taken by surprise, made little or no resistance, and abandoned their prize. The country people, however, being informed of the fact, collected in large numbers along the cliffs, and firing upon the captors from behind the rocks, compelled them in their turn to relinquish their booty, and return to the ship. Many of the most respectable persons in the parish engaged in this lawless

1 The Cornish, especially in the mining districts, are particularly fond of giving each other nicknames. I have heard a story told of a woman, who, when her husband was inquired after by his real name, did not know who was meant; so thoroughly had she grown into the habit of addressing him by the fictitious epithet. 
enterprise, and though they were threatened with prosecution, the matter was hushed up. About eight or nine years ago my informant was called on to visit ministerially one of the most active persons concerned in this affray, then an old man lying on his death-bed. Being talked to about his religious belief, and questioned as to his acquaintance with the Sacred Volume, he confessed his utter ignorance of the contents of both the Old and New Testaments, and, as a natural consequence, of the duty of a Christian. The only passage in the Bible of which he had any knowledge was the sixteenth verse of the twentyfourth chapter of Ezekiel: "Son of man, behold I take away from thee the desire of thine eyes with a stroke: yet neither shalt thou mourn nor weep, neither shall thy tears run down." Being asked to account for the strange fact that this passage rested on his memory while he was nevertheless unable to repeat one of the simplest declarations or promises of the Gospel, he said, "that when he was a boy living in farm-service at Gunwalloe, his mistress died suddenly, and the clergyman of the parish coming to see his master, asked what text he should choose for the funeral sermon, which he intended to preach on the following Sunday. He overheard his master answer in the above words, which made a lodgment in his mind, and came back to his recollection after seventy years or more of reckless, unsettled living, when everything else relating to religion, if ever learnt at all, had been entirely forgotten." This anecdote not only shows the indelibility of religious impressions reccived in youth, however 
slight they may have been, or however unproductive of good results; but, if the ignorance which it indicates be characteristic of a class and not merely of an individual, sufficiently accounts for the impossibility of convincing smugglers that their occupation is not only lawless but sinful.

The fishery at Mullion was formerly very productive. In the year 1806 or $1807 \cdot a s$ many as 7,000 hogsheads of pilchards were taken and cured. These were summer fish, and were shipped for the Mediterranean in autumn. Winter fish were first taken about sixteen years ago, from which time the pilchard boat began to put to sea twice a year. Of late years, however, the visits of the summer fish to the shallow water have been rare, and shoals are now not often enclosed in the seine except in winter.

By the kindness of Lord Falmouth I have been put in possession of a list of shipwrecks which have taken place between Mullion and Gunwalloe from I8I7 to the present year (I874). They amount to thirty. Of some the crews were saved; others lost one or more hands. The total of lives known to have been lost is I 86 .

From the mournful catalogue I select three, and give the following particulars on the authority of the Rev. E. G. Harvey, Vicar of Mullion.

On the morning of the $25^{\text {th }}$ of March, I867, information was brought to the Vicarage that during the night, which had been tempestuous, a large vessel had gone ashore, and that a number of persons had been drowned. The rocket apparatus was at once got out and hurried down 
to Poljew Cove (Mullion was not then a Lifeboat Station) thence on towards Gunwalloe; but nothing was to be seen of any vessel. Meanwhile some of the villagers had gone along the cliff-tops between Polurrian and Poljew, and there they discovered portions of a wreck. Clambering down the rocks, they fell in with the sole survivor of the unfortunate vessel, a Greek sailor. He was so bruised and benumbed that he could have given no intelligible account of the wreck even if the coast-guard could have understood the little English he was master of. Soon the stern of the vessel was found, washed in between two ledges of rocks on the southern side of Poljew Cove, and near it the bodies of three females, an infant, and a sailor. These were all taken and laid in the tower of Mullion Church, to await a coroner's inquest.

The Greek sailor having been clothed and fed, was questioned by the Vicar, but seemed little inclined to be communicative; and his ordinary language-a patois of Greek and Italian-was hard to be understood. He said he had joined the ship at Batavia, but he did not know her name nor that of the captain. He had on him a lady's gold watch and chain, but failed to account for the way by which these articles had come into his possession. There were twenty-five souls on board at the time of the wreck, and he added that this was the third time he had been wrecked and had been the sole survivor. When the vessel struck, he, with two other sailors, were on the jib-boom; all three sprang on to the face of the cliff, two being by 
the next wave sucked back into the sea and drowned. He himself held on, managed to scale the cliff in spite of the darkness, and then wandered about till he was found by the coastguard and villagers.

Along the shore, coffee-berries were washing in large quantities, and piles of bamboo sugarbaskets were to be seen lying by the water's edge in every direction. Tons of the coffee were collected and carted away to Penzance, only to prove a bad speculation to the purchasers. Coffee-bags laid down as mats may still be seen on many a cottage lime-ash floor, and bamboo-stakes from the sugar-baskets still form the fence of many a cottage-garden. A portion of the cargo was tin, which was subsequently fished up by means of long tongs, at a remuneration of $£ I 5$ per ton; and many weeks after the wreck a strong box was recovered, containing money to the amount of about $£ \mathrm{I} 2,000$.

In the course of subsequent inquiries it was found that the ill-fated vessel was the Johnkheer, of Dordrecht, Captain Klaas Lammerts, 650 tons register, homeward bound with a cargo of sugar, coffee, spice, and Banca tin, and that her estimated value with cargo was between $£ 40,000$ and $£ 50,000$.

The history of the lost passengers was investigated, and proved to be not untinged with romance. The baby, with its "little cap, nightdress, and pink coral necklace," was the child of one of the young women washed ashore, the captain's wife, and was some three weeks old. Of the money a third part was awarded to the 
salvors; the remainder was made the subject of litigation, and was mostly swallowed up in law expenses.

The Greek sailor was examined by the local magistrates, who, however, could prove nothing against him. The villagers suspected him of foul play, and hated the sight of him. He went away, no one cared whither; but none of the villagers then living will ever forget him.

The above account is condensed from $\mathrm{Mr}$. Harvey's narrative; the two others I will give in nearly his own words.

"Lo'ss of the brigantine Jose Oscar, of Bayonne, at Gunwalloe, Oct. I7, I862.-Weather wild and stormy; heard that a vessel whirh was embayed would certainly be driven on shore or come in at daybreak. Went down as soon as I could see. It was raining fast and the wind was very violent. The roaring of the water and heavy breakers striking full on the rocks seemed to shake the land. Upon reaching the cove the vessel came, dragging her anchors, on to the beach broadsides. The rockets were fired, but the wind always sent the line back again; and the sea was rising and rolling waves clean over the vessel as high as her yard-arms, flying up over her pennant. At last they managed to pass a line to her with the cradle-apparatus, into which one of the crew quickly got; but as quickly the captain got him out, and put in first the oldest hand on board, the captain himself leaving the last, and coming ashore with his purse between his teeth. All were rescued. None of them could speak English. Warm clothing and re- 
freshment soon restored them. The vessel shortly afterwards was torn to pieces by the shocks from the waves, and became a total wreck. The poor fellows, as soon as they were able, embraced their deliverers, and by gesticulations expressed their thanks in a most graceful and affecting manner."

"Loss of the smack Maria Louisa, of Padstow, on Mullion Island, Jan. 22, I868.-Weather frightful, continuing through the night and next day. Up before daybreak, heard of a vessel being off the island which would certainly become a wreck. The rocket-men and apparatus just then dashed through the village at full speed, when all who could, ran after them as fast as the violence of the gale would permit them (the wind being west and dead inshore), and the foam, which was then flying in the air right up into the village. Half-a-mile off was the cove, from which sounds were continuously coming in shocks like peeling thunder. Reaching the spot at last, I found all the lifeboat and rocket-men there, and ready, but looking very grave; for the vessel had struck Tregwin-rock, on the edge of the island, and instantly disappeared with her crew. They could give no help, nor could they launch the life-boat in the front of such a sea. In the cove none could stand without holding to or sheltering behind a rock. The spectacle was most awful; the storm then in all its fury-sky dark as ink - foam white as snow-and the driven spray blinding. Masses of wave were following one upon another, having wall-like fronts nearly perpendicular, which, rising over, fell with their 
whole weight in the inlet, upon the mouths of the caverns and rocky precipices, with a force that, I thought, shook the solid rock I held by. Upon the island itself in front the mighty waves broke, and, rising high in the air over all, fell again in cataracts with a fearful roaring. All said they never saw the sea like that before.

"Sometime afterwards there came ashore a part of a compass-box, a sail, a shirt, a pair of socks, and a piece of board with the letters SA PADSTOW painted upon it, and this, I believe, was all that was found of the smack Maria Louisa.

"At the above time, round the headland in Polurrian Cove, was lying the wreck of the Achilles, which had been driven ashore on the 2Ist of October, I86\%, and dashed to pieces. The cargo, I,500 tons of timber sawn up into scantlings, strewed the shore."

Of this the short account is less harrowing. "Barque Achilles (captain, David Kinnear) at Polurrian: all hands saved by life-boats and rockets."

Proceeding from Mullion Cove, we ascend a steep acclivity, and passing a flagstaff, the signal station of the coast-guard, observe several tall posts fixed in the turf. These are intended as boundary-marks for the fishermen in the pilchard: season. The shore beneath is sandy and weil adapted for shooting the seine, and in order that all parties may have equal chance of a catch when the pilchards are on the coast, each company takes its station on the best ground for a definite time, and then resigns it to another. 
A short way further on, the ground rises into a fine peak of slate rocks, rudely piled together and commanding a glorious view of the Mount's Bay. It has been named "the Cathedral," partly from its pinnacled character, and partly from the following incident. Some years since an Irish Roman Catholic in the coast-guard service, who had been forbidden by his priest to attend divine service at the parish church, was in the habit of spending the greater part of every Sunday on this spot. Here he read and meditated, and as he, no doubt, believed he was doing right in refusing to worship with those whom he had heard denounced as heretics, the alternative which he chose can scarcely be considered culpable.

The sandy cove, a little to the right, is Polurrian Cove, as we descend to which we have an exceedingly beautiful view of Mullion Island, with its strongly-marked outline reseinbling some enormous animal couching in the sea, whilst the broken cliffs beyond are scarcely less striking. A narrow, winding path leads down to the sands; about a third of the way down, in a little natural hollow sheltered from every wind that blows, a long, narrow mound points out where rests at length some sea-tossed mariner, all that is known of whose history is, that here his corpse was washed on shore, and here consigned to the grave. Common though the occurrence of burial-places is on these cliffs, there is something particularly touching in this lonely grave of the unknown wanderer. The last wreck attended with extensive loss of life, at this cove, previously to the 
wreck of the Jolnkheer took place in the night of the 20th of June, I838, when a Neapolitan vessel of I 80 tons burden was driven on shore and all her crew perished. Nothing was known of the occurrence till next morning, when the shore was observed to be scattered with pieces of wreck, and in the course of a few days eleven bodies were picked up and buried in the churchyard.

A mile further on is the sandy cove of Poljew. Here a wreck took place many years ago, and the yeomanry cavalry being, as was then usual, called in to prevent depredations, a miner from one of the inland parishes was killed in a scuffle. Much more recently a Norwegian vessel laden with Indian corn was driven on shore, in the night, on a rock to the right of this cove. The vessel almost instantly went to pieces. With great difficulty three of the crew, who were washed against the base of the cliff, climbed to the top, and proceeding inland, were hospitably entertained at the first cottage which came in their way. At dawn of day they returned to the coast to search for their comrades, though their hopes were but small. As it grew lighter something dark was observed in a crack of the rock, and immediately afterwards a slight motion was perceived. Three men were eventually descried huddled together, but so exhausted as to be unable to make any effort to save themselves. By dint, however, of great exertions, and the daring skill of the people on shore (among whom the old smuggler mentioned above held a prominent place), a small cord was thrown across, 
the end of which the poor shipwrecked mariners contrived to make fast. By help of this communication, hot coffee and bread and butter were conveyed to them. This refreshment and the renewed hope of preservation strengthened them to renewed exertion. In the course of a $\mathrm{f} \in \mathrm{W}$ hours a stronger rope was fixed, and a kind of rude chair made to slide over to them, in which they were one by one brought safely to land, after having been for ten hours exposed not only to a cold wind, but to the action of the sea, which dashed over them at very short intervals. The rest of the crew, six in number, were drowned. For more than a fortnight after, the shore was crowded by poor people fishing up the damaged corn, which, though unfit for human food, found ready purchasers among those who kept pigs. People came from a distance of ten or twelve miles to the scene of this wreck, and the various roads diverging from the spot were for a long time sprinkled with Indian corn, which had fallen from their carts or bags.

On leaving Poljew, we find the character of the coast altering; the cliffs are less lofty, and the land sweeps away to the west in a succession of undulating sand-hills. As we descend, Gunwalloe Cove and Church open on us, the former as delightful a spot in which to spend a long summer's day as can be well imagined; the latter an ancient structure, said to have been erected as a votive offering by some rescued mariner. The churchyard walls are washed by the sea; the unpretending belfry is detached from the church, being built against the side of 
a hill which rises between it and the sea. On the point outside formerly stood a stone cross, where it must have been the first evidence of human workmanship which presented itself to any one approaching the land. It has long been thrown down, and is said to be now lying at the bottom of the stream which winds its way down

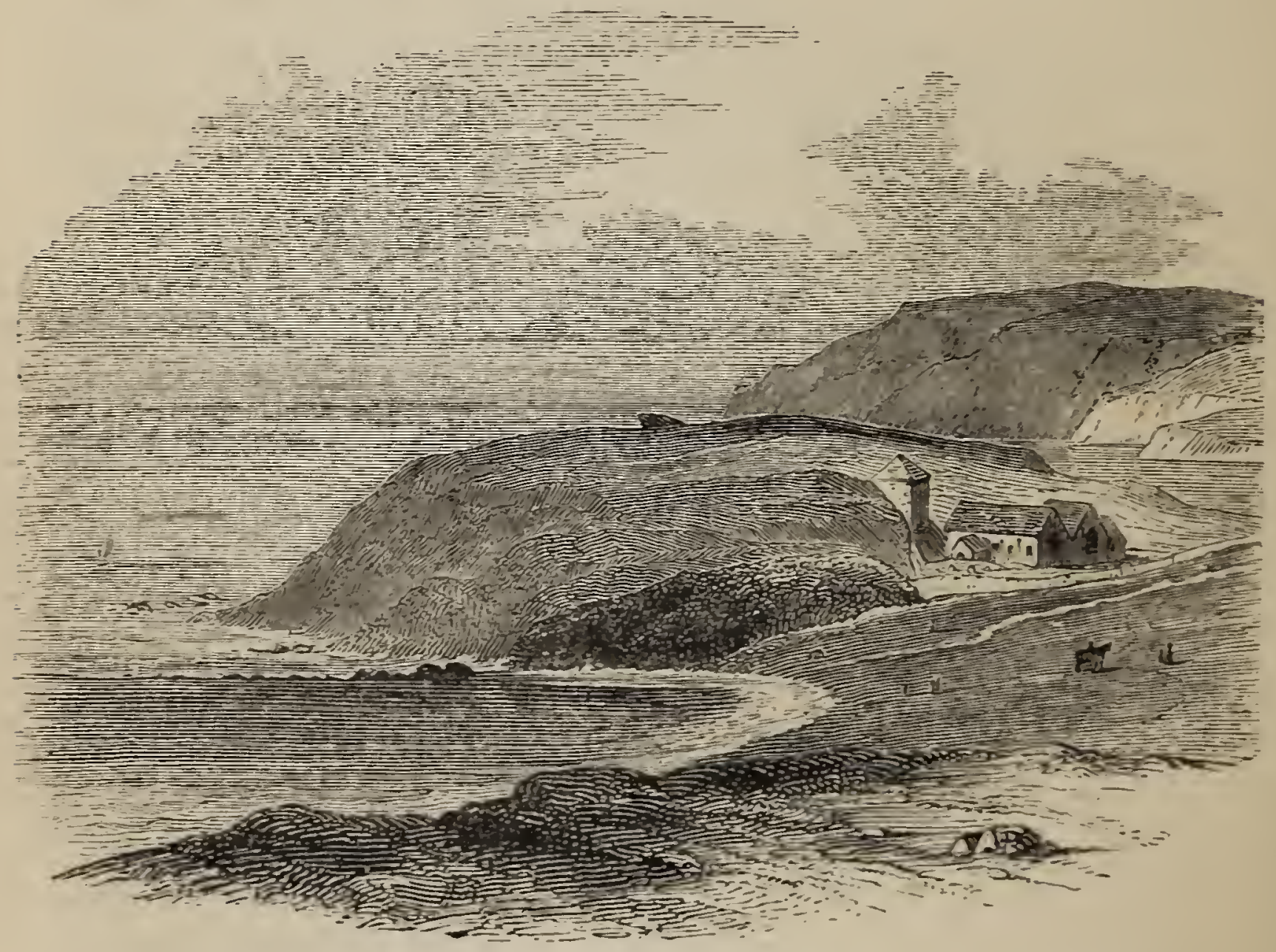

GUNWALLOE CHURCH.

the valley. If this be the case, it is much to be hoped that it may soon be restored to the spot where it was piously erected. In the absence of all record, it may be conjectured with some plausibility, that the rock on which it stood was the very one on which the founder of the church secured his footing after his shipwreck. If it be, 
as some maintain, a superstitious feeling which leads to the restoration of crosses, that superstition is surely laudable which would commemorate the fact that an unknown Christian, who lived in days beyond the memory of man, here gave glory to God for an act of mercy in saving him from sudden death. ${ }^{1}$

A rather wide valley runs up from Gunwalloe Cove, with so gradual a rise, that a great part of it is marshy; the little river which flows through it appears in many places to be almost motionless. It is lined, and sometimes almost filled, with flags and other aquatic plants, among which the great spear-wort, ${ }^{2}$ a rare plant in the south of England, is very conspicuous.

Beyond Gunwalloe Church, the land rises and the coast again becomes bold for a short distance. The cliffs, though not lofty, are precipitous, and offer no chance of escape to any unfortunate vessel which may chance to be driven in within reach of the rocks. About the year I785, a vessel laden with wool, and having also on board two and a half tons of money, was driven ashore a few hundred yards west of the church, and soon went to pieces. Ever since, at intervals, after a storm, dollars have been picked up on the beach, but never in sufficient numbers to compensate for the time wasted in the search. No measures, however, on a large scale for recovering the precious cargo were adopted until the year I 845 , when people were startled to hear that a party of

1 This church has been recently enlarged.

${ }^{2}$ Ranunculus Lingua. 
adventurers were going to sink a dollar-mine in the sea. ${ }^{1}$ The vessel had gone to pieces between two rocks at a short distance from the base of the cliff, and here it was proposed to construct a kind of coffer-dam, from which the water was to be pumped out and the dollars to be picked up at leisure. Mad though the scheme was, operations were actually commenced; a path was cut in the face of the cliff, iron rods were fixed into the rocks, and several beams of timber laid down, when a breeze set in from the south-west, and in the course of a few hours the work of as many weeks was destroyed. The wood-work was ripped up as effectually as if it had been a mere wickercage, and the coast was soon lined with the fragments. It is not likely that the attempt will be renewed. The speculators were in this instance strangers, which accounts for the enterprise having been taken in hand at all; for any one acquainted with the coast must have been well aware, that although the sea is sometimes tolerably calm for many consecutive days, it never is so for a period long enough to allow the completion of a work which requires time, and which, in the most favourable weather, is beset with difficulties; indeed, an ordinary breeze setting on

1 This is not the only unsuccessful search for treasure which has been made at Gunwalloe. In the sand-banks near the church (or, as others say, at Kennack Cove), the notorious buccaneer, Captain Avery, is reported to have buried several chests of treasure previously to his leaving England on the voyage from which he never returned. So strongly did this opinion prevail, that Mr. John Knill, collector of the customs at St. Ives, procured, about the ycar 1770 , a grant of treasuretrove, and expended some money in a fruitless search. 
this shore excites the sea to such a state of fury, that certainly no unfinished mechanical structure could withstand the force of the breakers.

The piece of land west of the church terminates in a promontory, which maywell be distinguished by an insulated rock, shaped like a haystack. The side facing. Mount's Bay is scarped by a shelving cliff of slate, and since it looks towards the west, and commands an uninterrupted view of the bay, is an excellent point from which to watch a fine sunset. One which I observed here is too strongly imprinted on my memory to be forgotten. It was at the close of a very hot day in July, still and cloudless, and I was walking from Mullion to Helston, having quickened my steps to be in time to see the sun go down from the Halzaphron Cliffs, as they are called. When I reached this point, the sun was within a few degrees of the horizon, but shining brilliantly here and over several miles of sea to the westward: beyond this all was wrapped in an impenetrable mantle of mist. I could only discover that the two boundaries of the bay were simultaneously subject to two atmospheric influences, as different from each other as summer and winter. Where I stood the air was clear, bright, and still ; what little motion of the wind had been perceptible during the day was from the east or south. Towards the Land's End, the sun slowly descended behind a mass of dense mist, which, as he disappeared, assumed the deepest of all possible blue-purple hues, with a narrow welldefined edge of gold, or rather of liquid yellow fire. The mist in front caught none of these 
tints; but from the shore, a little beyond the fishing village of Porthleven, it rolled on rapidly in white filmy clouds from the north, as if it knew that the melting beams of the sun were now withdrawn, and were anxious to occupy as soon as possible the station where it was to hold sway during the night. In a few seconds every bright tint had vanished, the whole mass of clouds, for such they had now become, was of a dull whitish grey colour; as far as the eye could reach it looked down on the uneven masses moving like tops of the trees in a forest during a tempest. A few seconds more, and a chilling north wind blew in my face, and accompanied me during the remainder of my walk. What particularly struck me on this occasion, was not so much the shifting character of the scene, as the extraordinary rapidity of the change, which was much greater than that which usually accompanies the operations of nature. The contrast was as great as exists between midday and midnight, and the whole took place during the time that the sun was descending through a portion of the sky but a little greater than its own diameter. I could compare the effect on the mind to nothing but that produced by a brilliant display of fireworks ; but even this comparison fails in one respect, for, to be exact, the display should commence in broad daylight, last but for a few minutes, and yet terminate in gloom. I afterwards heard that some persons who were tempted by the bright appearance of the morning to plan an evening expedition to the Bishop-Rock (the singularlyformed rock mentioned above, less than two miles 
west of Portleven), carried their design into execution, but could distinguish nothing, owing to their being enveloped in the mist. So variable and uncertain is the climate of Cornwall.

About sixty years ago a transport was wrecked under the Halzaphron Cliffs, and a great number of lives were lost. The bodies of thirty seamen and militarywere buried near the spot where they were washed ashore, and this is the last instance of burying the corpses of shipwrecked persons in unconsecrated ground. In consequence of the strong feeling excited on this occasion, the late Mr. Davies Gilbert introduced into Parliament an Act sanctioning the burial of bodies thrown up by the sea in the parish churchyard, the expenses attending such interment being defrayed out of the county rate.

A little to the west of Halzaphron is the fishing village of Gunwalloe, and from hence a long line of beach, composed of small pebbles, extends to Porthleven. About midway across, the high land suddenly sinks, and forms a basin for the Loe Pool, the largest lake in the west of England. There are so many peculiarities connected with this body of water, that the tourist will find it worth his while to devote a few hours to surveying it. It is formed by several small streams which descend from the hills around in various directions, the largest, called the Cober, flowing by the town of Helston, which is situated near the head of the lake, and is visible from the sea, from which it is distant about three miles. The lake is separated from the sea by a belt or bar of small pebbles, which at low-water is perhaps three or four 
hundred yards wide. Its structure being loose, it allows the water to percolate freely, so that, unless the season be very rainy, the lake does not vary greatly in extent; the average surface is a hundred and sixty-three statute acres. In winter, however, it frequently happens that the quantity of water brought down from the hills exceeds to such a degree that which is strained off through the Bar, that the lake extends into the lower part of the town, floods the road and even some of the houses, and stops the town mills. When this takes place, the parties interested proceed to Penrose, the manor to which Loe Pool is attached; and delivering to the lord a leathern purse containing three halfpence, request permission to cut through the Bar. This task is frequently much more laborious than one would imagine; for when a channel four or five feet wide has been dug from the lake to the sea, and a copious stream of water rushes into the opening of the channel, so loose is its gravelly bed that before the water has traversed twenty feet it sinks into the soil and disappears. Efforts are made to meet the difficulty by widening and deepening the mouth uritil a communication between the fresh and salt water is established. Then, nothing more remains to be done: in a few hours a deep, mighty river is bursting out with inconceivable velocity, and engaging in violent conflict with the waves of the ocean; as the two meet they clash together with terrific uproar, while the sea for twenty, or even thirty miles, is tinged of an ochrous hue. Even at the Scilly Islands the cutting of the Loe Bar has been 
notified by the altered colour of the water. In a very few hours after the torrent has reached its height, a great part of the bed of the lake may be traversed on foot; the eastern creek called Carminowe alone retains a large body of water, and a river of considerable depth still flows out through the channel. Sometimes the mouth of the channel is not closed again for many days, during which the tide cbbs and flows into the lake. But if a storm comes on from the west or south-west, the breach in the Bar is soon repaired, and not unfrequently enough salt water is shut in to impart a brackish flavour to a part of the lake for several months after. It is rarely necessary to break the Bar twice in one year, sometimes not even once; but the walls or banks of pebbles which lined the old channel commonly remain until the next time of cutting. In the winter months, too, the sea, during a storm from the south-west, makes a breach over the Bar, so that it is not unusual to find seaweed and the broken corks of nets lying on the edge of the lake a long way up. If a large quantity of salt-water be thrown in, the necessity of cutting the Bar is accelerated. While the channel remains open, herrings, flounders, and shrimps find their way into the lake and are shut in; a marine plant, also, Ruppia maritima, flourishes in Carminowe Creek. The Loe Pool formerly abounded in trout, but of late years they have become almost extinct, owing to the quantity of mineral waters discharged into the lake from the Wendron mines. The Treville family formerly held lands near Helston by the service of providing a boat and 
nets for the king's use in Loe Pool, during the whole time of his stay, whenever he should visit Helston. This tenure goes far to prove that the celebrity of the Loe trout is of ancient standing. History, however, does not record before which of our kings the dainty dish was ever set. Nansloe, another estate adjoining the Loe, is held on con-

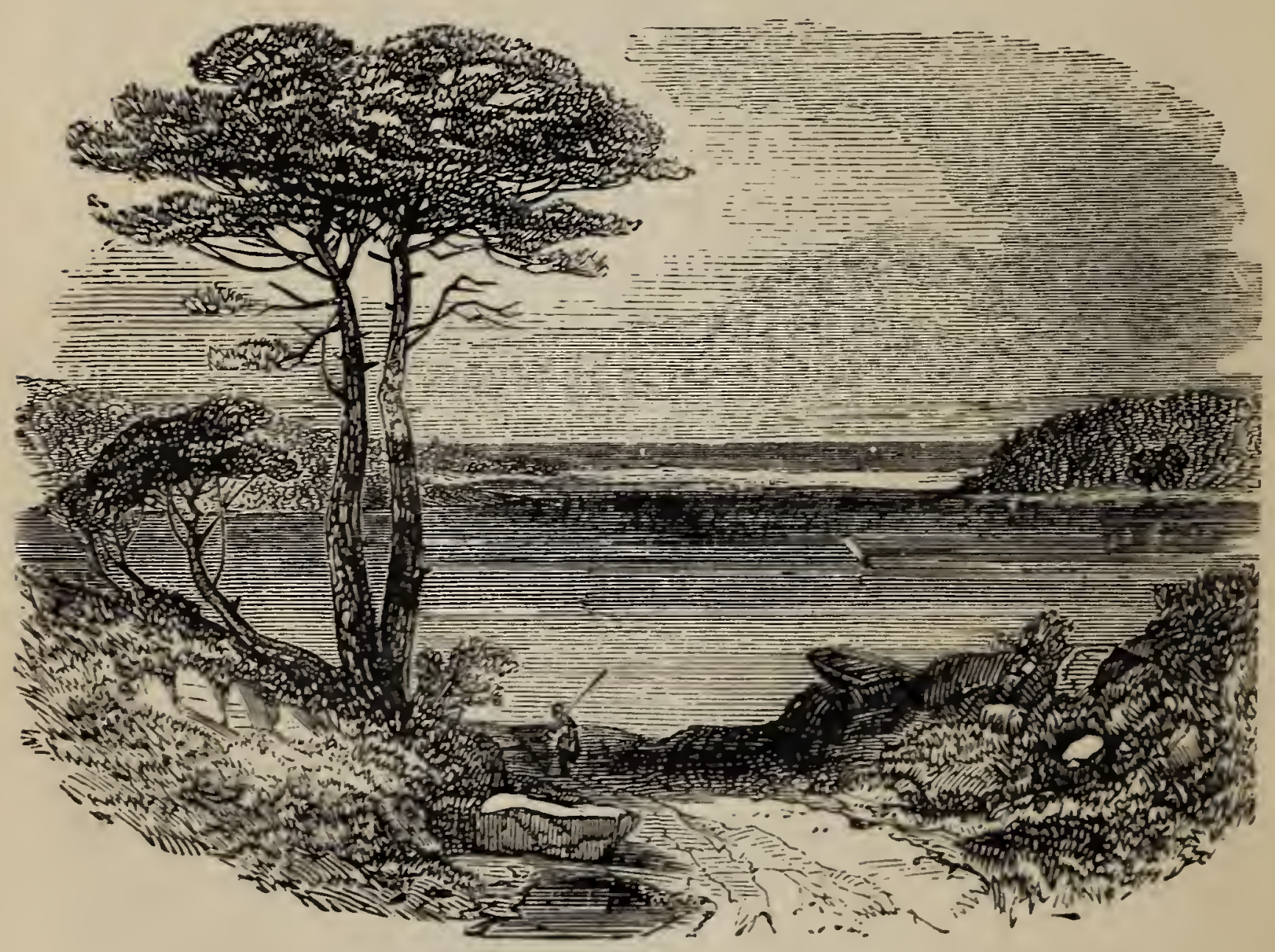

LOE POOL-from Degibna Wood.

dition of providing a boat and nets for the Duke of Cornwall whenever his Royal Highness visits that part of his Duchy.

Penrose, the seat of John Jope Rogers, Esq., is situated on the western side of the Loe. The walk through the park, from the Bar to Helston, is particularly pleasant, being lined a great part 
of the way by ancient stunted oaks of most fantastic growth, and at other parts being carried through flourishing plantations, composed of trees judiciously selected as being able to resist the sea-breeze, and which greatly improve the features of the landscape. Among them Pinus Austriaca is one of the most valuable trees for shelter and ornament that has ever been introduced into Cornwall.

Rather more than a centuryago, a transport with troops on board, bound for foreign service, having been driven by stress of weather into Plymouth harbour, the neighbouring gentry invited the officers to a grand ball. Amongst those present was the young heiress of Penrose, in the county of Cornwall, who, on being asked if she wished to dance with any of the officers, replied- "You may introduce me to any of them except that ugly Scotchman." The officer thus designated was Lieutenant Alexander Cumming, a younger son of the Altyre family. In the course of the evening, however, Cumming got introduced to the heiress, and so captivated her that in a few weeks she became his wife. He afterwards retired from the army and settled at Penrose. ${ }^{1}$ The following letters were written by him to his uncle, George Cumming, of Altyre. His losses, through those "Vultures "- the lawyers, appear to have been amply compensated by "the God's Blessings."

1 His eldest son, Alexander Penrose Cumming, eventually succeeded to the Altyre and Gordonstown estates, and was created a baronet. 


\section{("Penrose, Feb. 27th, I 757.)}

"DEAR SIR,-I make no doubt but you'll be surprised at not having heard from me sooner, but I have been so plagued and harrassed of late by a sett of Villains (I mean Lawyers, who, by the by, are the Curse and Scourge of this Country), who have not only engrossed my time, enraged my Temper, but what's worse then all the rest, Exausted my money, and I'm sorry to say that I have been obliged to live in a state of warfare ever since I came into this Country, as every man must do here that would preserve his property, and more especially a stranger. Nor will you wonder at this, when I inform you that in the Town of Helstone, which is a little bigger then Elgin, there are I 5 or I6 Attorneys, and the Gentlemen of the Country are so sensible of this growing Evil, that there is scarce one of them, but breeds his Son a Lawyer, to enable him to keep his Estate from the other Locusts of the profession. But to give you a better Idea of their iniquitous proceedings, I'll lett you know the Affair that has embarrassed me so much of late. You must know that my Predecessor, Mr. Penrose, bequathed a Legacey of $£$ Ioo to a servant maid, that lived with him at the time of his death; this Wench married a fellow at Helstone who soon afterwards bankrupted and run away, but first assigned the Legacey to his father, an old man of infamous Character. Soon after the Father demanded payment of me, upon which I paid him part and would have paid the whole, but was Advised that it would not be safe to pay the rest of the money, unless the Son 
would joyn with the father in giving me a Release or discharge; but, instead of that, when the Son returned he absolutely forbid me, at my peril, to pay his father any more, alledging that the other had cheated him out of the Assignment, and that if I payed him any more, he would oblige me to pay the money over again. In this Situation I refused paying any more, unless both joyned in Releasing me; when one of those Miscreants, above-mentioned, advised the Old Man to Commense a Suit in Chancery against me and his own Son; upon this my Counll. Represented the Case as above, setting forth that I had always been ready and willing to pay the whole upon being properly discharged, \&c., \&c. But, notwithstanding the reasonableness of this Argument, they obtained a Decree, which obliges me not only to pay the prinle. and Intrst., but likewise all their Costs, as well as my own. I shall only give you one Instance more of the Villiany and Oppression of these Blood-Suckers. Mr. Penrose, some years before he died, borrowed $£ 500$ of a Gentlewoman in this Neighbourhood, and gave her for Security a Mortgage of an Estate worth 3 times that Sum. Soon after his Death, and during my wife's Minority, one of those Villians perswaded the Woman to demand her money of the Trusteesone of whom, you may remember, I told you was also an Attorney himself. This Brother of Iniquity pretended he could not Justifie paying the money without the direction of the Court of Chancery, tho' he had three times that Sum in his hands at the same time, upon this the other 
brings four severall Actions in the Courts of Westminster for Recovery of the debt, notwithstanding he was in Actuall possession of the Estate; and lastly, he commenced a Suit in Chancery. Now you must know the more Actions the One brought, the more the Other had to defend, so that between them the Estate would have been tore to pieces had She not luckely Married at that juncture; and it was even with the greatest difficulty that I could extricate myself from these two Vultures, who by their joynt and Exorbitant Costs had Swelled the debt to upwards of $£$ I 200 Ster., which sum I was also obliged to pay. It's true I might have Taxed their bills in the Court of Chancery, but I was credibly informed the Remedy would be worse than the Disease.

Thus have I been harrassed and distressed by a Sett of Wretches who are the Bane of human Society, and particularly the Curse of Cornwall. But you'll be surprised after this long Exclamation to hear that I have some thoughts of breeding One of my Sons to that very profession, but not with an intention that he may Oppress his fellow-creatures, but that he may preserve his own and his family's property; however, in this, as in everything else, I shall be advised and directed by you. We are still flattering ourselves with the hopes of seeing you here this Summer, a pleasure I'm the more sollicitous about, as I'm certain your presence here must be productive of many real advantages to us; and as the Adjustment of our Affairs requires a much clearer head and abler hand than mine to direct 
them, so I hope the preservation and welfare of this family would be a sufficient Excitment to you for undertaking a more Ardous Task then a jurney to Cornwall ; and in your way here you'll have an opportunity of getting Provost Brodie's Acct. settled, the Ballce. of which I would gladly have Remitted before now, but can have no Ansr. from Mr. Chambers to whom I sent it. I cannot conclude without assuring you that it would give me great pleasure to write you much more frequently then I do, but that it's with the utmost difficulty I can obtain franks, for out of 44 Membrs. which this County sends to parlmt., there is not 4 that Resides in it. I expect every hour my Wife will make me a present of another Boy. She joyns in kindest Compts. to you with him who is, Dear Sir, your faithful and affect. Nephew and Servt.,

"A. Cumming."

"DEAR SIR,-In my last I sent you enclosed a Rent Roll of this Estate, but I forgott to mention one thing which is a very considerable Apurtinance belonging to it, viz., a Royallty on the Sea Coast, which generally keeps my Cellars well Stock't with Wine, Brandy, and many other Valuable Comoditys. These things are called God's Blessings in this Country. I had one of them last year that brought me in Eight hundred Galls. of French Brandy; another brought me Io hosds. of good Claret, and Froniniack, which your friend Bruce seems to like very well; and 
this very Winter I have had two of these Blessings, one of which brot. me a Noble Stock of Flower, Wine, and Bale Goods, the other brot. me only a parcell of hydes, Logwood, and some other triffles that may be converted into cash. These things are very convenient in a large Family in these hard times, for Corn of all kinds is very dear in this Country at present, and I suppose not much Cheaper in Murray. I would therefore advise you to come and partake of our Cornish Blessings but I shall Referr you to Mr. Bruce for a more lively description of the Country in generall, and this place in particular. Only I must inform you of a good Joke concerning him. The Ship that he is come down to claim was loaded with wine and fruit, for which reason the people of the Country have dubed him with the Tittle of the Figg Man, which seems not a little to touch his Scotch pride; however, as he was an intimate friend of the poor Lyons $^{1}$ and yours, I have showed him all the Civilitys in my power, and hope I shall be able to do him some service in the Affair he is negotiating here. But, when I think on the havock his Ancestors made on the Noble Name of Cumming, I'm almost tempted to deliver up (the cargo ?) to his Antagonists the Wreckers. You'll now be pleased to observe that this is the third letter I have wrote since I recd. one from you; in return to all which I only expect that you'll send me a line or two informing me of your preparing to sett out for Cornwall next month at farthest, that I may have time to

'Brodie of Brodie. 
gett myself ready to meet you at Bath or London - a confirmation of which cannot fail of giving the utmost pleasure to all the friends and Branches of this family, but to none so much as to him who is with great truth and respect, Dear Sir, your most Affect. Nephew, and faithful humble Servt.,

\section{"A Cumming."}

The originals of these characteristic letters are in the possession of Captain Dunbar Dunbar, to whom I am indebted for a copy.

Opposite Penrose are other plantations ; from Degibna Wood, in particular, the view of the lake, Bar, and sea is particularly striking. Here, too, is a natural spring, round which the flowering fern ${ }^{1}$ grows with peculiar grace.

There are some old lead-mines, long since deserted, adjoining the Penrose woods. An adit having communication with one of these has received the name of Duff's Hole, from the following circumstances. About a century ago, two soldiers happened to be passing by the cave, and one of them from curiosity entered, but presently returned in great alarm, saying that there was a man within. Accompanied by his comrade he entered again and discovered a poor man apparently on the point of death, who was subsequently removed to Helston. By careful treatment he was restored, though with the loss of his toes, which were amputated, and it was found 
that his name was Duff, that he was a person of weak intellect, and had escaped from the care of his friends, and had wandered all the way from Scotland till he found the cave in question, into which he entered, with the intention of starving himself. He had been there several days when he was discovered, and had taken no solid food, but, being unable to endure the pangs of thirst,

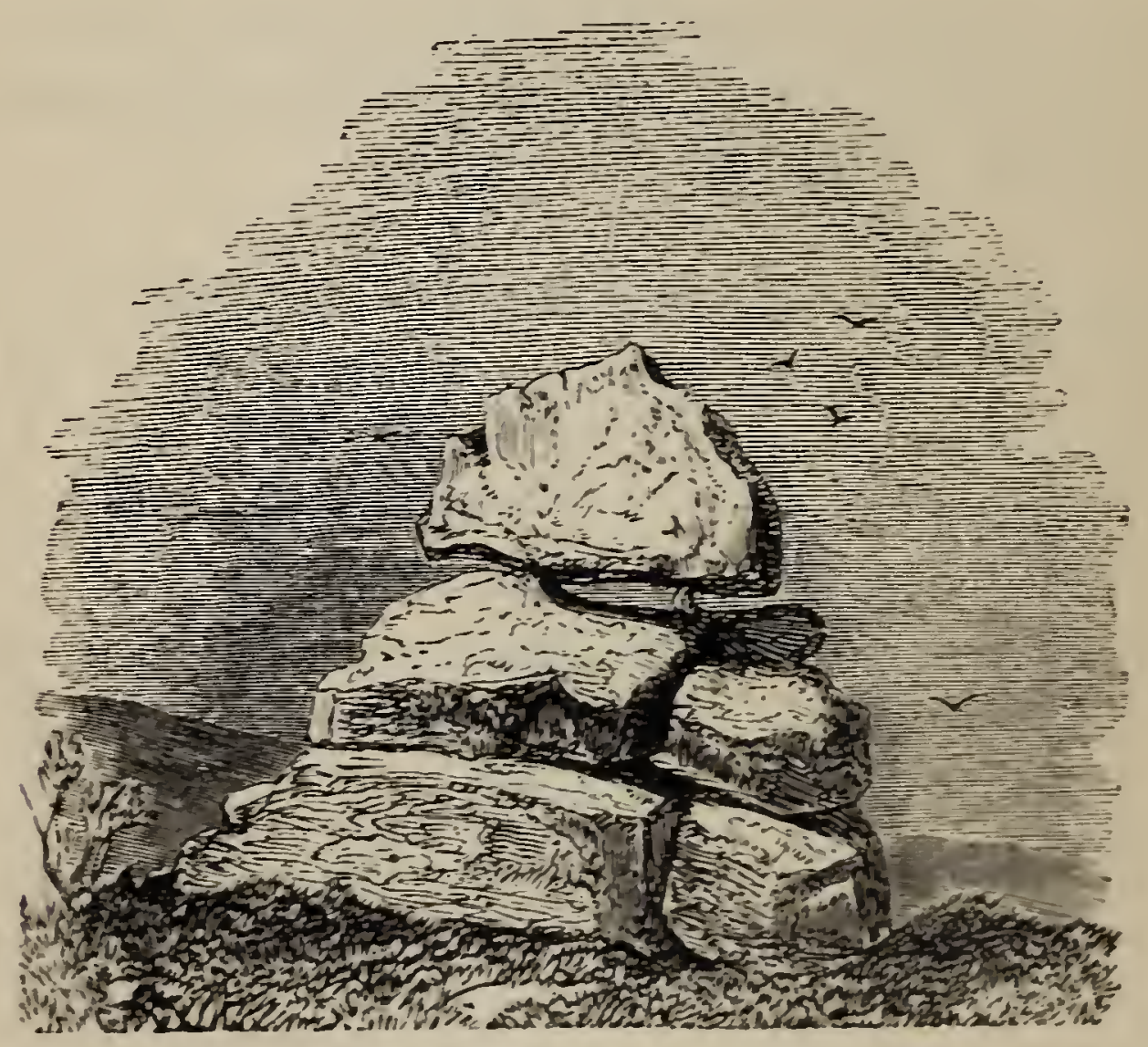

MAINE-A.MBER ROCK.

had, but a short time before he was found, crawled down to the Loe for a draught of water, and had returned to die. His friends were subsequently apprised of his existence, and fetched him home.

There are but few objects of irterest to the antiquary near Helston; the most remarkable is a pile of rocks on Trannick Hill, about three 
miles to the north of the town, and called MaineAmber. Norden gives an engraving of it as it appeared in 1584 , and from this the accompanying woodcut is copied. His description is as follows :- "Maine-amber; Certayne huge stones, so sett and subtillye combined (not by art, as I take it, but by nature) as a childe may move the upper stone, beinge of a huge bignes, with one finger, so equallie balanced it is; and the forces of manie strong men enjoyned can doe no more in moving it." He adds the dimensions of the topmost stone, viz. height, six feet; length, eleven ; thickness, five and a half. It is now no longer a Logan stone; for, in the time of the Commonwealth, it was reported to the authorities that the rock was regarded with superstitious eyes by the lower orders, and accordingly a party of soldiers were marched from Falmouth for the most magnanimous purpose of upsetting it, which feat they duly performed, proving at least that the latter part of Norden's description was incorrect. Its appearance, however, is so little altered, that in turning over the pages of Norden's Survey, I recognised the group before the name caught my eye.

We must not quit Helston without briefly noticing a singular custom which has existed here from time immemorial. Annually, on the 8th of May, a party of men and boys go into the country at a very early hour in the morning, and return about seven o'clock, bearing green branches, and announcing in a very melancholy ditty, that "winter is gone, and that they. have been to the merry green-wood to fetch 
home summer in its place." Having perambulated the town, and accepted money from all who will give, they retire from the scene, and the town, for the remainder of the morning, is enlivened by the frequent arrival of carriages from the country and neighbouring towns, bearing visitors who intend to participate in the coming gaiety.

At one o'clock, a large party of ladies and gentlemen, wearing summer attire, and profusely decorated with flowers, assemble opposite the Town-hall, and, preceded by a band of music, commence a peculiar kind of dance, called "the furry," first tripping on in a double row, and then, at a change in the tune, wheeling round in couples. These evolutions are not confined to the street; for, here and there, where the doors are thrown open, the dancers enter the houses, band and all, traverse the courts and gardens, and may presently be seen emerging by another doorway, if the house be furnished with two, other than that by which they entered. In this way they traverse the whole town, presenting an appearance as gay as it is unusual, especially while winding through some of the exceedingly beautiful gardens for which the town is remarkable, and which at this season, the laburnums and lilacs being in full flower, are arrayed in their most showy livery. Later in the day, other parties go through the same manœuvres, and it is not till late at night that the at other times quiet little town returns to its propriety.

What is the origin of this singular custom is not known. In all probability it is a relic of very 
remote antiquity, and no slight confirmation of this opinion is afforded by the fact, that the air played while the dancing is going on is still traditional in Wales and Brittany, countries to which, as well as to Cornwall, our forefathers retired before their Saxon invaders. 


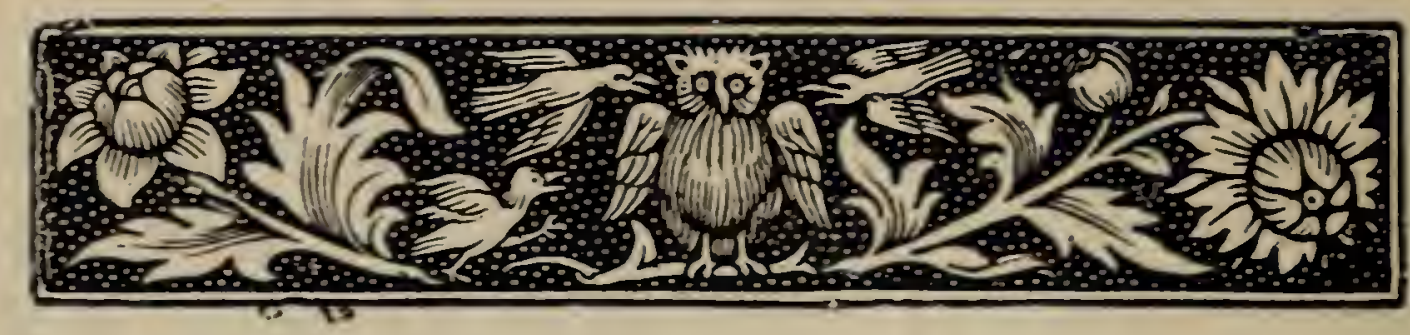

CHAPTER VI.

A Day at Sea-Fishing for Wrasse-Bream-Pleasures of Seafishing - Bathing in Deep-water - Pipe-fish-Minute-fishSwimming-Crabs - Gurnards - Pollack - Cuttle-fish - Dogfish - Daintiness of Crabs - Trammel-net - Spillers and Boulters-Sea-sickness-Crabs, Lobsters, and Craw-fishLoss of Crab-pots-Unexpected Prize-Barter with becalmed Vessels-American and French Barks.

FIVE days of the week have been spent, not altogether unprofitably, I hope, on shore. The sixth, if the weather be favourable, may be devoted to an excursion by sea; and we shall thus have an opportunity of observing the habits of some of the inhabitants of the deep, and of gaining an insight into the daily life of the honest and industrious fishermen of the Lizard.

The history of a day, consisting of fourteen hours, actually spent in a boat belonging to some crabbers, who civilly allowed me to accompany them, and who took great interest in the curiosity I displayed to make myself acquainted with the mysteries of their craft, will answer my purpose better, and, at the same time, be more amusing to my readers, than if I were to present them with an abstract account of the routine operations 
gone through by a whole class. And if I intersperse my narrative with the detail of incidents that occurred on other occasions, I shall be enabled to convey yet further information.

At five o'clock then, on a very bright morning in June, accompanied by a young friend, I met, by appointment, my fellow-voyagers at the Lizard Town, and proceeded with them to Polpeer, where their boat lay, hauled up high and dry, on the sand. The boat's crew consisted of three stout, weather-beaten men, who, if sinew and strength be a criterion, may have derived their descent from the ancient race of Cornish giants. They carried their fishing-lines and provisions for the day; the latter, which they called "foggin," consisting of cakes made of wheaten flour and currants, and a jar of water. This seeminglyunsatisfying fare, they assured me, was their usual food, as they rarely tasted meat. My own sea-stock, I must confess, was somewhat more substantial.

A fewspider-crabs, reserved from the preceding day's fishing, were also stored away in the boat, and we forthwith launched out to sea. We had not gone far when the anchor was thrown over, our hooks were baited with the soft substance obtained from the body of the crab, and the lines let down, the object being to catch fish wherewith to bait the crab-pots. Most of the lines were furnished with leads, which were allowed to sink until the bait nearly touched the bottom; one was thrown over without any weight attached to it, and floated away with the tide. With the latter we almost immediately hooked a 
large pollack, weighing seven or eight pounds, and with the ground-lines were pulled in a good many wrasse, ${ }^{1}$ of various species. The wrasse, or ra-agh, as the fishermen pronounce it, is a thick, heavy fish, with fleshy lips, and mottled with red, yellow, and green. One species, less common than those which we caught to-day, but still not rare, has a prominent eye, and when taken from the water is variegated with the most brilliant colours that I have ever seen, azure-blue, orange, and yellow being the predominant tints. It is called by the fishermen a cuckoo, and is probably the "striped wrasse" 2 of authors. None of the species are valued as food; the cuckoo, particularly (for I have had the curiosity to taste it), is watery and insipid. But neither crabs nor lobsters are fastidious, so my companions were well satisfied with their capture.

In a short time the tide ceased to be favourable for fishing in this spot; we accordingly weighed anchor, and rowed off to try for some bream, at a greater distance from shore, in a place selected by the fishermen outside the Stags. Here we again cast anchor, and fished with our lines near the bottom in much deeper water; our bait being still the soft part of a spider-crab tied to the hook by fine twine, to prevent its being washed off by the tide. A light line was also thrown over, with a larger bait for pollack.

It not unfrequently happens that one may sit for an hour or two at this kind of fishing without

1 I.abrus.

2. variegalus. 
getting a solitary bite; yet, for all that, there is always something pleasing to look at, and something happening calculated to amuse and instruct. In the first place, the mere fact of being buoyed up in from ten to twenty fathoms of clear blue water, gently rising and falling with an agreeable motion (though some, perhaps, may question this), produces a pleasurable and tranquil state of mind.

Then there is in the hottest weather (and such should always be chosen by the amateur) a coolness in the air not to be obtained on the shore. More than half of the horizon is open sea, and the line of coast is exquisitely beautiful under all circumstances. The pulling up of the line occasionally to see whether the bait has been nibbled off, is certainly rather tame work; but the hook may catch fast in the bottom, and then one has a very good chance of bringing up some quaint zoophyte or brilliantly-coloured sea-weed; and there is always an interest connected with specimens thus obtained, which does not attach to those thrown on shore after a storm. Sea-birds of various kinds every now and then fly past the boat, about which the boatmen generally have something to say.

If one be a swimmer, there is something particularly delicious in plunging in and paddling about in water, cold, pure, sparkling, buoyant, and in every way as superior to the water which washes the shore, as that is to the muddy fluid brought down by an inland river; no decaying sea-weed, no bruising of knees against sunken rocks, no cutting one's feet by stepping on 
broken bottles. Then, if one could but forego the necessity of breathing, and drop down some hundred feet, what rare specimens in natural history might be discovered - what insight gained into the economy and habits of creatures of whom we now know nothing but their shape, colour, and the number of their fins! It seems strange to have beneath one, and yet to be unable to visit, a region as unexplored as the centre of Africa. To be sure when one has had enough of swimming, it is not quite so easy to get into the boat as it was to jump off; and, though no danger is. to be apprehended from sharks, one runs the risk of encountering a shoal of snorting porpoises, immediate contact with whom would not be altogether pleasant, though they are not mischievous; but these inconveniences are more than counterbalanced by the positive enjoyment of the thing, and need deter no swimmer from the attempt; learners had better practise near home.

But without actually going into the water we shall not find the time hang heavily. The fishermen are always ready to communicate what they know of the inhabitants of the deep, and some of the latter occasionally come to the surface and tell their own tales. One of these is the snake pipe-fish, a singular little animal, seven or eight inches long, so unfishlike in shape that I thought at first that it was a fragment of a slender sea-weed. It crawls along the surface of the water with the motion of a serpent, and may readily be taken with the hand. Nothing appears to be known of the habits of this par- 
ticular species; but the "great pipe-fish" 1 is remarkable for the attachment which it displays for its young. It is furnished underneath with a pouch, which serves as a shelter to which the young ones retreat in case of danger. M. Risso states that, when an adult fish is taken, if the young be shaken out of the pouch into the water,

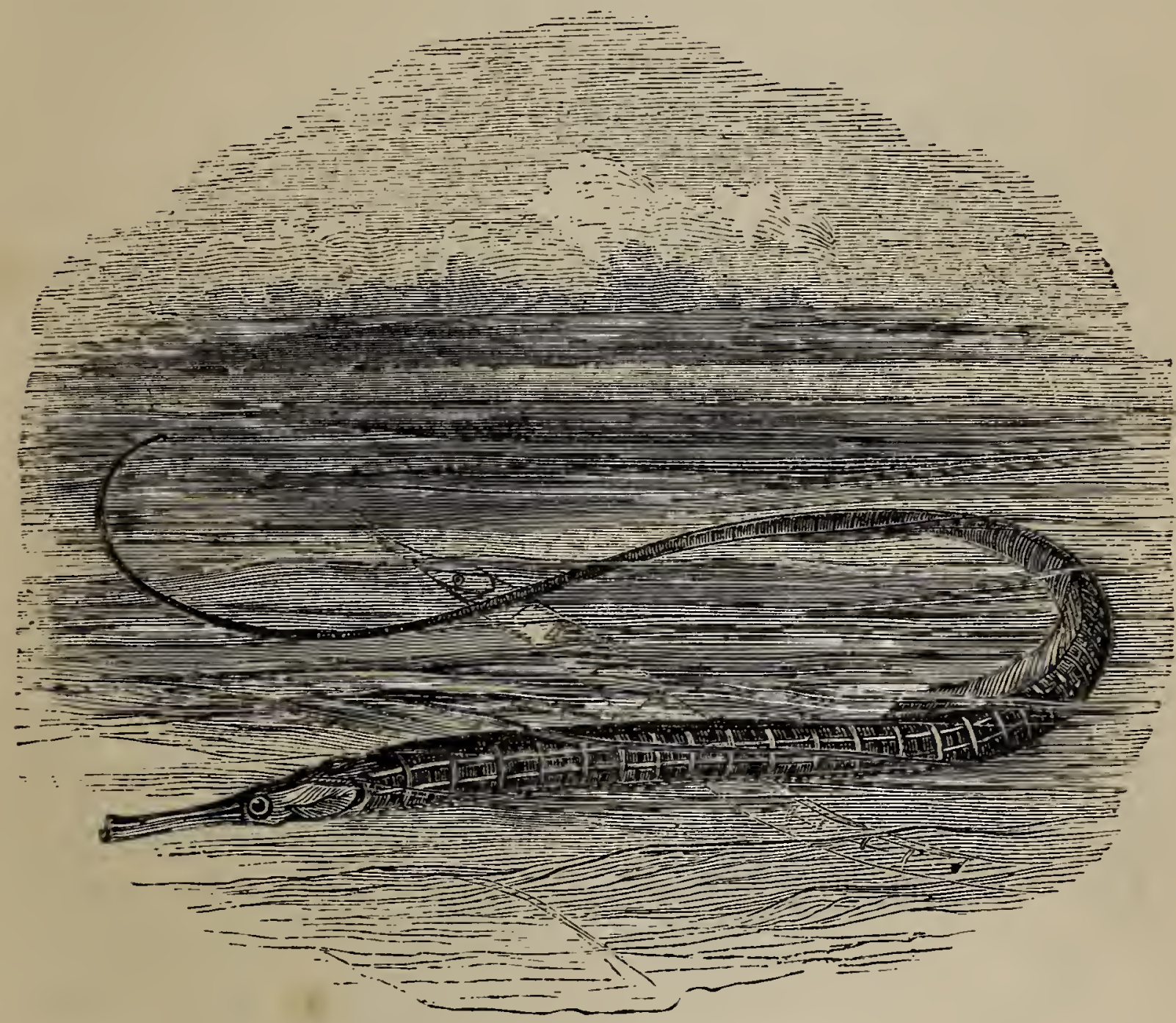

SNAKE PIPE-FISH.

they will not swim away, but when the parent fish is held in the water in a favourable position, the young will again enter the pouch.

Sometimes a merry little company of about half a dozen minute fishes, less than an inch in 
length, swims up to the boat, as if to inquire, "What is going on here?" They are evidently in no hurry, and are quite disposed to be on familiar terms, except that they prefer remaining in their own element. They swim with a vibratory motion on the surface of the water, keeping very close together until you attempt to catch them; but touch the water with but the tip of your finger and they instantaneously disperse, and as quick as thought re-appear, just beyond your reach, in a party as compact as ever. They are too insignificant to have received a name from the fishermen, nor am I aware that any naturalist has described them. I have never had the opportunity of inspecting them closely.

Small swimming crabs, while engaged in their foraging expeditions, occasionally come near the

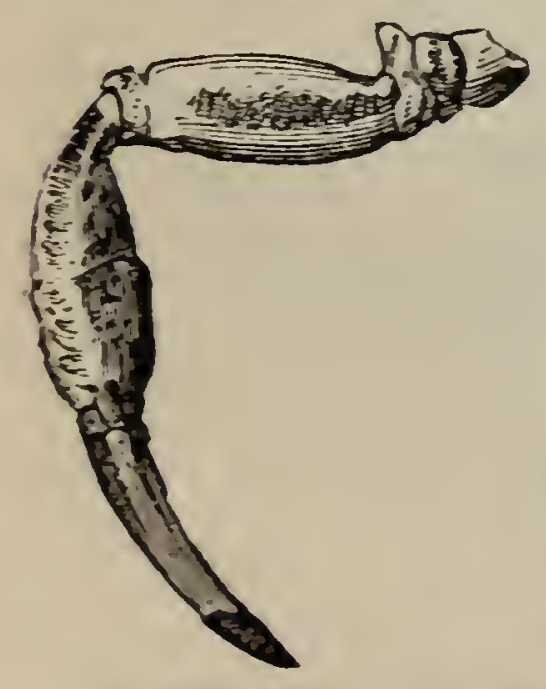
SWIMMING-CRAB.
HIND-LEGS OF WALKING AND

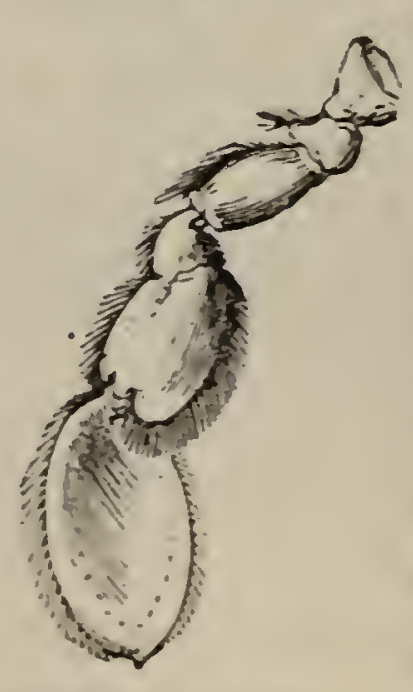

boat. They differ in structure from the other crabs in having their legs flattened instead of round ; one pair especially is dilated to a remarkable degree, and with these they paddle themselves along very cleverly, keeping close to the surface of the water. Their food consists of the light particles of animal matter, which have either risen from below, or been dropped by seabirds. They are, too, quite active enough to hunt for and capture living fish, such as the 
pipe-fish described above. One of these crabs, ${ }^{1}$ which I caught by throwing it a baited hook and drawing it towards me until I could reach it with my hand, I once carried home in my pocket to examine at my leisure. Next day I expected to find it dead, but, on taking it out, I discovered that it was as active and lively as when I first caught it. This tenacity of life is essential to the habit it possesses of searching for its food, not only at sea but among the sea-weed thrown upon shore. Being desirous of watching the movement of its swimming legs, while it was floating in its own element, I placed it in a glass of fresh water; upon which, without making the least struggle or moving a joint in its body, it sunk instantaneously to the bottom, quite dead. Thus, fresh water may be more speedily fatal to a marine animal that spends the greater part of its life in salt water, then immersion in water of either kind is to any animal living in the air.

It is a singular coincidence, that many species of sea-weed, especially the Griffithsias, which will bear exposure to the air for a considerable time without undergoing any change, immediately that they are placed in fresh water discharge their colouring-matter with great rapidity, tinging the water in the course of a few seconds. One species in particular, Griffithsia secundiflora, which is remarkable for the large size of its cells, discharges nearly the whole of the red fluid which they contain with such force when it is

1 Polybius Henslowii. 
thus treated, that it has been known to send a jet into the eye of the collector, causing considerable pain and annoyance.

Sometimes the boat is suddenly surrounded by a shoal of mackerel or pilchards rising to the surface with a noise resembling. that which accompanies the throwing of a handful of gravel into a pond. On these occasions the mackerel rarely take the bait ; the pilchard is never caught with a hook, though it makes an excellent bait for other fish, and on this account its appearance is frequently followed by good luck to the fishermen.

The fish usually caught by boats anchored within a mile or two of the shore are bream, chads, or young bream, gurnards, pipers, pollack, whiting, pouting, flat-fish, dores, with perhaps two or three congers and skates, for which last a stout line is thrown over, furnished with a large bait, which is suffered to remain at the bottom. Gurnards and pipers are remarkable for making a peculiar grunting sound when taken out of the water, whence the latter derive their name, and indeed, perhaps the former by some fancied similarity between the sound and the name. The noise does not appear to be indicative of pain, but to result from the transmission of an unusual fluid through some narrow passage. It is probable that the pain occasioned by the fastening of the hook in the cartilaginous mouths of fishes is very slight, if any; for it is a very common occurrence for a fish, which has swallowed a hook, immediately to catch at, and be hooked by, another, so that the fish comes to the surface with two hooks in its mouth at once. 
Gurnards, bream, and chads usually feed in company, and, as they are very ravenous, are often caught in large numbers to the exclusion of almost every other fish. The larger pollack swim about singly, keeping much nearer to the surface of the water. They are fished for with a light line, which is suffered to float away with the tide. A good bait is a sand-launce or a piece of pilchard, but if chads are around the boat the only bait which escapes being carried off by those voracious little fish is a piece of one of themselves.

The pollack-bait is not unfrequently attacked by cuttle-fish, which fasten on it with their long arms and greedily devour it with their parrot-like beaks. Their interference is detected by a repeated jerk at the line, followed by a steady pull. As they never swallow the hook, the fishermen make prize of them by drawing in the line very gently, until the bait, with the hungry monster attached, comes close to the boat, when a light stick, the end of which is armed with a stout hook, is passed under it, and the animal is secured. It immediately discharges a jet of black fluid, which discolours the water for some feet round; it may then be lifted into the boat, but still not without caution, as it frequently collects its strength for a fresh discharge, and I have seen it blacken the face of the person who caught it as well as bespatter myself and another from head to foot, though we were sitting at some distance. The cuttle-fish is never eaten in Cornwall, but is much used as bait, particularly for congers, fish which, untempting as they look, here command a readier sale than many other elsewhere considered delicacies. 
Pollack are often attracted round the boat by what the fishermen call "smear," that is, offal of fish and bilge-water, which they occasionally throw overboard. Sometimes the sport is entirely put a stop to by a swarm of dog-fishes. These ravenous creatures attack the bait whether moving or at rest, in deep water or near the surface, and effectually drive away every other fish less powerful than themselves. I one day fished in five or six different spots usually frequented by some one or other of the kinds named above; but no -there were "dogs," as they are called, everywhere, and in abundance, but nothing else.

It matters not much to the crabbers what sort of fish they catch, provided they have enough to supply all their crab-pots with fresh bait. Crabs are not, as they are sometimes supposed to be, the unscrupulous scavengers of the deep, revelling in decomposed animal substance, and preferring that which is most corrupt. On the contrary, they will condescend to touch no bait unless it be perfectly sweet and untainted. When bait is scarce, the fishermen will sometimes use salted fish-ling, or cod-but it must be well cured, or no crab will come near it. This daintiness of the $\mathrm{crab}$ renders the life of the fishermen much more laborious than it would otherwise be, inasmuch as they are obliged, before they haul the crabpots, to lay in a stock of fresh fish, which they must either catch the same morning, or, if caught over night, must thoroughly cleanse before it has acquired the least taint.

It requires no little attention and trouble to furnish themselves beforehand with as much as 
they require, especially in the early part of the season, when crabs are most numerous, and fish, for the most part, at a distance from land. They depend for this supply on line fishing, the trammel net, and boulters or spillers. The trammel is a long net, about five feet deep, with a double mesh, one large enough to allow the fish to pass through, the other much smaller. The net is sunk to the bottom of the sea by means of an anchor at each end and a row of leads along the lower edge, the upper edge being buoyed up by a series of corks, but without reaching the surface. It is laid in the evening and examined in the morning, and vice versâ, when the fish are found entangled between the large and small meshes. One end of a stout rope is made fast to each anchor, the other end being attached to a string of large corks to mark the position of the net. The fish caught in this are generally dead before they are taken in, ${ }^{1}$ and are very frequently partially eaten by crabs, which often become entangled themselves, and are caught together with their prey. Spillers and boulters are long stout lines, to which are attached several hundred baited hooks, with an anchor and waste-line furnished with corks at the end. These are set at the bottom of the sea in the evening and examined next morning. The preparation, baiting, setting, and hauling of these are works of time and labour of themselves, but, after all, mere preliminaries to the principal occupation, crabbing, as it is popularly called.

1 The red mullet always are, the pollack generally so, bu
the wrasse never. 
From this digression let us return to our boat, which we left at anchor off the Stags, waiting till the fish beneath should be ready for their morning meal.

We remained here as long as the tide was favourable for our occupation, which was until the current became so strong that our leads would not touch the bottom. During this time we had caught about two dozen large bream, which, with what we had secured before, the boatmen considered to be enough to furnish all their crab-pots. Long before this, the motion of the boat had proved too much for my young friend, who, pale and wretched, was lying against the sicle of the boat, with his head resting on the gunwale, and indifferent whether he pulled in fish or fish pulled him out. One of the fishermen endeavoured to comfort him by assuring him that the complaint was especially beneficial to the health, and that he himself, though he had been accustomed to a boat all his life, never went to sea, after a day's cessation, without suffering more or less. On the preceding Monday, he said, he had not gone to sea, nor, of course, on the day before. The consequence was, that Tuesday was to him a day of utter misery. I did not, however, perceive that this piece of information had any effect in reconciling my companion to the tidings, "that there was no chance of his being landed in less than two or three hours."

Having weighed anchor, we proceeded landward, the helmsman steering by well-remembered marks for the place where was laid his first string of eight pots, that being the usual number set 
together. The construction of the crab-pot is too well known to require description; what I particularly noticed was, that the ropes by which the floating corks are attached to the pots were thickly invested with fine seaweed; in a fortnight, we were told, a new rope became thoroughly coated. The men having taken out from the

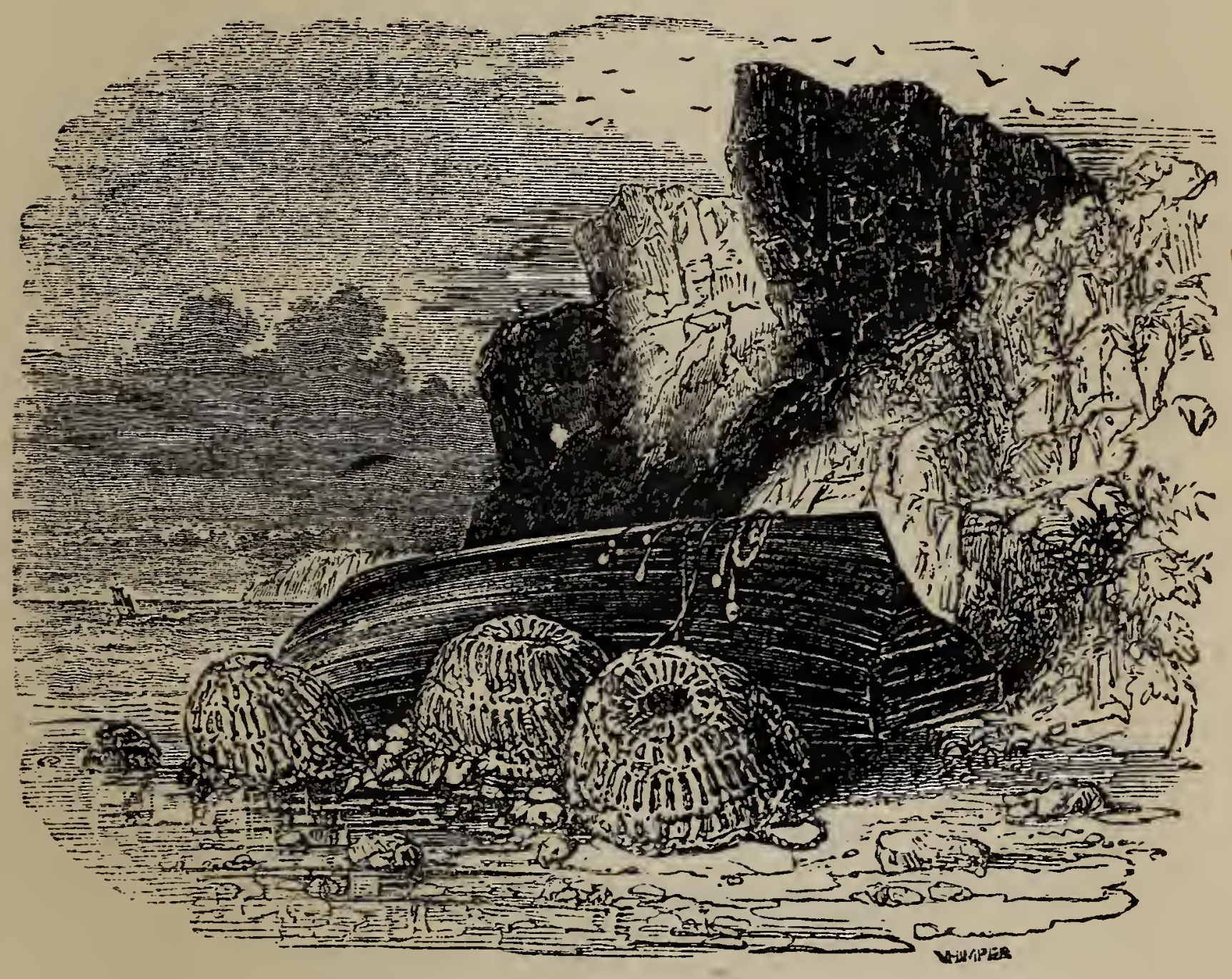

CRAB-POTS.

pots the crabs, spider-crabs, craw-fish, and lobsters which were caught, suffered them to creep into the locker of their boat; they then threw away what remained of stale bait, and supplied the place with what we had just caught. The string was then conveyed to another spot and thrown overboard, so as to form as nearly as possible a 
line. This process was repeated as often as we reached a new string, occasionally varied by the hauling of a large pot baited with fragments of spider-crabs, in which were caught a few poutings, conger, and wrasse.

During the spring months, I was told, crabs are more numerous than any other crustaceous animals; as the season advances, lobsters are also caught in considerable numbers; late in the summer, crabs "leave off walking," and retire to holes in the rocks, and their place is supplied by crawfish, which abound until the end of the season. Lobsters and craw-fish of a large size are occasionally caught with the lines baited with fish, which are set for congers, \&c. They do not, in this case, actually swallow the hook, but become entangled by their claws and horns in the line. These animals have a twofold power of motion, one by crawling with their legs, the other by repeatedly flapping their tails against the under side of their bodies, and forcibly expelling the water; the motion produced by this last operation is backward, but very rapid. Dr. Borlase relates the following marvellous anecdote of instinct displayed by a Cornish lobster: "As he was fishing one day, a fisherman observed a lobster attempt an oyster several times, but as soon as the lobster approached, the oyster shut his shell: at length the lobster, having waited with great attention till the oyster opened again, made a shift to throw a stone between the gaping shells, sprung upon its prey, and devoured it."

When we reached Kynance Cove, there being little surf, we were enabled to land our invalid, 
and it was surprising to watch with what alacrity he sprang up the rocks as soon as the power of regulating his movements was transferred from the sea to himself. We soon lost sight of him, and again put out to sea.

From Kynance we crept along close to the cliffs, passing the Rill, and stopping at intervals, to secure the spoil, till we reached the Horsepond, where lay the last string of pots set near the shore. The scenery all the way is exceedingly grand, arid, as we advanced, varied as much at sea as on land. Familiarity with the scene had not dulled the appreciation of the beautiful, even in the fishermen; for they frequently directed my attention to the more remarkable points of view.

Stretching off to sea about two miles, we reached the ground where the deep pots were set; these were hauled, examined, and reset, like the first. While we were engaged on one of these strings, a merchant-vessel slowly bore down upon us, the helmsman of which, at the earnest request of our men, slightly altered his course to avoid passing over the pots, there being great liability that the corks might catch in the rudder, and thus that the pots themselves might be dragged along bodily and be lost. Occurrences of this kind are purely accidental, for the helmsman cannot be expected to keep a look-out for objects so small as the corks which mark the position of the pots; but the fishermen told me that in calm weather they suffer much from depredations on their capture committed by dishonest sailors, who frequently launch their boats, haul the pots, and 
appropriate the contents to their own use. The fishermen sometimes see the reward of their toil and enterprise thus carried away under their very eyes, and are obliged to submit ; for as they are ignorant of the name and destination of the vessels, they have no means of obtaining redress.

After we had completed the proper business of the day, the men proposed, if I had no objection, to board a large vessel, which lay becalmed about two leagues off, for the purpose of exchanging some of their fish for bread. To this I readily consented, for, in the first place, being a visitor, I had no right to prevent their seeking the best market they could find for their goods, and secondly, I was most desirous of getting a. thorough insight into their mode of life ; moreover, the boarding of foreign vessels had in it something of novelty and an air of adventure: Accordingly the boat's head was put about, and we rowed off in the direction of the Land's End.

On our way we fell in with an enormous ling, which lay floating with its body partly out of the water. The men at first supposed that it was alive, and approached cautiously, prepared to capture it with a gaff, a large hook attached to a stout stick. It proved, however, to be dead, though quite fresh : it was infested by large numbers of marine insects, which perhaps might have killed it. It was joyfully lifted on board, for, as it weighed upwards of forty pounds, it contained nearly enough bait for the next day's fishing.

When we reached the vessel, the end of a rope was thrown to us, which we made fast, and so kept alongside while the bargain was being struck. 
She was an American bark, and had been out so long that her crew were on short allowance of bread. Salt-beef, however, was on board in great abundance. Three times a bucket was let down full of this, and three times hauled up, filled with spider-crabs, the wary fishermen concealing their lobsters and best crabs, for which they had a sale at home, and producing those only which, though said to be of a superior flavour, have no value in the English market. I was at first inclined to consider this manœuvre somewhat dishonourable; but on second thoughts I could not see that any unfairness was committed. The crabs which my companions proposed to exchange were fresh and wholesome, though uninviting in appearance, and the Americans, having their eyes open, might accept the bargain or not, as they pleased. The transaction would have been a dishonest one if the article exposed had worn a fair exterior but been unfit for food. True, the crabs and lobsters which the fishermen reserved in their locker were superior, but they were not called on to sell them unless they liked, any more than the other party were required, against their will, to part with the more valuable commodity, bread. I was consequently, on the whole, much amused at witnessing the barter.

Having cast off the rope, we proceeded to board another bark, which lay about two leagues further to the west, the men being very desirous of procuring bread, which, at this particular period, was scarce and dear. This distance, like the last, was performed by rowing; so that as, in both cases, the crew of the boat had all the 
labour to perform, they were scarcely unreasonable in expecting to make the best of the bargain. It was not a usual thing, they told me, to board vessels in this way, for when the brceze is stirring, the vessels move too rapidly to be overtaken. To-day the weather was so calm that the ships, with every stitch of canvas spread, did not move so quickly through the water as the heavy boat, impelled by a single pair of oars. Most frequently, by the time the fishermen have hauled all their crab-pots, they are glad enough to return home, weary, and soaked through with the sea beating into their boat. But wet from saltwater they do not at all heed, for they say that it never does them any harm. If, however, it comes on to rain before they have accomplished their work, they make all speed to regain the shore; for, hardy as they are, if wetted with rain-water they run a great risk of being laid up with colds and rheumatism. It is, then, only in the finest summer weather, when sea and air are both calm, that they reap any harvest in this way; nor are they to blame if they honestly make the most of it.

The next vessel turned out to be a Frenchman; and as no one of her crew could speak English, and, as might be expected, no one of the fishermen knew a word of French, the scene which ensued was not a little amusing.

The light-hearted Frenchmen were much diverted at the quaint look of the spider-crabs, and vociferated most eagerly their desire to have some; but what principally attracted them was the great ling which lay in the bottom of the 
boat. In vain the fishermen declared that ther had found it dead, and that it was consequently unfit for use; "le grand poisson," the large fish, was in every one's mouth. Still the fishermen persisted in holding up spider-crabs alone, and demanding bread. For a long while I sat still, too much amused at the good-humoured altercation to put an end to it by acting as interpreter. At length, to the great surprise of my simplehearted boat's company, who, I believe, thenceforth thought me a prodigy of learning, I explained to the captain what we wanted. I now became a person of importance. The vessel, I found, was homeward-bound, and under short allowance of bread; so, at least, said the captain; consequently he had none to spare. The fishermen then asked for brandy, a bottle of which was soon produced, and some crabs were handed up the side of the vessel to the crew, who took them one by one, holding them by the extremity of a claw with ludicrous caution. As they were deposited on the deck, a knot of sailors gathered round them and examined them, laughing immoderately. I explained to the captain that the grand poisson was only fit for bait: but could perceive very clearly that he did not altogether believe me; however, he ordered a tumbler of wine to be handed down to each of us, which my companions drank with wry faces, but which to me, who was beginning to be exhausted with the heat, was very grateful, on account of its lightness and acidity. He offered also to fill another bottle with wine, in exchange for some more crabs. While this bargain was being conducted, 
he happened to spy a craw-fish, which was only partially concealed by the crabs, and, with an earnestness worthy of a better object, implored me to let him have it for his own dinner. But this the men refused parting with unless he paid a shilling for it. I then explained to him that the men could sell craw-fish at home for more money than the wine or brandy was worth to them, but that they were willing to sell him one for a shilling. In reply, he with great vehemence assured me that all the money he had on board was half a franc-piece (fivepence), which he produced. Upon this, thinking that I ought to make some return for my glass of wine, I promised the men that I would settle with them, and told the captain that I would make him a present of the difference between the sum which he offered and that which they asked. Nothing could now exceed his delight; he took off his hat to me, and gave me the most ample assurance that if ever I came to his country I should find that he was not ungrateful. Accordingly, the craw-fish was handed up and received most enthusiastically, and we, having first wished our excitable friends a prosperous termination to their voyage, parted company, and proceeded homeward.

We had not long quitted the vessel when we observed in the offing a flock of gulls, collected round what the fishermen conjectured to be a log of wood infested with barnacles. Many logs in this condition had recently been picked up at sea, or washed ashore, which, although they had been claimed by the Admiralty, were afterwards given up to the finders, as sron as it was 
reported that the timberwas injured. Gate-posts, barn-doors, and such things, are, in the Lizard district, often made of timber recovered in this way: they may sometimes also be seen completely eaten out by the teredo. Our boat's company were now, however, pretty well tired of their

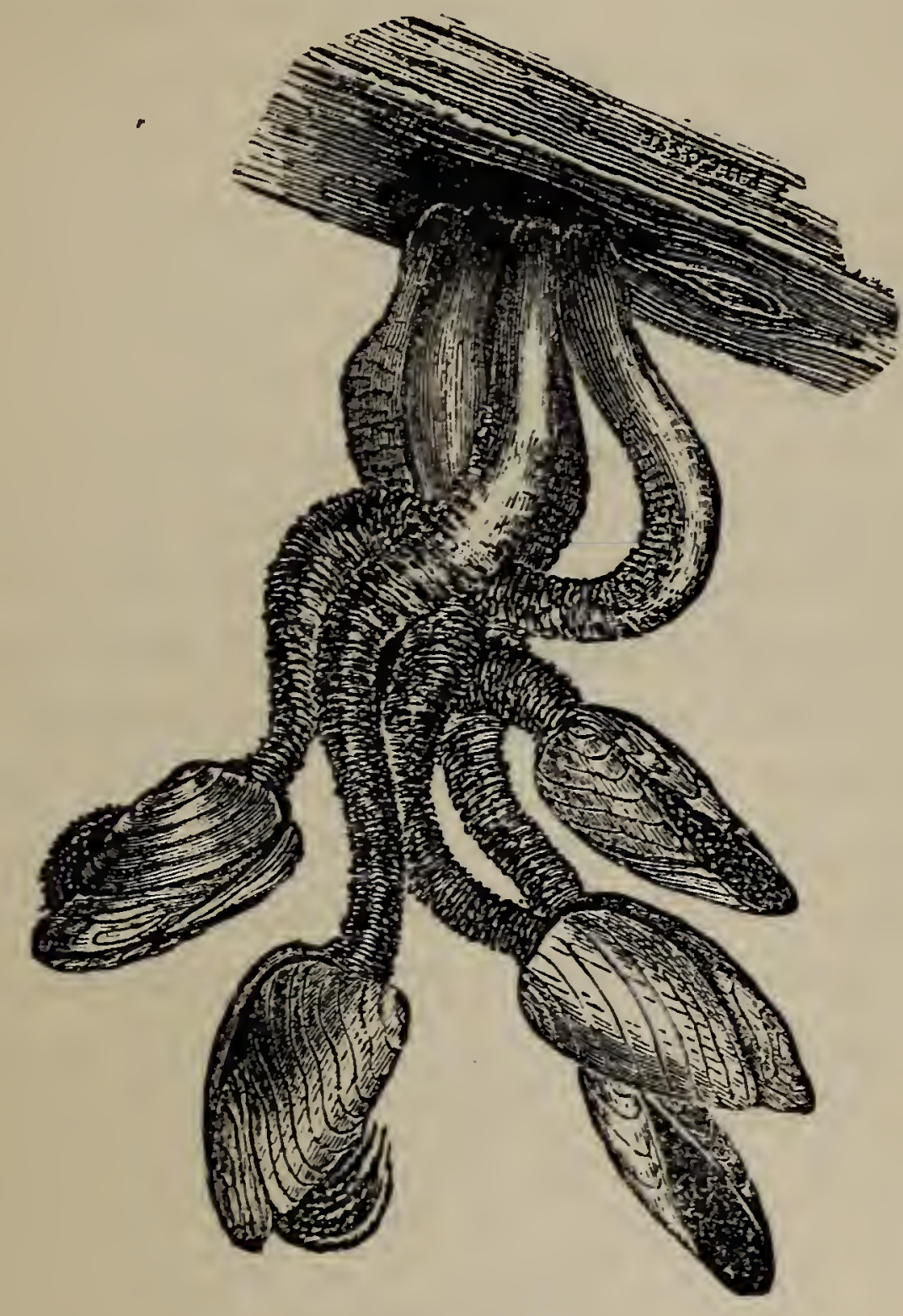

BARNACLES.

thirteen hours' hard labour (for the sail had been of no use to us all the way); we therefore left the timber to its fate, and pursued our course till we arrived at the spot where the "store-pot" was sunk. This name is given by the fishermen to a crab-pot of much larger dimensions than 
ordinary, which is kept in a sheltered place, at the bottom of the sea, and in which are stored up every evening the crabs and lobsters caught during the day. We were delayed a few minutes to perform this operation, the crabs being first prevented from injuring one another during their confinement by the insertion of the point of a knife into the joint of the great claws, which separates the membrane connecting the two pieces, and renders the nippers powerless. A vessel calls off the fishing-coves once a fortnight, when the store-pot is emptied and its contents transferred to a well in the hold of the vessel, where they remain alive for many days. This process of piercing the claw is perhaps not so cruel as it appears to be, for, from the fact that many of the crustaceous animals have the power of throwing ofi an injured limb, seemingly without suffering any inconvenience, we may infer that the part in question is not very sensitive of pain. At seven o'clock we found ourselves safely on shore at Polpeer, the cove from which we had started in the morning. 


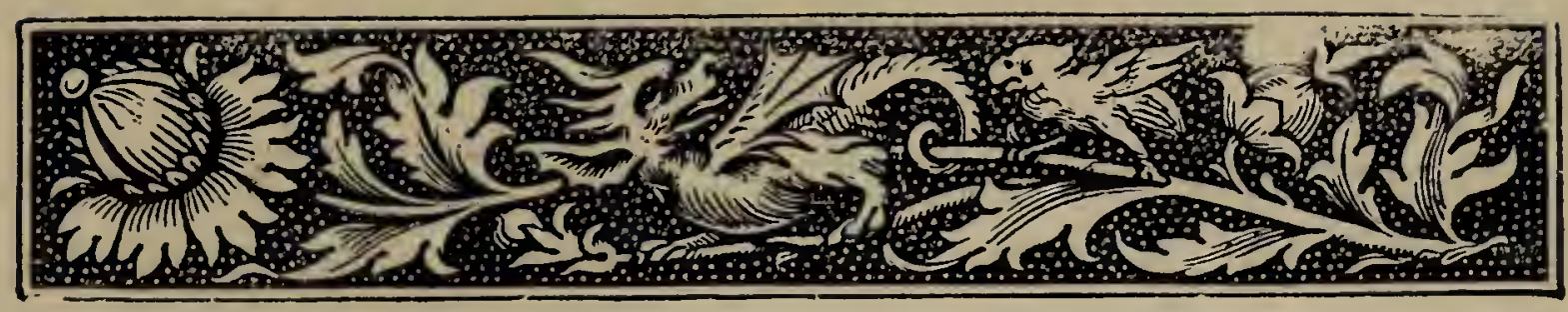

\section{APPENDIX I.}

Geological features of the Coast-Granite-Killas-Greenstone - Serpentine-Mica Slate-Diallage Rock-Botany of the District-Loe Pool-Gunwalloe-Mullion-Kynance-Caerthillian-Cadgwith-Poltesco-Kennack.

IN the hope that some few of my readers at least may one day have an opportunity of exploring the beautiful line of coast which I have used my humble effort to describe in the preceding pages, and that they may, in this case, take an interest in the geology, botany, and ornithology of the district, I have devoted the few pages that remain to the special consideration of these subjects. I do not intend to do more than direct their attention to the objects of particular interest which are likely to fall in their way, referring them for detailed descriptions to works exclusively devoted to the sciences in question.

The high land west of Helston, comprising Tregonning and Godolphin Hills, is composed of granite, the felspar of which is in some places decomposed, and the soft stone is quarried and used in the manufacture of china. At Trewavas Head the granite dips to the sea, and a little to the east joins the clay-slate formation, popu- 
larly known by the name of Killas. The face of the cliff is here well worthy of examination, the two rocks running into one another, and affording a singular contrast of colour, which is observable from the sea for some distance. The killas continues eastward, occasionally traversed by veins of quartz and masses of trappean rock, nearly to Mullion. Here it assumes the character of greenstone, a basaltic rock of fine granular structure composed of hornblende and felspar. It is very hard, strikes fire with steel, and emits a strong smell when struck by the hammer.

Ascending the hill south of Mullion, we first fall in with the serpentine formation. This rock derives its name from the variety of the colours which it presents, and partly perhaps from its scaly appearance, where a smooth slab is exposed to the air. It is considered by some seologists to be of volcanic origin. The predominant colours of the serpentine of this district are dark green and reddish brown; but the choicest varieties contain almost every colour that can be named. It is frequently studded with spangled crystals of diallage, a mineral of almost the same component part as the serpentine itself, but easily distinguished by its laminar structure and metallic lustre, varying from grey to bronze colour. Lodes of steatite or soapstone and calcareous spar are not uncommon in the serpentine, the former often of a considerable size, and containing ores of copper and strings of the native metal. Veins of granite may also be observed at Kynance and near the Balk. Most 
of the caves on the coast appear to owe their origin to the wearing away of the softer mineral by the action of the air and water. The use of serpentine for the manufacture of works of art is beccming more general, and in fact, for such purposes as making ornamental vases, small pillars, chimney-pieces, \&c., no more beautiful material can well be imagined. It is also exported for the manufacture of carbonate of magnesia and Epsom salts, magnesia entering largely into the composition of serpentine and most of the minerals which occur in it. As we draw near Pradanack Head we readily discover, from the piled appearance of the rocks, that we have quitted the serpentine and reached another bed of greenstone, like the first. It soon terminates, and serpentine reappears and reaches to Caerthillian, where a castellated pile of lichen-clad rocks assures us that the basaltic formation once more predominates. This mass stretches across to Pen Olver and the Hot Points, passing in certain places into hornblende slate, which, whereever it has undergone decomposition, is remarkable for its fertility. The Lizard Head and the rock to a limited extent on either side of it are composed of mica, or talcose slate, there being some diversity of opinion among geologists to which class it should be referred.

The trappean or basaltic rock, composed of hornblende and felspar, reappears near Polpeer, and extends to the Lizard Cove, where we again encounter serpentine, some of the finest varieties. of which occurred at the Balk and under Cadg. with Signal-staff. Beautiful as these are, they 
were for a long time unavailable for ornamental purposes, owing to their tendency to split into small pieces; but the rock having been lately quarried to a considerable depth, compact blocks of large dimensions are now obtained. The handsome vases, candelabra, and other ornaments sent to the Exhibitions of I85I and I 862 were manufactured from blocks of stone procured at Poltesco Cove, near Ruan Minor, by the Lizard Serpentine Company. ${ }^{1}$

Beyond the Blackhead an immense bed of rock occurs, popularly known by the name of Crousa stone, from Crousa Downs, where it abounds. It is known to geologists by the name of diallage rock, from its containing large crystals of this mineral, intermixed with hornblende and felspar; the latter being frequently tinged with red. It is a very handsome stone, and if it were situated conveniently for shipping, would probably be used to a great extent. A small mass of it occurs half-way between Kennack and the Blackhead.2

The strip of land which constitutes the county of Cornwall being narrow and almost insulated, no part of it is very distant from the sea; consequently it may be said to be almost all seacoast. The prevailing wind ranges from southwest to north-west, and having to traverse a wide extent of ocean, is so thoroughly charged with

1 The Company have erected a large factory at Poltesco Cove, under the management of Mr. Symons, and specimens may be seen at the works.

${ }^{2}$ For a more detailed sketch of the geology of the district, see Appendix III. 
moisture before it reaches the Cornish shores, that even in the most central tracts of the country the climate is damp.

It is a well-known fact, that wind which has set across an extensive plane surface, either of land or water, exercises a pernicious effect on vegetation, until it has been broken by passing through some resisting medium, such as a quickset hedge or belt of trees. Hence in the exposed parts of the county, that is to say on both the coasts, forest-trees will not thrive unless artificially protected. Both the blighting effects of the wind and the humid character of the atmosphere are strongly evinced by the character of the vegetation in the district which we now have under consideration. On the high ground, either there are no trees, or if here and there a few have been carefully nursed behind a screening bank, as soon as they begin to raise their branches above their shelter, the leaves on the windward side are scorched and shrivelled up almost before they have attained their full size ; the twigs on the leeward side alone mature their wood, and, as a matter of course, on this side only branches are developed; the tree becomes irregular in shape to such a degree that the leading shoot, with a few straggling comrades on either side of it, stretches out like the arm of a directing post, at right angles with the bole. All, indeed, do not yield to the blast in an equal degree, but it is very difficult to distinguish a tree by its sprays without a very accurate examination. On the other hand, the valleys produce trees of respectable size; but the leaves 
wither early in the season, and for the most part shrivel and turn brown without acquiring the true autumnal tint of the species, and the branches. are quite bare some weeks before the trees in the midland counties have begun to discard their party-coloured liveries. Ferns, however, which delight in a moist atmosphere, here luxuriate; every valley and sheltered lane is filled with them, and surpassing as they are in grace and elegance, they quite atone for the deficiency of more elevated foliage.

Between Penrose and the Loe Bar is an ancient oak-wood, not containing the lofty spreading trees which the name would lead us to expect, but one-sided straggling trees, rounded off on the windward side as if trimmed by the forester's shears, and on the other stretching out their long crooked arms almost parallel with the sloping sides of the hill. Within these, and protected by them, the trees assume more of the true character of the oak, but are destitute of domelike heads. The exterior surface of each may be not unaptly compared to a plate in the shell of a tortoise, so skilfully have they adapted themselves to the circumstances in which they are placed.

Within the last fifty years a great change has been effected in this locality by the judicious planting of screens, composed of such trees as have been found most capable of resisting the sea-air, and by introducing with them a variety of other timber-trees, which have materially improved the character of the woods. In one of these plantations is a thorn-tree, 
which is well worthy of notice, as conveying at a single glance all the information contained in the preceding remarks. Some years since it was an old weather-beaten stump, with a few ragged arms stretched out horizontally, as if bending before a perpetual storm. But a belt of hardier trees has grown up between it and the Loe Pool ; and from the gnarled and seemingly lifeless trunk of the thorn there have sprung up several stout and healthy shoots, covered with smooth bark, and producing foliage and blossom that would vie with the fairest May-boughs in the land.

Having premised these few general remarks on the effects of climate on the vegetation of the district, I shall be enabled to give a more correct notion of the particular productions by enumerating and briefly describing those plants which are most remarkable, either for rarity, beauty, or peculiarity of structure.

In the earlier editions of this little book I drew the attention of my readers to the flora of the district, and mentioned a large number of plants of unusual occurrence elsewhere, but here presenting themselves in such profusion as to characterize the vegetation. During the thirty years that have since elapsed I have visited many parts of England, Ireland, and Scotland, and have nowhere, except high up in the mountains, observed so great a variety of unusual plants. Many of them it is true are of humble growth, and consequently escape the notice of ordinary tourists. But to the sharp-eyed botanist I firmly believe that no extent of country of equal di- 
mensions, except as I have said the sub-alpine regions, produces so many rare and characteristic plants as the Lizard district. Long before "A Week at the Lizard" had been thought of I had contributed to one of the Botanical Magazines a paper, in which, commenting on the abundance of the Leguminosæ in the district, I said that I had actually covered with my hat no less than twelve distinct species of this tribe, growing in the turf near the Lizard Head. My paper was discussed at a meeting of a Botanical Society, and a member observed that "the writer must wear a very large hat." It was in fact a straw hat with a broad brim; nevertheless, the statement was actually true, and having been investigated by competent botanists, was so far confirmed that, in the map engraved for the British Association at their Meeting at Exeter (in I870?), the peninsula of the Lizard is set down as "District of Leguminosæ."

The number of species known to inhabit this district is no less than forty-one, namely:-

\section{Sarothamnus scoparius, Broom.}

Ulex Europæus, Furze.

,, nanus.

,, ,, (var.) Gallii.

Genista 'tinctoria, (rar.) humiíusa, Wood.

, Anglica.

", pilosa.

Ononis arvensis, Rest-barrow.

Anthyllis vulneraria, Lady's fingers.

,, (var.) Dillenii.

Medicago lupulina, Medick.

, maculata.

,, denticulata. 
Melilotus officinalis, Melilot.

Trifolium repens, Trefoil.

,, pratense.

,, subterraneum.

,, Molinerii.

, medium.

,, $\quad$ hybridum $\}$ elegans $\}$ naturalised.

, arvense.

,, scabrum.

,, striatum.

, Bccconi.

, strictum.

,, frugiferum.

", procumbens.

, minus.

", filiforme.

", ornithopodioides.

Lotus corniculatus, Bird's-foot Trefoil.

," , (var.) tenuis.

, diffusus.

," major.

,, hispidus.

Ornithopus perpusillus, Bird's-foot.

Vicia cracca, Vetch.

, sativa.

,, ,, (var.) angustifolia.

, lutea.

", hirsuta.

,, tetrasperma.

,, Orobus.

Lathyrus pratensis, Yellow Vetchling.

Another great characteristic feature in the botany of the district is the extreme abundance of the Cornish or Goonhilly heath. It may be said to grow over the whole country from Mullion to the Blackhead, except where it has been extirpated by the plough. Every hedge-bank and roadside is full of it, and if we enter the cottages, turf composed of it, mixed with smaller plants, is the only fuel. The Cornish heath is 
not confined to the Serpentine soil, as is frequently stated, but may be found on Devonian in several places near Carminowe Creek, also on hedges about a mile from Helston on the Lizard road. It also occurs on Connor Down, near

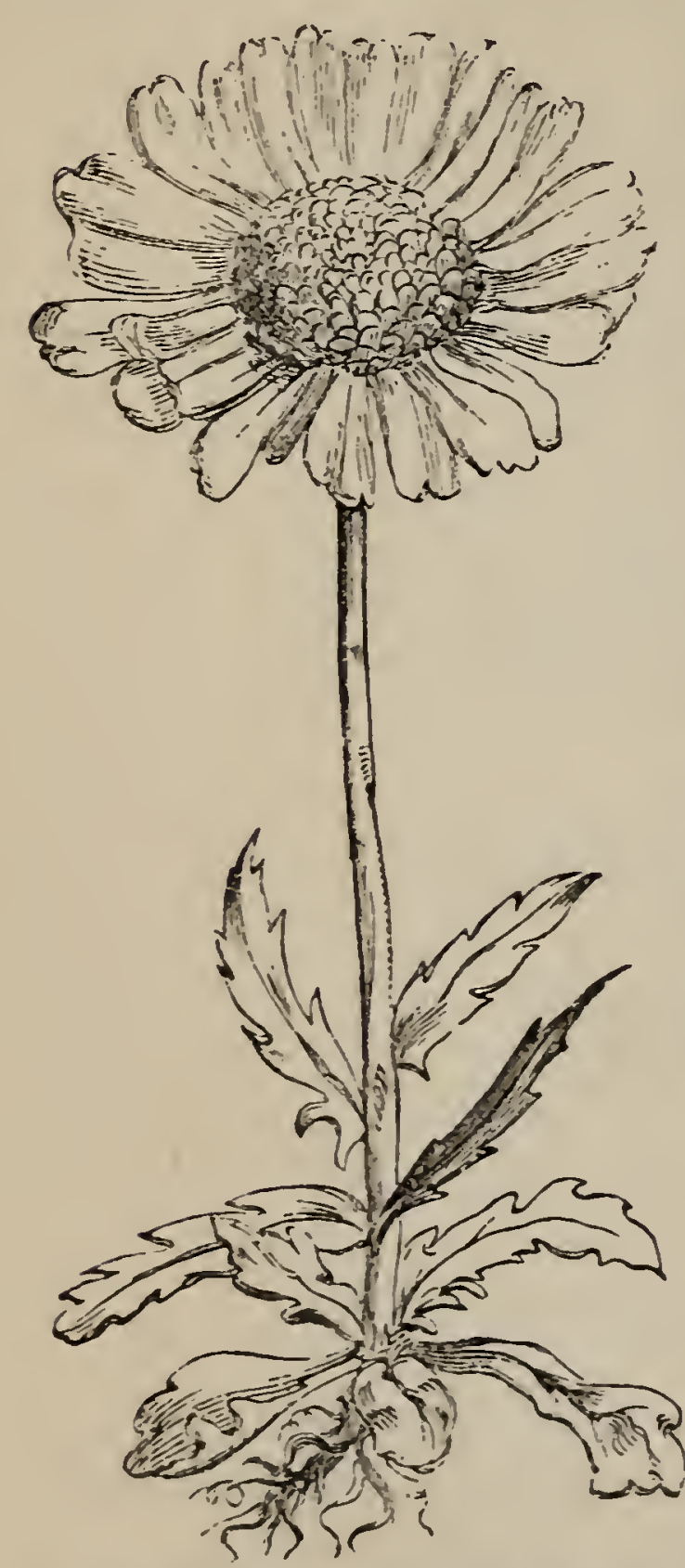

STUNTED OX-EYE DAISY.

Hayle, and in the parish of Mylor, near Penryn. It is a widely-distributed plant, growing on the coast of the Mediterranean, Western France, Dalmatia,Turkey, Greece, Syria, and Crete.

Near the verge of the cliffs most of the plants are either different from those which we meet with inland, or their character is altered by exposure to an atmosphere charged with salt. Thus we find common groundsel and eye-bright with thick fleshy leaves and stems but little branched; the ox-eye daisy and sheep's scabious diminished to the height of a few inches, and likewise furnished with fleshy leaves and stems. 'The rare and otherwise interesting plants are numerous. I will therefore mention them as they would fall in the way of the tourist exploring the coast from the banks of the Loe eastward round 
the coast and proceeding inland whenever necessary.

On the banks of the Loe Pool are to be found several plants more or less rare, which the botanist will be glad to have the opportunity of examining in their fresh state, and of which he will probably bear away a few specimens for his herbarium.

Lastrcea recurva, a very pretty fern, distinguished by the crisped appearance presented by its leaves, grows by the roadside in a little wood half-way between Helston and Penrose, and in several other similar situations. The crisped appearance alluded to is owing to the curling upwards of the extremities of the leaflets, a character peculiar to this fern.

The furze and heath

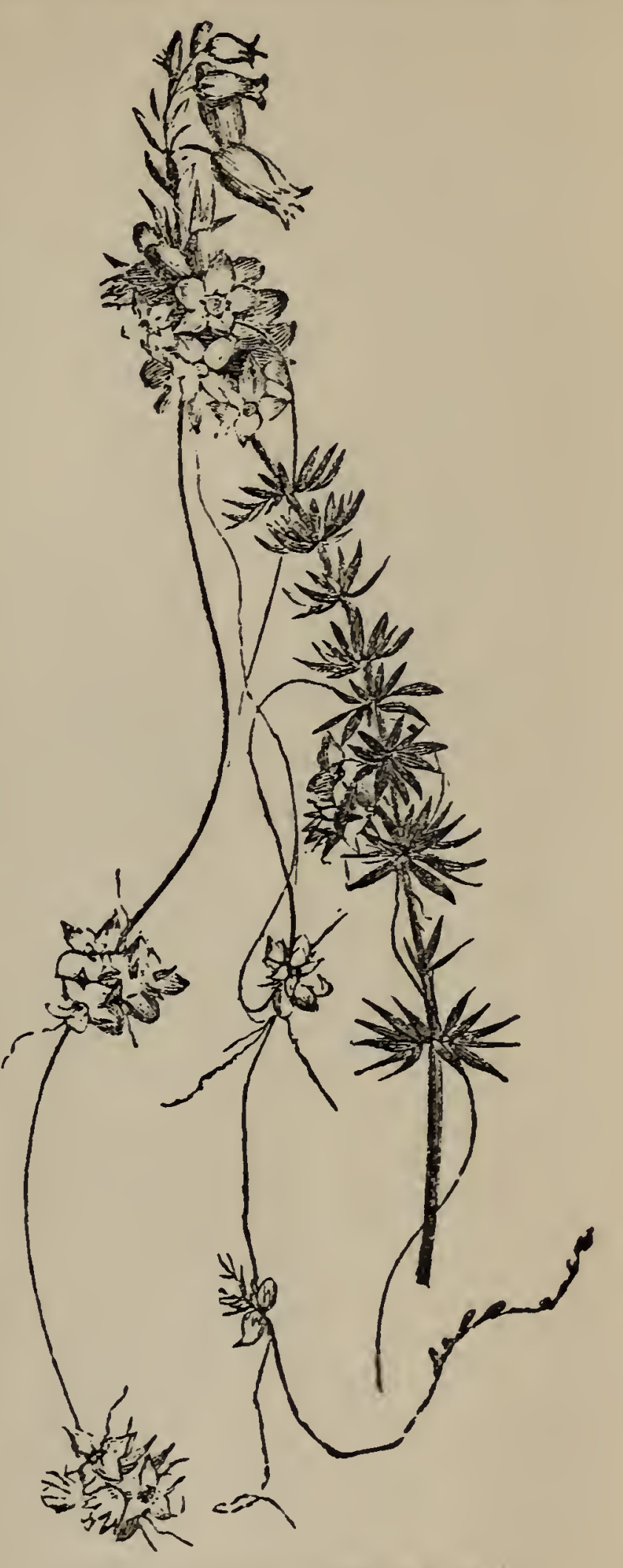

CUSCUTA EPITHYMUN. in this neighbourhood are greatly infested by Cuscuta Epithymum, Lesser Dodder, a para- 
sitical plant, composed of innumerable red threads, which are firmly attached to the stems of the plant on which it grows, and almost conceal it from sight. It is destitute of leaves, but bears heads of beautiful wax-like flowers of a light pinkish hue.

Viola lactea-Cream-coloured Violet-which may be known by its pale flowers and lanceshaped leaves, is plentiful in Degibna Wood; and with it may be found Melittis melissophyllum, which may be at once recognised by its large serrated leaves resembling the common Balm and its handsome labiate flowers, which are white blotched with purple.

Corrigiola littoralis, Strapwort, is a pretty little plant, with slender trailing branches from three to six inches in length, which grows among the shingle on various parts of the shore of the Loe Pool. It may be distinguished by its narrow glaucous leaves, and numerous heads of minute white flowers; it is remarkable for possessing the singular habit of shifting its habitat from one part of the shore to another, almost every year. Sometimes, for instance, it abounds in the slaty beach at Penrose, but scarcely a single specimen is to be found on the opposite side of the lake; next year, perhaps, it grows in profusion on the eastern beaches, but has disappeared from its former station. It is rarely to be found in equal abundance on all parts of the shore. This wandering habit may thus be accounted for:-it is an annual, and always grows in situations which in winter are covered by the 
water. As the water rises it buoys up the seeds on the surface, and they are driven by the wind in whatever direction it may be blowing, until they are thrown on the opposite shore. In the following season the plants abound on the side opposite to that from which the wind was blowing when the water rose. The Strapwort grows nowhere in Britain but here and in two places in Devonshire. Chenopodium polyspermum, many-

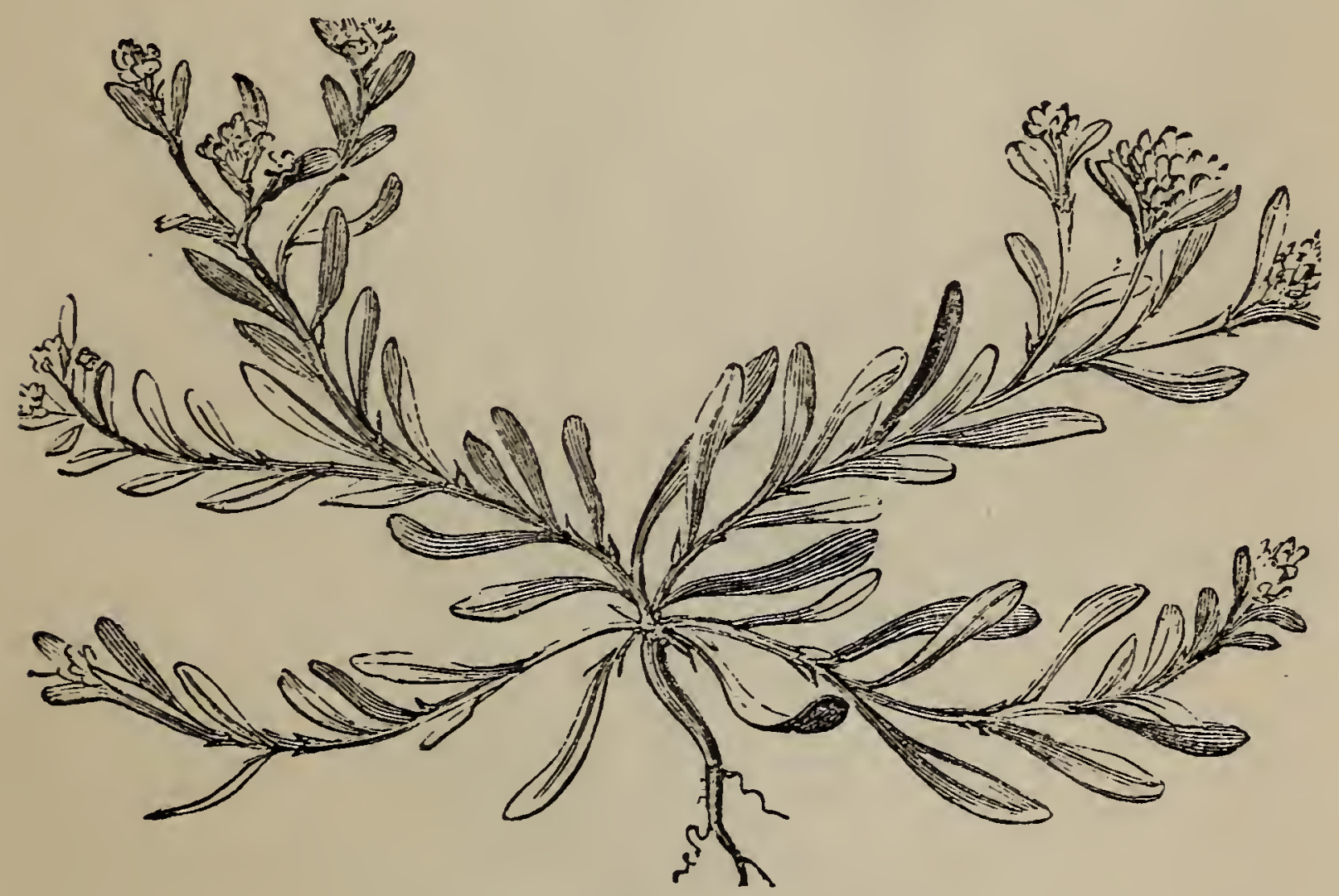

CORRIGIOLA LITTORALIS.

seeded Goosefoot, grows in similar situations with the Strapwort. It may be distinguished from the other species of the same genus by its ovate obtuse leaves, which are tinger and veined with red, its numerous clustered flowers, and its brown, shining, flattened leaves.

Among the grassy turf, at the same places, grows Littorella lacustris, Plantain Shore-weed. This was formerly called the single-flowered 
Plantain, which in habit it closely resembles. It is a small plant, bearing long and fleshy leaves, from among which rises a single flower with four stamens, the most conspicuous part of the plant.

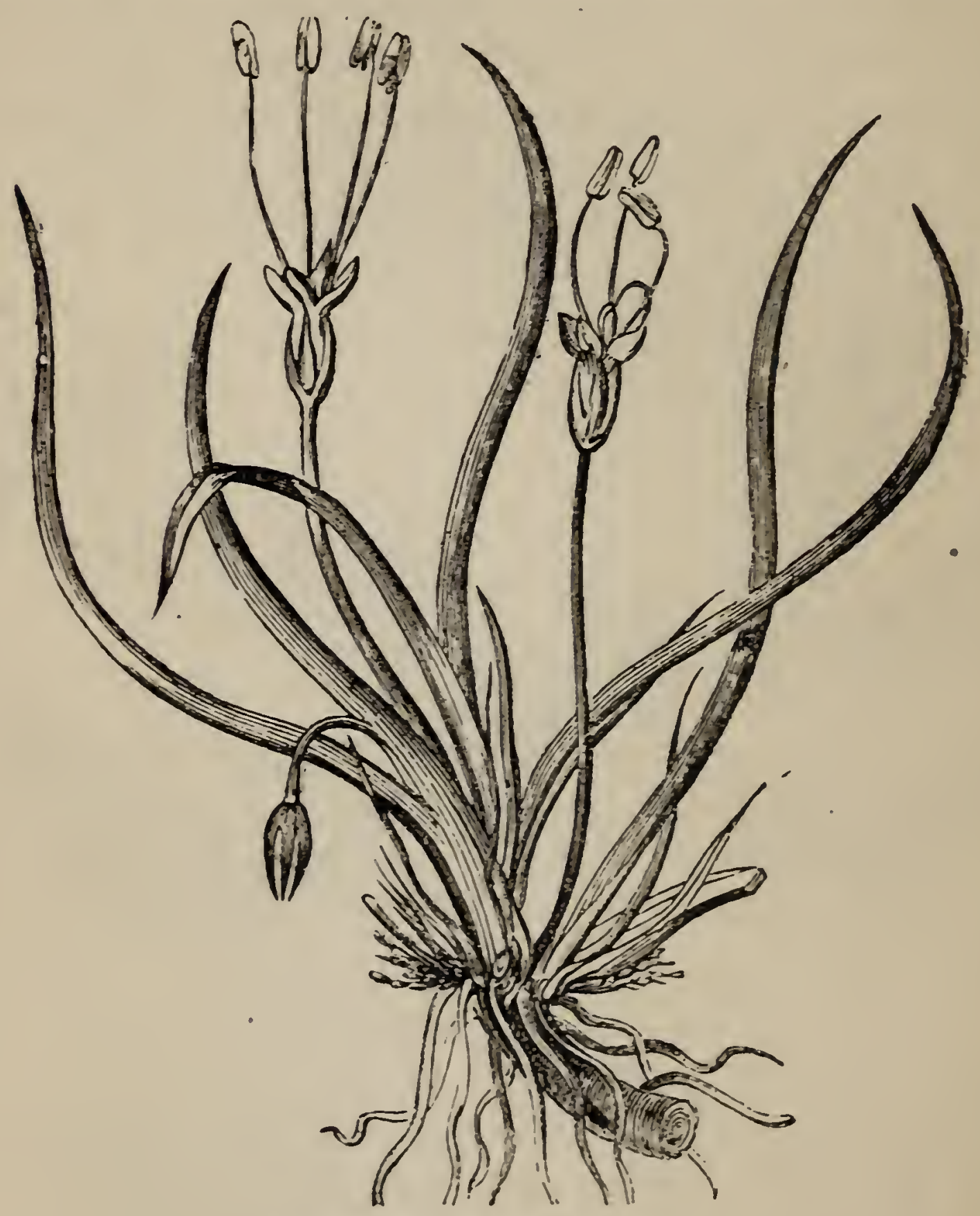

LITTORELIA LACUS'TRIS.

It grows also in several places on the Lizard Downs, especially where water has stood during. winter.

Penrose Creek is filled with a coarse-looking plant, which, except during the flowering season, 
is anything but ornamental. This is Polygonum amphibium, Amphibious Persicaria; it grows either in the water, or on the muddy edge of the lake; in the former situation, its leaves, which are oblong and rough-edged, float on the surface; in the latter the leaves are erect and somewhat shorter; each stem terminates in a spike of rosecoloured flowers.

In summer the whole of the lake, except some of the very deepest parts, is filled to the surface with tangled weeds, which greatly interfere with the sport of the fishermen; these are Potamogeton perfoliatus and $P$. pusillus, perfoliate, and small, Pondweed. The former of these is a straggling branched stem, which in deep water is many yards long, and is furnished at intervals of a few inches with broad membranous leaves, clasping the stem with their bases. The extremity of the stem bears a spike of dull green flowers, the only part of the plant which rises above the surface. So membranous are the leaves that they are almost transparent, and if placed when dry on the warm hand, will curl up like the thin shavings of horn which are sold under the name of Chinese sensitive leaves. This peculiarity is attributable to the cellular structure of its substance and the contraction of its membrane under the agency of heat. The lesser Pondweed is a tangled mass of slender stems and grass-like leaves, with flowers resembling those of the larger species, only much smaller.

Pyrus torminalis, Wild Service-tree, grows among the brushwood near the Bar of sand, and also immediately over the old adit called Duff's- 
hole. In foliage it resembles the Maple, in flower the Mountain Ash, and frequently grows to a large tree; here, however, it is only a few feet high.

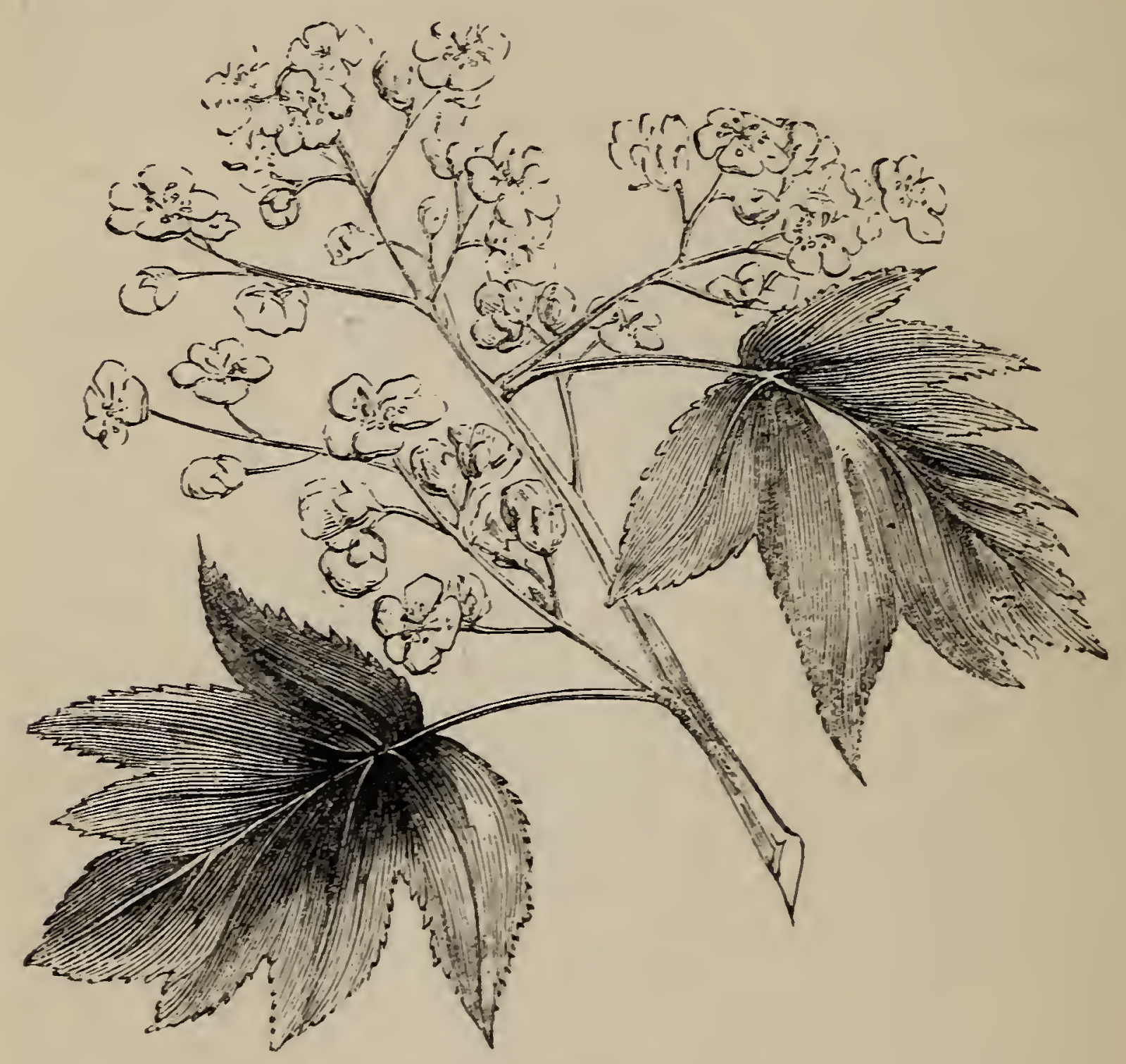

PYRUS TORMINALIS.

Euphorbia Portlandica, Portland Spurge, grows in considerable abundance among the rocks immediately over the Bar; though a small plant, it may be distinguished at some distance by its bushy habit, and the red hue of its stems and lower leaves. Like the rest of the Spurges, it abounds in a milky juice, which, if not actually poisonous, is intensely acrid and unpleasant to 
the taste. It is one of the few plants said to be peculiar to the British isles.

The turf on the verge of the cliff for many miles

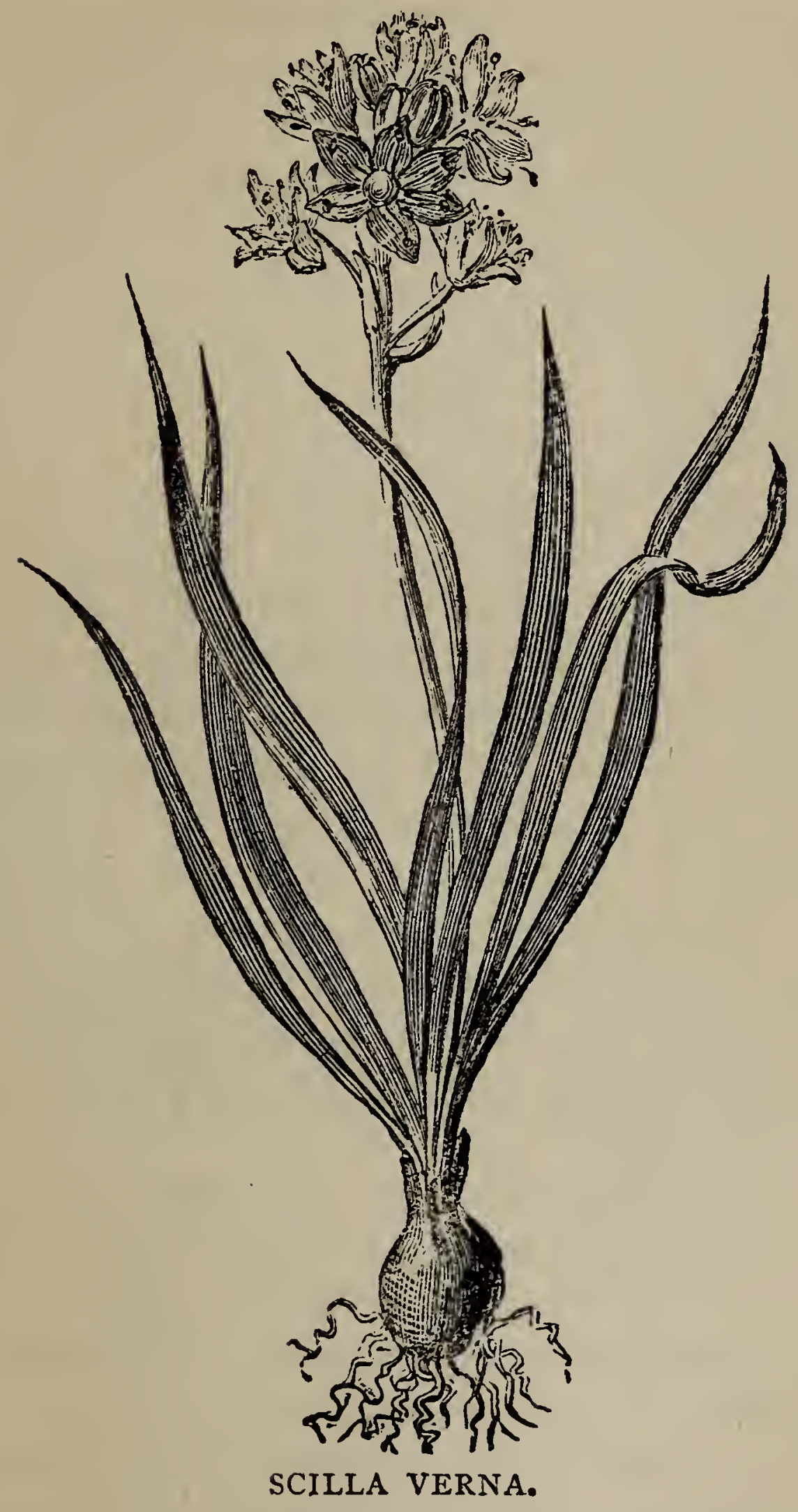

of this coast is, in spring, studded with countless sky-blue star-like flowers of Scilla verna, Vernal 
Squill (see page 2 I9), a lowly unpretending plant, which, though of delicate texture and elegant form, makes its home in the most exposed situations. No British flower confers a greater grace on its haunts than this. Its sole fault is, that it remains in blossom during a few weeks in May and June only; before midsummer it has disappeared, its place being occupied by its threecelled seed-vessels, which are conspicuous even after they have been dried up and bleached by the sun, and have shed the black shining seeds which they contained. In the months of August and September, Scilla autumnalis, Autumnal Squill, a plant resembling the vernal species, but much less beautiful, comes into flower here and there along the coast, but is nowhere, except at Cudden Point, so abundant as to form a distinct botanical feature. Its flowers are more pyramidal in their mode of growth, and of a dingy hue. The leaves do not appear until the flowers have faded. Its bulbs are so tenacious of life, that I have frequently stored away specimens in flower, and, on examining them some weeks after, found the petals faded, but new leaves shooting out most vigorously.

At the sandy base of the cliff which skirts the Loe Bar, occurs Convolvulus Soldanella, Sea Bindweed. It may readily be detected by its fleshy leaves, and large handsome flowers, which are scarcely elevated above the surface of the sand. The flowers only expand in bright weather, and are of very short duration; they are light pink, with darker stripes of the same colour, and are so delicate that they will scarcely bear being 
gathered without becoming ragged at the edges.

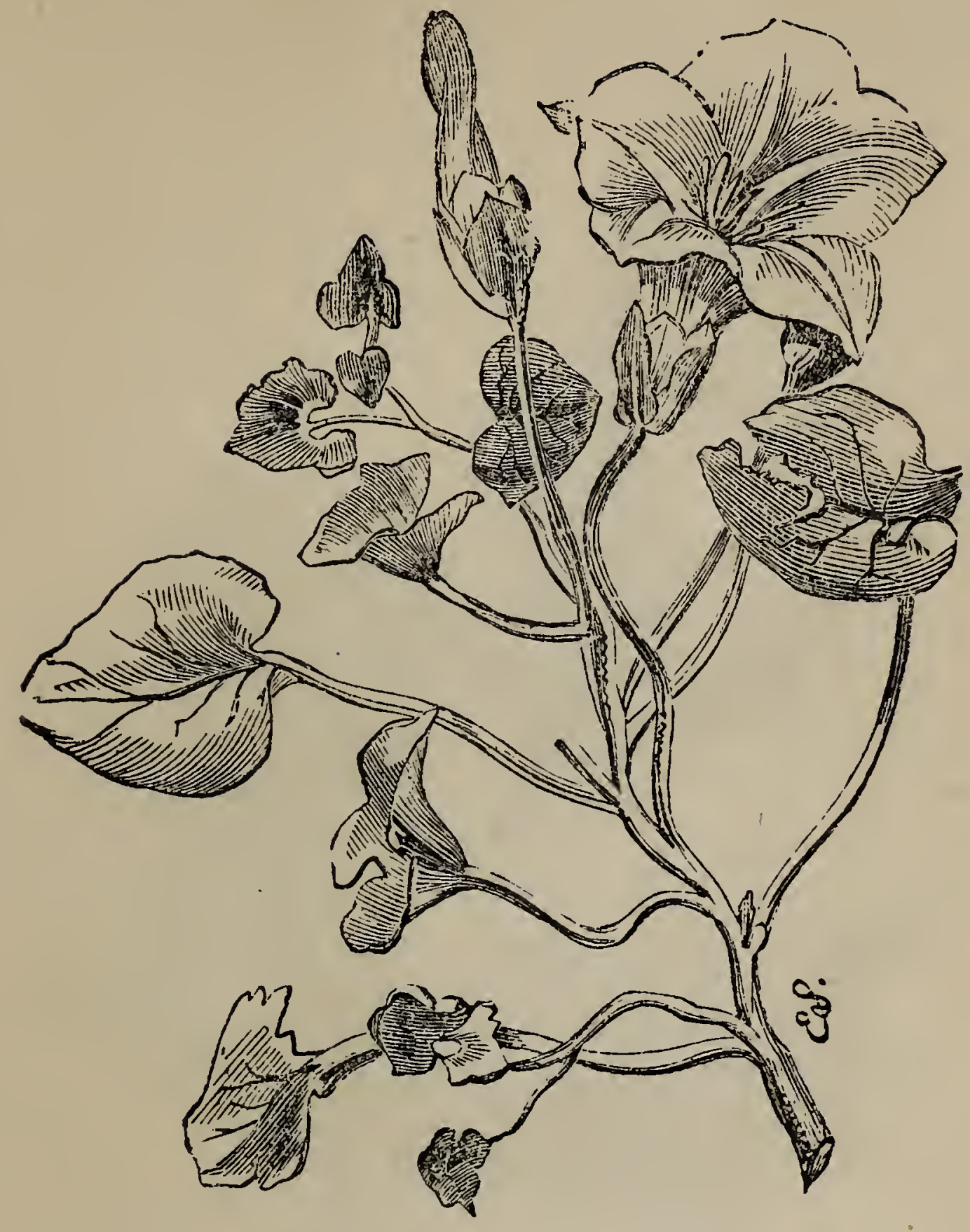

CONVOLVULUS SOLDANELLA.

Eryngium maritimum, Sea Holly, sends its long cylindrical roots deep into the sand of the Bar; it has much the character of a thistle, but in reality is one of the umbelliferous tribe. It is well marked by its stout prickly leaves and purplish-blue heads of flowers; the whole plant is covered with a glaucous or bluish-white bloom, 
which identifies the plant, even if seen from a great distance. Its roots are made into a sweetmeat, which is well known under the name of "candied Eryngo-root."

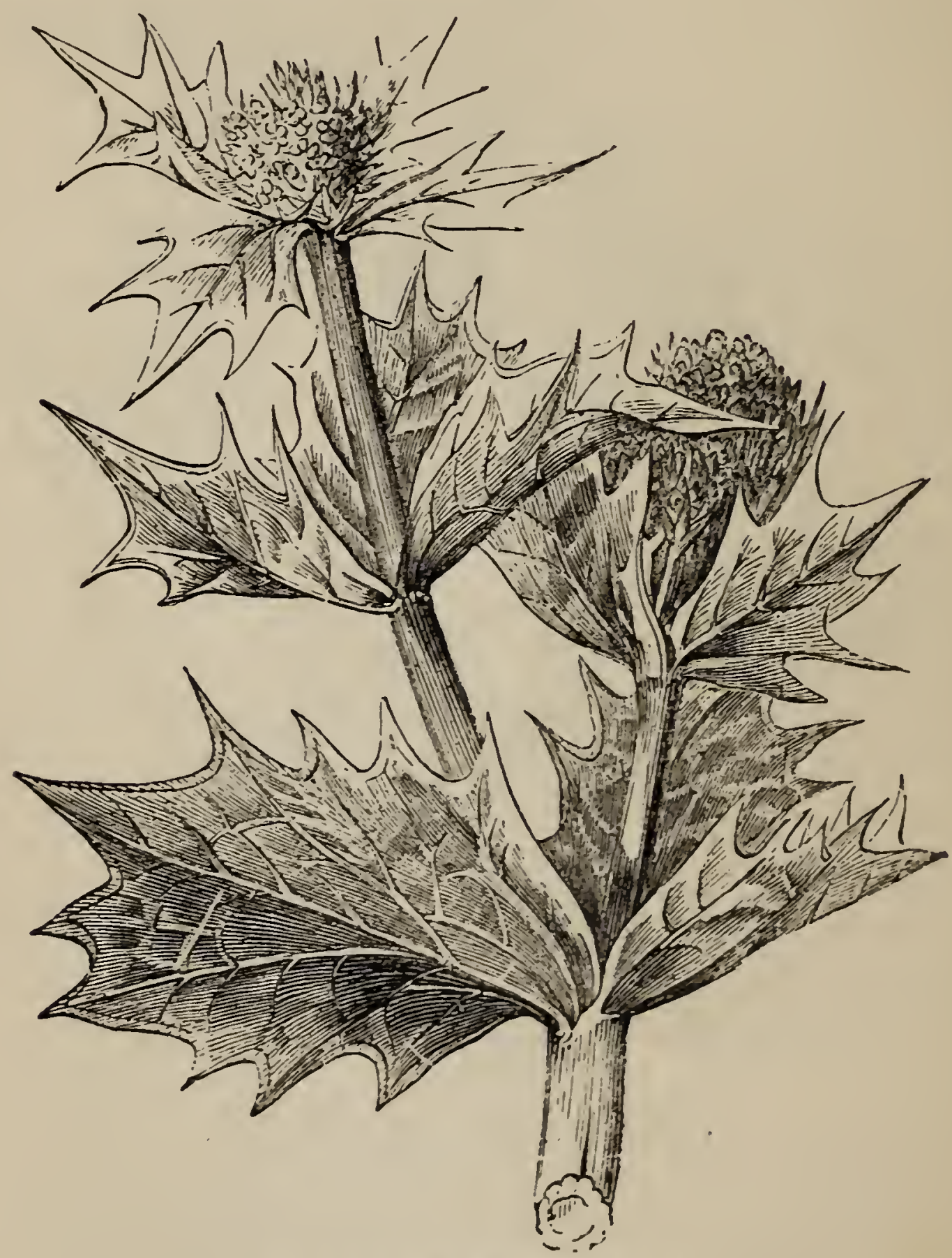

ERYNGIUM MARITIMUM.

Polygonum Raii, Sea-side Knot-grass, is a straggling wiry plant, with narrow fleshy leaves and small pinkish flowers, which grow in their axils, and are succeeded each by a large, trian- 
gular, polished seed, which is longer than the calyx. It grows quite prostrate on the sand. The last-named three plants occur also at Gunwalloe, Kennack, and on most parts of the sandy coast.

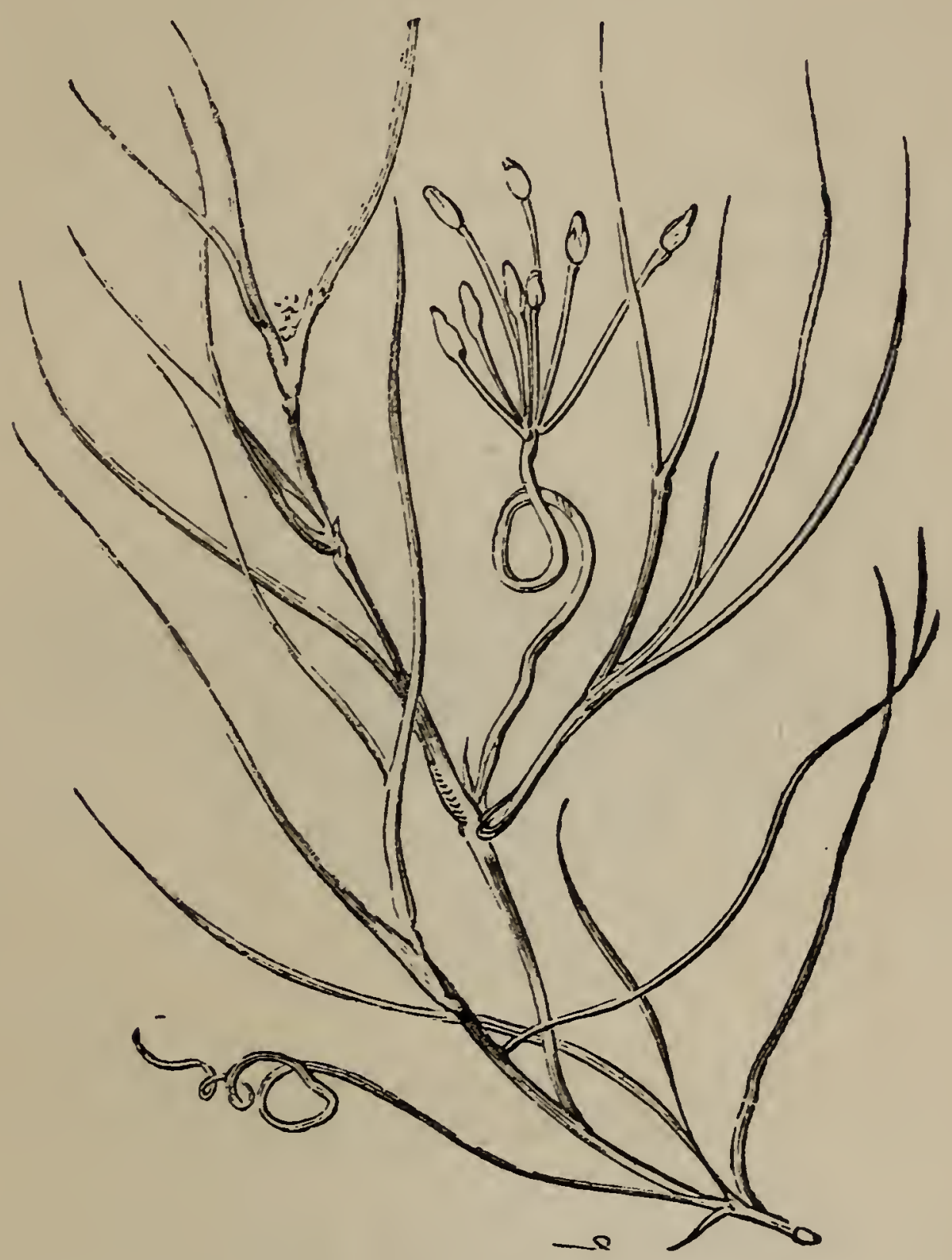

RUPPIA MARITIMA.

Ruppia maritima, Sea Ruppia, might at first sight be mistaken for a plant already mentioned, Potamogeton pusillus, from which it is best distinguished by the spiral support of its flowers, and its stalked seeds. The flowers in their early stage are entirelysubmersed; but as it is necessary 
to the welfare of the plant that they should cxpand in the air, their stalk is spirally elongated as they approach perfection, until the blossoms are raised above the surface of the water; after a time, the spiral contracts, the stalk is again submersed, and the seeds are ripened under water. This plant grows between the Bar and Carminowe Creek. As its name indicates, it is a salt-water plant, but is occasionally found, as in this case, in ponds and lakes into which the sea flows but rarely.

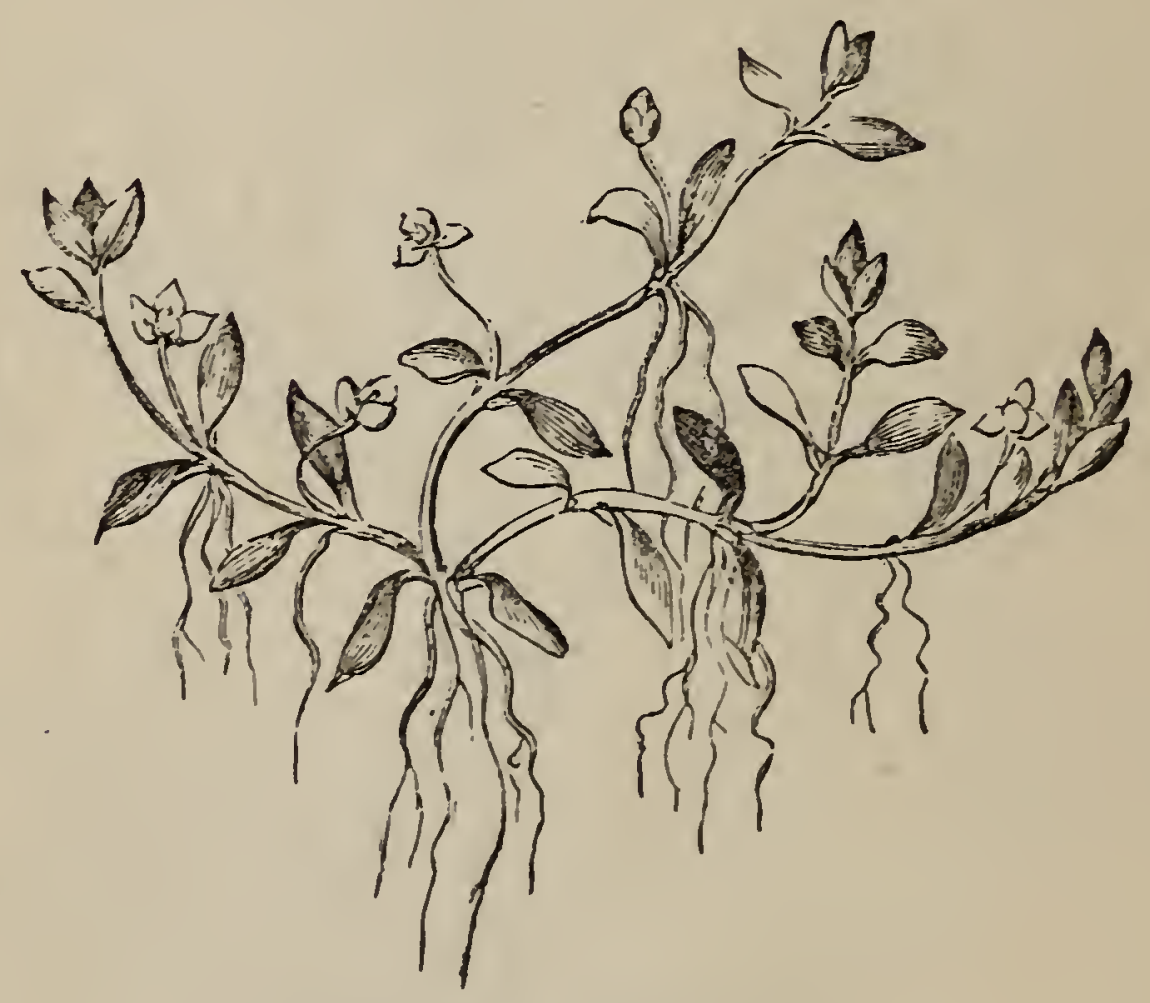

ELATINEE HEXANDRA.

Bidens tripartita, Trifid Bur-marigold, and Alisma Plantago, variety lanceolata, may be found in the autumn at the mouth of the rivulet at the head of Carminowe Creek, \&c.

Chenopodium botryoides, Many-spiked Goosefoot, has little to recommend it but its rarity; it grows on the flat alluvial soil, at the head of Carminowe Creek, having prostrate stems, 
toothed fleshy leaves, and numerous spikes of small green flowers.

The muddy bottom of the Loe Pool in Carminowe Creek is in many places covered by a turf of Elatine hexandra, Water-wort (see p. 224), a minute succulent plant, with greenish flowers of three petals. It is principally worthy of notice for its rarity and the exquisite beauty of its seeds, which, seen under a microscope, appear polished

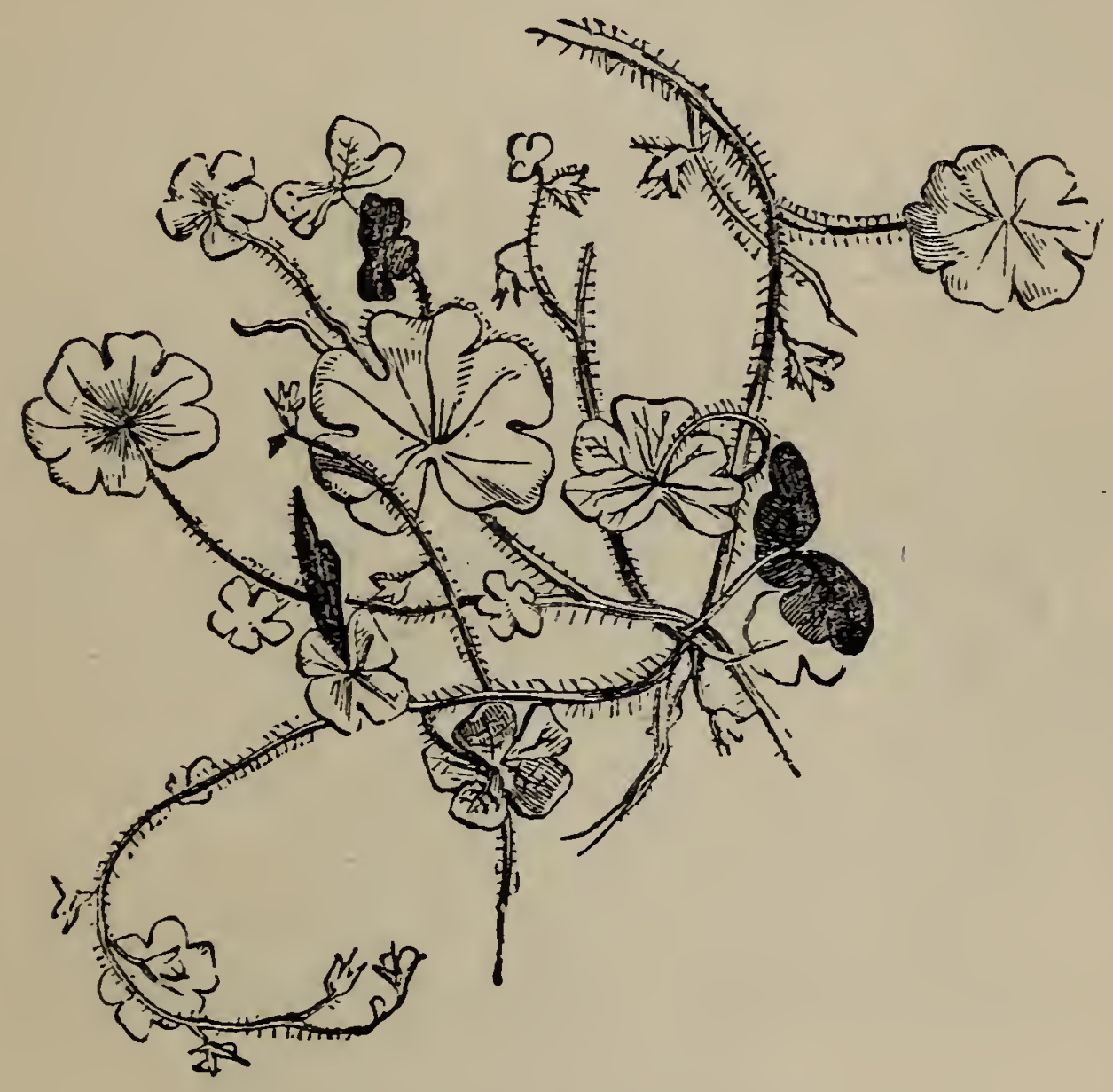

SIBTHORPIA EUROPFA.

and most elaborately ribbed and striated. When left growing on the shore by the receding water, the whole plant assumes a deep red hue.

Cornwall is remarkably rich in minute flowering plants which inhabit wet places, and most of which are either unknown or far from common in the more eastern counties. Sibthorpia Europaca, 


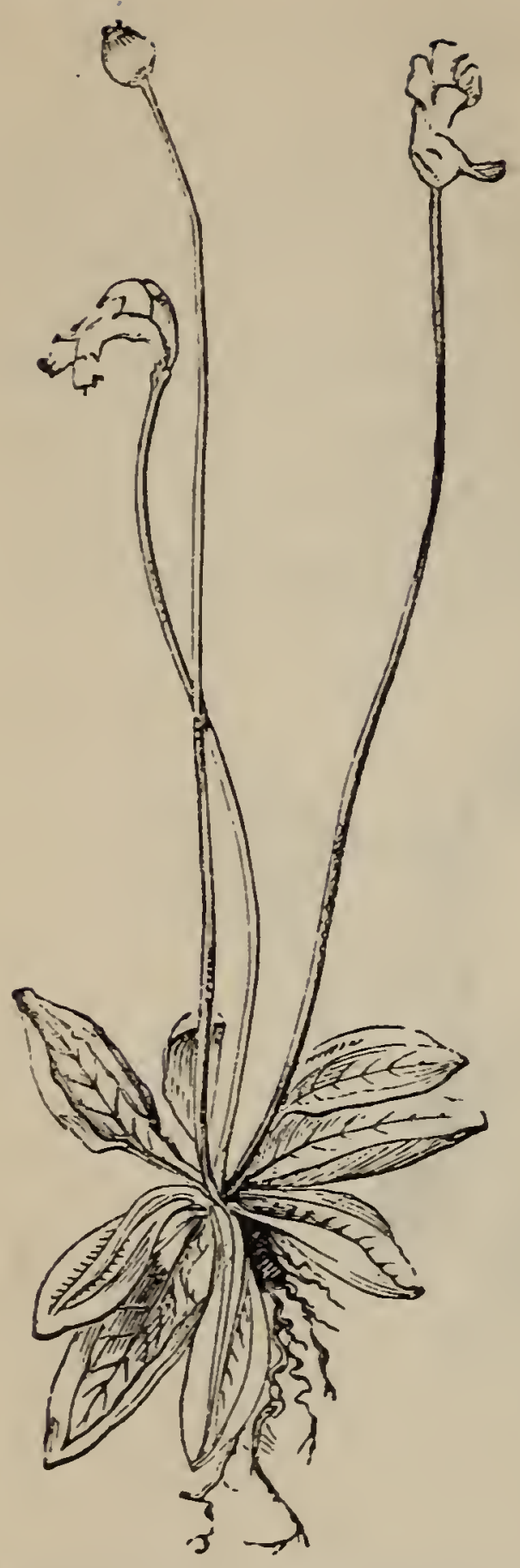

PINGUICULA LUSITANICA.

Cornish Money-wort (see p. 225), with its trailing threadlike stems, beset with orbicular notched leaves and tiny flesh-coloured flowers, clothes the sides of every trickling rill; and with it is usually associated Campamula hederacea, Ivy-leaved Bell-flower, a lovely little plant with a stem almost as fine as a hair, and so frail, that were it not for the assistance rendered by its stouter neighbours, it could scarcely raise its flimsy blue bell above an inch from the ground. Where these two grow, we may reckon with certainty on finding the commoner, but scarcely less beautiful, Anagallis tenella, Bog Pimpernel, with its creeping wreaths of shining round leaves and rose-coloured flowers. A more lovely sisterhood of fairy flowers can scarcely be imagined. Pinguicula lusitanica, Pale Butterwort, is another minute but elegant plant, with pale pink blossoms shaped somewhat like the violet, and supported singly on a slight perpendicular stalk about three inches high. The flower-stalks rise from a tuft of greenish white leaves singularly veined, and greasy to the touch, whence it derives its name. 
Its roots are so small as scarcely to attach the plant to the spongy soil in which it delights to grow.

Centunculus minimus, Small Chaff-weed, frequents the gravelly banks in the neighbourhood of marshes, and closely resembles a Pimpernel in habit: it rarely exceeds an inch in height. Radiola millegrana, Flax-seed, grows in similar situations, and attains an equal elevation; it is much more slender and more minutely formed than the last, and, being repeatedly branched and

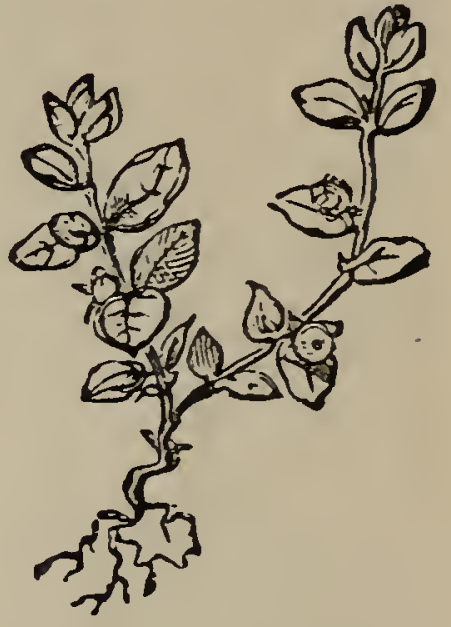

CENTUNCILUS MINIMUS.

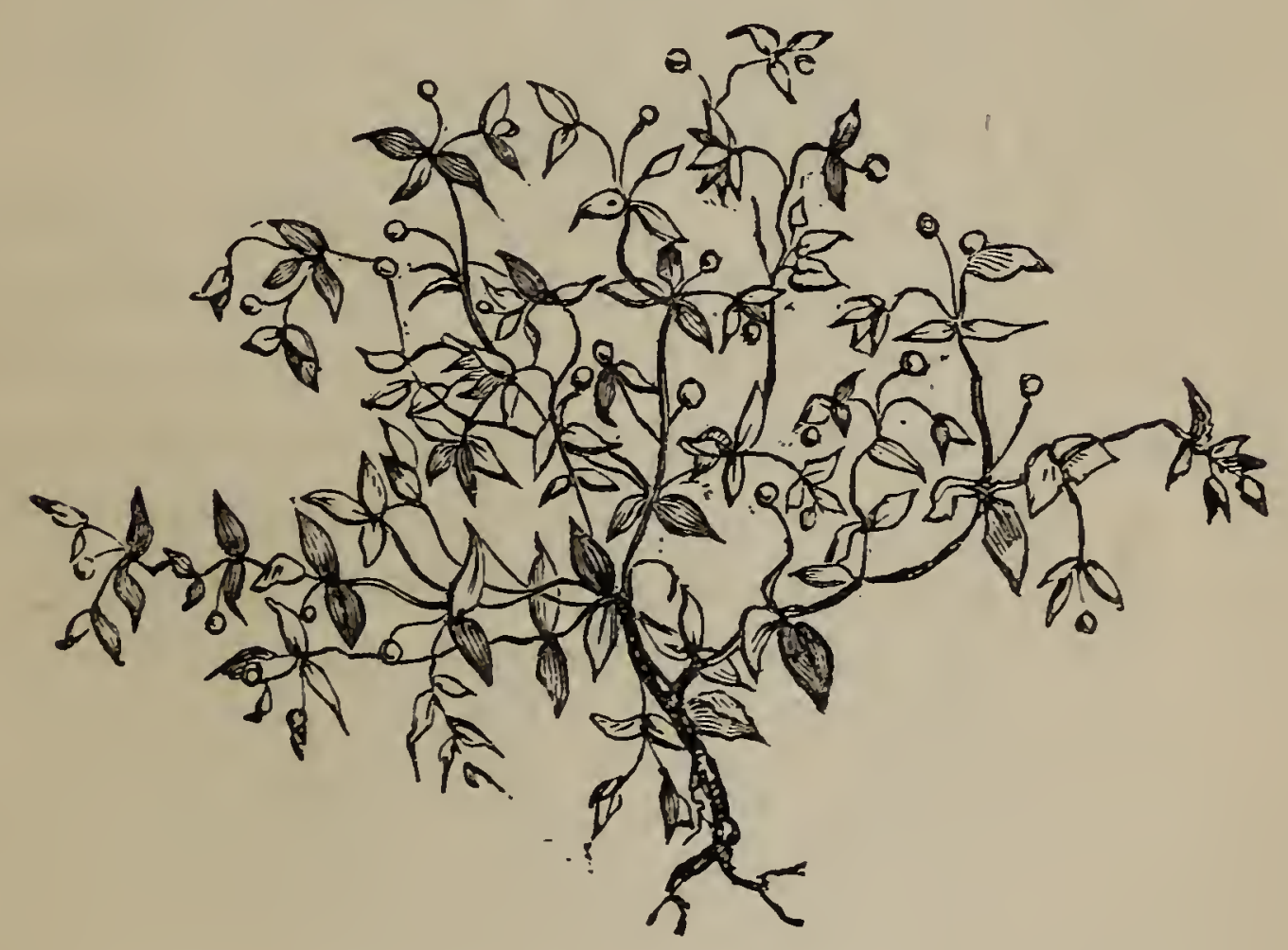

RADIOLA MILLEGRANA.

thickly loaded with leaves and flowers, has the habit of a perfect shrub. The last two plants are figured of the natural size, and the. whole of 
the tiny group are to be found on the banks of the lake.

In a little common above Carminowe Creel: grows Gymnadenia conopsea, Sweet-scented Orchis, which betrays its identity by its fragrance. Linaria minor, Least Toad-flax, may be met with in some of the adjoining fields. It occurs also on Grade Downs, near the Lizard.

In Degibna Wood, Erica gavans, Cornish Heath, is abundant, and flowers freely, though it does not here reach a size equal to that which it attains on the serpentine formation. It is botanically distinguished from the other British Heaths, by its anthers forming a ring outside the bell-shaped corolla. Erica ciliaris, Ciliated Heath, the most beautiful British species, confines itself to Cornwall, like the last, but does not grow in the Lizard district.

In the little valley extending south of Carminowe Creek may be found Hypericum undulatum, Wavy-leaved St. John's-wort. It may be distinguished from the square-stemmed St. John's-ivort, which it most nearly resembles, by its red-coloured stem and its deep yellow-coloured petals, which are tinged with bright red and fringed with black glands. The leaves are curled or undulate. It was first noticed by Mr. James Cunnack, of Helston, and subsequently by Mr. Briggs, of Plymouth.

Still continuing our way round the coast, we pass the Halzaphron Cliffs, and, on the promontory beyond, fall in with Genista tinutoria, $\beta$. prostrata, Dyer's Green-weed, a low shrubby plant, with numerous clusters of bright yellow 
flowers. All parts of this plant furnish a good yellow dye.

Genista Anglica, Needle Green-weed, grows on many parts of the Lizard and Goonhilly Downs. It is well marked by its inflated seedvessels, and by having the lower part of its stems clothed with slender thorns. In the course of drying, its petals turn to a lurid green.

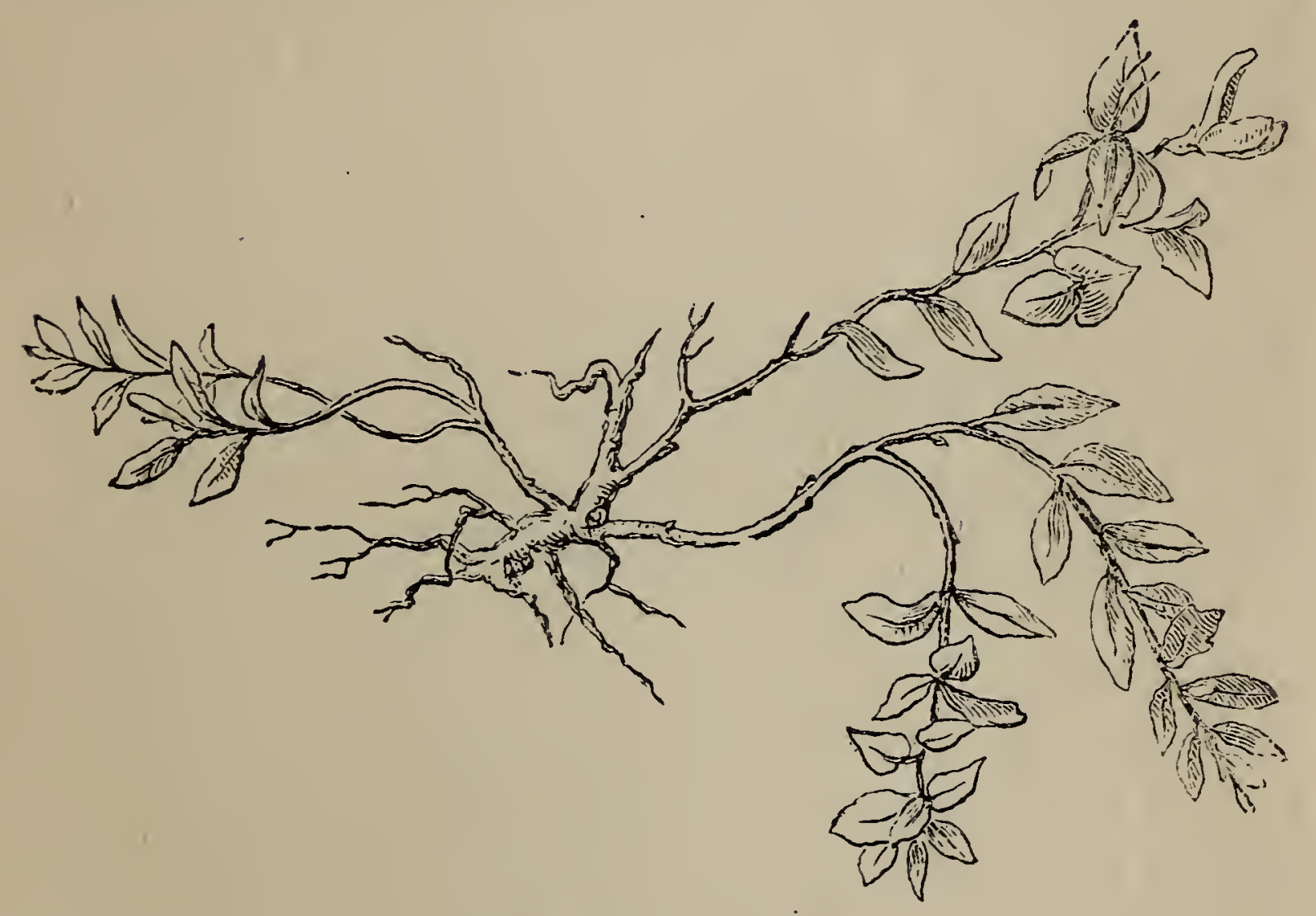

GENISTA TINCTORIA.

Genista pilosa, Hairy Green-weed, a much rarer species than either of the above, grows at intervals along the cliffs. It is distinguished by its humbler mode of growth, knotted woody stems, and silky leaves, which are folded together. It blossoms in May, and, if the summer be not too dry, again in September. Genista tinctoria, the first-mentioned species, is abundant on many 
parts of the Lizard coast, flowering from June to the end of August.

On the same promontory, somewhat more inland, grows Oplizoglossum viulgatum, Adder'stongue, a remarkable fern, consisting of a single undivided egg-shaped leaf, from the base of which rises a tapering spike of fructification marked like the tail, rather than the tongue, of a snake. It is not easily detected, owing to its uniform green hue, and its growing in a turf composed of plants of about the same size with itself.

In the corn-fields about Gunwalioe grow several plants which, though not peculiar to the district, are sufficiently rare to merit notice. Brizaminor, Small Quaking-grass, is one of the most elegant of the British grasses. The stem is about two feet high, and bears a profusion of small triangular spikelets, each of which is placed at the extremity of a stalk so fine as to be barely visible, and dances to the music of the lightest breath of heaven. The specimen now before me contains about five hundred of these spikelets, each of which is about seven-flowered; so that the total number of flowers on one stalk is no less than three thousand, and there are often four or five such stems springing from a single root. If gathered before the seeds are quite ripe, this beautiful grass retains its shape and silver-green hue for a long time and, if protected from dust, forms an elegant addition to bouquets of winter flowers.

Linaria spuria, Round-leaved Toad-flax, is a small-trailing plant with flowers shaped like those of the Snap-dragon, but furnished with a sharp 
spur at the base ; their colour is very remarkable, the upper half being yellow, the lower bright purple.

Lamium amplexicaule, Henbit-nettle, differs from the common red Dead-nettle in having its leaves irregularly cut, and its flowers clasped by the upper stalkless leaves.

Ranunculus hirsutus, Pale Hairy Crowfoot, here begins to take the place of the more common species, $R$. bulbosus and $R$. acris. It is distinguished by its spreading calyx and rough-margined seed-vsssels. It is abundant in waste places throughout the Lizard district, and occasionally produces double flowers.

As we descend towards Gunwalloe Church, we find by the way-side Trifolium fragiferum, Strawberry-headed Trefoil, so called from the resemblance which its heads of pink inflated calyces bear to that fruit. In habit it approaches nearest to $T$. repens, Dutch Clover, growing luxuriantly. The latter plant is abundant here, as everywhere, but is remarkably early in expanding its flowers, which are generally in perfection a full month before it begins to bud in inland meadows.

Senecio erucifolizis, Hoary Rag-wort, much resembles the common form, but may be distinguished by the leaves being downy underneath and the stem loosely cottony; plentiful on the hedge on the right hand side.

Lithospermum officinale, Grey Millet, is a leafy erect plant about two feet high, branched at the top, and bearing small cream-coloured flowers, which are succeeded by comparatively large seeds 
of a bluish grey colour, hard, and so highly polished as to resemble marine shells. The unusual hardness of the seed-case is to be attributed to the presence of a considerable quantity of flint, lime, and iron.

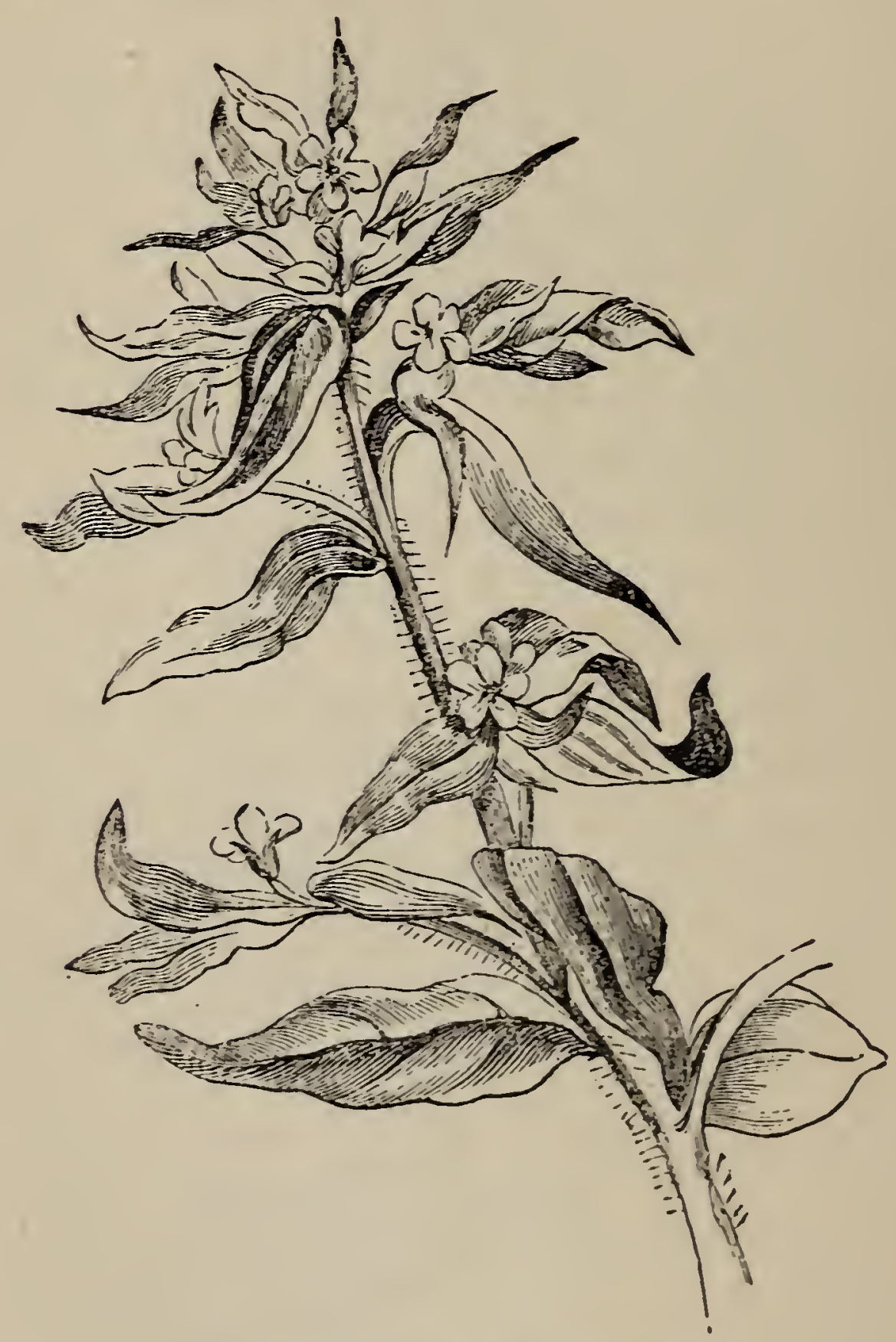

LITHOSPERMUM OFFICINALE.

Helminthia echioides, Bristly Ox-tongue, with yellow composite flowers, and large leaves bristling with short hairs.

In waste places near the sea, Hyoscyamus niger, 
Henbane, is a very picturesque plant, with its broad wavy leaves and stems furnished with rows of large vase-like seed-vessels. Its flowers are cream-coloured, intricately veined with deep

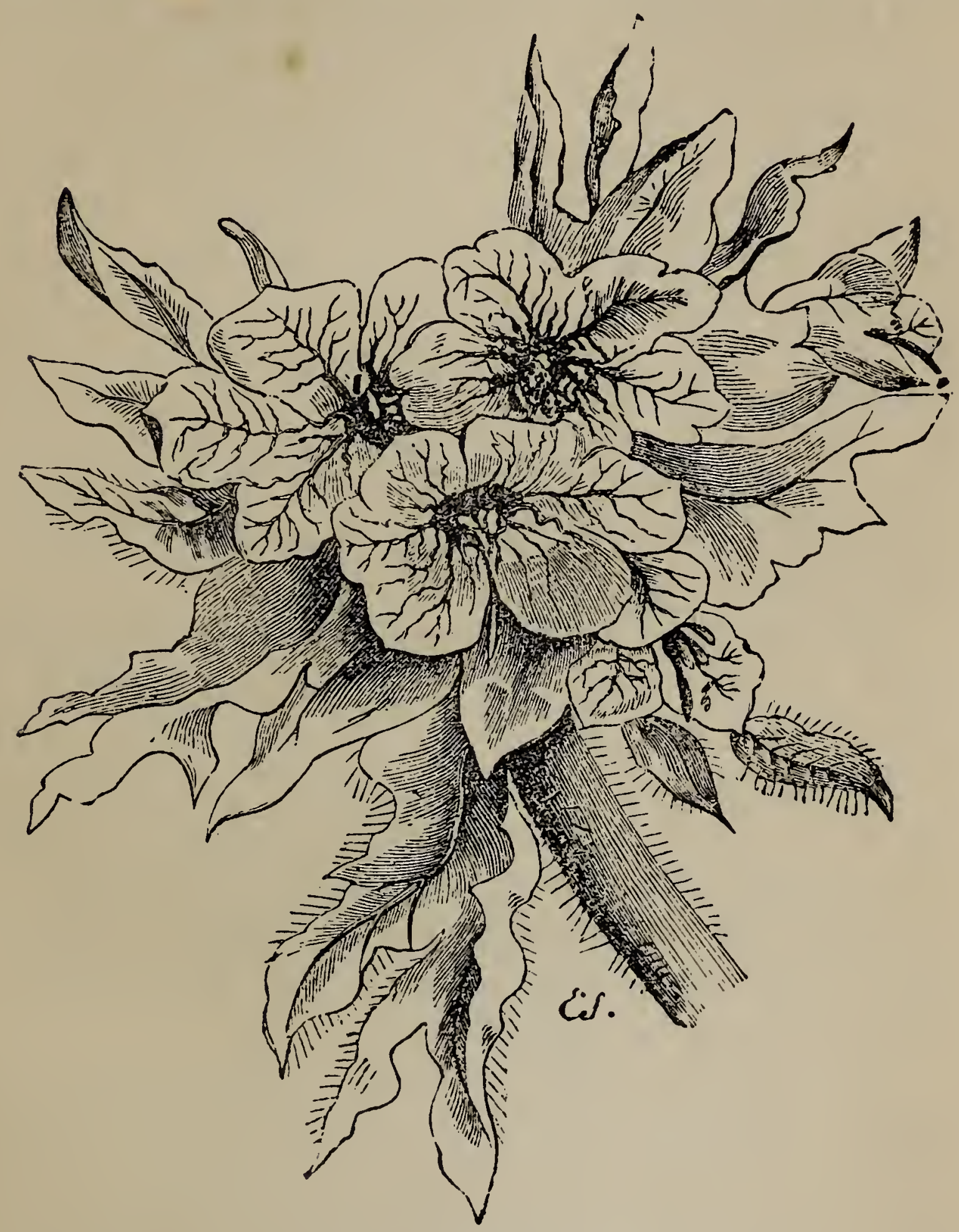

HYOSCYAMUS NIGER.

purple; but the smell of the whole plant is intolerably disagreeable. The extract of the leaves is a valuable narcotic medicine. 
Verbascum nigmum, Dark Mullein, is another handsome plant, which grows in and about Gunwalloe Churchyard. From a tuft of large downy leaves it sends up to the height of three or four feet a single stem bearing a vast number of bright yellow flowers with purple stamens. It occurs also, like the last, on other parts of the coast.

On the rocks adjoining Gunwalloe Church grows Statice binervosa, Sea Lavender (see next page), a pretty plant, with glaucous leaves and branched spikes of purplish blue flowers. After these have disappeared, the seeds tipped by the transparent membranous calyx long remain conspicuous, and retain their ornamental appearance for a considerable time after the flower-stalk has been gathered. S. Ameria, Sea-Thrift, is everywhere abundant.

The wet valley which runs up from Gunwalloe Cove contains a great many plants worthy of notice, and is particularly rich in Sedges; but these I must pass by, it being impossible to describe them without using technical terms. The botanist, however, will gladly turn aside to collect a few specimens of Galingale (Cyperus longus), which grows here as well as at Landewednack and Kennack.

Ranunculus Lingua, Great Spear-wort, the largest plant in the genus, grows to the height of three or four feet; its leaves are long, narrow, and sharp, and its handsome varnished yellow flowers are conspicuous from a considerable distance. Lysimachia wulgaris, Great Yellow Loosestrife, grows with it, and attains an equal height. Its flowers are numerous, and assume a some- 
what pyramidal mode of growth at the summit of the stem; in structure they approach closely to the Pimpernel.

Menyanthes trifoliata well merits its fantastic name of Buck-bean; its rose-coloured flowers

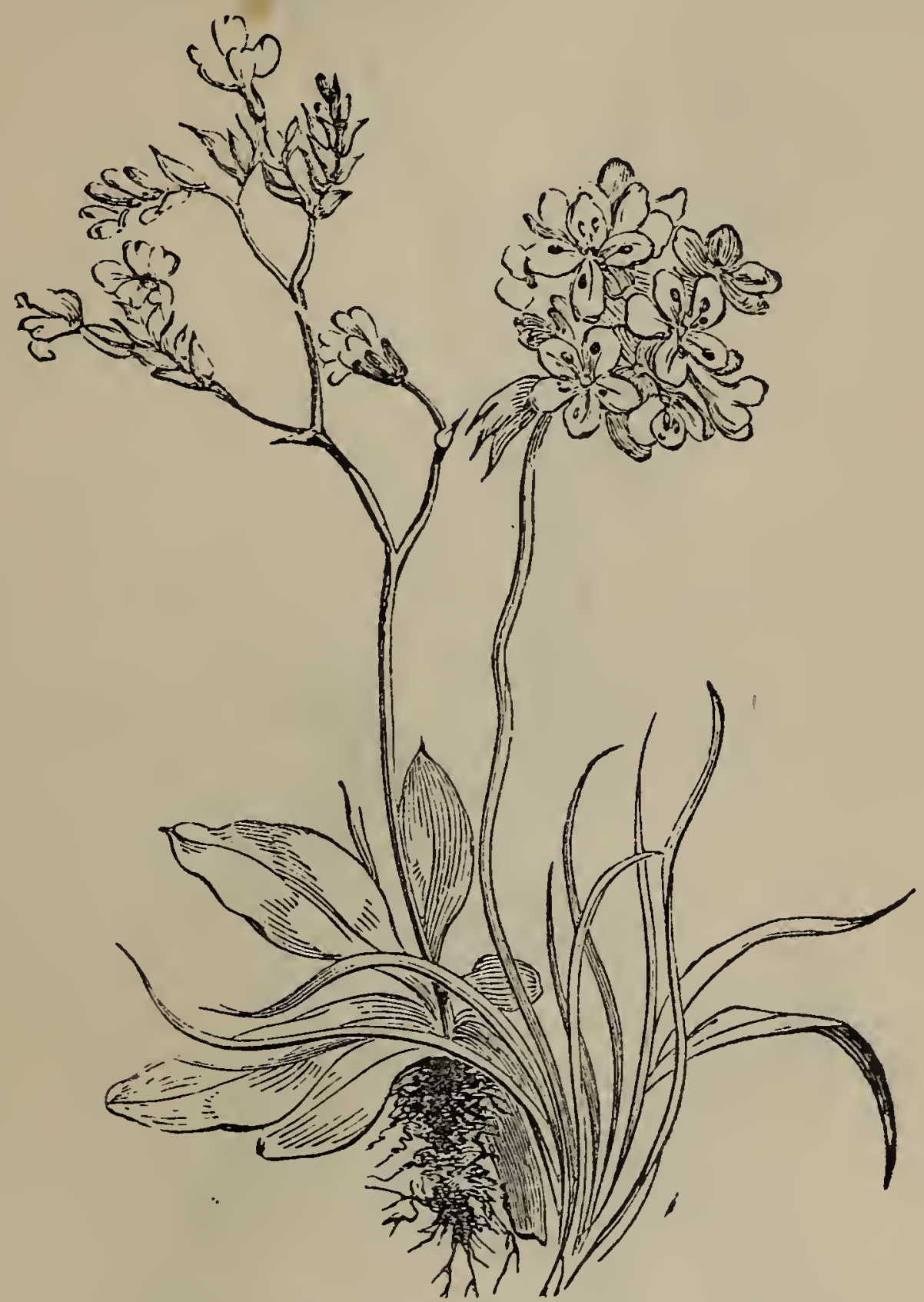

STATICE BINERVOSA, AND S. ARMERIA.

being tipped with red externally and beautifully fringed within with white filaments, it wears a very smart appearance. Its leaves closely resemble those of the Windsor Bean. Unfortunately, it loses most of its beauty in drying. 
Comamu palustre, Marsh Cinquefoil, will be at once distinguished by its large brownish purple

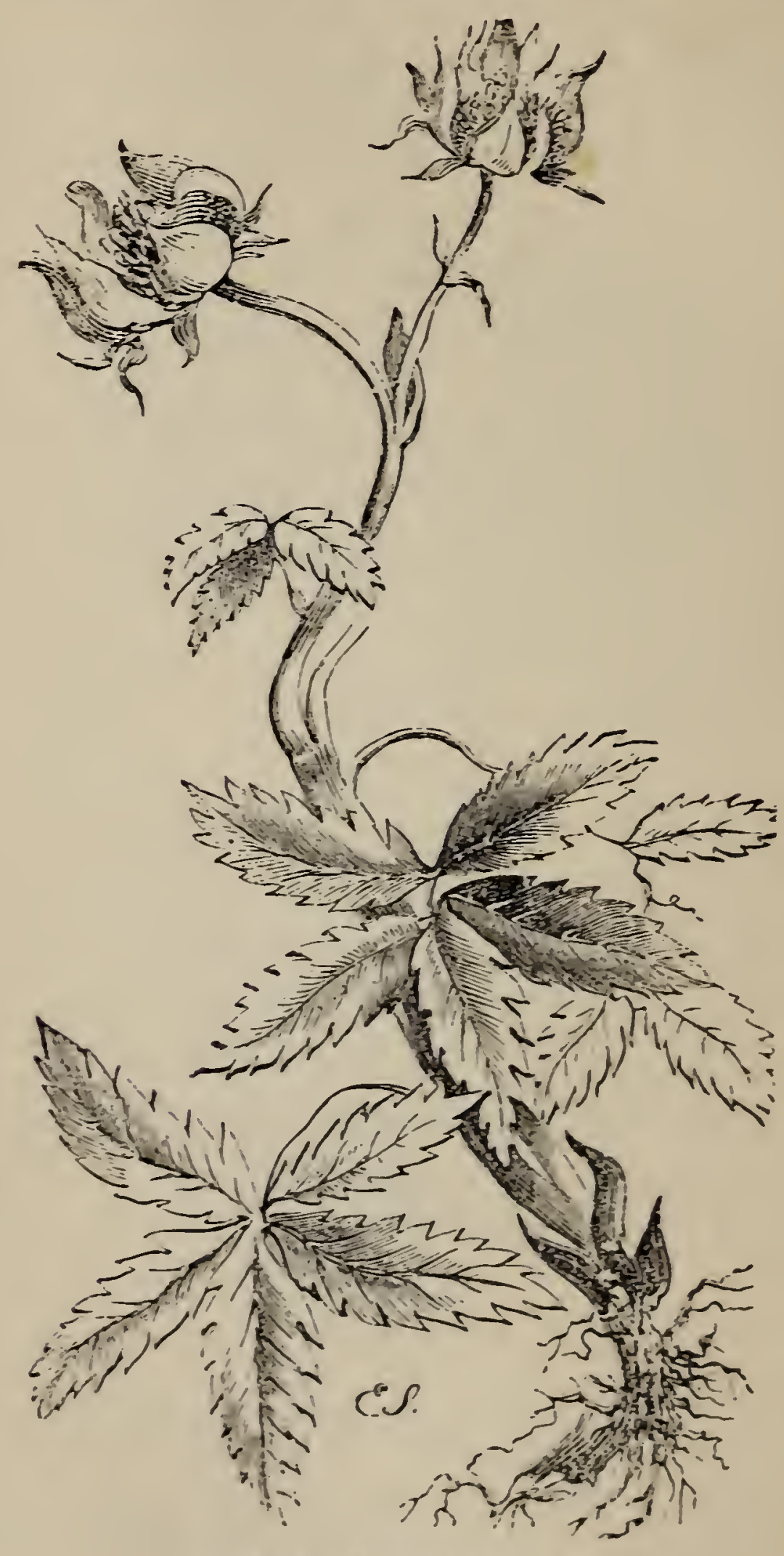

COMARUM PALUSTRE.

flowers and serrated leaves, which, as the name indicates, grow with five leaflets on a stalk. 
Poterium Sanguisorba, Common Salad-burnet, is plentiful on the left hand hedge as we ascend from Poljew to Mullion Church-town; so is Salvia Verbenaca, with its purple flowers and. irregularly shaped leaves.

I do not recollect that any plant of interest occurs between Gunwalloe and the cliffs south of Mullion. Here, however, we arrive at the serpentine formation, and fall in with several rarities. Erica ragans, Cornish Heath (see next page), is quite at home on this soil, and accompanies us for many miles, growing low and stunted when it encounters the sea-breeze, but in sheltered situations attaining a large size. Its flowers are either white, rose-coloured, or light purple.

Inula crithmoides, Golden Samphire, occurs sparingly on the rocks near Mullion. It may be distinguished from every other British plant by its fleshy narrow leaves, and large yellow radiated flowers.

Herniaria glabra, variety subciliata, Fringed Rupture-wort, which occurs plentifully in the cracks of the rocks, is a plant peculiar to the district. It has a tough stem which spreaa's on the ground, small leaves like those of wild thyme, and a profusion of small green flowers. It is remarkable only for its rarity.

Arenaria verna, variety Gerardi, Vernal Sandwort, is a small plant with numerous needle-like leaves, and star-like flowers of the most dazzling white. Though called vernal, its spring lasts from May till October, during all which time it is a conspicuous ornament to the cliffs. Sagina nodosa, Knotted Spurrey, frequently grows with 
it, and may be distinguished by its larger flowers, and by its smaller leaves, which are arranged around the stem in knots; it has also five pistils instead of three. The vernal Sandwort of the Lizard is said by some botanists to be distinct

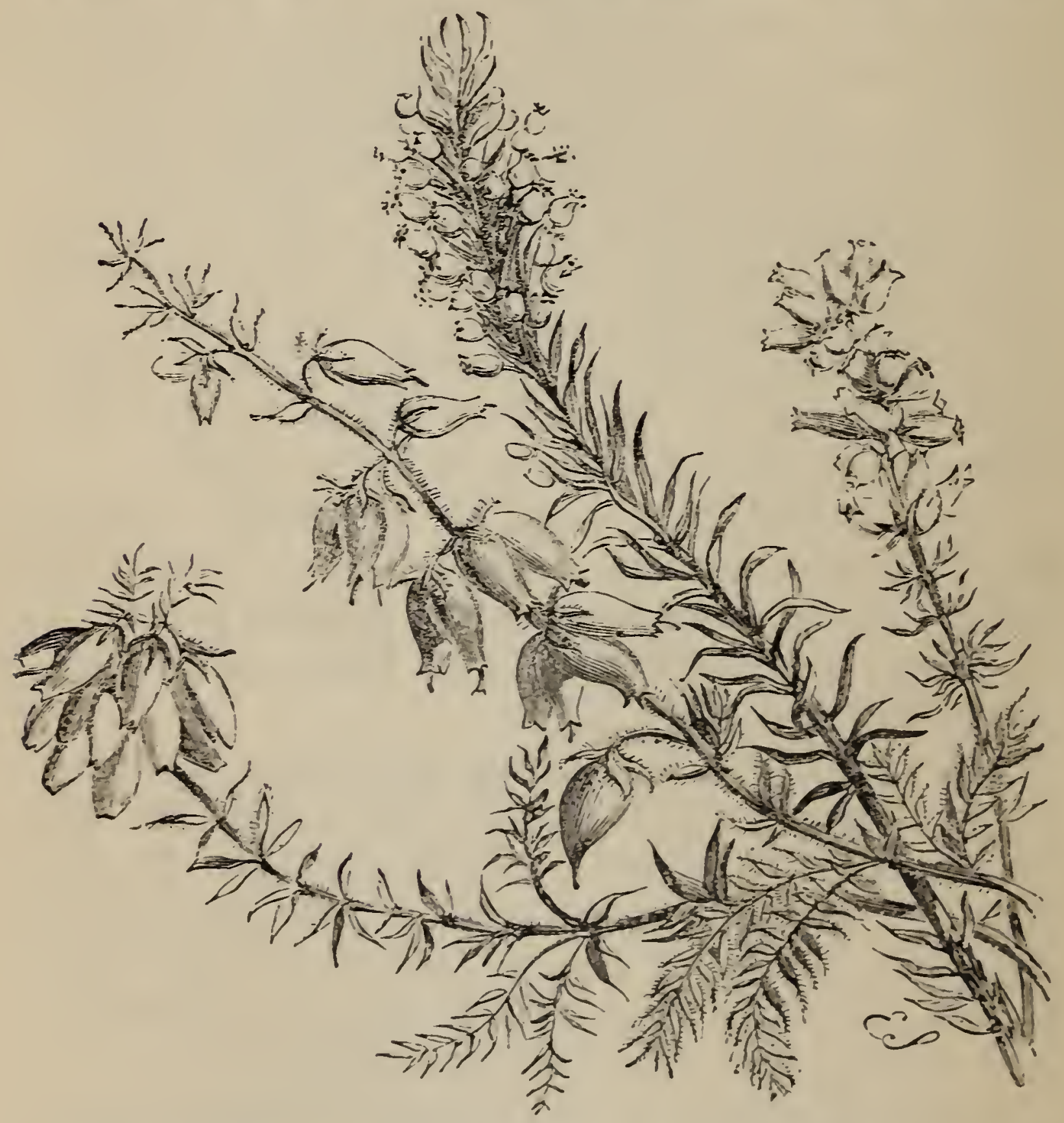

ERICA TETRALIX, E. CILIARIS, E. VAGANS, AND E. CINERIA.

from the northern plant which bears the same name.

Allium Schanoprasum $\beta$. Sibiricum, Chive Garlic, occurs at intervals, mostly where water has stood during the winter. Among the rocks 
under the Rill it attains a much larger size than on the open down. It may readily be distinguished by its large heads of rose-purple flowers,

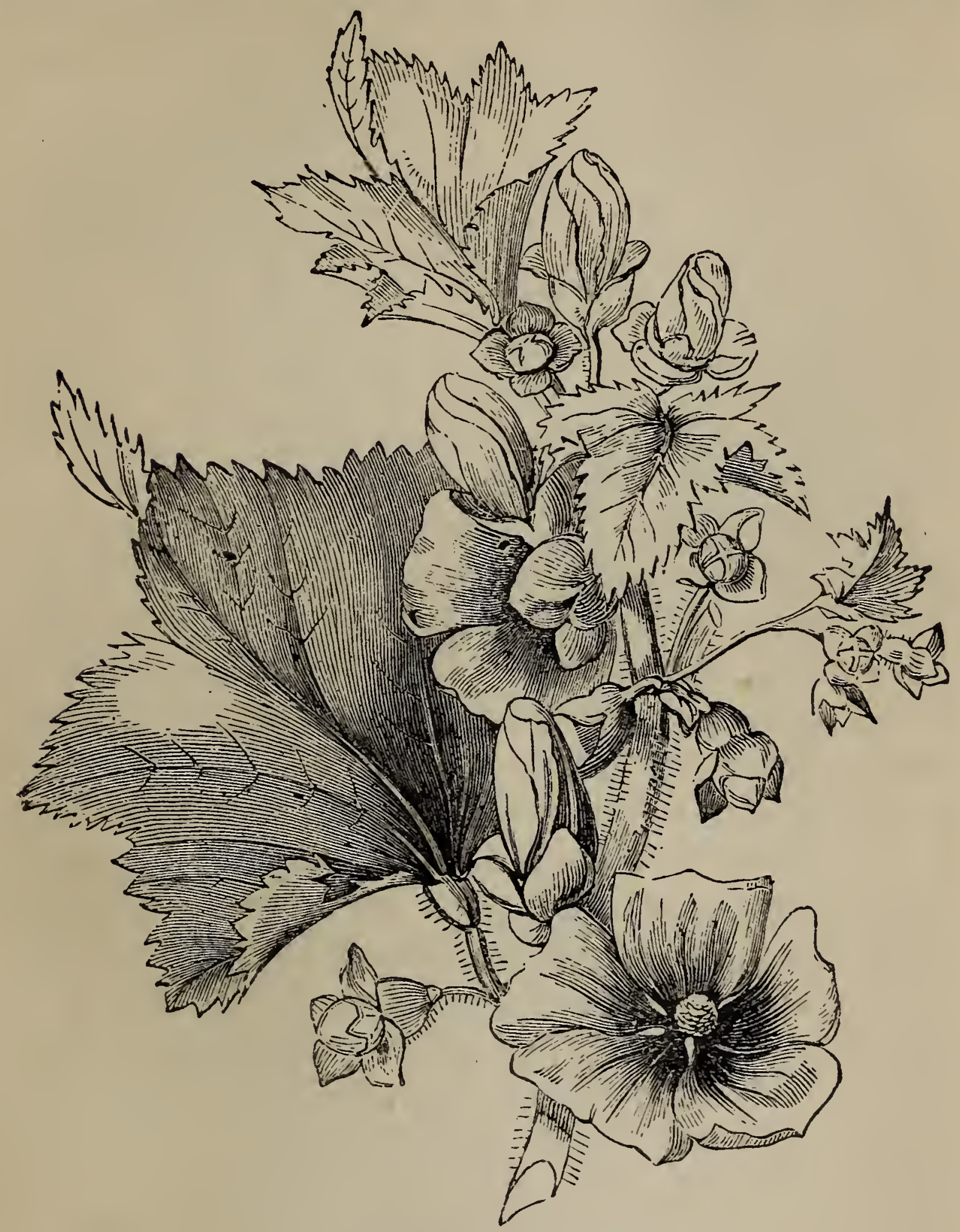

LAVA'TERA AREOREA.

which, when seen from a distance, are not unlike Sea-thrift. The sense of smelling may here help us to ascertain its identity. 
Lavatera arborea, Tree Mallow (see p. 239), a large and picturesque plant, chooses to perch itself on the insulated rocks all along the coast, in which situations it sends up its rigid, erect stem, in defiance of wind and storm. It varies in height from two to six feet or more.

Anthyllis vulneraria, variety Dillenii, Lady'sfingers (see next page), occurs in great quantities all along the coast. It differs from the ordinary form of the plant in being stunted in growth, and in having its flowers crimson, rose, flesh, creamcoloured or white. During the flowering season it ornaments the cliffs with a beautiful tapestry of variegated blossoms.

Bromus mollis, $\beta$. Lloydianus, Soft Downy Brome-grass, grows in great abundance along most parts of the coast, especially between Gue Graze and the Lizard. It is remarkable for its slender downy stems bare of leaves except below, and its dense soft heads of large florets. It varies in height from two inches to two feet, according as it grows in exposed or sheltered situations. An incident connected with the first notice of this plant may encourage the young botanist to look out for novelties, even in places which have been explored over and over again. Many years ago, before I had commenced the study of the grasses, being deterred from undertaking it by their number and complex structure, I happened to be walking round this coast, and seeing the plant in question near the Soap rock, I gathered a few specimens, with the intention of examining it, and finding out its name. After much time and labour had been expended, I succeeded in dis- 
covering to what genus it belonged, but was quite at a loss to decide its species. Several species approached very near, but the characters of no

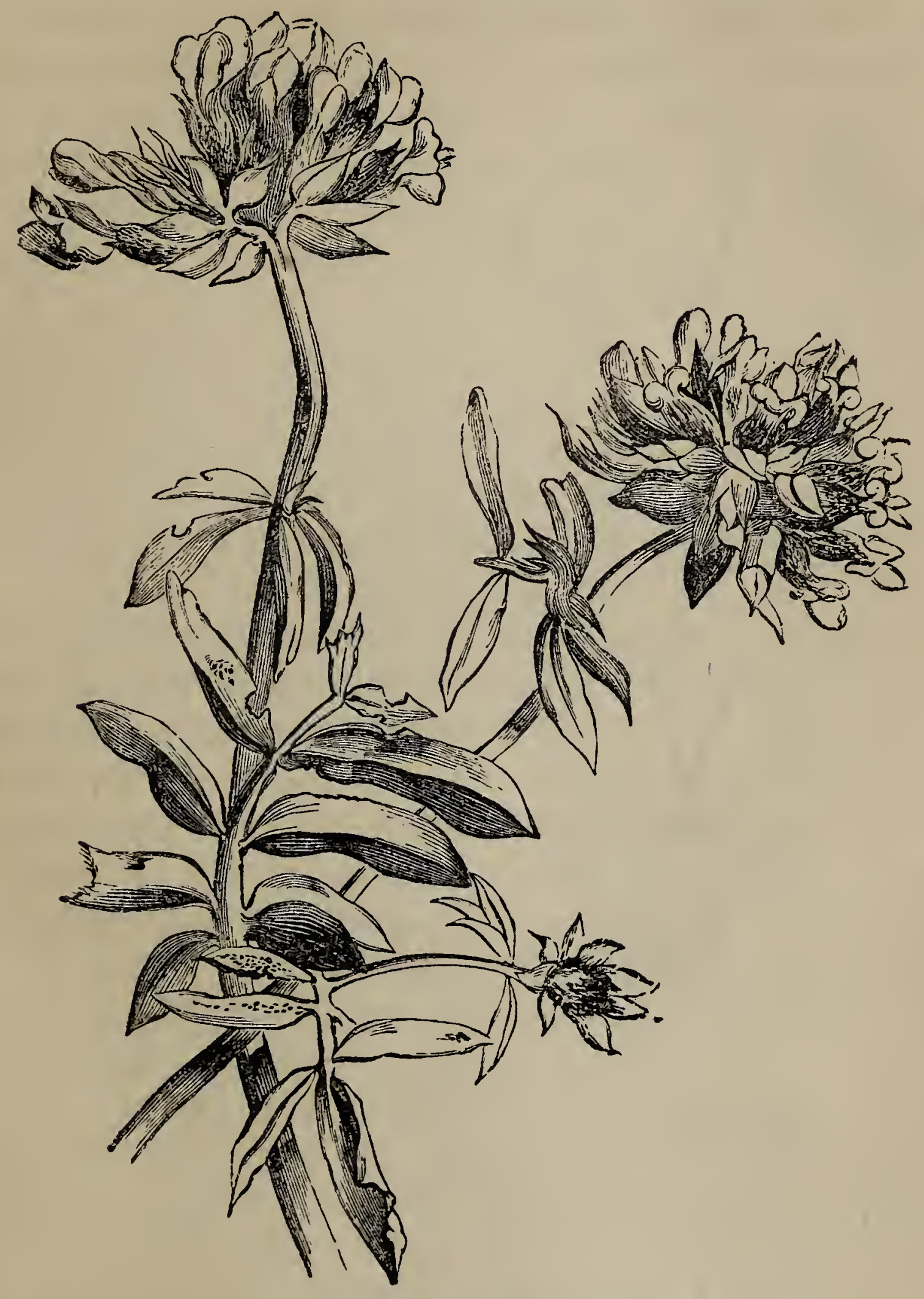

ANTHYLLIS VULNERARIA.

single one described appeared to me to accord exactly with those of my plant. I accordingly 
examined the plant as accurately as I could, and wrote a description, which I sent off by post, together with a dried specimen of the plant, to one of our first British botanists, whose address. I happened to know. In a few days I heard, to

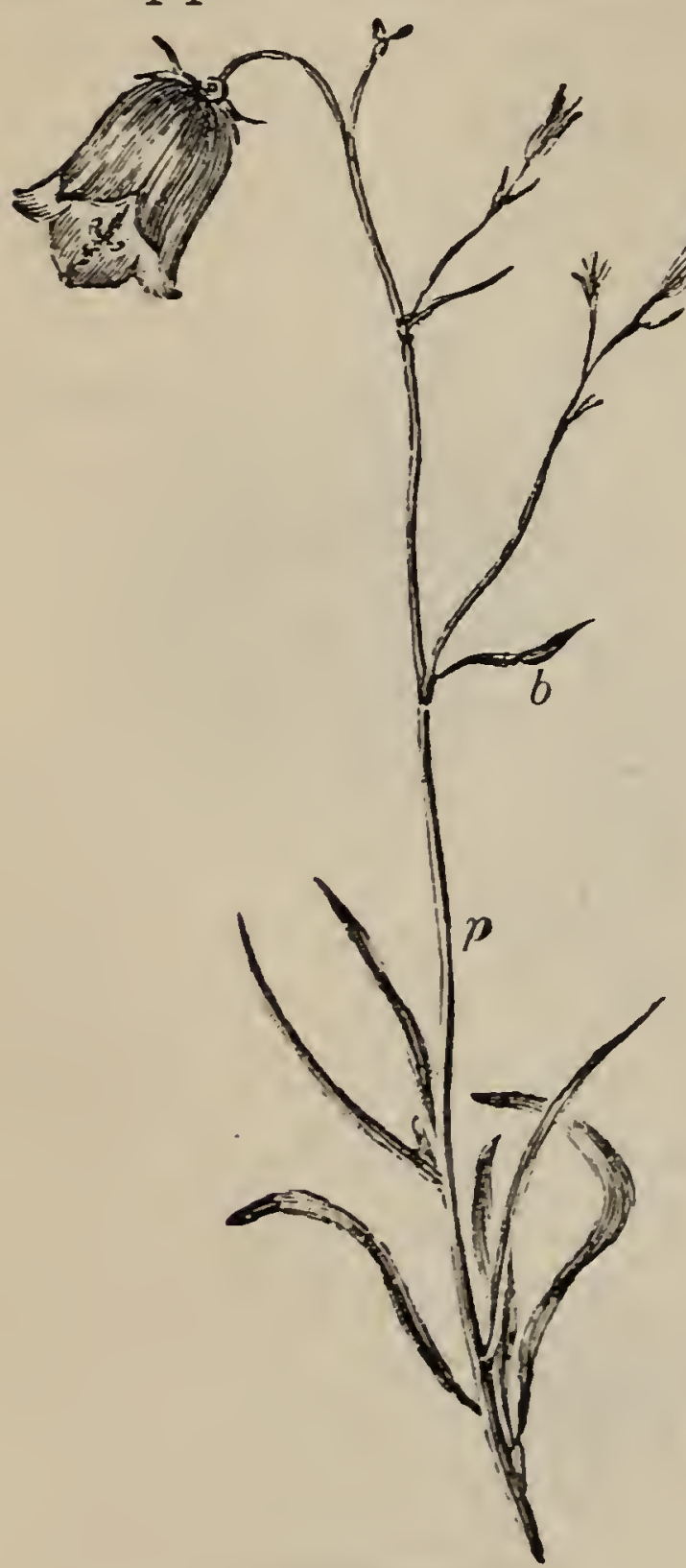

HARELELL. my great satisfaction, that my plant was a new variety, never having been observed previously to my finding it at the Soap Rock. Though it was then new to botanists, I have since remarked it in great abundance both here and on other parts. of the coast.

In several of the valleys. south-east of Gue Graze we meet with Campamila rotundifolia, the Harebell, a plant common enough in many places, but very rare in others.

At the head of Gue Graze valley, Junipems communis, variety prostrata, Dwarf Juniper, may be found in abundance, bearing in great profusion berries which are covered with a bloom like that of the plum.

Asparagus officinalis, Common Asparagus, grows in great abundance in the clefts of the rocks under the Rill, on the island at Kynance, to which it gives name, and in a ravine a fow 
hundred yards north-east of Cadgwith Cove. It is in all respects like the Asparagus of our gardens, and at thelast-mentioned place is treated as a culinary vegetable. Though always remarkable for its elegant mode of growth, in autumn it is particularly ornamental, owing to the contrast to the vegetation around it, afforded by its. brilliant yellow foliage and scarlet berries.

Among the rocks on the western side of Kynance valley grows Hypochoris maculata, Spotted Cat's-ear. It is conspicuous in June, with its large deep yellow flowers, somewhat like those of the Dandelion. Each plant bears a few broad, prostrate, hairy leaves, and rarely more than a single flower rising from the midst of them.

Neottia spiralis, Lady's-tresses, an orchideous plant about six inches high, with a row of small greenish-white fragrant flowers, arranged spirally round the stem, occurs in patches on many parts of the coast. It flowers late in autumn.

Cladium Mariscus, Twig-rush, abounds in the higher parts of the stream which runs through the same valley. It may well be distinguished by its long, sharp-edged, rigid leaves and canelike stems much branched above.

Sarothamnus scoparius, var. prostrata, Common Broom, may be met with a little way up the valley. It differs only from the common form by its prostrate growth and its branches spreading in a fan-like manner. It also occurs near the Lizard Lights.

Euphorbia amy'gdaloides, Wood Spurge, may be noticed among the brushwood near the above. 
All about this ravine grows in great luxuriance, Geranium sanguineum, Blood-red Crane'sbill, a bushy herbaceous plant, familiar in gardens, with deeply-divided leaves, and flowers as large as a half-crown. It is one of our most showy British plants.

On the downs above Kynance Cove Trigonella ormithopodioides, Bird's-foot Fenugreek, may be found in profusion.

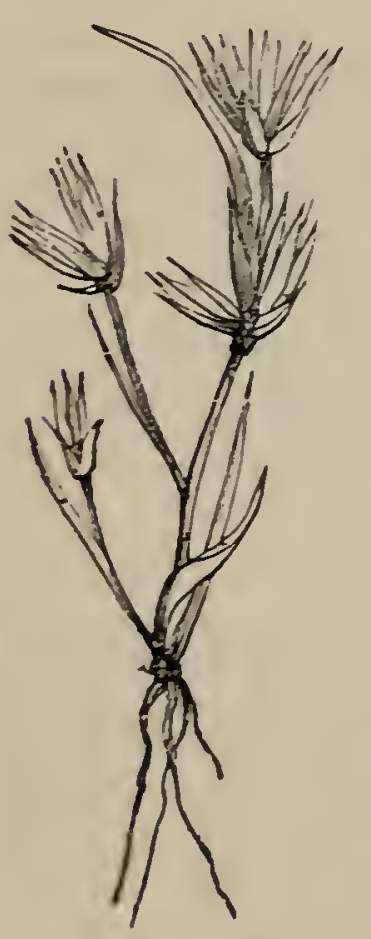

juxicis

PYGMÆUS.

In damp hollows a little beyond, the sharp-eyed botanist will be glad to find Juncuspygmaeus, Pigmy Rush, which varies in height from half an inch to two inches. It may be distinguished from Juncus buffonius, Toad Rush (which is very common here as elsewhere), by the thin, paperlike perianth, the segments of which are connivent when in fruit. It flowers in May, and early in June turns brown. This is the only habitat known for it in the United Kingdom. grows in gravelly or sandy places near the above, and occasionally mixed with it. It may be recognised by its dense heads of flowers. It seldom exceeds two inches in height. It is also found near the Land's End, and has long been known as a native of Jersey. It was discorered in Cornwall in 1872 .

Exacum filiforme, Least Gentianella (see next page), is a minute plant, with a branched wiry stem, and a few small yellow flowers which remain open only as long as the sun shines. It 
grows in several parts of the down, where water has stagnated during winter.

Spirea Filipendula, Common Dropwort, which the tourist is sure to observe in many places, may well be distinguished from $S$. Ulmaria, Meadow-sweet, by its deeply-cut leaves and rose-coloured flower-buds; its flowers are also destitute of fragrance. Another singular plant, which is also abundant here, is Sanguisorba officinalis, Burnet (sce next page), a tall plant with wiry stems and oblong heads of deep purplebrown flowers.

A sloping bank on the righthand side of Caerthillian valley, about a hundred yards from the sea, produces, I should think, more botanical rarities than any other spot of equal dimensions in Great Britain. Here are crowded together, in so small a space that I

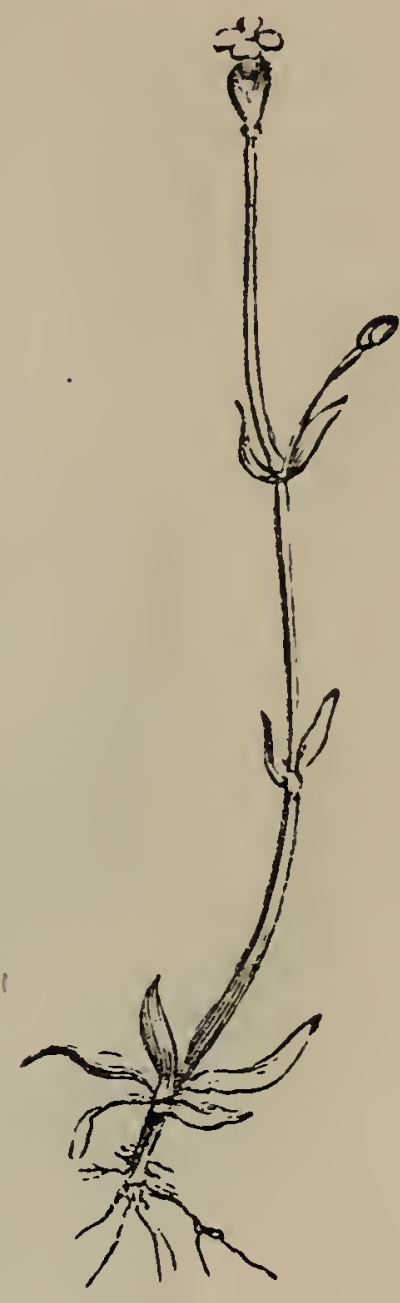

EXACUM FILIFORME. actually covered with my hat growing specimens of all together, Lotus hispidus, Trifolium Bocconi, T. Molinerii, and T.strictum. The first of these is far from common; the others grow nowhere else in Great Britain. T. Bocconi and T. Molinerii were first observed about ten years ago; the former may be distinguished by its terminal heads of flowers, which always grow in pairs; it occurs also in a hedge near Cadgwith, and on a rocky mound between that place and Poltesco. T.Molinerii occurs at intervals between this spot and 
Cadgwith flagstaff; it is easily detected by its large star-like heads of downy flowers, which, as the seeds begin to ripen, assume a remarkable

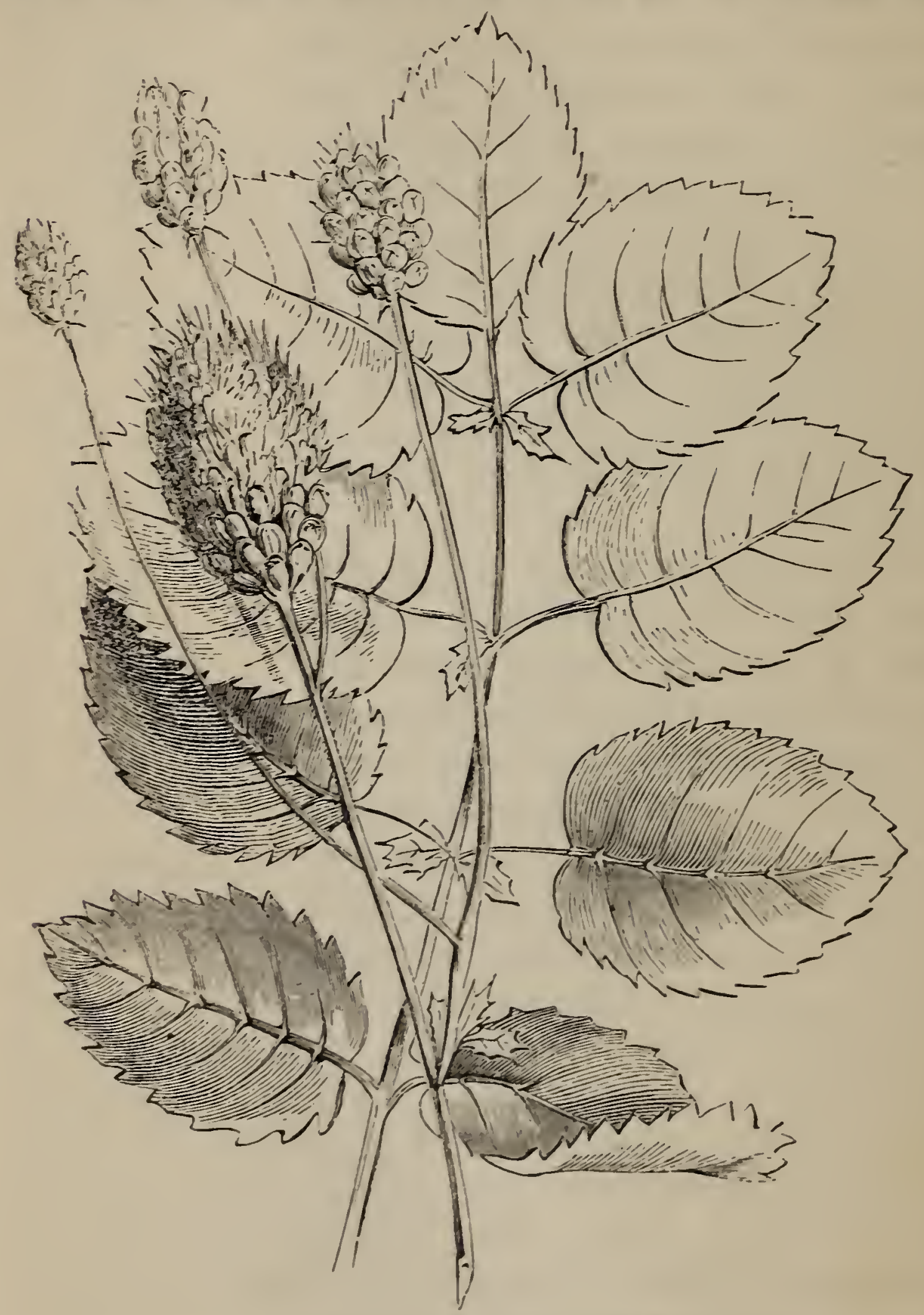

SANGUISORBA OFFICINALIS.

whitish huc. T. strictum I had the good fortune to discover in July, i 847 , here and near the 
Old Lizard Head. It is strongly marked by its erect habit, long, serrated leaflets, and globular rigid heads of flowers. It was previously known as a native of Jersey, but had not been noticed in Great Britain.

The fact that three species of Trefoil peculiar to the district should have been discovered growing together, has been thought so singular, that some botanists have entertained doubts whether they are really indigenous. I myself see no reason to doubt that their first introduction to the Lizard district was coeval with that of the rest of the vegetation on the cliffs. It should be remembered, that as the Lizard is the most southerly point in England, and its climate uniformly mild, we have good grounds for expecting to find plants properly belonging to the warmer sea-coasts of Europe, and such is the case with these three Trefoils; they are all found on the coast of the Mediterranean. It frequently happens, that plants which have been introduced at first accidentally into a new country, have taken to the soil and become quite naturalized. Thus I have found near Plymouth several plants unknown to our Flora, but indigenous to the opposite coast of France. As these all grew in the vicinity of a spot where vessels frequently discharge their ballast, it is natural to suppose that strange seeds were thus introduced, and had established themselves. Foreign plants are also sometimes found growing in arable land, having been imported along with foreign grain. At other times they appear in situations to which they may have easily escaped from gardens. A new character 
of vegetation has, of late years, clothed some parts of the shore of the Mediterranean, the strange plants being identical with those which

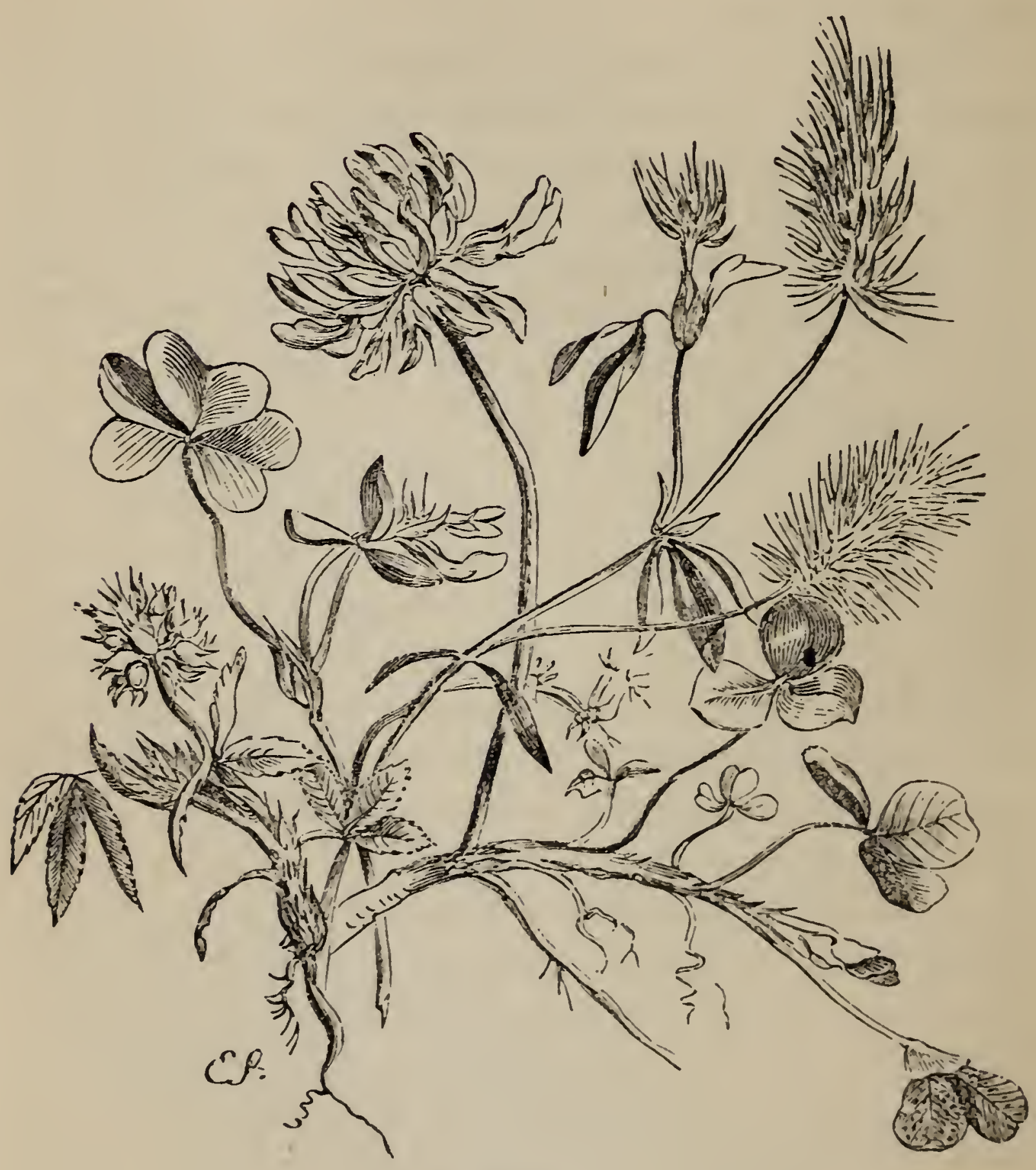

TREFOILS.

grow on the northern coast of Africa. The seeds of these, there is no doubt, have been brought over, entangled in the fleeces of African sheep, which are imported in large numbers. But, in 
the case of the Lizard plants, none of these causes is at all likely to have operated. The cliffs in the vicinity are precipitous, and no ballast thrown overboard or washed from a wreck could be carried thither. It is true that smugglers. formerly kept up a continual communication with France and the Channel Islands, but it would be absurd to suppose that smugglers were in any way accessory to the introduction of such worthless weeds, as they would think them. Nor can they have been brought over with foreign seeds, the small farmers in the neighbourhood caring little about improved varieties of agricultural plants. That they have not escaped from a garden is equallycertain; for no garden devoted to the cultivation of rare plants exists within many miles round. That they have only recently been observed bybotanists, may well be accounted. for by the reflection that visitors are rare and the coast very beautiful; hence it happens that the grander features of the scenery form the principal attraction; and moreover, as the cliffs are very wearisome to travel over, many parts have not been explored at all. Nor must the fact be lost sight of that the serpentine formation is a very uncommon one in England, and may be favourable to the growth of the plants in question; if this were not the case, we should perhaps find them in other situations. But after all, the simplest solution of the question is to assume at once that there was a time when Great Britain was a portion of the European Continent. The whole was then clothed by continuous zones of vegetation, which the subsequent formation of: 
the Channel interrupted, indeed, but did not destroy.

The Tamarisk-tree, Tamarix gallica, grows very luxuriantly near Landewednack Church, and at Cadgwith, but is evidently not indigenous.

Raphanus mavitimus, Sea-Radish, is very abundant on the cliffs from the Lizard to Kennack; it may be distinguished by its jointed pods, and large yellow cruciform flowers, which are of a paler colour than most of the plants belonging to the same natural order.

Among the rocks under the Hot Point, the beautiful fern, Aspleninm lanceolatimn, Lanceolate Spleenwort, attains a size much larger than I have ever seen it elsewhere. $A$. marimum, Sea Spleenwort, is common all along the coast; its favourite haunts are caves, the roofs of which are beyond the reach of the sea-water. In Ravens' Hugo it grows most luxuriantly, and within reach of the collector.

Near Kynance, on the Balk, near Cadgwith, and especially on the sandy cliffs at Kennack, we meet with a singular-looking plant, which in its young state resembles a shoot of Asparagus; when in perfection, it is a reddish-brown, scaly, viscid stem, with ringent or gaping flowers of nearly the same colour, but entirely destitute of leaves. On pulling it up we find that the stem terminates below in a solid scaly knob, with a few rootlets. This is Orobanche mbra, Red Broomrape, one of a genus of plants which are parasitic on the roots of various others, such as Broom, Furze, Clover, Ivy, Carrot, \&c. This species is found only on basaltic and other rocks 
which appear to be volcanic in their origin. I am inclined to think that it is parasitic on the roots of wild Thyme, but am by no means certain. It grows also on basaltic rocks at the Giant's Causeway and at Staffa.

Vicia lutea, Yellow Vetch, occurs on several parts of the cliff between the Balk and Cadgwith; its habit is like that of the common Vetch (Vicia sativa), but its flowers are solitary and yellow.

Polycarpum tetraphyllum, Four-leaved. Allseed, much resembles Radiola millegrana, figured on page 227, but is larger. It grows on banks near Cadgwith village.

In an orchard at Poltesco grows a singular species of Garlic, Allium Babingtoni, which reaches the height of six feet; but as it is found nowhere else in England, and here only in cultivated ground, it can scarcely claim to be considered a native.

Gastridium lendigerum, Nit-grass, a pretty silky grass, distinguished by the swollen base of its florets, especially when dried, also grows on waste ground about Poltesco ; and on the banks near the sea we find in abundance Iris fotidissima, Roast-beef plant, with its sword-like leaves, lead-coloured flowers, and scarlet seeds ; and Ruscus aculeatus, Butcher's-Broom (see next page), a low shrub with minute green flowers or large scarlet berries growing from the centre of its rigid spinous leaves.

Kennack Cove abounds in most of the sandplants already described; a new species of Salvia, S. clandestina, is also said to grow here, 
but I have never observed it. Orobanche mubre is very abundant; and among the heath and brambles on the eastern side, Thalictrum minus,

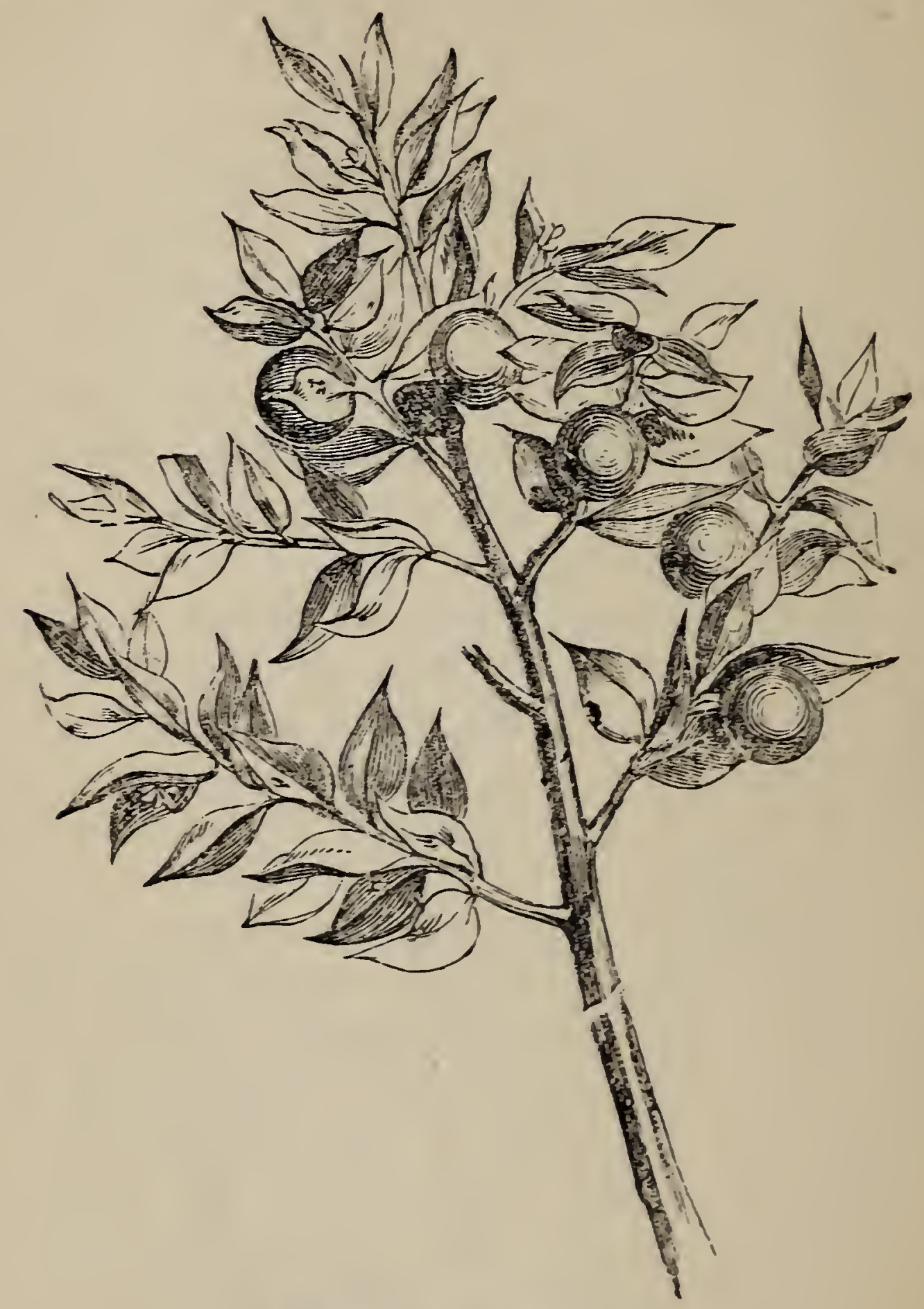

RUSCUS ACULEATUS.

Lesser Meadow Rue, is equally plentiful ; it may be detected by its elegant pendulous flowers, which are destitute of petals, but are nevertheless made conspicuous by their numerous long filaments and large yellow anthers; the leaves 
resemble in shape and colour those of the common Garden Rue.

Geranium striatum, Pencilled Geranium, grows on an orchard hedge near St. Ruan Rectory. Botanists do not consider it indigenous.

Illecebrum verticillatum, Whorled Knot-grass, an extremely rare plant, confined to the West of England, does not grow within the Lizard district, but may be met with in the valley above the village of Gweek, and in many marshy spots about Helston.

Other plants, more or less rare, occurring in the district are, Serratula tinctoria, var. monticola, which is received as a species by some continental botanists, frequent on the downs ; Schomus nigricans; Isolepis Savii; Juncus maritimus; Festuca elatior, near the brook which flows through Kynance valley: Alisma ranunculoides, common in pools on the downs: Pilularia globulifera, a rush-like ally of the ferns, common in similar localities; Koleria cristata, Crested AirGrass, with its spikes of silvery grey, on the coast between Pistol Meadow and Lizard Lights ; Gentiana campestris, in fields west of Kynance; and Anthemis nobilis, Chamomile, so abundant in many parts of the downs as to scent the air for furlongs, or even miles together.

Erodium cicutarium, Hemlock Stork's-bill, grows in sand on the Loe Bar, and in various similar situations along the coast.

Erodium maritimum, Sea Stork's-bill, is abundant at Mullion, Kynance, and the Lizard. It may be looked for on the stone fences locally termed 'hedges.' 
Erodium moschatum, Musky Stork's - Bill, is the rarest of the three. It is plentiful on hedges near Ruan Minor, and especially so in the lane near Cadgwith.

Borago officinalis, Common Borage, with its conspicuous blue and white flowers, will be noticed near Cadgwith and elsewhere.

Mentlua Pulegium is plentiful near the little village of Trethvas, near the Lizard.

Mentha sylvestris occurs in the brook at the head of Caerthillian Valley.

Mentha rotundifolia grows in profusion near the bridge at the village of Gweek.

Mentha viridis is quite naturalised, and apparently wild, near the village of Coverack.

Lotus corniculatus, var. tenuis, may be found in the sandy lane leading to Gunwalloe Church, also in fields near Poltesco.

For many important additions to the above catalogue I am indebted to an able and zealous. botanist, Mr. James Cunnack of Helston.

\section{APPENDIX II.}

\section{CATALOGUE OF BIRDS OBSERVED IN THE}

\section{LIZARD DISTRICT.}

THE Lizard district, from its extreme southern position, furnishes, as might be expected, an extended list of migratory birds, while its almost insulated character offers peculiar advantages for observing the habits of those among the marine birds which frequent cliffs and the open sea, 
rather than the sandy sea-shore and muddy estuaries.

The subjoined list, compiled, with much care and from authentic records, by Mr. F. V. Hill of Helston, will be perused with pleasure by all who take an interest in the fauna of the British Isles.

The woodcut, "The Biter Bit," is from a pho-

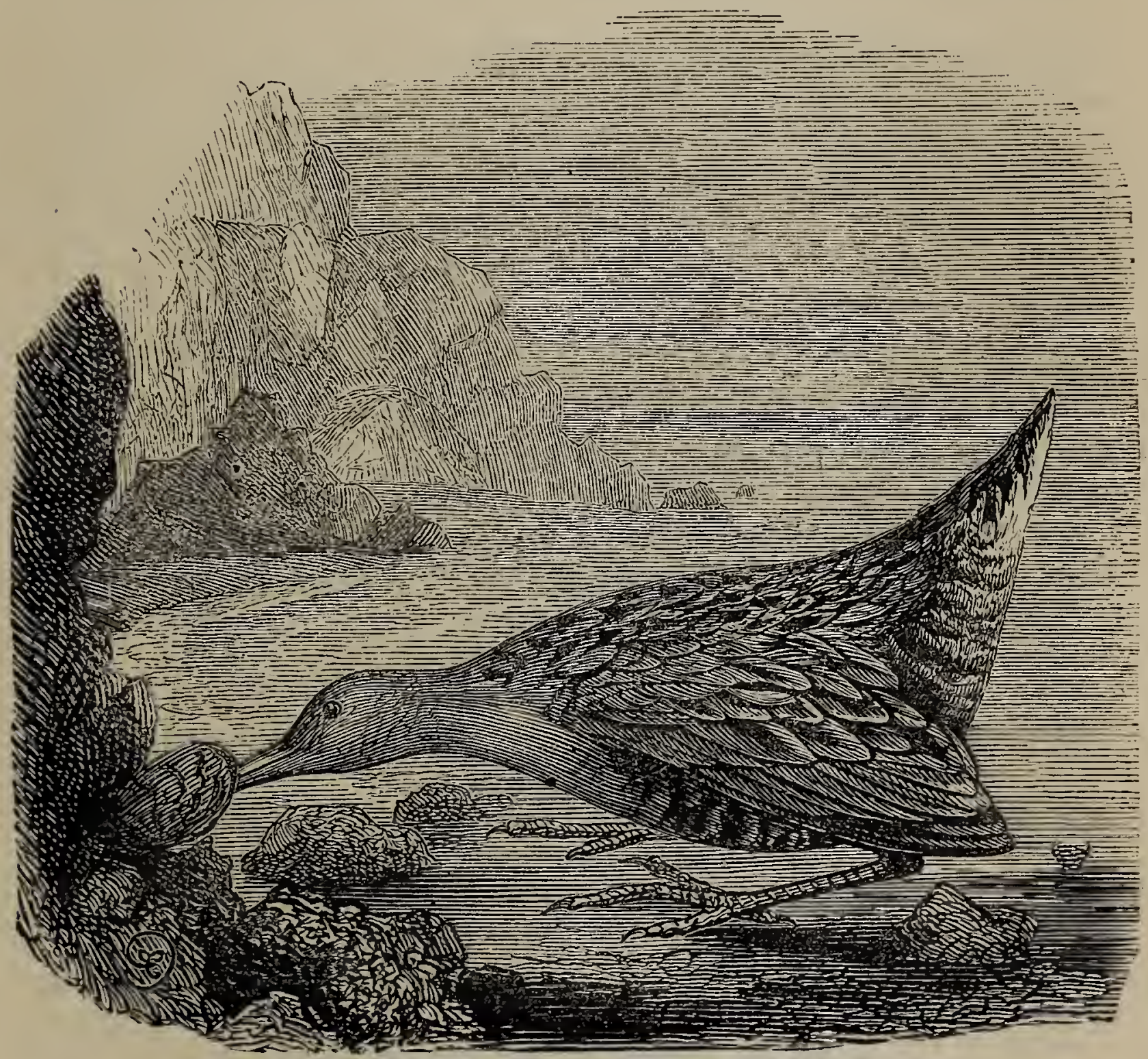

"THE BITER BIT."

tograph of a group in the museum of Mr. Hill, representing the capture of a water-hen by an oyster at Helford. The bird prowling about for food had fallen in with a partially-opened 
oyster, and without giving notice, had inserted its beak into the aperture, intending no doubt to make a meal of the dainty morsel. The oyster, however, resenting the intrusion, instantly closed its shell and held the bird fast until it died of exhaustion. Captive and captor were brought to Mr. Hill in the position in which they were found.

Gyr or Greenland Falcon (Falco Gy'falco). - Very rare -an adult specimen shot at Gwavas Farm, in Grade, in I830.

Peregrine Falcon (Falco peregrinzus). - Not rare-builds in Halzaphron Cliffs, near Gunwalloe, and at Trewavas Head. Three instances are known of its having followed sportsmen whilst snipe shooting on Goonhilly Downs, and carried off wounded birds.

Hoвву (Falco Subbuteo). - Rare-one seen at Gunwalloe in I 862.

Merlin (Falco AEsalon). - Rare-one shot at Gunwalloe in I 829, and another in I873 near Helston ; winter visitor.

Kestrel (Falco Tinnzunculus). - Very common.

Golden Eagle (Aquila Chrysä̈tos). - Only one specimen ever seen in this neighbourhood, which frequented the Trelowarren and Merthen Woods for some weelss in January and February, I859; it was frequently shot at, but escaped.

OSPREY (Pandion Haliaëtus).-()ccasional visitant. One was shot in the Helford River in 1838 , and another in the parish of St. Anthony, in Meneage, in 1840.

Sparrow Hawk (Accipiter Nisus). - Very common.

COMMON Buzzard (Buteo vulgaris). - Not uncommon.

Hen HARRIER (Circus cyanezis). - Rather rare-occasionally breeding on the borders of Goonhilly Downs.

Montagu's Harrier (Circus cinuaceus). - Common in Lizard district.

White OWL (Strix flammea). - Very common.

LitTle Owl (Noctua passerina).-One specimen shot in Constantine in November, I828, and another in St. Keverne in 1830 .

ShORT-EAREd OWl (Otus brachyotus). - Common - great numbers found by sportsmen shooting on Goonhilly Downs.

LONG-EARED OWL (Otus vullgaris).-Common.

TAwny OWL (Syminim Aluco). - Very common. 
Raven (Corvus Corax). - To be seen on the cliffs in pairs. CARRION CROW (Corvus Corone).-Very common.

HOODED CROW (Corvus Cornix).-Constantly seen on the banks of the Helford river in the autumn.

Rook (Corvus frugilegus). - Very common.

JACKDAw (Corvuls Monedula). - Very numerous, particularly on the cliffs.

MAGPIE (Pica caudata). - Great numbers to be seen every. where.

JAY (Garmulus Glandarius).-Common.

CORNish Chough (Fregilus Graculus). - A few to be seen on the cliffs; but they are so much sought after, and the eggs so much prized, that they will soon become extinct.

The Bohemian Waxwing (Bombycilla garrula).-Occasionally seen at uncertain intervals. In I 828 there were several shot in the neighbourhood of Helston.

GOLDEN ORIOLE (Oriolus Galbula). -A single specimen taken in a fishing-boat off Porthleven in 1827.

STARLING (Stumus vulgaris). - Great flocks make their appearance about October, and leave early in the spring. Not known to breed in the district.

ROSE-COLOURED PASTOR (Pastor rosencs).-Very rare-one killed near Helston in 1830 .

Spotied Flycatcher (Muscicapa grisola).-Common.

RED-BREASTED FlyCATCHER (Muscicapa parva).--A female specimen of this rare bird was shot, in 1863 , in Constantine, and sent to the British Museum. This species has not hitherto been recorded as found in Great Britain.

Missel Thrush (Turdus viscivornas). - Common.

Fieldfare (Turdus pilaris).-Dery large numbers arrive about the end of October.

SONG THRUSH (Turdus musicus).--Very common.

REDWING (Turdus iliacus). - Large flights come about the end of October.

RING OUSEL (Turdus torquatus).--Seldom seen-two specimens shot near Trevarno in I86I.

BLACKBIRD (Turdus Merula).-Very common.

SEDGE WAR BLER (Salicaria phragmitis). - Common-principally to be found in Poljew and Gunwalloe valleys.

BLACK-CAP WARBLER (Curruca atricapilla). - Not uncommon.

Common White-throat (Carruca cinerea).-Very common.

REDBREAST (Erythaca Rubecula).-Very common.

BLack Rfodstart (Phonicura Tithy's). - Two specimens 
killed-a male and female-on the cliffs in the Perran, near Marazion; they migrate to this district and remain throughout the winter. Another was killed at the Lizard.

REDSTART (Phcenicura ruticilla).-Rare.

WoOd WARBLER (Sylvia sylvicola).-Not uncommon.

Willow Wren (Sylvia Trochilus).-Abundant.

CHIFF-CHAFF (Sylvia Hippolaïs). - Very common.

GOLDEN-CRESTED WREN (Regulus cristatus). - Very common.

FIRE-CRESTED WREN (Regulus ignicapillus).--Rare.

WREN (Troglodytes vulgaris). - Very common.

Wheatear (Saxicola Enanthe).-Very common all along the coast.

Whinchat (Saxicola rubetra). - Very common.

Stonechat (Saxicola rubicola).-Very common.

HEDGE ACCENTOR (accentor modularis). - Very common.

PIEd Wagtail (Motacilla Yarrellii). - Very common.

White Wagtail (Motacilla alba).-Very rare. Yarrell mentions that he received one, and heard of two others that were obtained by Mr. J. J. Trathan, near Falmouth, in April, 1843.

Grey Wagtail (Motacilla Boarula).-Common-appearing in the autumn, generally about the time the woodcocks arrive.

Ray's Wagtail (Motacilla flava).-Rare.

Rock PIPIT (Anthus petrosus). - Very common.

Meadow PipIT (Anthus pratensis).-Very common.

SKYLARK (Alauda arvensis).-Very common.

CRESTEI) LARK (Alauda cristata).-Very rare-two killed on Marazion Green.

WOODI.ARK (Alauda arborea).-Common.

GREAT Tit (Parus major).-Common.

COLE Tit (Parus ater). - Common.

Blue Tit (Parus ceruleus).-Common.

Marsh Tit (Parus palustris). - Rather rare.

Longtail Tit (Parus caudatus).-Common.

Yellow Bunting (Emberiza Citrinella).-Very common.

Common Bunting (Emberiza Miliaria).-Common.

Black-headed Bunting (Emberiza Schaniclus).-Rare.

Cirl Bunting (Emberiza Cirlus).-Rare.

Snow Bunting (Plectrophanes nivalis). -Observed in most autumns.

Common Crossbill (Loxia curvirostra)-Several shot near Helston in 1829.

BULlFINCH (Pyrrhula vulgaris)-Very common.

HAWFINCH (Coccothraustes inlgaris). - In IS29 several were shot near Helston. 
GREENFINCH (Coccothraustes chloris).-Very common. House SPARRow (Passer domesticus)-Very common.

CHAFFINCH (Fringilla crelebs).--Very common.

BRAMBLING (Fringilla Montifringilla)-In severe winters.

LINNE'T (Linota cannabina). - Common.

SISKIN (Carduelis Spinus).--Rare.

Common Redpole (Linota Linaria). - Not rare.

GoLdFINCH (Carduclis elegans).-Very common.

MeAli RedPole (Linota canescens). - Rare.

Cuckoo (Cuculus canomis).-Common.

GREEN WOODPECKER (Picus viridis). -Not uncommon.

Lesser Spotted WoOdPecker (Picus minor).-Occasional.

WRYNECK ( Yunx Torquilla).-Dery rare.

Nuthatch (Sitta Europaa). - Very rare.

Creeper (Certhia familiaris).-Common.

Hoopoe (Upupa Epops). - Several have been taken-one shot at Grade in 1830, another in Landewednack in 1863.

BeE EA'Ter (Merops Apiaster). - In I824 twelve were seen close to Helston, and eleven were shot.

Kingfisher (Alcedo Ispida).-Common.

SWALLOW (Hirundo rustica).-Common.

MaRTin (Hinundo urbica).-Common.

SAND MARTIN (Hirundo riparia).-Common.

SwifT (Cypselus Apus).-Common.

White-BELlied SWift (Cypselus alpinus). - One specimen taken in Mylor.

GOA'T-SUCKER (Caprimulgus Europaus).-Common.

Woodpigeon (Columba Palumbus). - Very common.

TURTle Dove (Columba Turtur).-Occasionally met with in spring.

PARTRIDGE (Perdix cinerea).-Common.

QUAIL (Coturnix vulgaris).-Occasionally met with.

GREAT BUSTARD (Otis tarda). - The only specimen procured in this district was a female, which was shot, in February, I 843, in a turnip-field belonging to Joseph Lyle, Esq., of Bonython, where it had been observed for several days.

Lit'Tle Bustard (Otis Tetrax). -One was shot, about the year I830, on the Lizard Downs.

Great Plover (Edicnemus crepitans).-Occasionally met with in winter.

SANDERLING (Calidris arenaria).-Very common.

OYSTER-CATCHER (Hamatopus ostraleguls). - Occasionally to be seen along the coast.

Machetes Pugnax (Ruff).-Very rare. 
Golden Plover (Charalrius pluvialis).-Common, particularly on Goonhilly Downs.

DOTTREL (Charadrizes Morinellus). - Occasionally in spring and autumn.

RINGed Plover (Charadrius hiaticula).-Common.

Grey Plover (Squatarola cinerea).-Common.

LAPWING (Vanellus cristatus). - Very common.

TURNstone (Strepsilas interpres).-Occasionally to be seen.

Common Heron (Ardea cinerea).-Common.

COMmon BITTERN (Botaurus stellaris).-Several specimens have been killed.

Squacco Heron (Ardea comata). - Very rare-five specimens were shot at Trevenwith, in St. Keverne, in May, I849.

LitTle BitTern (Botaumus minutus). - Very rare-male killed in Newham Moors, near Helston, in 1838, and a female killed there in I84I. A female at Coverack 1867.

Night Heron (Nycticorax Gardeni). - Rare - two were killed in 1837, one in Cury, and one in Crowan. In April, I850, two specimens were shot, male and female, at Gunwalloe: the male is a remarkably handsome specimen, and has the unusual number of eight occipital feathers.

PURPle Heron (Ardea purpurea). - A very rare visitorone specimen only on record.

Spoonbill (Platalea Leucorodia). - Very rare-one was shot in Mawgan in 1859, and another in the Loe Pool in March, r865.

CORLEW (Numenius arquata).-Common.

Whimbrel (Numenizus phaopus). - Not rare-two specimens shot near Helston, in 1863 .

CURLEW SANDPIPER (Tringa subarquata).-Common.

Dunlin (Tringa variabilis).-Common.

PURPle SandPIPER (Tringa maritima). - Not common.

TRINGA SCHINZII (Schinz's Sandpiper).-One specimen at the Lizard.

Temminck's Stint (Tringa Temminckii).-Very rare.

LitTle Stint (Tringa minuta). - Very rare.

KNot (Tringa Canutus). -Common.

Common Redshank (Totanus Calidris). - To be seen occasionally.

Green SANDPIPER (Totanus ochropus).-Rare.

COMMON SandPIPER (Totanus hypoleucos).-Common.

Greenshank (Totanus Glottis). - Common.

BAR-TAILEd Godwit (Limosa rufa).-Common.

Black-Tailed Godwit (Limosa melanura).-Occasional.

Woodcock (Scolopax Rusticola). - Arrives in large flights about the end of Ostober. 
Common Snipe (Scolopax Gallinago). - Very abundant.

JACK SNIPE (Scolopax Gallinula). - Very common.

GREAT SNIPE (Scolopax major). - Very rare-two or three specimens have been killed in Constantine; and in 1862 one was killed at Mullion.

WATER RAIL (Rallus aquaticus). - Very numerous.

I.ANDRAIL (Crex pratensis).-Plentiful.

SpotTed CRAKE (Crex Porzana).-Rare.

MOORHEN (Gallinula chloropus).-Common.

Coot (Fulica atra).-Common.

Grey Phalarope (Phalaropus lobaties). - To be occasionally met with.

RED Lobefoot (Phalaropus hyperboreus.)-Very rare-one shot in Helford river.

GREAT-CRESTEd GRebe (Podicepscristatus). - Not uncommon.

EARED GREBE (Podiceps auritus).-Rare-one shot in the Loe Pool about twenty years since ; another in summer plumage, at Helford about seven years ago.

Little Grebe (Podiceps minor).-Common.

SANDWICH TERN (Sterna Boysii).-Rare-several have been taken.

Roseate TERn (Sterna Dougallii). - Very rare-four or five have been killed at Helford.

COMmon TERn (Sterna Himando).-Common.

LESSER TERN (Sterna mimuta).-To be seen occasionallyone killed at Gunwalloe, in October, 1852.

HERRING GULL (Lanes argentatus). - Very numerous all along the coast, and large numbers build at Mullion and Kynance.

GREAT BLACK-BACKED GULL (Larus marinus).-Occasional.

LESSER BlaCK-BACKed Gull (Lanis fuscues).-Common.

COMMON Gull (Larus canus).-Very numerous.

Kittiwake Gull (Larus tridactylus).-Common.

LitTle Gull (Larus minutus).-Rare.

BLACK-HEADED GULL (Lanes ridibundus). - In winter and spring.

Common Skua (Lestris Cataractes). -Often to be met with.

RICHARDSON'S SKUA (Lestris Richardsonii). - Rare-one killed at the Lizard, in October, $185 \mathrm{I}$.

Great Shearwater (Puffinus major).-Occasionally seen.

Manx Shearwater (Puifinus Anglorum). - Rare.

Fork-TAILED Petrel (Thalassidroma Leachii).-Very rare -one specimen was found on the banks of the Loe Pool, in December, I856.

Storm PeTrel (Thalassidroma pelagica). - Occasionally to be met with. 
Grey LAG GoOse (Anser ferus). - Only seen during very hard winters.

BerNicle Goose (Anser leucopsis). - Not uncommon in severe winters.

BRENT (Anser torquatus). - Not rare.

Egyptian Goose (Anser Egyptiacus). - One specimen was shot in the Loe Pool, in I849.

Hooper Swax (Cyonus fems). - Very rare-only seen during very severe winters. One was shot in the Loe Pool in 1826.

Common Sheldrake (Tadoma Vulpanser). - Rare.

Wild Duck (Anas Boschas). - Plentiful.

GADWALL (Anas strepera).-Rare.

PIN-TAIL DUCK (Anas acuta).-Rare.

Widgeon (Aras Penelope). - Very numerous.

Bimaculated Duck (Anas glocitans). - Very rare.

Shoteller (Anas Clypeata).-Occasionally seen.

GARGANey (Anas Querquedula).-Rare.

TEAL (Anas Crecca). - Common.

Commox Scoter (Oidemia nigra). - Not uncommon.

LoNG-TAILED DUCK (Fuligula glacialis).-Rare.

GOLDEx Eye (Fuligula clangula). - Not uncommon.

POCHARD (Fuligula ferina). - Not uncommon.

Tufted Duck (Fuligula cristata).-Rather scarce.

Velvet Scoter (Oidemia fusca). - Sometimes seen.

SCAUP Duck (Fuligula Marila). - Not very rare.

Goosander (Mergus Merganser-). - Often seen in the Helford river.

Red-breasted Mergaxser (Mergus Serralor).-Occasionally seen.

SMEw (Mergus albellus).-Rare.

Cormorait (Phalacrocorax Carbo). - Very numerous.

SHAG (Phalacrocorax Graculus). - Very common.

GAXxet (Sulu alba).-O Often seen on the coast when pilchards make their appearance; does not breed with us.

Great Northerx Diver (Colymbus glacialis).-Rarefine specimen obtained near Pra Sands, in Breage, a few years since.

Red-throated Diver (Colymbus septentrionalis). - Very rare-one killed in Helford river a few years since.

Common Guillemot (Uria Troile).-Very numerous.

Little Auk (Mergulus melanolcucos). - Very rare-specimen captured in Wendron a few years since, after a very heavy gale.

PufFin (Fratercula arctica).-Common at Mullion.

Razor-bill (Alca Torda). - Numerous along the coast. 
GEOLOGY.

\section{APPENDIX III.}

\section{GEOLOGY OF THE LIZARD DISTRIC'T.}

To the geologist the Lizard district affords a rare opportunity of examining the magnesian rocks, hornblende, serpentine, diallage, and talc-slate. The prevailing notion is that serpentine predominates, but this is not the case, hornblende, as far as can be ascertained, forms the foundation of the whole district, and on it the other magnesian rocks rest.

No attempt will be made here to enter into a dissertation on the mineralogical or geological condition of the district ; but simply to point out in succession to the tourist, who perhaps is limited by time, those points on the coast which best illustrate the geological features of the whole.

The reader, then, is supposed to have started from Helston, and to have proceeded through Gunwalloe and Poljew to Polurrian Cove. There the argillaceous slates terminate, and hornblende is first seen at low water in the rocks running into the sea. Proceeding thence to Mullion, he will come to the association of serpentine with hornblende. Between Mullion and Gue Graze Cove the serpentine is intersected by steatitic veins in various places. In the cove itself may be seen the old workings, where it was formerly quarried for the purpose of making 
porcelain. Going on to Kynance Cove, he will observe a well-developed intersection of the serpentine by a granitic vein or dyke running across the cove and over the top of the entrance to the cavern called the Drawing-room. Both here and in the cove it is readily distinguished by its light flesh-colour. At Polpeer Cove, near the Lizard, may be seen the combination of the talcomicaceous slate and hornblende. Passing on beyond Landewednack Cove, about half-way to Polbera Cove, the tourist will observe a welldeveloped example of serpentine overlying a bed of granitic and quartzose rock; this is remarkable as a formation belonging to different epochs, as the supposed serpentine rests on a bed of detrital matter, which, in its turn, rests on a more ancient, apparently water-worn, formation, This interesting spot can only be examined by landing from a boat, in doing which no difficulty will be found in ordinary weather. For the illustration of this remarkable junction I am indebted to Mr. Hart, whose studio near the Lizard Lights the tourist will find it well worth his while to visit. At the same time Polbera Cove should be visited, a little further on. This is accessible at low water only. There is a most remarkable and easily accessible cavern in which serpentine and diallage appear strangely intermixed. Proceeding further still, in a boat, we reach through a tunnelled rock the remarkable roofless cavern called the "Fryingpan," well worthy of examination, as interesting examples of the junction of hornblende and serpentine may be observed there. A similar combination occurs on the westward side of Cadg- 
GEOLOGY.

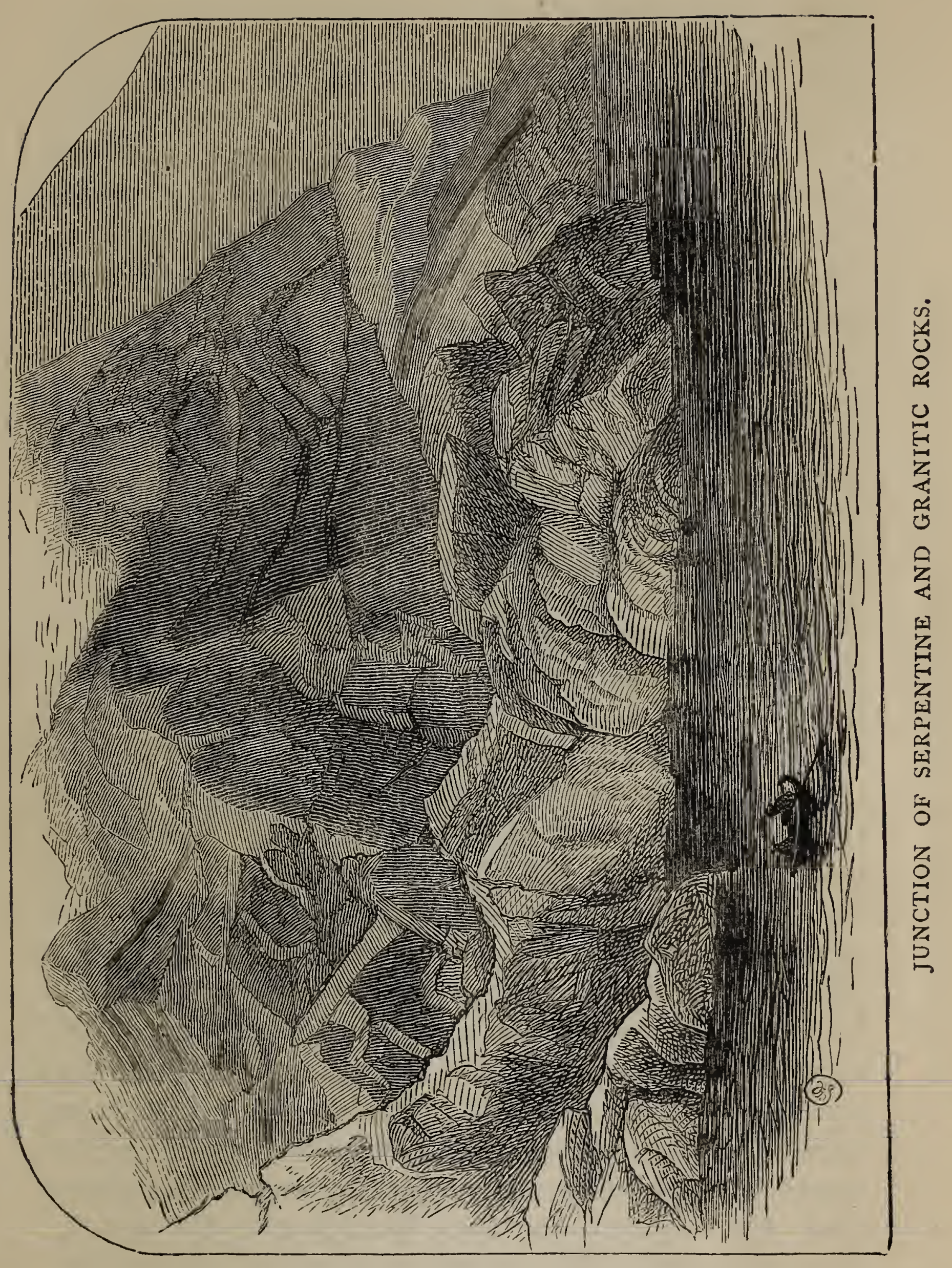


with Cove, while at the eastern side hornblende slate occurs well defined. Further on, at the eastern side of the Flag-staff quarry, serpentine may be observed overlying the hornblende, with a band between them of granite singularly alternated in layers with hornblende. Still further to the east is a landslip, called Killdown, on the beach below which may be found large, well-defined crystals of diallage and other magnesian rocks. Yet further to the east is Caerleon Cove, on the western side of which is a clear and well-defined lode of greenstone; and if the tourist will take the trouble to return westward, under cliff for about a quarter of a mile, he will fall in with several granitic cross courses well worthy of observation. In one of these will be found nodules of green quartz, and in the immediate neighbourhood specimens of jasper. Retracing his steps to Caerleon, and following the coast eastward, he will arrive at Kennack Cove. On the eastern side of the rocks extending out into the sea are several compact veins of greenstone running through the serpentine. In this neighbourhood occur specimens of rough and compact asbestos, some of a green colour, some dirty brown or (rarely) white. About a mile and a half beyond this cove the Cargloose rocks are well worthy of examination. These are the outlying point of a large deposit of diallage combined, or varied, with serpentine. There are many other spots worthy of investigation between this place and the Nare-as the Blackhead, Coverack, Porthalla, \&c. Whichever of them be visited, the tourist is recommended to arrange his ex- 
cursion so as to be on the ground about two hours before low water. The lowest tides occur two or three days after new and full moon, about noon, and are from three-quarters of an hour to one hour later every day.

The reader needs scarcely to be told that no attempt is made here to theorize on either the mineralogical or geological formation of the dis-
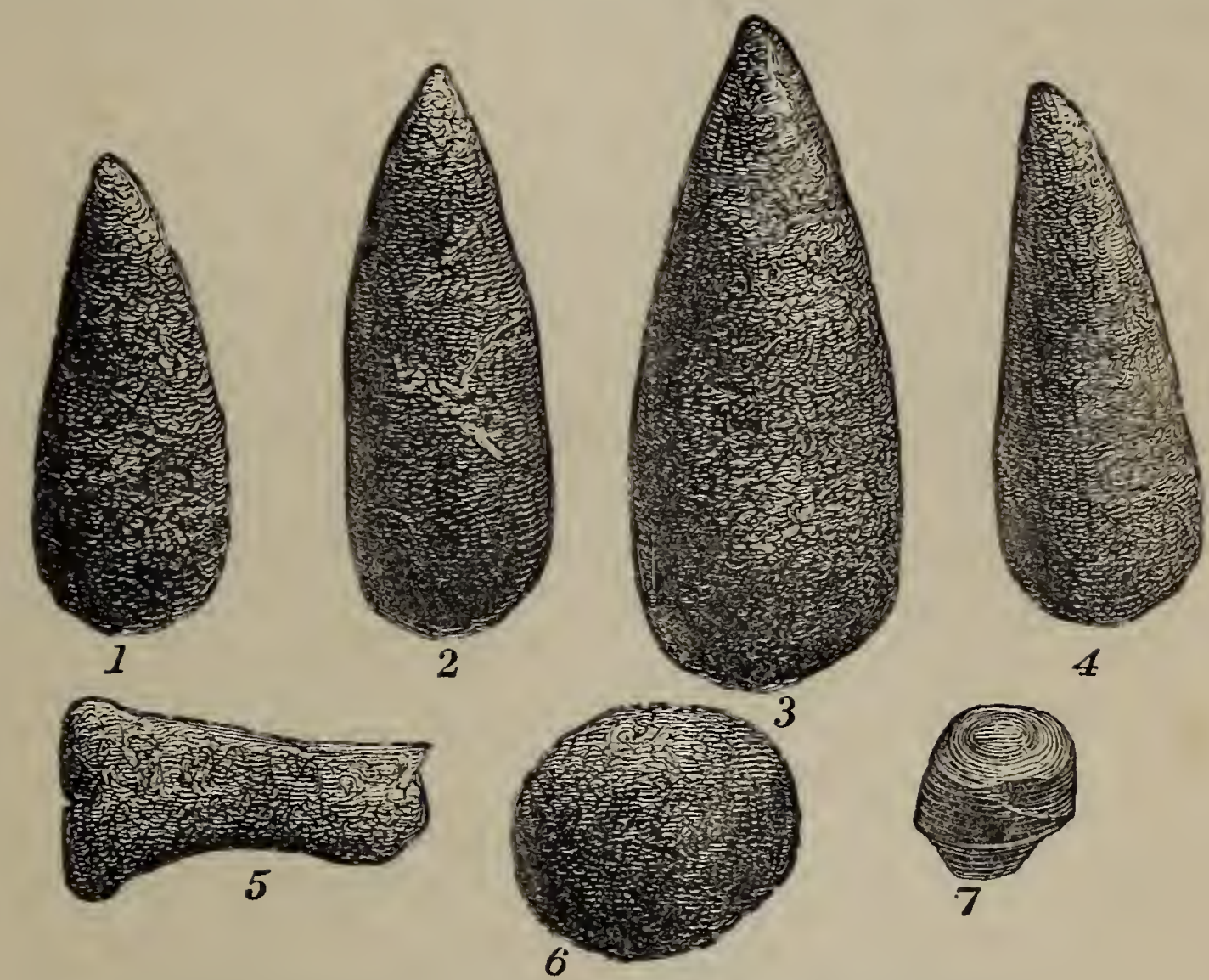

STONE IMPLEMENTS FOUND AT BOCHYM.

trict. I have attempted only to direct his attention to the points most likely to interest the geologist. For much of my information I am indebted to Mr. Henry Cox of Cadgwith, who, I doubt not, will be pleased to afford additional information to any student in geology who may happen to visit the coast.

Among the few objects of interest to the antiquarian with which I am acquainted, I may 
mention some barrows, on Goonhilly Downs, near the Dry Tree, between Gunwalloe Cove and Poljew, also on Pradanack Downs, and a circular cairn on the Rill-head. At Bochym House, on the main road from Helston to the Lizard, may be seen, by permission of the proprietor, Richard Davey, Esq., some stone implements in greenstone, sandstone, and ironstone, found in an ancient quarry near the house. 


\section{INDEX,}

Antiquities, 268.

Apron-string, the, 84.

Asbestos, 113.

Asparagus, 84, I24.

- wild, 65.

- Island, 65, 67 .

Balk, the, 108.

Bar, cutting the, $\mathbf{1} 66$.

Barnacles, 200.

Barter of fish for meat, \&c., 196.

Batha, the, 5 I.

Beast Point, 25.

Belidden, 2 I.

Bellows, the, at Kynance, 65.

Birds'-nesting, dangerous, 88.

Bishop Rock, 134 .

Blackhead, the, 28, I3I.

Boats and boatmen, xi.

Bochym, stone implements found at, 268.

Botanical adventure, perilous, 96.

Bumble, the, II.

Cadgwith, I I6, I2I.

- asparagus near, 242.

Caerleon Cove, r24.

Carn-barrow, Iog.

Cat, tailless, $5 \mathrm{I}$.

Cathedral, the, 157 .

Centenarians, 47.

Chair, the, 23.

Choughs' Hugo, I 10.

Church, divine service at Landewednack, $x$.

Church-town, 43.

Churchwardens' accounts, singular, 47.
Climbers, advice to, ro4.

Conger, conflict with, 122.

Copper-mine at Mullion, 142 ,

Cormorant, the, 75 .

Cornish giants, xi., I8o.

- heath, 2 ro.

Coverack, hotel at, xi., I2r.

Crabs and lobsters, 189.

Crenval, $5 \mathrm{r}$.

- wreck on, $5 \mathrm{I}$.

Crousa Downs, 205.

Cuckoo-fish, I8I.

Customs of the last century, 170 .

Cuttle-fish, 188.

Daws' Hugo, 13.

Degibna Wood, 175 .

Distant storm, 23.

District of leguminosæ, 209.

Dog-fish, 189.

Dollar-mine, I62.

Dolor Hugo, I 10.

Drawing-room at Kynance, the, 69.

Due Greze, 91.

Duff's Hole, 175 .

Effects of climate on vegetation, 205 .

Excursions, short, from the Lizard, xiii.

Fishery at Mullion, I $5 \mathrm{I}$.

Fishing at Kennack Cove, 126.

- for mackerel, 130 .

Flora of the district, 209-253.

Flora-day, 178 .

Font in Landewednack Church, 45 . 
French ship, 198.

Frying-pan, the, I I3.

Furry, the, at Helston, 178.

Gannet, the, 75.

Geological features of coast, 202.

- sketch of coast, 263.

Gilpin's description of Cornwall, I.

Goonhilly, I I 7 .

Grade Church, I I6.

Grampus, the, 75 .

Griffithsia, I87.

Gue Graze, 9I.

- wreck at, 105.

Guicles at the Lizard, xi.

Gull-rock, Mullion, I 36 .

Gunwalloe, 136, 160.

Gurnards, I 87.

Gweek, 3 .

Halzaphron, I63.

Helford Ferry, 3.

Helston, hotel accommodation at, ix.

- "Furry," I 78 .

Holestrow, 60.

Horse, the, 87.

Horse-pond, the, 89 .

Hotel at Coverack, I2I.

Hotels at Mullion, xi., 142.

Hot Point, 28.

Househole, I 7 .

Innis Vean, 59, 6I.

Irns at the Lizard, xi.

International Code of Signals, 26.

John MCTntyre, wreck of, 105.

Kennack Cove, fishing at, I26.

- sands, 28.

Kilkobben, 30.

Kitchen, the, at Kynance, 65.

Kynance, calm at, $7 \mathrm{I}$.

- refreshments at, xi.
Kynance, storm at, 70 .

Kynance Cove, Borlase's description of, $6 \mathrm{I}$.

- present condition of, 64 .

Landewednack, singular custom at, 48 .

Church, 43 ; doorway in, 44

Launce, or sand eel, I9.

Leguminosæ, abundance of, 210.

Lifeboats, 53 .

Ling, large, 195.

Lion Rock, 59.

Lions' Den, I4.

Little Lizard, 58.

Lizard Cove, 3 I.

- Lights, 5 .

- town, 46 .

- wood, 6.

Lobsters and crabs, I89, I93. Lodging-houses at Lizard, xi. Loe Bar, I66.

Mackerel-fishing, I 30.

Maine-Amber Rock, I 76.

Man-of-War Rocks, 57.

Marianna, wreck of, 9 .

Meneage, 3.

Minerals, 203-205.

Most southerly point in England, 50.

Mullion, inns at, xi., I42.

- Church, I44.

- Cove, I39, I40.

- Gull-rock, I 36.

- Island, I38.

Oaks, one-sided, 207.

Old Lizard Head, 59

Old windmill, $\mathrm{xv}$.

Omnibuses to and from Lizard, ix.

One-sided oaks, 207.

Ornithology, $253-263$. 
Parlour, the, at Kynance, 69.

Penballo, r Io.

Pen Olver, 17, 23.

Penrose, I68.

Penvoose, 3I.

Perilous botanical adventure, 96 .

Pigeon Hugo, 90.

Pilchard fishery, $3 \mathrm{I}$.

Pipers, I87.

Pistol Meadow, 57.

Polbero Cove, Io9.

Poljew, I 58.

Polpeer, $3 \mathrm{I}$.

- cave at, 52-56.

- lifeboat at, 53 .

Poltesco, 124.

Polybius Henslowii, I86.

Porpoises, 75.

Porthleven, I 35 .

"Post Office," the, at Kynance, 66.

Postal arrangements, $\mathrm{x}$.

Pradanack Cross, 143.

- Head, I32.

Raffino, wreck of, 9 .

Rame Head, 28.

Ravens' Hugo, Iog.

Red mullet, I28.

Refreshments at Kynance, xi.

Rill, the, 83.

Routes to the Lizard, ix.

Ruan Minor, II6 ; ancient cus. tom in, 47.

- Major, I I6.

St. Ruan's well, I I9.

Saint Rumon, I 16.

Sea, a day at, I 79 .

- bathing, I82.

- fishing, I8I, etc.

- fog, 92 .
Seaside graves, I65.

Serpentine, effect of air on, 79.

Sheep-stealers' Cave, 8I, 94.

Signal Station on Beast Point, 25.

Signals, International Code of, 27.

Smuggling, 146.

Snake pipe-fish, I84.

Soap-rock, the, 93.

Spanish electric cable, $2 \mathrm{I}$.

Stags, the, 8, 31.

Stone implements found at Bochym, 268.

Store-pot for crabs and lobsters, 200.

Sunfish, I 22.

Superstition, ancient, 58 .

Swimming.crabs, 185 .

Tamarisk tree, 44.

Tar Box, 59.

Tor Balk, 59 .

Tregonning Hill, 202.

Tregothnan, 2.

Trewavas Head, I34.

Vellan Point, I 32.

Weever, the Lesser, I 28.

Wrasse, I 8 I.

Wreck at Man-of-War Rocks, 57.

- at Poljew, I 56.

- of the Achilles, 156.

- of the Johnkheer, I 53.

- of the John Mc Intyre, 105.

- of the Jose Oscar, 154.

- of the Maria Louisa, I 55.

- on the Crenval, 5 I.

Yellow Caiin, 60.

Ynys Head, I 5 I. 
LONDON :

WYAT AND SONS, PRINTERS, GREAT QUEEN STREET, LINCOLN'S-INX FIELDS, HOC. 


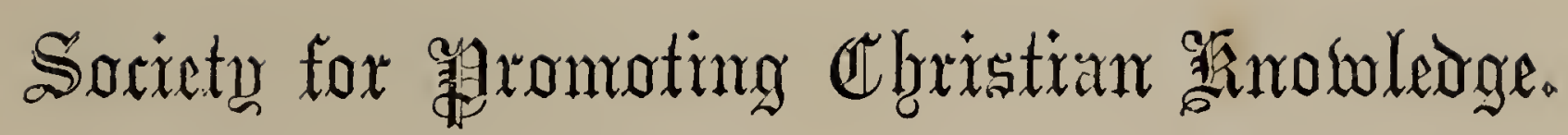

\section{NATURAL HISTORY RAMBLES.}

Fcap. 8vo., Illustrated, Cloth boards, 2s. 6d. each.

\section{LAKES AND RIVERS.}

By C. O. Groom Napier, F.G.S., Author of "The Food, Use, and Beauty of British Birds," \&c., \&c.

\section{LANE AND FIELD.}

By the Rev. J. G. Wood, M.A., Author of "Homes without Hands," \&c., \&c.

\section{MOUNTAIN AND MOOR.}

By J. E. TAYlor, F.L.S., F.G.S., Editor of "Science-Gossip."

\section{THE SEA-SHORE.}

By Professor P. Martin Duncan, M.B. (London), F.R.S.,

Honorary Fellow of King's College, London.

\section{THE WOODLANDS.}

By M. C. Coore, M.A., LL.D.

\section{U N D E R G R O UN D.}

By J. E. TAYlor, F.L.S., F.G.S., Editor of "Science-Gossip." 
Beauty in Common Things. Illustrated by 12 Drawings from Nature, by Mrs. J. W. Whymper, and printed in Colours, with descriptions by the Author of

"Life Underground," \&c. 4to.

s. $d$.

Botanical Rambles. By the late Rev. C. A. Johns,

B.A., F.L.S. With illustrations and woodcuts. Royal I 6 mo.......................................... Cloth board's

British Aninals. With I 2 coloured plates. I6mo. Ornamental covers

Birds of the Sea-shore. With I 2 coloured plates. $\mathrm{I} 8 \mathrm{mo}$..........................................Cloth boaris

Forest Trees (The) of Great Britain. By the Rev. C. A. Johss, B.A., F.L.S. New Edition. With I 50 woodcuts. Post Svo. ........... Cloth boarits

Natural History of the Bible (The). By the Rev. Canon TRISTRAMr, Author of "The Land of Israel," \&c. With numerous illustrations. Crown 8vo. Cloth boaris

Animal Creation (The). A popular Introduction to Zoology. By Thomas Rymer Jones, F.R.S. With 488 woodcuts. Post Sro. .............. Cloth boards

Lessons from the Animal World. By CHARLES and Sarah Tomlinson. With 162 woodcuts, in two volumes. Fcap. Svo. ..................... Cloth board's

Birds' Nests and Eggs. With 22 coloured plates of Eggs. Square $\mathrm{I} 6 \mathrm{mo}$. .................... Cloth boards

British Birds in their Hannts. By the late Rev. C. A. Johss, B.A., F.L.S. With 190 engravings by Wolf and Whymper. Post Sro. ........ Cloth baards ro o 


\section{$(3)$}

Flowers of the Ficld. By the late Rev. C. A. s. d. Johns, B.A., F.L.S. With numerous woodcuts. Fcap. 8vo................................. Cloth boards

Wild Flowers. By Anne Prat", Author of "Our Native Songsters," \&c. With 192 coloured plates, in two volumes. I6mo. ..........................Cloth boards

Evenings at the Microscope; or, Researches among the Minuter Organs and Forms of Animal Life. By P. H. Gosse, F.R.S. A new Edition revised and annotated. With II 2 woodcuts. Post 8vo. ...Clot/ boards

Familiar History of British Fishes. By Frank BuCKLAND, Inspector of Salmon Fisheries for England and Wales. With a Frontispiece and 134 woodcuts. Crown 8vo. ................................. Cloth boards

Natural History (Illustrated Sketches of): consisting of Descriptions and Engravings of Animals. With numerous woodcuts, in 2 vols. Fcap. 8vo.

Series I. and II. ................ Cloth boards, each Vol.

Our Native Songsiers. By Anne Pratt, Author of "Wild Flowers." With 72 coloured plates. $16 \mathrm{mo}$. Cloth boards

Selborne (The Natural History of). By the Rev. Gilbert White. With Frontispiece, Map, and 50 woodcuts. Post 8 vo. ............................Cloth boards

Ocean (The). By Philip Henry Gosse, F.R.S., Author of "Evenings at the Microscope." With $5^{\mathrm{I}}$ illustrations and woodcuts. Post 8vo. Cloth boards

Deze.drop and the Mist (The): an Account of the Phenomena and Properties of Atmospheric Vapour in various Parts of the World. By C. Tomlinson, F.C.S. With woodcuts and diagrams. Fcap. 8vo. ... Cloth boards 
Frozen Stream (The): an Account of the Fornation s. $d$. and Properties of Ice in various Parts of the World. By Charles Tomlinson. With woodcuts and diagrams. Fcap. Sro. ..........................Cloth boards

Rain-Cloud and Snow-Storm: an Account of the Nature, Formation, Properties, Dangers, and Uses of Rain and Snow. By C. ToMLinsox. With numerous woodcuts and diagrams. Fcap. Sro. Cloth boards

Tempest (The): an Account of the Origin and Phenomena of Wind in various Parts of the TVorld. By Charles Tomlinsox. With numerous woodcuts and diagrams. Fcap. 8ro. .....................Cloth boards

Thunder-Storm (The): an Account of the Properties of Lightning and of Atmospheric Electricity in various Parts of the World. By CHARLES TomLinson. With numerous woodcuts and diagrams. Fcap. 8vo. Cloth boards

Winter in the Arctic Regions and Summer in the Antarctic Regions. By Charles Tomlinson. With two maps, and several illustrations and woodcuts. Crown Sro. Cloth boards

\section{国epositorís:}

77, GRFAT QUEEN STREET, LINCOLN'S-INN FIELDS, W.C. ; 4, ROYAl exeilange, E.C.; AND 48, piccadiliy, W., LONDON. 


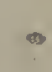

.

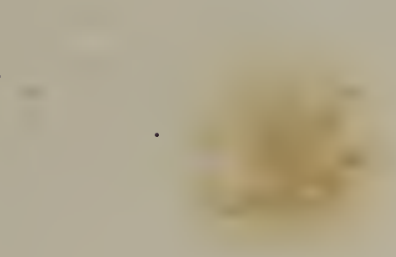

+

.

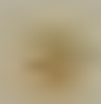

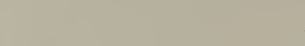




sing
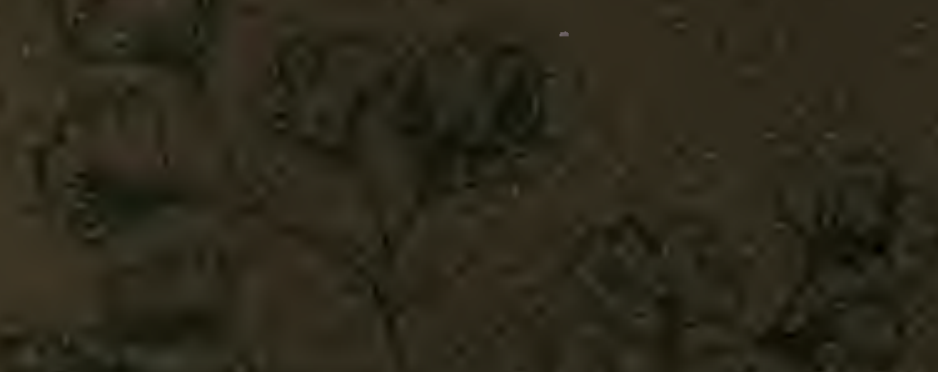

$\log ^{2+2}+2=$

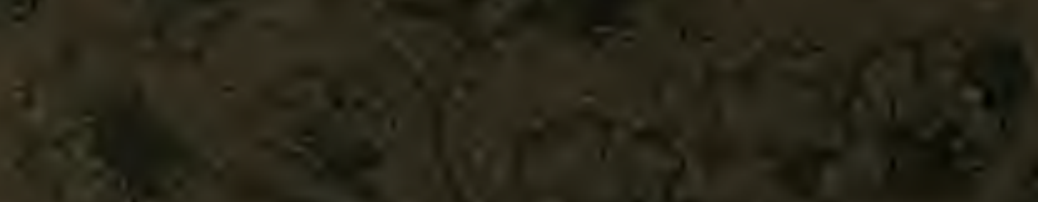$$
5
$$$$
6 x^{2}=4+2=2
$$

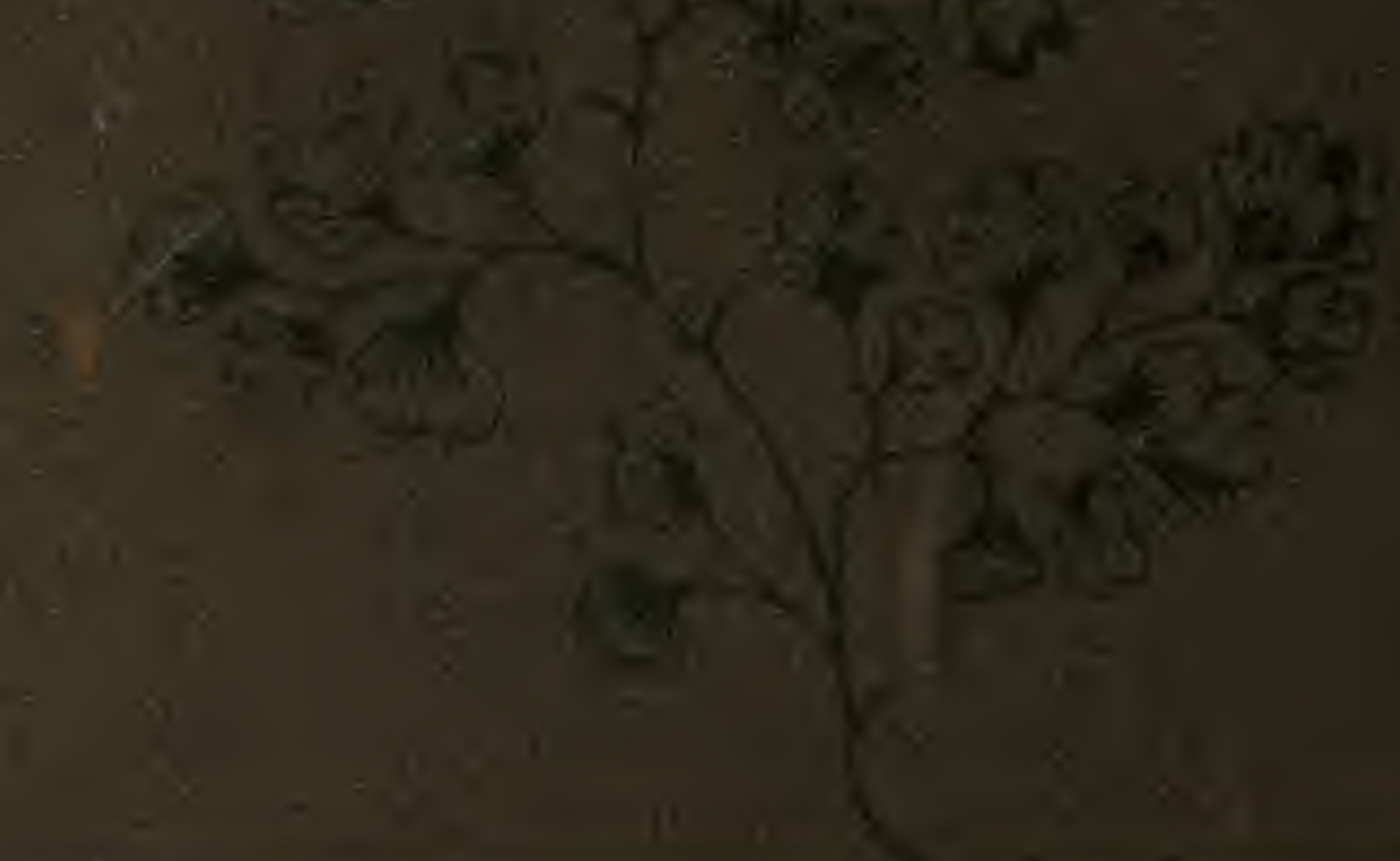

